Editora Poisson

\title{
Geografia no Século XXI Volume 3
}

\author{
1a Edição
}

Belo Horizonte

Poisson

2019 
Editor Chefe: Dr. Darly Fernando Andrade

\section{Conselho Editorial}

Dr. Antônio Artur de Souza - Universidade Federal de Minas Gerais

Msc. Davilson Eduardo Andrade

Msc. Fabiane dos Santos Toledo

Dr. José Eduardo Ferreira Lopes - Universidade Federal de Uberlândia

Dr. Otaviano Francisco Neves - Pontifícia Universidade Católica de Minas

Gerais

Dr. Luiz Cláudio de Lima - Universidade FUMEC

Dr. Nelson Ferreira Filho - Faculdades Kennedy

Msc. Valdiney Alves de Oliveira - Universidade Federal de Uberlândia

Dados Internacionais de Catalogação na Publicação (CIP) G345

Geografia no Século XXI - Volume 3/

Organização: Fabiane dos Santos

Belo Horizonte - MG: Poisson, 2019

Formato: PDF

ISBN: $978-85-7042-140-1$

DOI : $10.36229 / 978-85-7042-140-1$

Modo de acesso: World Wide Web

Inclui bibliografia

1. Meio ambiente 2. Gestão. 3. Espaço

Urbano I. dos Santos, Fabiane

CDD-577

O conteúdo dos artigos e seus dados em sua forma, correção e confiabilidade são de responsabilidade exclusiva dos seus respectivos autores.

Baixe outros títulos gratuitamente em www.poisson.com.br

contato@poisson.com.br 


\section{SUMÁRIO}

Capítulo 1: Políticas de desenvolvimento econômico para o Nordeste: Do GTDN à PNDR.

Simone da Silva Costa

DOI: 10.36229/978-85-7042-140-1.CAP.01

Capítulo 2: Aula de campo em Vila Bela da Santíssima Trindade/MT: a visita técnica e a educação como prática interdisciplinar

Paulo Daniel Curti de Almeida, Thiago Rafael da Costa Santos

DOI: 10.36229/978-85-7042-140-1.CAP.02

Capítulo 3: 0 brejo paraibano a partir de uma perspectiva de aula de campo interdisciplinar.

Isadora Duarte da Silva, Sibele Guilhermino Damázio

DoI: 10.36229/978-85-7042-140-1.CAP.03

Capítulo 4: As potencialidades da literatura como objeto de pesquisa para a geografia: Novos caminhos por vertentes ficcionais

Marcele Lima de Oliveira, Sharlene da Silva Bernardino, Maria Aletheia Stedile Belizário

DOI: 10.36229/978-85-7042-140-1.CAP.04

Capítulo 5: Localización y especialización productiva: el caso de la región amazorinoquia de Colombia 40

Cristian Orlando Avila Quiñones, Wainesten Camargo, Nilton Marques de Oliveira

DOI: 10.36229/978-85-7042-140-1.CAP.05

Capítulo 6: A migração venezuelana para o Brasil: Uma breve análise geográfica. .... 54 Ygor Felipe Távora da Silva, Antonio Jorge Barbosa da Silva

DOI: 10.36229/978-85-7042-140-1.CAP.06

Capítulo 7: Reflexões sobre os objetivos de desenvolvimento sustentável sob a ótica do empoderamento feminino indígena no médio e submédio São Francisco BA

Gisele das Chagas Costa, Regina Celeste de Almeida Souza

DOI: 10.36229/978-85-7042-140-1.CAP.07 


\section{SUMÁRIO}

Capítulo 8: A produção e a estocagem das sementes da paixão como forma de resistência ao modelo capitalista na produção agrícola: 0 caso do assentamento Três Irmãos - Triunfo, PB

Juliano Moreira do Nascimento

DOI: 10.36229/978-85-7042-140-1.CAP.08

Capítulo 9: Mutirões: 0 trabalho nos bastidores da Folia de Santos Reis em Pirenópolis, Goiás.

Maria Cristina Campos Ribeiro, Maria Idelma Vieira D’abadia

DOI: 10.36229/978-85-7042-140-1.CAP.09

Capítulo 10: Produção agropecuária e as políticas públicas na comunidade rural de remanescentes Quilombolas, Marinheiro, em Piripiri-PI

Silvana Araújo Maciel, Raimundo Wilson Pereira dos Santos

DOI: $10.36229 / 978-85-7042-140-1 . C A P .10$

Capítulo 11: Ambulantes e camelôs de Feira de Santana (BA): Origem e consolidação 95

Alessandra Oliveira Teles

DOI: $10.36229 / 978-85-7042-140-1 . C A P .11$

Capítulo 12: A segregação socioespacial do bairro Nova Caicó: refletindo sobre os espaços opacos Caicoenses

Iapony Rodrigues Galvão, Djalma Amâncio da Silva Neto, Lucas Henrique Lima Alves, Ricardo Araújo de Lemos

DOI: 10.36229/978-85-7042-140-1.CAP.12

Capítulo 13: Posições do cavado equatorial e da faixa de máxima TSM no Atlântico Tropical.

Jamilly Leite Dias, José Ivaldo Barbosa de Brito

DOI: 10.36229/978-85-7042-140-1.CAP.13 


\section{SUMÁRIO}

Capítulo 14: A influência do uso do solo no conforto humano: Uma perspectiva urbana e rural em Caicó, município de clima semiarido quente do Nordeste Brasileiro.

Artur Ismael Viana de Medeiros, Cristiano Saulo de Morais, Aline Soares da Silva, Raila Mariz Faria, Rebecca Luna Lucena

DOI: 10.36229/978-85-7042-140-1.CAP.14

Capítulo 15: *Dinâmica de uso e a pseudo recuperação hidroambiental da subbacia hidrográfica do Rio Caatinga do Moura no Sertão da Bahia

Janiel Lopes de Oliveira

DOI: $10.36229 / 978-85-7042-140-1 . C A P .15$

Capítulo 16: Monitoramento da poluição atmosférica urbana: A relação entre as concentrações de $\mathrm{CO} 2$ e temperatura do ar na Avenida Treze de Maio, Fortaleza $\mathrm{CE}$

Cristóvão Gomes, Michael Lima Silva, Adeildo Cabral da Silva

DOI: $10.36229 / 978-85-7042-140-1 . C A P .16$

Capítulo 17: Análise dos elementos climatológicos e casos de enchentes como forma de compreender a proliferação do mosquito Aedes Aegypti: 0 caso do perímetro urbano de Marabá-Pará.

Athos Ricardo Souza Lopes, Marley Trajano Lima, Gustavo da Silva

DOI: $10.36229 / 978-85-7042-140-1 . C A P .17$

Autores: 


\section{Capítulo 1}

\section{Políticas de desenvolvimento econômico para o Nordeste: Do GTDN à PNDR.}

\section{Simone da Silva Costa}

Resumo: 0 presente estudo, apresentado no XVIII Encontro Nacional da ENANPUR, realizado na cidade do Natal (RN), objetiva refletir sobre os impactos das políticas públicas no desenvolvimento do Nordeste brasileiro e que foram responsáveis pela transformação de suas estruturas produtivas ao longo do século XX, bem como compreender como as políticas atuais podem contribuir para alavancar uma nova etapa de prosperidade. Durante o período de 1970 a 1985, a região se modernizou, apresentando um aumento do seu produto interno, com destaque para os serviços e para a indústria. Contudo, nos anos de 1990, as políticas de desenvolvimento nacional e regional foram preteridas às políticas ortodoxas de estabilização da economia, fazendo emergir políticas públicas baseadas em estratégias fragmentadas que apenas tem aprofundado o subdesenvolvimento nordestino. De fato, apesar dos esforços teóricos e políticos para industrializar o Nordeste e da formulação da Política Nacional de Desenvolvimento Regional (PNDR), no ano de 2003, a região ainda se depara com velhos problemas e novos desafios, tais como: minimizar os efeitos das secas, promover uma desconcentração industrial, já que os investimentos industriais encontram-se concentrados nos estados da Bahia, Pernambuco e do Ceará; bem como combater a guerra fiscal, que tem deteriorados as finanças dos estados mais pobres do Nordeste. Trata-se de um estudo bibliográfico baseado em dados secundários.

Palavras-chave: Políticas Públicas. SUDENE. PNDR. Brasil. Nordeste. 


\section{INTRODUÇÃO}

Na década de 1950, o tema "desenvolvimento regional" começou a ser debatido pelo governo federal. Ao comparar o Nordeste com a região mais dinâmica do país, isto é, com o Sudeste, Celso Furtado observou que o problema das secas aliado a escassez de capitais produtivos industriais, impediam qualquer tentativa de superar as desigualdades regionais no país. Assim, inevitavelmente, a economia nordestina padecia com a dependência externa, tanto inter-regional quanto internacional. Na visão de Guimarães Neto (1986), a concentração industrial na região Sudeste contribuía para a continuidade das condições do subdesenvolvimento nordestino.

Para Furtado (1992b, p.39), as teorias que procuram esclarecer o desenvolvimento econômico são "esquemas explicativos dos processos sociais em que a assimilação de novas técnicas e o consequente aumento de produtividade conduz à melhoria do bem-estar de uma população com crescente homogeneização social". Inversamente, a noção de subdesenvolvimento é resultado de situações na qual os "aumentos de produtividade e assimilação de novas técnicas não conduzem à homogeneização social, ainda que causem a elevação no nível de vida médio da população" (FURTADO, 1992b, p. 39-40).

o governo de Juscelino Kubistchek, em 1956, implantou o Plano de Metas visando materializar a estratégia de substituição de importações proposta por Vargas, em seu primeiro mandato, bem como eliminar os pontos de estrangulamento na economia. Para o governo federal era imprescindível consolidar uma base industrial por meio do planejamento estatal a fim de alavancar o desenvolvimento econômico nacional. Em outras palavras, a superação do atraso econômico brasileiro "não se daria ao impulso das simples forças do mercado, exigindo um projeto político apoiado na mobilização de recursos sociais" (FURTADO, 1992a, p. 74-75).

Neste mesmo ano, as ações voltadas para o desenvolvimento regional ganharam impulso com a criação do Grupo de Trabalho para o Desenvolvimento do Nordeste (GTDN). Após um amplo diagnóstico sobre o Nordeste, elaborou-se o documento denominado de "Uma Política de Desenvolvimento Econômico para o Nordeste". A principal proposta do GTDN era industrializar a referida região implementando a indústria de base.

Em 1959, sob a direção de Celso Furtado, foi criada a Superintendência do Desenvolvimento do Nordeste (SUDENE), através da Lei n.․ 3.692, como fruto da proposta do GTDN. Esta instituição consolidou-se como uma importante experiência de planejamento regional no país. No entanto, para que as políticas implementadas tivessem êxito, era necessário combater os interesses das velhas oligarquias agrárias que dominavam na região. Isto significava a construção de "um Estado reformista, desenvolvimentista e que atuasse articuladamente no Nordeste" (ARAÚJO, 2000, p. 158).

A SUDENE foi criada sob influência das teorias elaboradas pela Comissão Econômica para a América Latina (CEPAL), cuja metodologia de pesquisa consistia no método histórico dedutivo com bases no estruturalismo. 0 objetivo principal da comissão era "analisar a inserção internacional e os condicionantes internos (as estruturas) das economias nacionais, a partir de uma concepção que opõe economias centrais e periféricas" (Fusfeld, 2003, p. 291). A terminologia centro-periferia procura esclarecer os motivos que levam ao desenvolvimento desigual do capitalismo em escala global, dividindo o mundo em países desenvolvidos (centro; industrialização avançada) e subdesenvolvidos (periferia; primário-exportador).

Segundo Prebisch (1949), nos países centrais há uma maior compatibilidade entre a absorção da tecnologia tanto nas áreas agrícolas como no âmbito das manufaturas, tendo em vista suas respectivas mão-de-obra e demanda produtiva. Isto é, há uma ampla generalização da produtividade no processo de acumulação capitalista. Já na periferia, a tendência é que a produção seja baseada na agricultura para exportação, e que tanto a tecnologia quanto a mão-de-obra especializada sejam escassas. Enquanto no centro se dissemina a penetração das técnicas capitalistas de produção, na periferia a produção permanece inicialmente atrasada, do ponto de vista tecnológico e organizativo.

Neste contexto, o principal atributo da periferia ou das regiões subdesenvolvidas consiste no desequilibro entre o progresso técnico e a produção local: "a CEPAL procurou demonstrar que a difusão internacional do progresso técnico e de seus benefícios teria ocorrido de modo diferenciado entre os países do centro (de industrialização avançada) e da periferia primário-exportadores)" (PELLEGRINO, 2005, p. 82). 
Na periferia, o progresso técnico penetra unicamente onde se faz necessário para produzir alimentos e matérias-primas a custo baixo, com destino aos grandes centros industrializados. Ou seja, naquele período histórico, a periferia produzia e fornecia bens primários baratos para os países centrais que estavam lutando por sua industrialização. Posteriormente, estes países exportavam seus produtos industrializados, de maior valor agregado, para os países periféricos (PREBISCH, 1949, p. 139).

É importante ressaltar que o objetivo da industrialização estava ocorrendo desde a década de 1930, quando o Estado vinha tentando superar o modelo econômico baseado na produção e exportação de bens primários. Portanto, dando continuidade a este objetivo, a SUDENE tinha como uma de suas principais linhas de ação: a industrialização com vistas a transformação econômica do Nordeste. Na visão de Furtado e do GTDN, o problema regional nordestino não eram as constantes secas que assolavam seus municípios, por isso, a política regional hidráulica não era a solução ideal para modificar as estruturas enraizadas na formação histórica da região. Por outro lado, os investimentos industriais também não conseguiram abranger todos os estados nordestinos, mas ficaram concentrados na Bahia, em Pernambuco e no Ceará.

\section{A CONSOLIDAÇÃO DO PLANEJAMENTO REGIONAL E A SUDENE.}

A concepção da SUDENE surgiu num período de grande insatisfação popular para com a política econômica e social até então predominante no país. A grave seca ocorrida no ano de 1958 e o fortalecimento das Ligas Camponesas colaboravam para o aumento da oposição ao Governo Central. 0 atraso econômico e os problemas sociais da região Nordeste, estavam fazendo emergir uma situação que ameaçava a "manutenção do padrão de integração do sistema político e social nacional” (COHN, 1976, p. 64).

Para Cohn (1976), o crescimento dos grupos descontentes estava promovendo grandes tensões sociais, pondo em risco a estabilidade política brasileira. Esta realidade levou as elites dirigentes do país a tentarem encontrar alternativas capazes de, pelo menos, suprir as reivindicações mínimas e controlar esses grupos de tensões. As Ligas Camponesas, lideradas por Francisco Julião, conscientizavam as massas populares quanto aos seus direitos, exigindo que o Nordeste tivesse tratamento semelhante ao que era dado às demais regiões. A insatisfação era justificada na medida em que o Centro-Sul apresentava um nível de renda bastante superior ao verificado na Região Nordeste. Naquele período, a renda per capita do Nordeste foi equivalente a somente $36,3 \%$ da renda do Centro-Sul (ver figura 1).

FIGURA 1 - RENDA DAS PRINCIPAIS REGIÕES DO PAÍS (1956) - (milhões de US\$)

\begin{tabular}{|c|c|c|}
\hline REGIÃO & RENDA TOTAL & RENDA PER CAPITA \\
\hline Norte & 440,90 & 111,00 \\
\hline Nordeste & $1.802,50$ & 96,00 \\
\hline Centro-Sul & $11.232,80$ & 303,00 \\
\hline Brasil & $13.476,20$ & 224,00 \\
\hline
\end{tabular}

Fonte: VERAS (1993, p. 135).

Os dados, por si só, já evidenciavam a necessidade de políticas públicas para a região. De acordo com o GTDN, a disparidade de renda existente entre o Nordeste e o Centro-Sul era maior que a diferença de renda entre o Centro-Sul e a média dos países industrializados da Europa Ocidental. Este baixo nível da renda era consequência "da escassez relativa do fator terra e da menor acumulação de capital" (GTDN, 1959, p. 17).

Sendo assim, a criação da SUDENE tinha um duplo objetivo: promover a modernização econômica nordestina e promover a estabilidade política da região. Contudo, por contrariar interesses das forças políticas nordestinas que estavam no Congresso, o Projeto de Lei de sua criação ocorreu às custas de intensa batalha. A lei foi aprovada "contra a maioria das bancadas nordestinas, graças ao apoio dos deputados do Centro-Sul” (FURTADO, 1989, p. 80) 
A política de Furtado consistiu na estruturação de um projeto baseado num sistema de incentivos capaz de tornar a região mais viável e atrativa para o processo de industrialização. Segundo ele, a criação de indústrias agiria no sentido de aumentar a produtividade, permitindo a formação de uma poupança própria capaz de substituir o capital estrangeiro e reduzir a dependência externa. Essa independência permitiria que o Nordeste fosse beneficiado com um crescimento interno autônomo.

Os incentivos fiscais e financeiros, inicialmente conhecidos com 34/18, previam a isenção e o reinvestimento do imposto de renda para capitalização de empresas instaladas no Nordeste; a isenção do imposto de importação de equipamentos (quando não similares aos de fabricação nacional) e a isenção do imposto sobre produtos industrializados (IPI). Em 1974, o sistema 34/18 foi transformado no Fundo de Investimentos do Nordeste (FINOR).

Os recursos públicos destinavam-se ao setor manufatureiro, objetivando "primeiro, reorganizar as indústrias da região. Em seguida, modificar a estrutura do sistema industrial, com a instalação de indústrias de base, criando, assim, um sistema capaz de auto propagação" (GTDN, 1959, p. 57-58). Já os investimentos direcionados ao setor agrícola, tinham por finalidade promover a oferta adequada de alimentos para os centros urbanos que estavam se industrializando.

As políticas públicas adotadas pretendiam promover o deslocamento da fronteira agrícola, dando destaque para a região úmida e fértil do Maranhão, até então pouco explorada. Além disso, foram elaboradas ações de combate às secas (que assolaram a atividade agropecuária na década de 1950) por meio de obras de irrigação, como a construção de açudes. É importante destacar que a política implementada pela SUDENE na região Nordeste contribuiu decisivamente, na década de 1960, para o crescimento tanto do produto total quanto do produto industrial (GTDN, 1959).

Entre os anos de 1961 e 1963, a Superintendência elaborou quatro planos diretores, cujas obras tinham a finalidade de melhorar a infraestrutura de transportes e energia existentes. Procurou também utilizar de forma racional e eficiente os recursos hídricos e minerais; modernizar, reorganizar e reestruturar o parque agrícola existente; bem como incentivar o fortalecimento da indústria tradicional (têxtil) e a implantação de novas indústrias (sobretudo as de base - bens intermediários e bens de consumo). Entretanto, com o golpe militar de 1964, Furtado teve seus direitos políticos cassados e foi exilado do país. Como resultado, o planejamento antes realizado em instância regional passou a ser pensado e executado em escala nacional (CARVALHO, 2001).

Na década de 1970, a região Nordeste começou a receber indústrias pesadas, sob o controle dos industriais privados do Centro-Sul, assumindo assim um papel complementar no conjunto da indústria nacional. A despeito do que previa o GTDN, houve um avanço rápido das indústrias oligopolistas nacionais que defendiam os interesses extra regionais. Enquanto os capitais provenientes do Centro-Sul eram aplicados na indústria de bens de consumo duráveis e de capital, os investidores nordestinos aplicavam seus recursos nas indústrias de bens de consumo não duráveis, mais simples e tradicionais (GUIMARÃES NETO e GALINDO, 1992).

Apesar da dependência do núcleo hegemônico do país, ou seja, do Centro-Sul, o processo de industrialização do Nordeste promoveu um rompimento com a estagnação verificada na década de 1950. À exceção da fase do "Milagre Econômico", em todos os demais períodos a região ou acompanhou ou apresentou um dinamismo superior à média do País.

Na figura 2, pode-se observar que o Nordeste aumentou sua participação no PIB nacional no período 1970-85, acompanhado pelas regiões Norte e Centro-Oeste. Já a região Sul ficou relativamente estável e a região Sudeste teve uma involução na participação do PIB nacional, o que mostra um período de caráter descentralizador da economia brasileira. Os dados revelam que as ações promovida pela SUDENE contribuíram para expandir o produto regional, com taxas de crescimento superiores às da economia nacional como um todo; promoveu mudanças na estrutura produtiva, com novos processos de trabalho; permitiu modificações na natureza da competição inter-regional, bem como proporcionou uma maior interdependência regional (Araújo; Souza; Lima; 1997). Somente a partir dos anos de 1980, com a interrupção das fontes de financiamento externo e a incapacidade de gerar fontes alternativas de financiamento, em virtude da crise econômica, é que as políticas públicas voltadas para o desenvolvimento do Nordeste ficaram abaladas, mas não na mesma intensidade do que ocorreu com as regiões mais dinâmicas.

"A crise afetou mais fortemente o setor industrial e, dentro dele, os segmentos produtores de bens de capital e bens de consumo duráveis. Ora, tais segmentos não têm grande presença no tecido 
industrial do Nordeste. Assim, ao se especializar mais na produção de bens intermediários, destinando parte importante às exportações, e em bens de consumo leve, a indústria recentemente instalada no Nordeste resistiu melhor aos efeitos da desaceleração da economia brasileira" (ARAÚJO, 1997, p. 159).

FIGURA 2 - PARTICIPAÇÃO DAS REGIÕES NO PIB (1970/1985) - (\%)

\begin{tabular}{|l|c|c|c|c|}
\hline \multicolumn{1}{c}{ Região } & \multicolumn{5}{c}{ Período } \\
\cline { 2 - 5 } & 1970 & 1975 & 1980 & 1985 \\
\hline Norte & 2,20 & 2,10 & 12,30 & 4,10 \\
\hline Nordeste & 11,70 & 11,10 & 62,30 & 13,70 \\
\hline Sudeste & 65,60 & 64,80 & 17,00 & 59,10 \\
\hline Sul & 16,70 & 17,90 & 5,40 & 17,10 \\
\hline Centro-Sul & $3,90 \quad 4,10$ & 6,00 \\
\hline
\end{tabular}

\section{DA SUDENE AO PLANEJAMENTO NACIONAL.}

A partir dos anos de 1970, ocorreram sucessivas transformações na forma de execução dos planos econômicos voltados para o desenvolvimento da região Nordeste. 0 planejamento regional, antes comandado pela SUDENE, foi substituído pelo planejamento nacional, resultando na descentralização espacial das inversões produtivas.

Paralelamente a estas mudanças, o Estado neoliberal estava sendo implementado em várias partes do globo, com destaque para os Estados Unidos e a Inglaterra, a fim de que a economia mundial se tornasse interdependente. A partir dos anos de 1990, tanto as regiões centrais quanto as regiões periféricas abriram suas economias, desregulamentaram seus mercados e, por conseguinte, modificaram o papel do Estado-nação. Assim sendo, o Estado abandonou o planejamento voltado para reduzir os desequilíbrios regionais e passou a agir em benefício do capital (IANNI, 2002).

Neste cenário, com os recursos da SUDENE concentrados no governo federal, tanto a Superintendência quanto outros órgãos de atuação regional, como o Banco do Nordeste do Brasil (BNB) e o Departamento Nacional de Obras Contra a Seca (DNOCS) passaram a ter papéis de meros auxiliares na política de desenvolvimento regional. $\mathrm{O}$ fortalecimento do planejamento centralizado na União "ocorreu com a fragmentação e a desarticulação do planejamento regional" (GUIMARÃES NETO, 2010, p. 352).

O I Plano Nacional de Desenvolvimento (I PND) (1972 a 1974) tinha por objetivo elevar o país a condição de "Brasil Potência". Com pouca ênfase na distribuição de renda, o propósito do plano era apoiar o capital privado nacional, concedendo empréstimos e financiamentos via "BNDE, Banco do Brasil, recursos do PASEP e Caixa Econômica Federal" (Gremaud e Pires, 2010, p. 55). É importante ressaltar que os recursos mobilizados para o desenvolvimento regional nordestino à época do I PND, dentro do Esquema 34/18, montaram cerca de US\$300 milhões em média por ano. No mesmo período, os incentivos fiscais para a Região Norte somaram aproximadamente US\$100 milhões por ano (NABUCO, 2007).

Entre 1970 e 1974, o PIB nacional cresceu em média a uma taxa de 11,4\% ao ano. A indústria, especificamente, apresentou uma taxa média anual de crescimento de $12,4 \%$ ao ano. Neste período, a região Nordeste foi contemplada com obras que procuravam modernizar a agricultura, bem como melhorar sua infraestrutura, tais como "a construção de sistemas rodoviários de interligação do Nordeste e da Amazônia e de corredores de transporte, inclusive para exportação" (Gremaud e Pires, 2010, p. 60). Nos anos de 1972 a 1974, foi implementado o Plano de Desenvolvimento do Nordeste: 
"Este plano adotou como estratégia concentrar os recursos públicos em determinados espaços, nas áreas Integradas do Nordeste e nos Polos Industriais. Os territórios usados como referência para a política agrícola mencionam o tabuleiro costeiro, as serras úmidas, os vales úmidos, as áreas de culturas de xerófilas e as áreas de colonização no estado do Maranhão. 0 Plano Regional estabeleceu como prioridade o crescimento econômico, manifestando que, para reduzir o hiato econômico com o resto do País, deveria o Nordeste crescer a $10 \%$ ao ano, meta que o próprio Plano acha de difícil consecução" (SENRA, 2009, p. 57).

A dificuldade em se atingir essa meta dizia respeito a crise mundial deflagrada no ano de 1973. Apesar das dificuldades conjunturais, o governo de Ernesto Geisel implementou o II PND em dezembro de 1974, com objetivos estratégicos de expandir a base do sistema industrial e elevar o grau de inserção da economia no sistema de divisão internacional do trabalho. 0 resultado deste plano foi a "subordinação dos objetivos de estabilização às metas de longo prazo" (ALMEIDA, 2009, p. 23).

“O Brasil ainda manteve, a despeito da estagflação na maior parte dos países da OCDE, altas taxas de crescimento do PIB, a partir de um pico de 14\% em 1973 e de quase 10\% em 1976, mas às custas de um desequilíbrio crescente nas transações correntes e de uma multiplicação por três da dívida externa líquida entre 1974 e 1979" (ALMEIDA, 2004, p. 23).

Segundo NABUCO apud SENRA (2009, p. 61), no período de vigência do II PND começaram a funcionar o Fundo de Investimentos do Nordeste -FINOR, Fundo de Investimentos da Amazônia FINAM e Fundo de Investimentos Setoriais - FISET (Decreto-Lei 1.376, de 12.12.74). Enquanto o FINOR, substituto do sistema 34/18, alocou uma média de US\$ 260 milhões por ano de 1975 a 1980; o FINAM movimentou cerca de US\$ 100 milhões por ano, entre os anos de 1975 e 1980, uma média que se manteve constante nesse período.

Os resultados alcançados pelas políticas de desenvolvimento durante o I e o II PND foram diversificados quando analisados segundo as regiões do país. A política de incentivos fiscais e creditícios concedidos para a Região Norte acelerou a degradação ambiental e a concentração fundiária. Já a SUFRAMA, ao ampliar as atividades da Zona Franca de Manaus, teve uma melhor performance. O PROTERRA, por sua vez, fracassou na proposta de promover a colonização rural, conseguindo assentar apenas cerca de 6 mil famílias. Na Região CentroOeste, os programas de modernização agrícola, apoiados pelo crédito rural abundante, pelas baixas taxas de juros e pelo desenvolvimento tecnológico, obtiveram a produção de grandes safras, conseguindo promover o desenvolvimento econômico da região, com aumento da concentração fundiária (SENRA, 2009).

Em se tratando da região Nordeste, os programas de desenvolvimento agrícola não foram capazes de alcançar bons resultados socioeconômicos. Já os projetos industriais, contidos no II PND, foram responsáveis pela criação de alguns polos industriais, tais como: o Complexo Petroquímico de Camaçari (Bahia), o Complexo Cloro químico de Alagoas, o Complexo Industrial Portuário de Suape (Pernambuco), o Polo Siderúrgico do Maranhão, o Complexo Industrial de Base de Sergipe, o Complexo Agroindustrial do Médio São Francisco (Petrolina/Juazeiro), o Polo de Fruticultura Irrigada do Vale do Açu (Rio Grande do Norte) e polos turísticos. Além destes projetos, o plano elaborou medidas de reestruturação e de modernização das indústrias têxtil e calçadista nos estados do Ceará e do Rio Grande do Norte (SENRA, 2009).

Com efeito, O I e o II PND, ao realizar grandes projetos de infraestrutura econômica, bem como de complexos industriais, conseguiu ampliar a participação do Nordeste no PIB do país. As ações realizadas pelo planejamento nacional aprofundaram a inserção do Nordeste no cenário econômico nacional, conforme podemos verificar na figura 3. Os dados apresentados revelam que os Estados de Pernambuco $(20,5 \%)$, Bahia $(35,2 \%)$ e Ceará $(13,3 \%)$ foram os mais beneficiados com projetos industriais após a execução do II PND.

Outro resultado verificado no Nordeste, após a implementação dos grandes complexos de base, foi o aumento da participação do setor industrial na composição setorial do PIB nordestino e a perda 
relativa do setor agrícola (notadamente no período 1975/1980). Já o setor de serviços continuou a ser predominante, aumentando sua participação no período em questão (ver figura 4).

A partir dos anos de 1980, com o acirramento da crise interna e externa, modificou-se a forma da maneira como o Estado vinha articulando seus planos nacionais de desenvolvimento. As políticas de desenvolvimento nacional e regional foram preteridas às políticas ortodoxas de estabilização da economia. 0 receituário neoliberal comandado por instituições como as Agências Multilaterais, o FMI, o Banco Mundial e o Banco Interamericano de Desenvolvimento, contribuíram para redução no ritmo de crescimento econômico, o que causou grande impacto, particularmente nas Regiões Sudeste e Sul do País. 0 impacto destas políticas foi o acirramento da crise econômica nacional e regional, bem como o retrocesso nas políticas de desenvolvimento regional.

FIGURA 3 - NORDESTE: PARTICIPAÇÃO DAS REGIÕES NO PIB (1970/1985) - (\%)

\begin{tabular}{|c|c|c|c|}
\hline Estados & 1975 & 1980 & 1985 \\
\hline Maranhão & 6,10 & 6,80 & 6,50 \\
\hline Piauí & 3,30 & 3,50 & 3,70 \\
\hline Ceará & 11,50 & 13,30 & 13,80 \\
\hline Rio Grande do Norte & 4,90 & 5,50 & 5,40 \\
\hline Paraíba & 6,20 & 5,50 & 5,60 \\
\hline Pernambuco & 22,10 & 20,50 & 17,70 \\
\hline Alagoas & 5,70 & 5,50 & 6,50 \\
\hline Sergipe & 3,80 & 4,20 & 5,10 \\
\hline Bahia & 36,40 & 35,20 & 35,70 \\
\hline Nordeste & 100,00 & 100,00 & 100,00 \\
\hline
\end{tabular}

Fonte: SUDENE/DPG/PSE/Grupo de Contas Regionais e FIBGE apud CARVALHO, 2001, p. 79.

FIGURA 4 - NORDESTE: COMPOSIÇÃO SETORIAL DO PIB (1970/1985) - (\%)

\begin{tabular}{|c|c|c|c|}
\hline ANO & PRIMÁRIO & 27,60 & TERCIÁRIO \\
\hline 1975 & 23,90 & 29,30 & 58,50 \\
\hline 1980 & 17,20 & 27,70 & 55,60 \\
\hline 1981 & 16,70 & 29,10 & 56,60 \\
\hline 1982 & 14,30 & 32,30 & 54,50 \\
\hline 1983 & 13,20 & 31,60 & 52,10 \\
\hline 1984 & 16,30 & 30,10 & 53,70 \\
\hline
\end{tabular}

Fonte: (SUDENE apud COSTA FILHO, 2001, p. 10).

\section{CRISE ECONÔMICA E RETROCESSO NAS POLÍTICAS DE DESENVOLVIMENTO REGIONAL.}

A partir da década de 1980, inicia-se um longo período de crise econômica com graves repercussões para as políticas de desenvolvimento regional e, especialmente aquelas voltadas para dinamizar as regiões menos dinâmicas, caso do Nordeste. A Constituição Federal de 1988, estabeleceu como um dos seus objetivos fundamentais promover a redução das desigualdades sociais e regionais. Para atingir estes propósitos, a Carta Magna criou os Fundos Constitucionais de Financiamento: o Fundo Constitucional de Financiamento do Nordeste (FNE), o Fundo Constitucional de Financiamento do Centro Oeste (FCO) e Fundo Constitucional de Financiamento do Norte (FNO). Estes fundos foram regulamentados pela a Lei, no 7.827, de 27.09.1989. 
Apesar da iniciativa, a criação destes fundos não tem sido suficiente para assegurar o desenvolvimento das regiões menos dinâmicas na proporção de suas necessidades, pois com o agravamento do cenário interno, na década de 1980, o governo passou a exercer uma política fiscal e monetária amplamente restritiva, no intuito de evitar que as contas fiscais e externas continuassem a se deteriorar. Adicionado a este fato, a fragilidade do setor produtivo nacional se agravou após a abertura da economia brasileira no início dos anos de 1990.

A exigência do Fundo Monetário Internacional (FMI) para que os países em desenvolvimento, caso do Brasil, adotassem políticas ortodoxas segundo o Consenso de Washington inibia ainda mais a formulação de políticas regionais equitativas já que os gastos públicos produtivos foram cortados. Contrariamente, o patrimônio público foi privatizado na retórica de que isto diminuiria a dívida externa. Certamente que as políticas do governo federal relacionadas à promoção do desenvolvimento, após a abertura econômica, não foram positivas para o desenvolvimento das regiões mais pobres, devido a revogação de parte das isenções e dos benefícios fiscais.

"A abertura comercial vivida no início dos anos 1990 também provocou uma grave crise na Zona Franca de Manaus, cujos incentivos se apoiavam fortemente no Imposto de Importação. (...). O Plano Collor também promoveu a revogação das isenções/reduções de benefícios fiscais, inclusive no âmbito da SUDENE e da SUDAM, bem como suspendeu temporariamente os benefícios fiscais relacionados ao FINOR, FINAM e ao Fundo de Recuperação Econômica do Espírito Santo. Isso significou a paralisação de processos de implantação de novos projetos industriais na região" (SENRA, 2009, p. 75).

De acordo com (LEONCIO, 2008, p. 40, 41), durante o período desenvolvimentista, o BNDES destinava a maior parte de seus recursos para financiar os planos de desenvolvimento. Após 1990, "passou a apoiar decisivamente, e em várias dimensões, o processo de privatização de empresas públicas e a reestruturação da economia no seu novo ambiente de liberalização comercial e financeira". isto é, o banco passou a financiar o setor privado e não apenas o desenvolvimento regional. Entre as empresas privatizadas, durante os anos de 1990 a 1994, podemos citar aquelas que pertenciam aos ramos siderúrgico, petroquímico e de fertilizantes, gerando uma receita de US\$ 8,6 bilhões (BNDES, 2002).

Neste contexto, o desenvolvimento regional sob o comando do governo federal foi paulatinamente sendo substituído por ações dos governos estaduais. Os incentivos fiscais destinados a região Nordeste passaram a ser vistos, pelos gestores públicos federais, como privilégios para as empresas. De acordo com o pensamento da época, as políticas públicas formuladas para esta região deveriam se focalizar no setor de Turismo e Fruticultura irrigada. Com relação ao turismo, o governo Collor, implementou o Programa de Desenvolvimento do Turismo (PRODETUR).

0 fato é que, o abandono das políticas nacionais voltadas para a industrialização nordestina e a emergência do processo de descentralização política, em favor de estados e municípios, os estados assumiram o papel de promotor do desenvolvimento e passaram a adotar incentivos fiscais, via redução do ICMS, para atrair investimentos. Este processo deflagrou uma luta por atrair os melhores capitais privados e ficou conhecido na literatura como Guerra Fiscal. Esta guerra apenas gera maiores vantagens aos Estados mais ricos, pois estes podem renunciar a parte de suas receitas sem comprometer as finanças públicas estaduais. Este conflito se acirrou após a abertura econômica já que a mesma proporcionou um fluxo crescente de capitais internacionais em busca de oportunidades de investimento no país" (DULCI, 2002, p. 97).

Com a emergência do Estado neoliberal e do processo de internacionalização do capital, portanto, ocorreu um retrocesso na tentativa de reduzir as desigualdades regionais via políticas públicas. Com a fragilização das políticas de desenvolvimento regional, a existência dos órgãos federais que as concretiza perdeu o sentido. Logo, em 2001, o governo federal extinguiu a SUDENE e a SUDAM, as quais perderam o seu papel de inserir as regiões Nordeste e Amazônica na dinâmica Nacional. "A MP no 2.146-1 que extinguiu a SUDENE também extinguiu o FINOR e criou o Fundo de Desenvolvimento do Nordeste (FDNE), como fonte de financiamento de políticas de desenvolvimento regional, não mais lastreado no IR-PJ, mas em dotação orçamentária e nos fundos constitucionais" (SENRA, 2009, p. 125) 
Com a extinção da SUDENE, as estratégias de desenvolvimento regional ficaram sob a responsabilidade do BNB. Este banco passou a financiar, orientar, articular e fomentar o crescimento do Nordeste, desenvolvendo vários programas e criando linhas de créditos específicas a fim de auxiliar os micros e pequenos empreendedores. Com a extinção das superintendências, o governo federal passou a construir um novo arranjo institucional para promover o desenvolvimento de suas regiões.

As políticas de caráter regional deixaram de ser formuladas de modo centralizado e orgânico nos ministérios, mas passaram a ser distribuídas em diversas agências. Os instrumentos voltados para promover este desenvolvimento também ficaram dispersos em vários ministérios, tais como: Ministérios do Desenvolvimento, Meio Ambiente, Planejamento, Fazenda e Educação. As políticas centralizadas foram substituídas por programas focalizados, como o Programa Comunidade Solidária. Além disso, as políticas sociais também passaram a ganhar importância como "componente distributivo de caráter regional" (SENRA, 2009, p. 84).

"Nesse contexto, na prática, o Ministério da Integração é responsável apenas por ínfima parcela dos investimentos dirigidos para o desenvolvimento regional, principalmente por ações para as áreas de Defesa Civil e irrigação. 0 escopo geral das instituições federais de desenvolvimento regional é complementado com a extinção de SUDAM e SUDENE e do sistema de fundos fiscais, sendo substituídos pelas Agências de desenvolvimento, voltadas para promover a competitividade do setor produtivo, e os Fundos de Desenvolvimento, que não chegaram a ser operacionalizados, contribuindo para a política fiscal do Governo" (SENRA, 2009, p. 84).

Para substituir a SUDENE e a SUDAM, o governo brasileiro criou, respectivamente, a Agência de Desenvolvimento do Nordeste (ADENE) e a Agência de Desenvolvimento da Amazônia (ADA). No entanto, a ADENE e a ADA foram criadas com status de agência reguladoras, as quais estavam estritamente relacionadas com o processo de privatização e de Reforma do Estado iniciado na década de 1980. As agências reguladoras visavam apaziguar os conflitos entre os consumidores e os empresários, emergindo num período em que o Estado deixa de fornecer serviços, considerados anteriormente como essencialmente estatais, transferindo tal função ao setor privado.

Com o fim das superintendências, a emergências de programas focalizados e o acirramento da "guerra fiscal", verificou-se um total abandono para com a formulação de políticas de desenvolvimento regional no país. De fato, a cooperação entre as regiões cedeu espaço para a lógica competitiva onde cada governo lutava por atrair investimentos privados por meio dos incentivos fiscais. A concessão de renúncias fiscais prejudica os estados mais pobres, pois não podem abdicar das receitas públicas que são utilizadas para investir em serviços públicos e infraestrutura urbana.

\section{O DESENVOLVIMENTO REGIONAL NO GOVERNO LULA.}

O governo Lula (2003-2010) se propõe a realizar uma gestão compromissada com a justiça social e com o enfrentamento das desigualdades individuais, sociais e regionais historicamente presentes no país. No que diz respeito a questão regional, no ano de 2003, foi criado no âmbito do Ministério da Integração, o Programa Nacional de Desenvolvimento Regional (PNDR), que deveria ser financiado pelo Fundo Nacional de Desenvolvimento Regional (FNDR). O fundo, proveniente da arrecadação de tributos federais, como o Imposto sobre Produtos Industrializados, o Imposto sobre Operações com Bens e Prestação de Serviços e o Imposto de Renda, deveria ampliar os financiamentos voltados para o setor produtivo, bem como para as atividades de pesquisa e desenvolvimento a fim de fortalecer a base tecnológica nacional e a criar uma infraestrutura adequada para que as regiões menos dinâmicas se tornassem mais competitivas (GUMIERO, 2013).

Com a ausência de uma política nacional voltada para promover o desenvolvimento regional num cenário de intensa competitividade global, a construção da Política Nacional de Desenvolvimento Regional (PNDR) tornava-se necessária. As políticas públicas em execução consistiam em estratégias fragmentadas de desenvolvimento. Difundia-se a ideia de que "o local pode tudo" e que os investimentos produtivos seriam atraídos para as regiões que revelassem melhores e maiores vantagens comparativas de competitividade e eficiência. Como resultado, haveria um aumento na 
geração de emprego e renda, ou seja, na qualidade de vida. Contudo, tais estratégias não têm sido suficientes para promover o desenvolvimento nordestino, mas acirrado a luta dos lugares.

Essa luta dos lugares para realizar a melhor "venda da região ou da cidade", com a busca desenfreada de atratividade a novos investimentos, melhorando o "clima local dos negócios", subsidiando os custos tributários, logísticos, fundiários e salariais dos empreendimentos, tem conduzido a um preocupante comprometimento em longo prazo das finanças locais e embotado o debate das verdadeiras questões estruturais do desenvolvimento (BRANDÃO, 2003, p. 10).

Para Brandão (2003, p. 17), a ideia de que o local é capaz de "coordenar ações cooperativas e reflexões coletivas, fundadas nas relações de reciprocidade entre os membros da comunidade local", não se sustenta. Ao contrário, os problemas regionais vêm se multiplicando, colocando limites tanto na integração dos mercados como na solução dos problemas referentes a pobreza e a segregação regional e urbana. Assim, a articulação direta dos espaços dinâmicos e competitivos com o mundo global, vem enfraquecendo os laços de solidariedade com o restante do território nacional, com prejuízo para as receitas públicas dos estados mais pobres da federação.

A nova realidade global exige, portanto, a criação de uma política nacional de desenvolvimento regional que atue no sentido de evitar a desintegração nacional, por meio da inserção de recursos públicos nas áreas prioritárias para o crescimento das regiões, tais como: infraestrutura e capacidade produtiva. Neste sentido, a partir de 2003, o BNDES passou conceder mais empréstimos visando alavancar o setor produtivo nacional (ver figura 5).

FIGURA 5 - DESEMBOLSOS TOTAIS DO BNDES - 2003/2010 - (milhões de US\$)

\begin{tabular}{|c|c|}
\hline Ano & Quantidade desembolsada \\
\hline 2003 & 51,40 \\
\hline 2004 & 54,20 \\
\hline 2005 & 59,50 \\
\hline 2006 & 62,30 \\
\hline 2007 & 73,00 \\
\hline 2008 & 96,60 \\
\hline 2009 & 137,40 \\
\hline 2010 & 168,40 \\
\hline
\end{tabular}

Fonte: www.bndes.gov.br. Elaborada pelo autor.

A Política Nacional de Desenvolvimento Regional (PNDR) tão necessária ao crescimento equitativo com distribuição regional da renda surgiu no ano de 2003, com o objetivo de reduzir as desigualdades regionais e ativar as potencialidades de desenvolvimento das regiões brasileiras. Apesar de sua importância, a política encontrou muitas barreiras para a sua execução. Em 2007, a SUDENE e a SUDAM voltaram a atuar, mas não possuíam mecanismos de ação eficientes para formular e executar os planos regionais de desenvolvimento, pois a recriação das instituições não estava mais baseada no "mecanismo de incentivos fiscais. As novas superintendências deveriam promover a intervenção territorial, "tendo como objetivos a inclusão social, o desenvolvimento sustentável e a melhoria das condições de competitividade da economia regional" (COSTA, 2016, p. 147).

Apesar da formulação da PNDR e do retorno da SUDENE, as ações realizadas não têm sido suficientes para inibir a concentração e a centralização produtiva, a qual ainda se apresenta bastante elevada. Conforme mostra a figura 6, no período de 2003 a 2010, como resultado das políticas públicas adotadas pelo governo Lula, a participação do Nordeste na formação do PIB não sofreu grandes transformações. Em 2003, a participação do PIB nordestino no PIB nacional era de apenas $12,8 \%$. No ano de 2010 , este indicador subiu para $13,5 \%$ 
FIGURA 6 - BRASIL: PARTICIPAÇÃO DAS REGIÕES NO PIB (1995/2010) - (\%)

\begin{tabular}{|c|c|c|c|c|c|c|c|c|}
\hline $\begin{array}{l}\text { Unidades da } \\
\text { Federação }\end{array}$ & 1995 & 1998 & 1999 & 2002 & 2003 & 2006 & 2007 & 2010 \\
\hline Norte & 4,20 & 4,20 & 4,20 & 4,70 & 4,80 & 5,10 & 5,00 & 5,30 \\
\hline Nordeste & 12,00 & 12,40 & 12,40 & 13,00 & 12,80 & 13,10 & 13,10 & 13,50 \\
\hline Maranhão & 0,90 & 1,00 & 1,00 & 1,00 & 1,10 & 1,20 & 1,20 & 1,20 \\
\hline Piauí & 0,50 & 0,50 & 0,50 & 0,50 & 0,50 & 0,50 & 0,50 & 0,60 \\
\hline Ceará & 1,90 & 2,00 & 1,90 & 2,00 & 1,90 & 2,00 & 1,90 & 2,10 \\
\hline Rio Grande do Norte & 0,70 & 0,70 & 0,80 & 0,80 & 0,80 & 0,90 & 0,90 & 0,90 \\
\hline Paraíba & 0,70 & 0,80 & 0,80 & 0,80 & 0,80 & 0,80 & 0,80 & 0,80 \\
\hline Pernambuco & 2,30 & 2,40 & 2,30 & 2,40 & 2,30 & 2,30 & 2,30 & 2,50 \\
\hline Alagoas & 0,70 & 0,70 & 0,70 & 0,70 & 0,70 & 0,70 & 0,70 & 0,70 \\
\hline Sergipe & 0,50 & 0,60 & 0,60 & 0,60 & 0,60 & 0,60 & 0,60 & 0,60 \\
\hline Bahia & 3,70 & 3,90 & 3,90 & 4,10 & 4,00 & 4,10 & 4,10 & 4,10 \\
\hline Sudeste & 59,10 & 58,20 & 58,20 & 56,70 & 55,80 & 56,80 & 56,40 & 55,40 \\
\hline Sul & 16,20 & 16,20 & 16,40 & 16,90 & 17,70 & 16,30 & 16,60 & 16,50 \\
\hline Centro-Oeste & 8,40 & 9,00 & 8,80 & 8,80 & 9,00 & 8,70 & 8,90 & 9,30 \\
\hline
\end{tabular}

Fonte: IBGE, Contas Regionais 2010 apud BNB, 2013, p. 8.

Em se tratando da indústria, houve uma retração na participação da região Sul e da região Sudeste na atividade manufatureira do país. O Sudeste passou de 55,8\% em 2003 para 58\% em 2010. 0 Sul, por sua vez, apresentou uma queda de 18,9\% para 17,7\% no mesmo período. Já a região Nordeste, apresentou um aumento na produção industrial de apenas $0,4 \%$, passando de $11,6 \%$ no ano de 2003, para $12 \%$ no ano de 2010. A região Norte apresentou um aumento de 0,5\%, passando de 4,8\% em 2003 para 5,3\% em 2010. O Centro Oeste também apresentou um baixo crescimento industrial, passou de 4,7\% para 5,6\%, no mesmo período (ver figura 7).

Na atualidade, apesar das políticas públicas implementadas, ao longo do século XX, visando dos esforços da industrialização, as regiões brasileiras ainda apresentam várias características de uma região subdesenvolvida e periférica, tais como: fragilidade no balanço de pagamentos, elevada tributação regressiva, dificuldades de financiamentos para os investimentos produtivos de longo prazo. Além disso, a fraca intervenção do Estado na economia e a implementação das políticas neoliberais não tem contribuído para a construção de um projeto nacional de desenvolvimento (BRANDÃO, 2003).

Enfim, os problemas regionais vêm tornando-se cada vez mais complexos à medida que o governo brasileiro adota políticas econômicas de cunho ortodoxo, como a valorização cambial, os juros elevados e retração do gasto público. Os ramos industriais, de maior valor agregado, têm se voltado para o Centro - Sul, em detrimento do Nordeste, já que existem naquelas regiões uma infraestrutura mais eficiente, mão de obra mais qualificada e uma maior proximidade com os principais mercados consumidores. 
FIGURA 7 - PARTICIPAÇÃO REGIONAL E ESTADUAL (NORDESTE) NA PRODUÇÃO INDUSTRIAL NACIONAL (1995/2010) - (\%)

\begin{tabular}{|c|c|c|c|c|c|c|c|c|}
\hline Unidades da Federação & 1995 & 1998 & 1999 & 2002 & 2003 & 2006 & 2007 & 2010 \\
\hline Norte & 4,40 & 4,20 & 4,00 & 5,20 & 5,20 & 5,70 & 5,50 & 6,70 \\
\hline Nordeste & 10,00 & 11,40 & 11,50 & 12,00 & 11,60 & 11,70 & 11,60 & 12,00 \\
\hline Maranhão & 0,50 & 0,70 & 0,70 & 0,70 & 0,80 & 0,90 & 0,80 & 0,70 \\
\hline Piauí & 0,20 & 0,30 & 0,30 & 0,30 & 0,30 & 0,30 & 0,30 & 0,40 \\
\hline Ceará & 1,60 & 1,90 & 1,90 & 1,70 & 1,50 & 1,60 & 1,60 & 1,80 \\
\hline Rio Grande do Norte & 0,50 & 0,60 & 0,70 & 0,80 & 0,70 & 0,80 & 0,80 & 0,70 \\
\hline Paraíba & 0,50 & 0,60 & 0,60 & 0,80 & 0,70 & 0,70 & 0,70 & 0,70 \\
\hline Pernambuco & 2,00 & 2,00 & 2,00 & 1,90 & 1,90 & 1,80 & 1,80 & 2,00 \\
\hline Alagoas & 0,50 & 0,60 & 0,60 & 0,70 & 0,70 & 0,60 & 0,60 & 0,50 \\
\hline Sergipe & 0,50 & 0,60 & 0,60 & 0,80 & 0,80 & 0,70 & 0,70 & 0,70 \\
\hline Bahia & 3,50 & 4,00 & 4,20 & 4,40 & 4,20 & 4,30 & 4,20 & 4,50 \\
\hline Sudeste & 63,30 & 62,50 & 61,80 & 59,30 & 59,60 & 60,50 & 60,20 & 58,00 \\
\hline Sul & 18,40 & 17,70 & 18,40 & 18,70 & 18,90 & 17,30 & 17,70 & 17,70 \\
\hline Centro-Oeste & 3,80 & 4,30 & 4,20 & 4,70 & 4,70 & 4,80 & 5,00 & 5,60 \\
\hline
\end{tabular}

Fonte: IBGE, Contas Regionais 2010 apud (BNB, 2013, p. 83).

Por outro lado, a institucionalização da PNDR, no ano de 2007, não foi eficiente para reduzir as desigualdades regionais, devido à falta de recursos para viabilizar suas metas e objetivos. Sem a aprovação do Fundo Nacional de Desenvolvimento Regional (FNDR), tanto o Ministério da Integração quando as Superintendências ficaram dependentes dos fundos constitucionais e dos benefícios e incentivos fiscais já existentes. Em outras palavras, sem recursos próprios, a PNDR não tem como promover ações visando potencializar o setor produtivo de cada região ou mesmo evitar a formação de áreas de prosperidade, por meio da Integração do local ao nacional e não apenas do local ao global.

\section{CONSIDERAÇÕES FINAIS}

O trabalho apresentado procurou mostrar a importância que o planejamento regional foi para o desenvolvimento da economia nordestina desde a criação da SUDENE até a implementação da PNDR. 0 tema se justifica na medida em que, com a mudança das funções do Estado, na década de 1990, prevalecem a guerra entre os lugares com iniciativas de cada localidade para atrair investimentos privados e/ou recursos federais.

Foi verificado que, a partir dos anos de 1960, a adoção de políticas regionais efetivas, contribuíram para transformar a estrutura produtiva na região Nordeste, ainda que os investimentos industriais foram bastante concentrados nos estados da Bahia, Pernambuco e do Ceará. 0 planejamento econômico, embasado nos pressupostos teóricos da CEPAL, foi decisivo para que o Nordeste se industrializasse. Após a segunda metade da década de 1950 e o final da década de 1960, houve um crescimento do produto interno bruto e da renda per capita nordestina, mas ainda precisa melhorar bastante a fim de reduzir as elevadas desigualdades sociais presentes.

A política regional implementada pela SUDENE, de reorganizar e diversificar o setor industrial, foi alcançado de tal forma que houve um aumento na participação da produção industrial no total da produção regional, inclusive, superando a participação da produção do setor primário, no ano de 1970. Mas, com a centralização das políticas públicas centralizadas no governo federal após este período, o planejamento regional elaborado e executado pelas superintendências SUDENE e SUDAM, começaram a ter um menor impacto na transformação produtiva, em virtude da escassez de recursos para financiar seus projetos e investimentos. 
Assim, entre 1970 e 1985, as mudanças econômicas experimentadas pela região nordestina, resultaram das políticas centralizadas na esfera federal, especificamente, pelos Planos Nacionais de Desenvolvimento, que atuaram no intuito de promover a desconcentração nacional das inversões e a integração produtiva da região, articulando-a com o restante do país. Pode-se perceber que, a partir de então, verificou-se uma maior heterogeneidade produtiva no nordeste do país, dando continuidade ao crescimento da década anterior. Além disso, a economia nordestina apresentou uma maior dinâmica econômica em virtude dos polos de crescimento que estavam baseados na implantação de ramos da indústria de bens intermediários.

Tanto as políticas regionais quanto os planos de desenvolvimentos foram indispensáveis para a economia nordestina, a qual passou a apresentar uma nova configuração industrial dado o crescimento da parcela do setor líder, ou seja, o setor de bens intermediários. Esta performance foi seguida pelo setor de bens de consumo não duráveis. Entretanto, este bom desempenho foi interrompido com a crise dos anos de 1980 e a adoção de políticas neoliberais na década de 1990, quando houve mudança na forma de atuação do Estado Nacional. logo, com o fim do planejamento a nível nacional e regional, começaram a emergir plano setoriais com impactos negativos para a indústria nordestina. Adicionado a este fato, a extinção das superintendências, no ano de 2001, e o acirramento da "guerra fiscal", reduziu a cooperação entre as regiões, permitindo o acirramento da lógica competitiva, onde cada governo lutava e ainda luta para atrair investimentos privados por meio dos incentivos fiscais.

Para minimizar a guerra fiscal e as estratégias fragmentadas de desenvolvimento regional, o governo federal instituiu a PNDR, mas sem o êxito necessário para que o Nordeste supere o seu desenvolvimento, por falta de recursos públicos que financiem seus projetos. 0 maior desafio, na presente década, é minimizar a luta entre os lugares, pois, no longo prazo, tais práticas colaboram para a erosão das finanças locais e mascaram o debate das verdadeiras questões estruturais do desenvolvimento regional.

Concluindo, é necessário que o país retome as questões voltadas para o fortalecimento da industrial nacional e regional, dê continuidade às políticas sociais que contribuíram para a redução da pobreza e das desigualdades sociais, afim de construir políticas públicas voltadas para dinamizar o crescimento econômico, mas principalmente voltadas para a redução das desigualdades regionais e sociais, conforme preconizado pela Carta Magna de 1988.

\section{REFERÊNCIAS}

[1] ARAÚJO, Tânia Bacelar. O Nordeste brasileiro face à globalização: impactos iniciais, vantagens e desvantagens competitivas. In: Seminário Inserção na Economia Global: uma reapreciação. São Paulo: Centro de Estudos Konrad Adenauer Stiftung, p. 157-188, 1997.

[2] ___ Ensaios sobre o desenvolvimento brasileiro: heranças e urgências. Revan: Fase: Rio de janeiro, 2000.

[3] ARAÚJO, Tarcísio Patrício; LIMA, Roberto Alves de; SOUZA, Aldemir do Vale. Nordeste: economia e mercado de trabalho. Estudos Avançados. São Paulo, v. 11, n. 29, p. 55-77, 1997.

[4] ALMEIDA, Paulo Roberto; A experiência brasileira em planejamento econômico: uma síntese histórica. Universidade de Bruxelas. Bruxelas, 2004. Disponível em: https://celsofurtado.phlnet.com.br/artigos_scf/Paulo_Roberto_Almeida.pdf. Acesso: 16/11/2018.

[5] BNDES. Privatização no Brasil 1990-2002. Rio de Janeiro, 2002.

[6] CARVALHO, Fernanda Ferrário de. Da esperança à crise - a experiência das políticas regionais no Nordeste. Dissertação de Mestrado. São Paulo: Universidade Estadual de Campinas, 2001.

[7] BNB - Banco do Nordeste do Brasil. A Região Nordeste nas contas regionais do Brasil: 19952010. Fortaleza, 2013.

[8] BRANDÃO, Carlos Antônio. A Dimensão Espacial do Subdesenvolvimento: uma agenda para os estudos urbanos e regionais. Tese de Livre Docência. São Paulo: Universidade Estadual de Campinas, 2003.

[9] COHN, Amélia. Crise regional e planejamento (o processo de criação da SUDENE). São Paulo: editora perspectiva, 1976.

[10] COSTA FILHO, Samuel. A Necessidade de uma Nova Política Desenvolvimentista. Fortaleza: UFC/CAEN, 2001. 
[11] DULCI, Otávio Soares. Guerra Fiscal, Desenvolvimento Desigual e Relações Federativas no Brasil. Revista de Sociologia e Política. n. 18, p. 95-107, 2002.

[12] FURTADO, Celso. A Fantasia desfeita. São Paulo: Paz e Terra, 1989.

[13] ___ Brasil: a construção interrompida. Rio de Janeiro: Paz e Terra, 1992a.

[14] _. O 0 subdesenvolvimento revisitado. In: Economia e Sociedade. Campinas, 1992b, p. 5-19.

[15] FUSFELD, Daniel Roland. A Era do Economista. São Paulo: Saraiva, 2003.

[16] IANNI, Octavio. Teorias da Globalização. Rio de Janeiro: Editora Civilização, 2002.

[17] GREMAUD, Amaury Patrick e PIRES, Júlio Manuel. Metas e Bases e I Plano Nacional de Desenvolvimento (1970-1974). In: KON, Anita. Planejamento no Brasil II. São Paulo: Perspectiva, 2010.

[18] GTDN - Grupo de Trabalho para o Desenvolvimento do Nordeste. Uma política de desenvolvimento econômico para o Nordeste. Recife, 1959.

[19] GUIMARÃES NETO, Leonardo. Nordeste: da articulação comercial à integração econômica. Tese de Doutorado. São Paulo: Universidade Estadual de Campinas, 1986.

[20] _ O 0 planejamento regional no Nordeste: notas para uma avaliação. In: KON, Anita. Planejamento no Brasil II. São Paulo: Perspectiva, 2010. p. 341-386.

[21] GUIMARÃES NETO, Leonardo; GALINDO, Osmil. Quem controla o que na indústria incentivada do Nordeste. Cadernos IPPUR/UFRJ. Ano VI, n. 1, dez, 1992.

[22] GUMIERO, Rafael. O Nordeste em dois tempos: a “Operação Nordeste" e a Política de Desenvolvimento Regional no governo Lula. CEPAL - Coleção Documentos de Projeto. Santiago: Chile, 2013.

[23] LEONCIO, Lourenço. As transformações do BNDES diante do contexto atual da economia brasileira. Monografia em Ciências Econômicas. Florianópolis: - Universidade Federal de Santa Catarina, 2008.

[24] NABUCO, Maria Regina. A (des) institucionalização das políticas regionais. In Espaço, tempo e crítica, v. 1, n 2(6), v. 1. Belo Horizonte: CEDEPLAR, 2007.

[25] PELLEGRINO, Anderson César Gomes Teixeira. Nas Sombras do Subdesenvolvimento: Subdesenvolvimento e Problemática Regional em Celso Furtado. Campinas: Alínea, 2005, p. 79-136.

[26] PREBISCH, Raul. Estudo Econômico da América Latina, 1949. In: BIELSCHOWSKY, R. Cinquenta anos de pensamento da Cepal. Rio de Janeiro: Record, 2000, p. 137-178.

[27] RODRI GUEZ, Octavio. Teoria do desenvolvimento da CEPAL. Rio de Janeiro: ForenseUniversitária, 1981.

[28] SENRA, Kelson Vieira. Políticas Federais de Desenvolvimento Regional no Brasil: uma análise comparada dos Períodos Pós-Guerra (1945-1964), Pós-Golpe Militar (1964-1988) e Pós Constituição Federal de 1988 (1988-2009). Dissertação de Mestrado. Brasília: Universidade de Brasília, 2009.

[29] VERAS, Edmilson Correia. A SUDENE e o desenvolvimento agrícola do Nordeste. Tese de Doutorado. São Paulo: Universidade Estadual de Campinas, 1993. 


\section{Capítulo 2}

Aula de campo em Vila Bela da Santíssima Trindade/MT: a visita técnica e a educação como prática interdisciplinar

\section{Paulo Daniel Curti de Almeida}

Thiago Rafael da Costa Santos

Resumo: No exercício prático de sua função, o professor necessita produzir recursos capazes de viabilizar o crescimento profissional e tecnológico, motivando o aprendizado dos estudantes. Destarte, a visita técnica mostra-se um instrumento de ensino positivo, pois proporciona maior interatividade e interesse dos estudantes, pelo envolvimento dos mesmos durante a realização das atividades, pois poderão vivenciar lugares e experiências novas, que trarão novas interpretações para a sua formação. Nesse sentido, ao elaborar uma visita técnica ao município de Vila Bela da Santíssima Trindade, no extremo oeste do estado de Mato Grosso, os objetivos propostos foram: a) discutir a importância da atividade de visita técnica como instrumento facilitador da compreensão espacial, temporal e ambiental pelos discentes do Instituto Federal de Educação, Ciência e Tecnologia de Mato Grosso, campus Pontes e Lacerda-Fronteira Oeste e b) caracterizar atrativos espaciais, simbólicos-temporais e ambientais no município de Vila Bela da Santíssima Trindade-MT mensuráveis na execução de atividade de visita técnica. Deste modo, e diante das informações apresentadas, julga-se a importância da visita técnica como forma de rever os conceitos teórico-metodológicos e expressar o diálogo produzido em sala de aula, com a construção de conceitos a partir de observações feitas no desenvolvimento técnico-científico e reforçadas pelo método da visita técnica.

Palavras Chave: Visita Técnica, Geografia e História de Mato Grosso, Vila Bela da Santíssima Trindade. 


\section{INTRODUÇÃO}

O estado do Mato Grosso apresenta uma grande diversidade de situações ecológicas, fundiárias, econômicas, históricas, simbólicas, entre outras, criando possibilidades múltiplas para o estabelecimento das análises e discussões sobre diversas variáveis. Por tudo isso, acredita-se que conhecer in loco, mesmo que de forma parcial, é julgado como meio imprescindível de ampliar o conhecimento do espaço, através da estratégia denominada como visita técnica.

No exercício prático de sua função o professor necessita produzir recursos capazes de viabilizar o crescimento profissional e tecnológico, motivando o aprendizado dos estudantes. Assim, o recurso da visita técnica se enquadra como excelente instrumento de motivação e de visualização in loco daquilo que é ensinado na sala de aula.

A visita técnica como proposta pedagógica de ensino tem importância em função de seu papel investigativo e pedagógico de auxiliar o estudante na compreensão de fenômenos diversos. Destarte, a visita técnica mostra-se um instrumento de ensino positivo, pois proporciona maior interatividade e interesse dos estudantes, pelo envolvimento dos mesmos durante a realização das atividades, pois poderão vivenciar lugares e experiências novas, que trarão novas interpretações para a sua formação (PERES, 2005).

Outros apontamentos referentes à importância da aula de campo para a construção do conhecimento e o desenvolvimento do raciocínio lógico dos educandos são feitos por Carbonell (2002), que destaca que os espaços fora da sala de aula despertam a mente e a capacidade de aprender, pois se caracterizam como espaços estimulantes e que, quando bem aproveitados, se classificam como um relevante cenário para a aprendizagem. Rodrigues e Otaviano (2001) acrescentam que quando se relaciona os conteúdos vistos com a situação vivenciada na aula de campo, é construída uma forte tendência em desenvolver no aluno uma sensibilização maior ao mundo natural e cultural, além de propiciar o enriquecimento harmonioso da personalidade do aluno e a aquisição de conhecimentos de conteúdos relacionados à visita.

Nesse contexto, aceita-se as ideias de Sousa et. al (2016, p. 2), que inferem que

a atividade de campo consiste no contato direto com o ambiente de estudo fora dos muros burocráticos da sala de aula, que permite ao professor o conhecimento de um instrumento pedagógico eficiente e bastante proveitoso na relação ensino-aprendizagem. Os estudantes que participam da atividade de campo são motivados e estimulados a pensar criticamente; dessa forma, confrontam informações associando a aula teórica ao momento. Esse estímulo possibilita ao educando um motivo maior de aprender e de formar conhecimento pelo desafio do pensar crítico.

Diante das informações apresentadas, julga-se a importância da visita técnica como forma de rever os conceitos teórico-metodológicos e expressar o diálogo produzido em sala de aula, com a construção de conceitos a partir de observações feitas no desenvolvimento técnico-científico e reforçadas pelo método da visita técnica.

Sendo assim, e, diante das ressalvas colocadas anteriormente, considera-se que as visitas técnicas são de suma importância para o discente aprimorar o que tem recebido em sala de aula, construindo empiricamente através da prática a parte teórica da sala de aula.

Mas, há de se concordar com diversos autores que, nas suas contribuições sobre a importância da atividade de visita técnica como valioso recurso na aprendizagem, destacam a ação de planejamento para a execução de todas as etapas da visita técnica. Na concepção de Sousa (2014), a visita técnica não é concretizada apenas pela visita ao local pelos estudantes e professor(es). Engloba o planejamento, a delimitação dos conteúdos abordados que serão a ligação entre a teoria e a prática, elaboração de roteiros, ou seja, tudo que é pensado e elaborado antes, durante e depois da atividade são elementos fundamentais para o sucesso da visita técnica.

Nesse sentido, ao elaborar uma visita técnica ao município de Vila Bela da Santíssima Trindade, no extremo oeste do estado de Mato Grosso, os objetivos propostos foram: a) discutir a importância da atividade de visita técnica como instrumento facilitador da compreensão espacial, temporal e ambiental pelos discentes do Instituto Federal de Educação, Ciência e Tecnologia de Mato Grosso, campus Pontes e Lacerda-Fronteira Oeste e b) caracterizar atrativos espaciais, simbólicos- 
temporais e ambientais no município de Vila Bela da Santíssima Trindade-MT mensuráveis na execução de atividade de visita técnica.

\section{ATRATIVOS SOCIOESPACIAIS E SIMBÓLICOS-HISTÓRICOS NO/DO MUNICÍPIO DE VILA BELA DA SANTÍSSIMA TRINDADE-MT}

Quando em 1780 o engenheiro militar Ricardo Franco de Almeida Serra finalmente apresentou à Sua Majestade a planta-projeto da cidade de Vila Bela da Santíssima Trindade, então capital da antiga Província de Mato Grosso, o engenheiro certamente estava consciente de que havia concluído mais uma etapa no xadrez de um longo jogo político. Sabia também que seu desenho, que pretendia disciplinar o ordenamento urbano da vila, coroava de maneira inequívoca um processo de ocupação e domínio territorial que naquele momento já durava bem mais de meio século.

Em realidade, desde os desdobramentos da "guerra dos emboabas" na região das Minas Gerais e o subsequente redirecionamento do avanço dos paulistas para o centro-oeste da colônia, no começo do século XVIII, que a corte manifestava uma viva atenção às terras que serviam de limite às possessões portuguesas e espanholas na América, em uma linha que partia da Colônia do Sacramento ao Grão-Pará. Já em 1720, de acordo com Otávio Canavarros, "quando surgiram em Lisboa as notícias dos primeiros achados do ouro, insistia D. João $\mathrm{V}$ em fundar ali uma vila com o claro objetivo de conter a expansão castelhana (jesuítica ou de colonos) para Leste" (CANAVARROS, 2004, p. 47). Não era por menos. Em 1717 chegaram em Portugal informações do encontro de sertanistas paulistas com padres espanhóis no sertão. Embora à época a definição de "sertão" seja tão imprecisa como polissêmica (Russell-Wood, 2014), não há dúvidas que se tratava de terras interiores, cuja soberania era igualmente incerta. No final de 1719 descobria-se ouro nos arredores da área que mais tarde viria a ser nomeada de Cuiabá, o que faz com que d João V, um ano mais tarde, solicite "pela segunda vez" ao governador-general de São Paulo, Rodrigo César de Menezes, que fundasse ali uma vila. Em 1723 o rei apela novamente ao governador-general, que somente em "novembro de 1726, chegava às novas lavras [...] com uma numerosa comitiva de 3.000 pessoas" (CANAVARROS, 2004, p. 47). Em 1727 fundava-se a Vila do Goiás, que junto com a de Cuiabá, estava vinculada à capitania de São Paulo. 0 objetivo era claro: traçar uma linha de comunicação e abastecimento que ligasse os territórios litorâneos - mais populosos e de fácil acesso - aos sertões interiores. Para Canavarros, "A preocupação de D. João V não se esgotava no ouro, procurando, além deste, configurar as bases territoriais do Império e esboçar uma política de segurança" para toda a região (idem, p. 58).

Compreende-se, pois, a planta da cidade de Vila Bela como um movimento triunfal dentro desse intricado jogo político, no qual os anseios de preservação das fronteiras para deste modo assegurar o domínio dos territórios, bem como a manutenção da exploração aurífera, confundiam-se em um longo planejamento régio. A constituição de um núcleo urbano habitado por agentes lusobrasileiros no ponto mais avançado no oeste da colônia era não apenas fundamental, mas imprescindível para a realização dos planos da Coroa. Assim, o desenho da cidade - elaborada por Ricardo Franco três décadas após a fundação da Vila - devia servir enquanto instrumento para a legitimação de sua posse.

A capitania de Mato Grosso foi criada em 09 de maio de 1748, desmembrando-se da capitania de São Paulo. Dom Antônio Rolim de Moura foi o primeiro governador da província, chegou em Cuiabá em 12/01/1751. Rolim de Moura vasculhou as áreas nas margens do Guaporé, com o intuito de definir o local mais adequado para a edificação da cidade: a capital da Província de MT. Percorre a região mineradora de Pouso Alegre e funda a Vila Bela da Santíssima Trindade em 19 de março de 1752. Seu propósito era, assim, o de:

[...] construir uma cidade que plantasse definitivamente as bases de domínio português sobre o novo território, articulasse o comércio entre a Metrópole e a nova área de produção aurífera, controlasse a hemorragia do contrabando de ouro das minas de Mato Grosso, assegurasse o controle da produção e a cobrança dos quintos (BANDEIRA, 1988, p. 83).

A construção dos edifícios foi demorada, interrompida diversas vezes e por diferentes motivos: a maior parte dos materiais, como a pedra canga, a cal, as telhas, entre outros produtos, era importada, vinha de fora da capitania. 0 transporte também era difícil e demorado. Havia 
constantes surtos de pestes e as doenças era rotina em função da região ser alagadiça, terras baixas, lençóis freáticos aflorentes; as inundações periódicas também impediam o andamento das obras. De fato, as inundações e as doenças são os temas mais comentados nas descrições de Vila Bela à época, como nos diários de Alexandre Rodrigues Ferreira e nos documentos de Francisco José de Lacerda e Almeida.

Grande parte da população, com exceção evidente dos escravizados, vinha sobretudo de São Paulo, atraída pelos incentivos públicos concedidos pela coroa lusitana. A obsessão de Portugal por ouro tornou a construção de Vila Bela assunto prioritário. Tomar posse desta parte da América interior era garantir para si os recursos minerais. Construir a cidade que assegurasse os interesses da coroa. Mas, para tanto, houve um abrandamento do ordenamento jurídico, das leis que regiam a colônia, com incentivos para a instalação de trabalhadores livres na região.

Sobre o perdão de dívidas vultuosas e crimes de toda ordem, aos que viessem para as minas de Mato Grosso e para Vila Bela, sobre o relaxamento dos controles fiscais e até concessão de dispensa de alguns impostos [...], a primeira capital da Província de Mato Grosso se construía ao arrepio das leis, numa excepcionalidade consentida para garantir a atualização do direito de posse da nova fronteira no interesse de Portugal (BANDEIRA, 1988, p. 88).

Desta forma, para se expandir e tomar posse deste território, Portugal descumpria suas próprias leis, bem como os Tratados firmados com a Espanha.

A cidade estava organizada economicamente ao redor da mineração, o que a tornava altamente instável. Quando a mineração dava sinais de esgotamento, toda a produção sentia seus reflexos negativos. E a cidade entra em decadência e crise. 0 abastecimento era igualmente irregular e difícil. Em função das constantes cheias e secas, a agricultura também era precária. Quando faltava sal, por exemplo, o abate do gado era interrompido, pois não havia como conservar a carne e, assim, a alimentação da população ficava precária. Mas quem mais sofria, de fato, eram os escravos, cuja base de alimentação era o peixe seco - e não a carne vermelha -.

Os quilombos da região apresentavam um contraste com a insalubridade e instabilidade da capital. Ao contrário dos espaços urbanos de Vila Bela, os quilombos eram ricos em mantimentos, com uma econômica solidária, e formada predominantemente por indígenas e, em menor quantidade, negros escravizados (BANDEIRA, 1988; MACHADO, 2006).

A transferência oficial e em definitivo da capital da província para Cuiabá se deu em 28 de agosto de 1835, durante o Período Regencial. Mas desde o final da década de 1790 houveram petições para a mudança da capital. A primeira tentativa de mudança foi feita em 1798, sugerindo como capital ou Cuiabá ou Vila Maria de Cáceres. A partir de 1800 Vila Bela vai gradativamente perdendo sua importância econômica, e os sucessivos governadores-generais passam mais tempo em Cuiabá. Em 1820, muitos órgãos públicos (como a fazenda e a justiça) são transferidos para Cuiabá. Assim, Vila Bela, mesmo que não oficialmente já deixava de ser a capital. Vila Bela protesta. Envia ofício à Lisboa e no processo da Independência, que ocupa todo o primeiro semestre de 1822, fica mais próxima de Portugal, contrária à independência. Durante o período Regencial, em 1831, tenta elevar-se à categoria de distrito, mas em 1835 e pela lei no 19 de 28/08, formaliza-se a transferência em definitivo.

Para a antropóloga, Maria de Lourdes Bandeira, autora de obra de referência sobre Vila Bela,

A fase de efervescência do ouro em Vila Bela não durou mais que três ou quatro décadas. A consciência de sua instabilidade e precariedade de sustentação preocupava e atropelava seu fundador. 0 medo de que seu sucessor viesse a mudar a capital de Vila Bela perseguia Rolim de Moura. Para torná-la mais estável e garantir-lhe certa margem de irreversibilidade, cuidou de instalar Ouvidoria, Intendências e Provedoria, Casas de Fundição (BANDEIRA, 1988, p. 111).

Como se vê, a mudança da capital foi um processo que durou décadas, com o esforço permanente e a tentativa contrária de diversas pessoas, apesar da influência de Antônio Rolim de Moura junto à corte portuguesa. Mas, uma vez definida a independência, não havia mais motivos nem forças para mantê-la como capital (p. 112). 
Outrossim, por conta do contexto histórico inferido anteriormente, Vila Bela da Santíssima Trindade abriga espaços dotados de edificações históricas que são importantes referências, como as "Ruínas da Igreja Matriz" e o "Palácio dos Capitães-Generais", o Museu Histórico e Arqueológico Joaquim Marcelo Profeta da Cruz e as representações culturais da cidade, sob as formas de expressões reproduzidas, como danças (Congo e Chorado), festanças religiosas (Festança de Vila Bela), que retratam a identidade étnica relacionada com aspectos sagrados e profano da população vilabelense.

\section{ATRATIVOS SOCIOESPACIAIS E GEO-AMBIENTAIS NO/DO MUNICÍPIO DE VILA BELA DA SANTÍSSIMA TRINDADE-MT: O PARQUE ESTADUAL SERRA RICARDO FRANCO}

As unidades de conservação de proteção integral, a exemplo do Parque Estadual Serra Ricardo Franco, têm como objetivo básico preservar a natureza, sendo admitido apenas o uso indireto dos seus recursos naturais incluindo pesquisas científicas, atividades de educação e interpretação ambiental, recreação e turismo ecológico, desenvolvidas de acordo com as normas estabelecidas no seu plano de manejo (BRASIL, 2000). É com base nas diversas permissões/possibilidades informadas que as atividades de visita técnica realizada no município de Vila Bela da Santíssima Trindade com os discentes do Curso Técnico em Controle Ambiental Integrado ao Ensino Médio perpassam pelo contato direto com a unidade de conservação (UC) citada anteriormente.

Ademais, atualmente constata-se que os atuais processos produtivos aliados ao crescimento populacional são incompatíveis com a capacidade de suporte dos ecossistemas terrestres. São vários os aspectos que compõe a "crise ambiental" instaurada em escala global, como a escassez de recursos naturais, poluição ambiental e problemas sociais, como miséria e desigualdade.

Mais que componentes estes problemas são interdependentes e derivam de um modelo de desenvolvimento arraigado por uma compreensão fragmentada e obsoleta da realidade, cuja transcendência necessariamente requer mudanças na percepção, no pensamento e nos valores da humanidade. Nesse contexto, a humanidade está sendo despertada para a verdade básica de que a natureza é finita e que o uso equivocado da biosfera ameaça, em última análise, a própria existência humana (McCORMICK, 1992).

0 estabelecimento de áreas naturais protegidas - um dos eixos de sustentação conservacionista vem sendo utilizado como ferramenta para salvaguardar o patrimônio natural desde 1872, com a criação do primeiro parque nacional, o "Yellowstone National Park" nos Estados Unidos, sendo posteriormente adotado por outros países (DIEGUES, 1998). Segundo este autor, no Brasil, a primeira iniciativa neste sentido ocorreu em 1937, com a criação do Parque Nacional do Itatiaia. Hoje, o sistema federal de unidades conservação abrange 6,3\% do território nacional, dos quais $44 \%$ estão protegidos integralmente e 56\% constituem unidades de conservação (UC) de uso sustentável.

O conceito e manejo destas áreas evoluíram consideravelmente, cujas finalidades perpassam pela preservação da diversidade biológica, sustentação dos processos ecológicos fundamentais aliados à pesquisa científica, à educação ambiental, à recreação em contato com a natureza, ao turismo ecológico e ao desenvolvimento regional/ambiental ordenado.

Segundo Quintão apud Diegues (op.cit.), o código florestal brasileiro de 1965 definiu como parques nacionais as áreas criadas com a finalidade de resguardar atributos excepcionais da natureza, conciliando a proteção integral da flora, da fauna e das belezas naturais com utilização para objetivos educacionais, recreativos e científicos. Nessa perspectiva, ele destaca que o objetivo geral das áreas protegidas é preservar espaços com atributos ecológicos importantes. Algumas delas, como parques, são estabelecidas para que sua riqueza natural e estética seja apreciada pelos visitantes, não se permitindo, ao mesmo tempo, a moradia de pessoas em seu interior.

O parque estadual Serra Ricardo Franco localiza-se no município de Vila Bela da Santíssima Trindade, na porção oeste do Estado de Mato Grosso, na microrregião Alto Guaporé (figura 01). Conforme Mato Grosso (1998) a Serra Ricardo Franco está compreendida entre os paralelos $14^{\circ}{ }^{\circ}$ e $15^{\circ}$ de latitude Sul e os meridianos 60 e 60 $30^{\prime}$ de longitude Oeste de Greenwich.

O parque estadual Serra de Ricardo Franco se enquadra dentro da característica de UC de Proteção Integral (PI) e sua guarda está a cargo da SEMA-MT. Foi criado em 04 de novembro de 1997 através do Decreto Lei número 1.796 e possui área de 158.620,85 ha (figura 01). Conforme Mato Grosso 
(1997, p. 2) "os Parques Estaduais (...) destinam-se à proteção integral de áreas naturais inalteradas ou pouco alteradas pela ação do homem, que oferecem relevante interesse do ponto de vista científico, cultural, cênico, educativo e recreativo".

Destaca-se que a informação veiculada no ano de 2016 pelo governo mato-grossense dando conta que a SEMA-MT lançaria edital para contratação de empresa para fazer o plano de manejo da unidade de conservação e a partir daí efetivar a proposta abri-la para uso público na área de ecoturismo não se concretizou. Conforme Mato Grosso (2016) na área ocupada pela UC podem ser relacionados inúmeros atrativos: cachoeiras, piscinas naturais, vales e vegetação que reúne floresta Amazônica, Cerrado e Pantanal, com espécies únicas de fauna e flora, algumas possivelmente desconhecidas da ciência. Também se localiza nela a cachoeira do Jatobá, considerada a maior do estado de Mato Grosso, com cerca de 250 metros de queda d'água.

Figura 01: Localização do parque estadual Serra Ricardo Franco.

Fonte: elaborado pelo autor com dados disponibilizados por IBGE e SEMA-MT

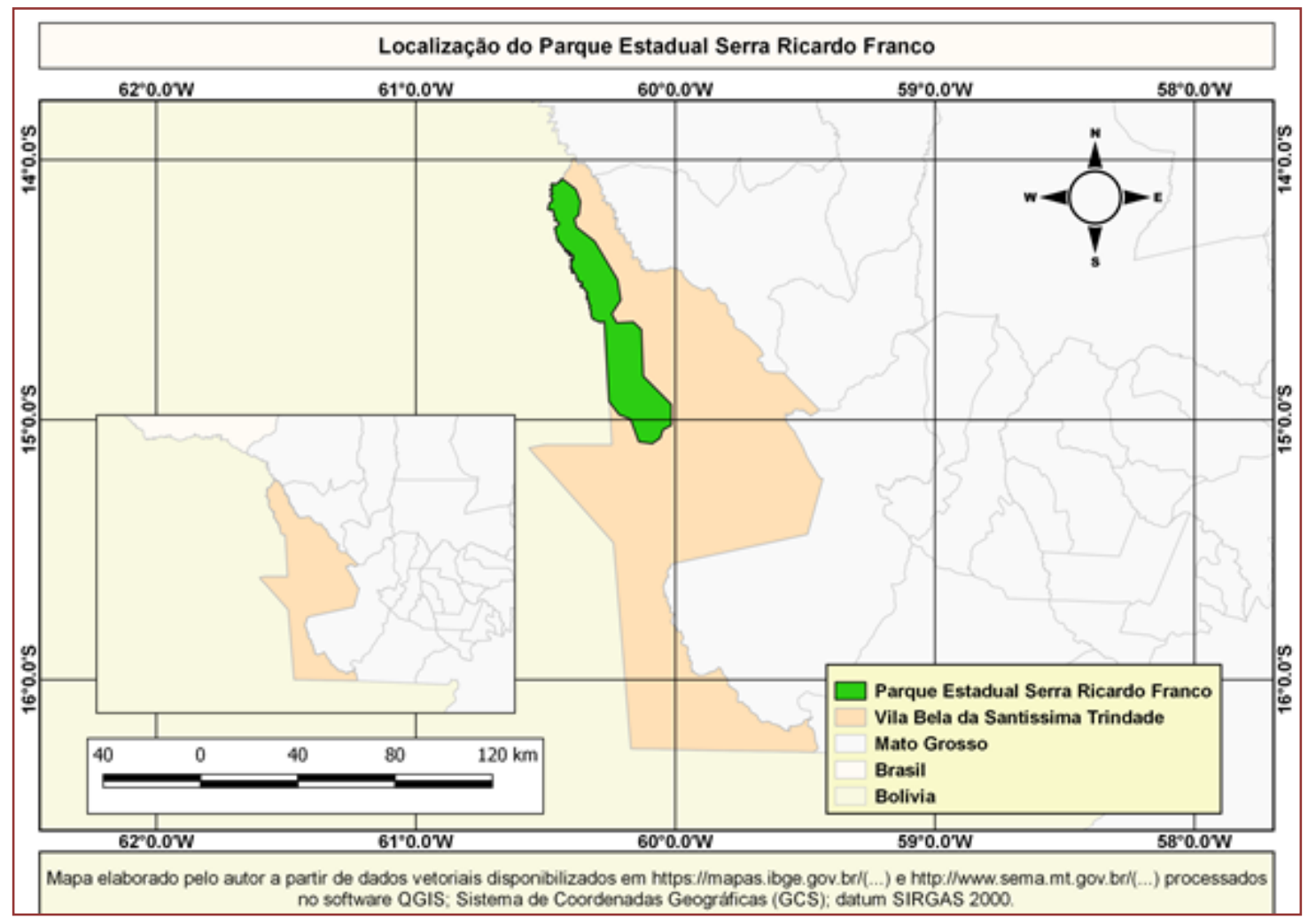

O parque estadual Serra de Ricardo Franco se enquadra dentro da característica de UC de Proteção Integral (PI) e sua guarda está a cargo da SEMA-MT. Foi criado em 04 de novembro de 1997 através do Decreto Lei número 1.796 e possui área de 158.620,85 ha (figura 01). Conforme Mato Grosso (1997, p. 2) "os Parques Estaduais (...) destinam-se à proteção integral de áreas naturais inalteradas ou pouco alteradas pela ação do homem, que oferecem relevante interesse do ponto de vista científico, cultural, cênico, educativo e recreativo".

Destaca-se que a informação veiculada no ano de 2016 pelo governo mato-grossense dando conta que a SEMA-MT lançaria edital para contratação de empresa para fazer o plano de manejo da unidade de conservação e a partir daí efetivar a proposta abri-la para uso público na área de ecoturismo não se concretizou. Conforme Mato Grosso (2016) na área ocupada pela UC podem ser relacionados inúmeros atrativos: cachoeiras, piscinas naturais, vales e vegetação que reúne floresta Amazônica, Cerrado e Pantanal, com espécies únicas de fauna e flora, algumas possivelmente desconhecidas da ciência. Também se localiza nela a cachoeira do Jatobá, considerada a maior do estado de Mato Grosso, com cerca de 250 metros de queda d'água.

Entretanto, existem algumas problemáticas inerentes ao uso racional da UC, principalmente àquelas relacionadas à regularização fundiária, pois na época de sua criação já haviam posseiros 
residindo o local e provavelmente ao longo de quase duas décadas diversas atores sociais promoveram "grilagem" de terras. Acrescenta-se também que as infraestruturas já instaladas dentro sua área vem sofrendo com a falta de manutenção e em grande parte não vem exercendo suas funções.

Com base na entrevista realizada com o gerente regional da UC, identificado como "L.M.", foi possível relacionar algumas problemáticas existentes e que tem impactado principalmente a gestão do parque. São eles: a atividade de garimpagem de ouro, o desmatamento, o pequeno número de servidores disponíveis para gerir a UC (apenas dois - gerente e assistente técnico), a baixa identificação da população local com a real função da UC, o uso incorreto nas atividades de lazer (ingresso de veículo, som alto, disposição de resíduos gerados etc.). Acrescentou-se também um certo "entrave" relacionado ao limite oeste da UC fazer fronteira com a Bolívia. Do lado boliviano existe o parque nacional denominado "Noel Kempff" e no período de estiagem a propagação de incêndio na região é constante e as ações insuficiente por parte dos responsáveis pelo parque boliviano coloca em risco o meio biótico do parque estadual Serra Ricardo Franco. Mas segundo o entrevistado o ponto mais preocupante é a questão fundiária da UC, visto que cerca de $80 \%$ de sua área é ocupada por propriedades privadas.

Para o gerente do parque, tal situação só deverá se amenizar com a criação do plano de manejo e adoção do mecanismo de compensação ambiental (os reais proprietários que estão na área receberão indenização em decorrência de atividades impactantes ao meio ambiente). Sendo assim, considera-se que a elaboração do plano de manejo da UC trará a sustentação legal para a mesma e ademais, mitigar e/ou excluir os conflitos existentes e vindouros, principalmente agrários e tornando assim reais e válidos os objetivos que se esperam para a UC.

Conforme apontamentos de Almeida (2016), as atividades de visitação praticadas em contato com atributos naturais e culturais de áreas protegidas buscam despertar o respeito e a importância destes recursos e o envolvimento da população humana com as UCs, mas que a falta de planejamento, normatização e fiscalização podem resultar em prejuízos tanto à experiência do visitante quanto à conservação da área.

\section{CONSIDERAÇÕES FINAIS}

A ciência geográfica tem como pressuposto principal observar a interação entre a sociedade e a natureza. A primeira como indutora de ações e intenções sobre a segunda, sendo esta o palco que enseja a nossa perpetuação como espécie. No município de Vila Bela da Santíssima Trindade, o Parque Estadual Serra Ricardo Franco serve como subsídio para análises da primeira natureza, visto que a Unidade de Conservação contempla um conjunto natural ímpar. Também em sua área de amortecimento vislumbra-se a produção de uma segunda natureza, visto que a antropização de tal área, através do cultivo de pastagens plantadas tende a produzir um quadro conflitante entre $o$ real objetivo da UC em destaque e o perfil econômico do município de Vila Bela da Santíssima Trindade, que assenta na pecuária bovina de corte sua principal característica econômica.

Ao apresentar um "toque" geográfico nesta temática, Serpa (2006) ressalta que o trabalho de campo é instrumento chave para a superação das ambiguidades da ciência geográfica, não priorizando nem a análise dos chamados fatores naturais nem dos fatores humanos. Ele deve se basear na totalidade do espaço, sem esquecer os arranjos específicos que tornam cada lugar, cidade, bairro ou região uma articulação particular de fatores físicos e humanos em um mundo fragmentado, porém (cada vez mais) articulado. Deste modo, e diante das informações apresentadas, julga-se a importância da visita técnica como forma de rever os conceitos teóricometodológicos e expressar o diálogo produzido em sala de aula, com a construção de conceitos a partir de observações feitas no desenvolvimento técnico-científico e reforçadas pelo método da visita técnica.

A visita técnica ou o trabalho de campo ou a aula de campo engloba uma única característica de atividade, que, definida de forma sucinta, terá a seguinte concepção: recurso didático usado para associar teoria e prática, ou seja, é uma atividade investigativa e exploratória que ocorre fora da sala de aula, visando a observação de determinados fenômenos nos locais onde eles ocorrem naturalmente. 


\section{REFERÊNCIAS}

[1] Almeida, Paulo Daniel Curti de. Uma nova direção para o "uso racional" do parque estadual Serra Ricardo Franco em Vila Bela da Santíssima Trindade-MT a partir da iminente criação do plano de manejo da unidade de conservação (UC). Anais Eletrônico do XVIII Encontro Nacional de Geógrafos. UFMA, São Luís/MA, 2016.

[2] Bandeira, Maria de Lourdes. Território negro em espaço branco. São Paulo: Brasiliense, 1988.

[3] Brasil. Lei Federal $\mathrm{N}^{\circ} 9.985$ de 18 de julho de 2000 (SNUC). Disponível em: <http://www.planalto.gov.br/ccivil_03/LEIS/L9985.htm>. Acesso em: 27. jun. 2016.

[4] Canavarros, Otávio. 0 poder metropolitano em Cuiabá (1727-1752). Cuiabá: Editora da UFMT/EdUFMT, 2004.

[5] Carbonell, Jaume. A aventura de inovar: a mudança na escola. Porto Alegre: Artmed, 2002 (Coleção Inovação Pedagógica).

[6] Diegues, Antônio Carlos Sant'ana. O mito da natureza intocada. 2. ed. São Paulo: Hucitec, 1998.

[7] Machado, Maria de Fátima Roberto. “Quilombos, Cabixis e Caburés: índios e negros em Mato Grosso no século XVIII”. Anais da 25ํㅜ Reunião Brasileira de Antropologia. Associação brasileira de Antropologia: Goiânia, 2006.

[8] Mato Grosso. Diário oficial do estado de Mato Grosso, de 04 de novembro de 1997. Disponível em: < https://www.iomat.mt.gov.br/>. Acesso em: 27. jun. 2016.

[9] Mato Grosso. Elaboração de estudo ecológico rápido para a criação e a implantação da unidade de conservação da Serra Ricardo Franco. Cuiabá: Fema/SPVS, 1998.

[10] Mato Grosso. Parque Serra de Ricardo Franco tem o maior potencial turístico do Estado. Disponível em:< http://www.mt.gov.br/-/3687737-parque-serra-de-ricardo-franco-tem-o-maior-potencial-turistico-doestado >. Acesso em: 27. jun. 2016.

[11] Mccormick, John. Rumo ao Paraíso: a história do movimento ambientalista. Rio de Janeiro: RelumeDumará, 1992.

[12] Peres, José Augusto de Souza. Visitas técnicas: o ensino fundamental, médio e superior. João Pessoa: Meta-EGM, 2005.

[13] Rodrigues, Antônio Brito; Otaviano, Cláudia Arcanjo. Guia metodológico de trabalho de campo em Geografia. Revista do Departamento de Geociências, Londrina, v. 10, n. 1, p. 35-43, jan./jun. 2001.

[14] Russel-Wood, John. Histórias do Atlântico Português. São Paulo: Editora Unesp, 2014.

[15] Serpa, Ângelo. O trabalho de campo em geografia: uma abordagem teórico-metodológica. Boletim Paulista de Geografia, São Paulo, v. 84, p. 7-24, 2006.

[16] Sousa, Cristiane Aureliane de. A aula de campo como elemento facilitador da aprendizagem nas aulas de Geografia no ensino fundamental. Monografia. Campina Grande: Universidade do Estado da Paraíba, 2014. 38. $\mathrm{p}$.

[17] Sousa, Cristiane Aureliane de et. al. A aula de campo como instrumento facilitador da aprendizagem em Geografia. Revista Educação Pública, Rio de Janeiro, v. 16, n. 22, p. 1-11, out., 2016. 


\section{Capítulo 3}

O brejo paraibano a partir de uma perspectiva de aula de campo interdisciplinar.

\section{Isadora Duarte da Silva}

Sibele Guilhermino Damázio

Resumo: Este trabalho é um produto de uma aula de campo interdisciplinar, com os componentes curriculares de Climatologia, Antropologia Cultural e Teoria e evolução do pensamento geográfico. Onde foram visitados alguns locais da Paraíba, no entanto, nesse capítulo serão apenas abordadas as particularidades da região do brejo, principalmente o clima, natureza e homem.

Palavras Chave: Brejo paraibano 


\section{INTRODUÇÃO.}

Para consecução dos objetivos, foram utilizados os seguintes procedimentos metodológicos: discursões e observações das paisagens se valendo do empirismo como um dos métodos da ciência geográfica. Foi utilizada a descrição da paisagem (vegetação, modos de vida das cidades, economia, cultura etc.), observações das paisagens e aplicação de matérias de climatologia como mapas, bússola, barômetro entre outros. Com o acompanhamento dos professores tivemos a apresentação de cada localidade, o percurso se deu de forma descritiva, analítica e empírica, onde os docentes descreviam com riqueza de detalhes os elementos da paisagem de cada localidade visitada.

0 processo inicial de ocupação do território do brejo paraibano ocorreu no século XVII, pelos colonizadores. A cana era produzida nas áreas serranas do brejo e processadas em engenhos rústicos. Desde sua introdução conviveu com a agricultura alimentar praticada pelos moradores e escravos. Posteriormente, com seguimento de culturas, principalmente a cana, deram origem ao que alguns historiadores designam de ciclo econômico do brejo. Essas culturas também foram responsáveis por modificar a paisagem da região de modo irreversível, que hoje se encontra apenas manchas da vegetação original.

As historias das cidades são de suma importância para compreender os vários acontecimentos da sociedade. É através dela que o homem conhece suas origens, além disso, ela pode se tornar algo que faça parte da vida e do cotidiano da sociedade, com esta pode ser organizados eventos que tragam cultura e valorização para a cidade, sem contar o retorno financeiro que a mesma traz como acontece na cidade de Alagoa Grande e Areia.

Figura 1: Cidades visitadas.

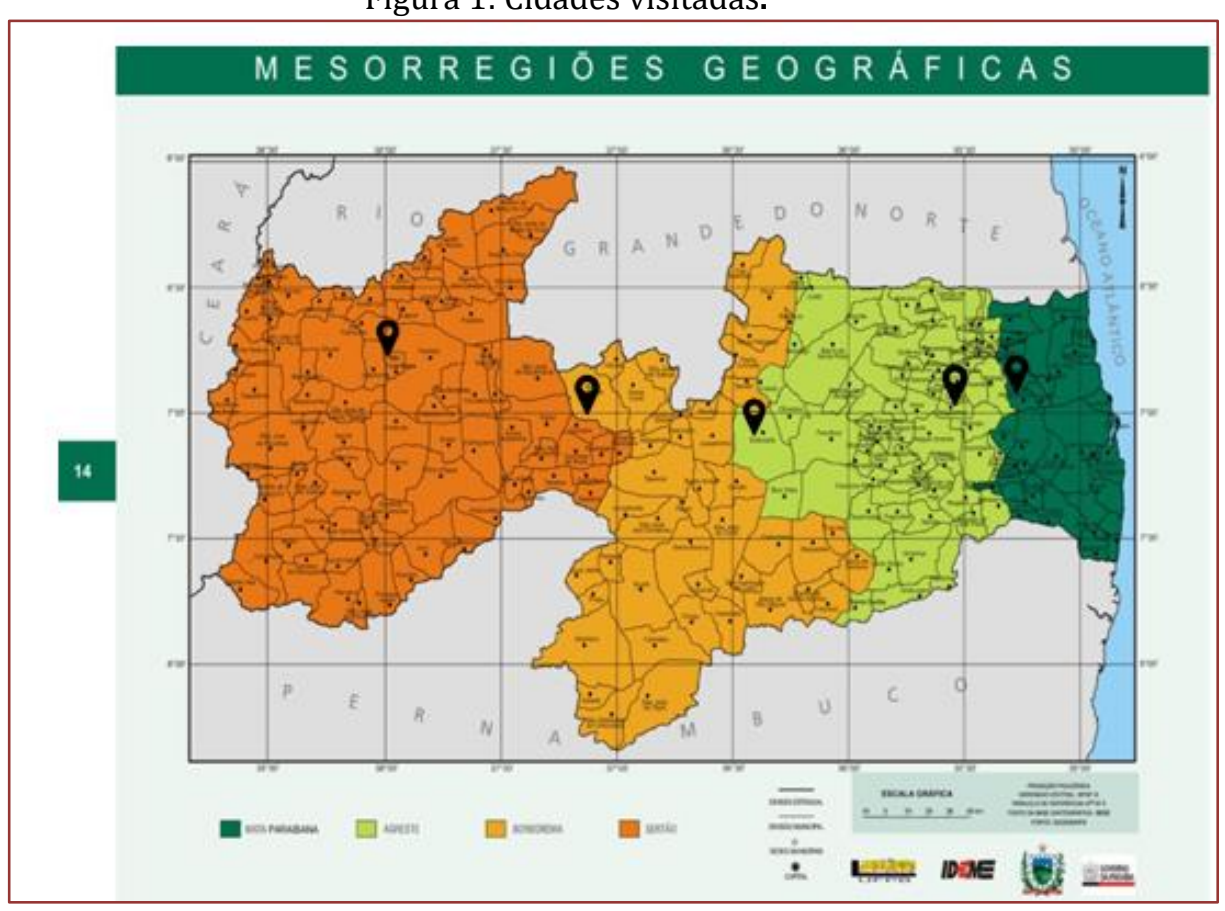

Fotografia: IBGE. 


\section{GUARABIRA (UEPB).}

Guarabira é a nona cidade mais populosa da PB, o município tem um comércio muito dinâmico, pois está localizado em uma região em que polariza mais de 30 cidades e todas tem grande vinculo com ela, assim sendo tendo uma grande participação na economia do estado.

A análise de Guarabira se deu mais nas questões naturais da cidade e os fatores para seu clima. 0 clima de um local se dá por alguns fatores, como o relevo, altitude, longitude, continentalidade, maritimidade, vegetação, massa de ar e outros. Com isso, foram feitas essas observações com a ajuda de ferramentas de climatologia (figura 2).

Assim, formasse o clima da cidade, que é o clima tropical úmido e quente. 0 relevo é um dos principais fatores para esse clima, em razão da cidade ser rodeada por montanhas e a cidade se encontrar em uma depressão, o vento tem dificuldade de passar. As chuvas dessa região são orográficas, ou seja, há uma precipitação quando uma massa de ar carregada de humidade sobe ao encontrar uma elevação do relevo que no caso é a Serra da Jurema, o verão é quente e seco e inverno úmido. A vegetação nessa área é um pouco seca e possui arvores arbustivas.

Tabela 1: Dados gerais de Guarabira

\begin{tabular}{|c|c|c|c|c|}
\hline Latitude & Longitude & Altitude & Pressão & Temperatura \\
\hline 6-52'03" Sul & 3529'59" Oeste & $136 \mathrm{~m}$ & 996 MBA & 290 \\
\hline Vento & Nuvens & Relevo & Solo & \\
\hline - & Extrato cumulus & - & Urbanizada & \\
\hline
\end{tabular}

Figura 2 - Matérias de climatologia

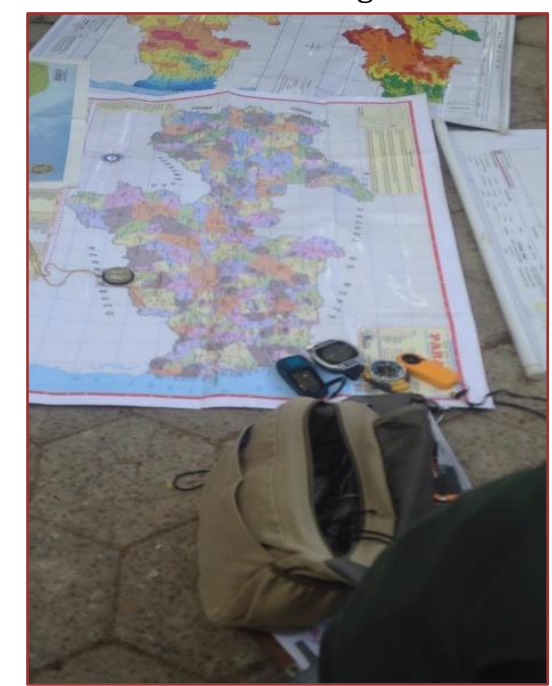

Fotografia: Sibele Guilhermino.

\section{ALAGOA GRANDE.}

Alagoa Grande também se localiza no brejo paraibano. Está situada na encosta da Serra da Borborema, tem clima tropical e uma cobertura vegetal de mata atlântica, no entanto, a cidade foi uma grande produtora de cana-de-açúcar e por isso, hoje existem apenas manchas da mata.

A cidade começou a se desenvolver através da agricultura baseada na cana-de-açúcar e se utilizava a mão de obra escrava, no centro da cidade tem essas marcas, como os casarões. A instalação da Usina Tanques também contribuiu na economia ao aumentar a produção dos derivados da cana de açúcar, como a cachaça. "Em 1928, com a instalação da primeira usina de açúcar no Brejo Paraibano, a Usina Tanques, no município de Alagoa Grande e dois anos depois com a fundação da segunda usina, a Santa Maria no município de Areia, teve lugar a retomada da atividade canavieira como mola mestra da economia agrícola regional." (PAIVA, p.46). 
Alagoa grande além de ter sido uma grande influenciadora na economia na Paraíba, tem uma cultura rica. Umas das influencias da historia da cidade é Jackson do Pandeiro, que foi cantor, instrumentista, compositor e um dos maiores intérpretes dos ritmos do nordeste como o samba e o forró brasileiro, diferente de alguns cantores da época, ele não cantava as mazelas do Nordeste e sim, a urbanização, cidades, amor etc. E nos movimentos sociais, se destaca a Margarida Maria Alves, foi uma sindicalista que correu atrás dos direitos das mulheres e homens negros, queria igualdade entre todos e direitos trabalhistas para os trabalhadores do campo. Nos dois casos tem memórias na cidade para visitas.

\section{AREIA.}

Antes de chegar à cidade de Areia, região do Brejo, foi observada uma elevação rápida da altitude, onde saímos de 136 e chegamos a mais de 600. Essa brusca mudança, diferencia a paisagem, com arvores arbóreas e mais verdes por causa da humidade relativa do ar. Às $10 \mathrm{~h}$ e $12 \mathrm{~min}$, a temperatura era de $30^{\circ}$, no entanto, a sensação térmica era em média $26^{\circ}$, por causa da altitude e umidade.

Areia se destaca mundialmente por sua pluralidade cultural. Na pintura se destacou Pedro Américo, além de pintor ele foi romancista, filosofo político, poeta, professor brasileiro etc. Os quadros mais famosos dele são: Independência ou Morte! também conhecido como 0 Grito do Ipiranga, A Batalha de Avaí (figura 3), entre outros. Na cidade, encontra-se a casa de Pedro Américo, com objetos e quadros contando sua história. 0 principal objetivo é preservar, tornar pública e enaltecer a vida pessoal e profissional do pintor. Também é visto arquiteturas barrocas, que fica evidente no teto da Igreja Matriz Nossa Senhora da Conceição, com a ilusão do movimento e jogos de claro-escuro (figura 4). 0 atual e o passado vivem em choque, isso mostra a cultura como era e é em dois períodos diferente, uma busca pela identidade.

Areia já foi uma grande produtora de café, a segunda região mais importante do Brasil na produção do café e antes, já se destacava com a lavoura de algodão. 0 solo fértil, parecido com o solo roxo, fez com que essa produção se desenvolvesse e se diferenciasse das outras.

O livro "Capítulos de Geografia Agrária da Paraíba”, explica como se deu esse processo da cana.

Embora cultivada desde o princípio do processo de ocupação, paralelamente as culturas alimentares, a cana-de-açúcar não foi dominante no sistema de uso de recursos regional em razão, seja em razão, seja da distância do algodão, a cana torna-se a cultura principal do Brejo. A sua expansão foi possível, não só graças as condições naturais próprias ao seu cultivo aí existente (clima quente e úmido e solos férteis), como também ao capital acumulado durante o ciclo algodoeiro e a estratégia adotada de produzir para o mercado interno. Ao substituir o algodão ela deu origem ao "ciclo da cana" no Brejo. (MOREIRA e TARGINO, 1997. p.87).

A cidade também tem o Parque Estadual Mata do Pau-Ferro (figura 5). Sua vegetação é a Mata atlântica ou floresta do Brejo de altitude. Um ponto bem interessante que deve ser frisado é que essa mata apresenta forte semelhança com a Mata Atlântica, por isso, alguns estudiosos consideram que ela corresponderia a uma disjunção da Mata Atlântica Costeira. "No que se referem à cobertura vegetal original do Brejo Paraibano, apenas duas áreas mais contínuas ainda são encontradas: a Reserva Ecológica Estadual da Mata do Pau-Ferro com área de 607 hectares, situada no município de Areia e a Área de Relevante Interesse Ecológico Mata de Goiamunduba com área de 67 hectares, localizada no município de Bananeiras. Estas áreas são testemunhos de que a formação serrana de mata atlântica era predominante em todo o brejo paraibano" (PAIVA, p.41). No entanto, 0 ambiente natural do Brejo sofreu importantes mudanças no decorrer do processo histórico de ocupação do espaço regional, a ambição e a necessidade do homem, causou a região grande pressão, desmatamento, para dá lugar as culturas agrícolas, principalmente para o cultivo da cana-deaçúcar. Deste modo a natureza é comandada pelas ações dos homens, a atividade social começa a ser uma interação entre o trabalho do homem e a natureza modifica por esse mesmo trabalho.

Hoje, ela é uma reserva ecológica e tem proteção do estado, pois a mata é de suma importância, por cobrir praticamente toda a área de captação da represa de vaca brava, reservatório que garante o abastecimento de água para vários municípios do Brejo Paraibano. Areia do ponto de vista dos 
recursos hídricos tem uma participação em dois rios de importância para a região, servindo como um divisor de águas comporta tributários para os rios Mamanguape e o Araçagi.

A mata tem grande importância na economia da cidade, proporciona o turismo e frutas para a população, que muitos utilizam para a produção de doces, o solo é rico por causa da decomposição das próprias arvores, misturados a terra. Isso ocasiona uma cultura diferenciada, onde os moradores se dedicam ao turismo, a culinária de acordo com os frutos da mata, assim cria hábitos diferentes para atender os visitantes.

Analisamos que na mata a temperatura é menor que na cidade, isso acontece por vários fatores, como o solo, que na cidade é urbanizado e consequentemente esquenta mais, estava com $30^{\circ}$, e na mata é solo serapilheira, não esquenta tão rápido e tem a interferência da mata fechada, a incidência do sol não chega diretamente no chão, estava com $25^{\circ}$. A altitude interfere na vegetação do local, há uma maior diversidade de arvores, dos arbustos às arbustivas. Observamos também, a latitude, longitude, relevo etc (tabela 2).

Figura 3 - A Batalha de Avaí

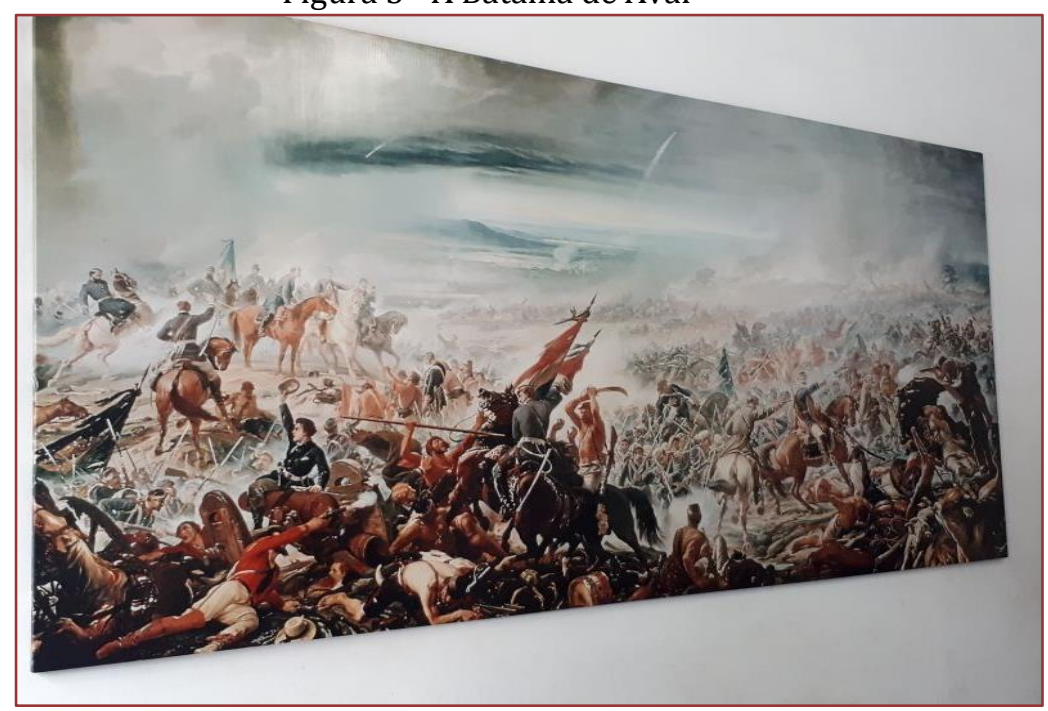

Fotografia: Isadora Duarte.

Figura 4 - Teto da igreja de Areia

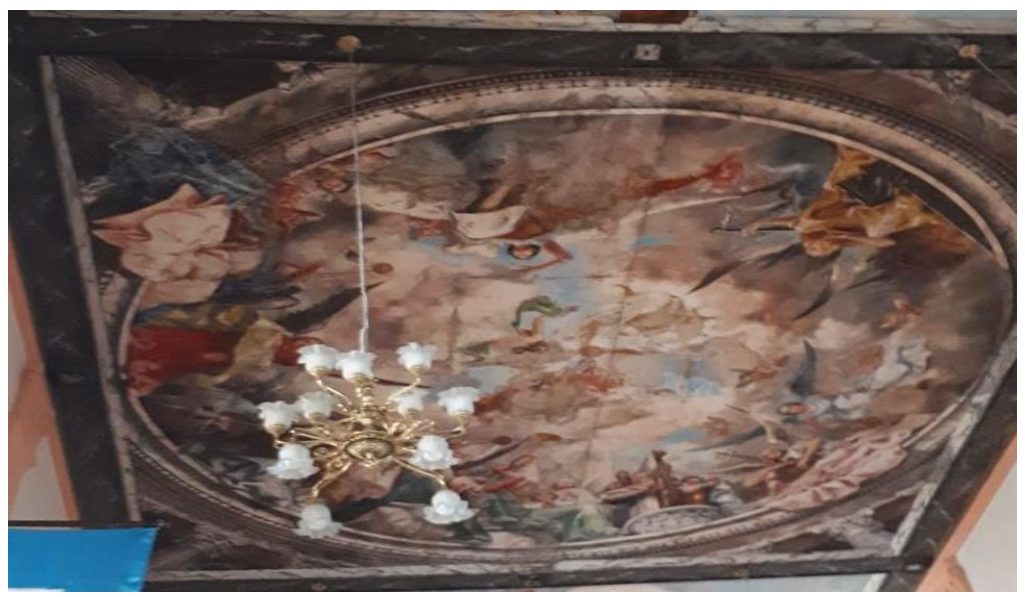

Fotografia: Isadora Duarte. 
Geografia no Século XXI- Volume 3

Tabela 2: Dados gerais da Mata do Pau Ferro

\begin{tabular}{|c|c|c|c|c|}
\hline Latitude & Longitude & Altitude & Pressão & Temperatura \\
\hline 6057'49" Sul & $35 \div 45^{\prime} 01^{\prime \prime}$ Oeste & $637 \mathrm{~m}$ & $940 \mathrm{MBA}$ & $25^{\circ}$ \\
\hline Vento & Nuvens & Relevo & Solo & \\
\hline Floresta fechada & Nimbus stratus & $\begin{array}{c}\text { Chã do planalto } \\
\text { da Borborema }\end{array}$ & Serapilheira & \\
\hline
\end{tabular}

Fonte: Aula de Campo.

Figura 5 - Mata do Pau Ferro

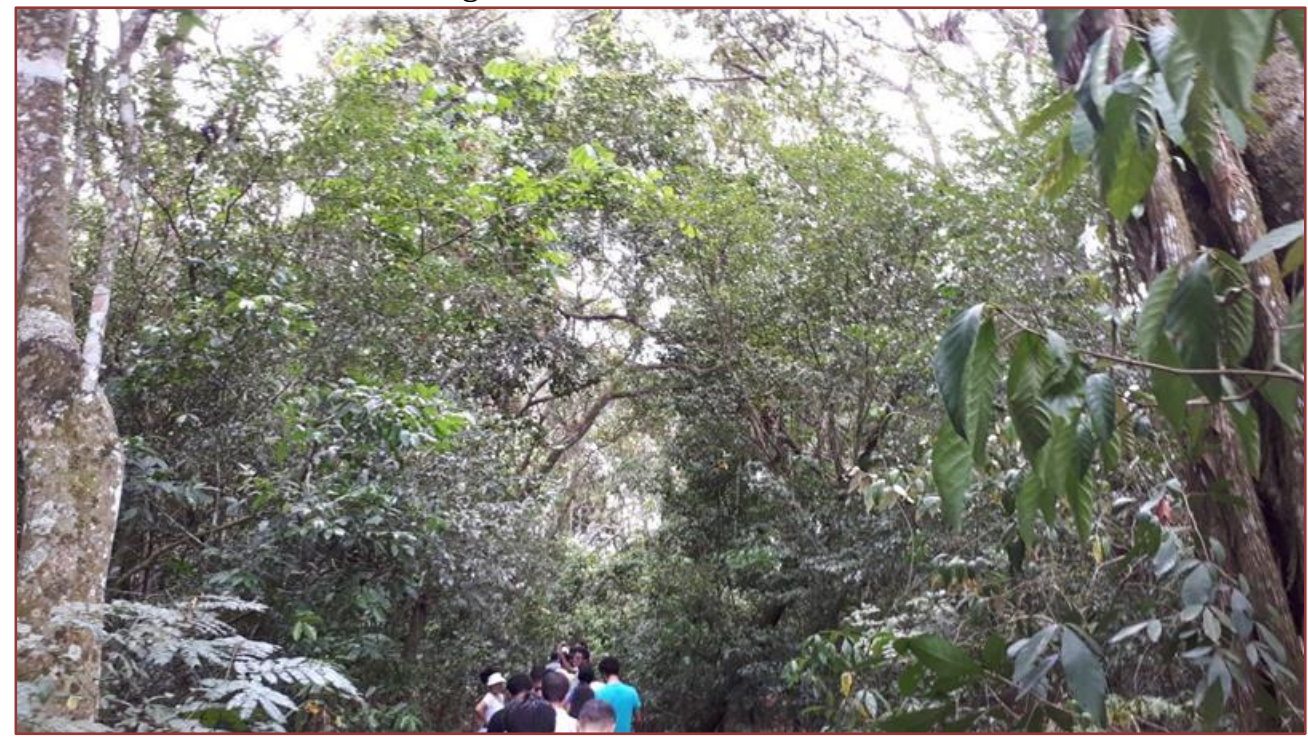

Fotografia: Isadora Duarte.

\section{FASE DE TRANSIÇÃO}

Remijo é a ultima cidade do brejo que conhecemos, o município está inserido na unidade geoambiental do Planalto da Borborema, e é cortada pela BR 104. Sua vegetação é florestas subcaducifólica e caducifólica, clima semiárido e hidrografia bacia hidrográfica do Rio Mamanguape.

Em seguida, passamos por Esperança, que se encontra no agreste. 0 município está incluído na área geográfica de abrangência do semiárido brasileiro, definida pelo Ministério da Integração Nacional em 2005. Esta delimitação tem como critérios o índice pluviométrico, o índice de aridez e o risco de seca.

Essa transição de regiões fica evidente na paisagem e na vegetação. Enquanto em Remijo a vegetação era arbustiva e verde, enquanto em Esperança a caatinga começa a aparecer, formada por arvores de pequeno porte. Surgi no senário também, a dificuldade dos paraibanos em busca por uma vida melhor e a falta de políticas públicas do uso da água, sendo que a maioria sobrevive por meio da agricultura e pecuária.

\section{CONSIDERAÇÕES FINAIS}

A atividade de campo realizada proporcionou uma melhor interação e entendimento das diferentes regiões que foram visitadas, observando de perto cada bioma, clima, cultura etc., principalmente da região do brejo, e a partir da aula foi mais fácil de entender as diferenças e particulares de cada uma.

Na cultura, podemos analisar as inter-relações entre o homem e o meio ambiente. A busca por uma vida melhor, mesmo com a seca que dificulta, sendo que a maioria sobrevive por meio da agricultura e pecuária na fase de transição. Um ponto proveitoso da aula de campo foi conhecer um pouco mais de perto a cultura paraibana, que não é vista e nem valorizada, inclusive pelos próprios 
paraibanos. Na Climatologia, foi mais fácil de entender os fatores responsáveis pelo clima, analisando e observando o que foi estudado em sala, compreender as diversas vegetações e biomas.

Além disso, fica evidente que no campo se aprende tanto como em sala de aula. Reconhecemos o trabalho de campo como importante ferramenta para a ciência geográfica, onde é ao mesmo tempo tanto uma metodologia de pesquisa, quanto um recurso para o ensino. 0 trabalho de campo proporciona uma melhor compreensão e articulação do aprendizado e isso é de suma importância para os futuros geógrafos.

\section{REFERENCIAS:}

[1] Albuquerque Junior, Durval Muniz de. Espaço da Saudade. In: A Invenção do Nordeste e Outras Artes. 5. ed. São Paulo. Cortes Editora, 2011.

[2] Mendonça, Francisco e Moresco, Inês. A interação dos elementos do clima com os fatores da atmosférica geográfica. In: Climatologia: noções básicas e climas do Brasil. São Paulo. Oficina de Textos, 2007.

[3] Moreira, Emília e Targino, Ivan. A cana-de-açúcar e sua importância na organização da produção e do trabalho do Brejo. In: Capitulo De Geografia Agrária Da Paraíba. João pessoa. Editora universitária UFPB, 1997.

[4] Rodriguez, Janete. Mapeamento Cultura - Paraíba. 2. ed. João Pessoa. Editora Grafset, 2000. 


\section{Capítulo 4}

As potencialidades da literatura como objeto de pesquisa para a geografia: Novos caminhos por vertentes ficcionais

Marcele Lima de Oliveira

Sharlene da Silva Bernardino

Maria Aletheia Stedile Belizário

Resumo: 0 presente trabalho objetiva-se a instigar possibilidades de diálogo e análise de leituras ficcionais pela Geografia, assim visando contribuir para possíveis novos estudos/usos relacionando a ciência e a arte, respeitando sua forma, pluralidade e semântica. Esta pesquisa foi construída em formato totalmente bibliográfico, com menção a autores que buscam o diálogo entre a Geografia e a Literatura. 


\section{INTRODUÇÃO}

A relação entre a ciência geográfica e os textos literários tem início formalmente no início do século XX pela escola francesa na área regional baseado em descrições realistas. Apenas na década de 1970, a literatura obteve algum destaque nas pesquisas da Geografia, em duas vertentes principais: uma pela escola cultural inglesa vinculada a corrente humanista, onde a relação entre autor e lugar era o foco da discussão; e outra pelos críticos basicamente selecionando textos de denúncia social (BROSSEAU, 2007a).

No Brasil, a literatura vem sendo debatida pela geografia cultural, também, desde a década de 1970, porém ainda a passos lentos. As pesquisas cresceram apenas quantitativamente, porém ainda com tendência a estudos sobre textos onde o real é primorosamente descrito ou sobre o uso de alguns textos literários em sala de aula (CORRÊA, 1998).

Geralmente sendo baseados em descrições, diários de viagens ou romances de tempos passados, como por exemplo, 0 cortiço, de Aluísio Azevedo, Homens e Caranguejos, de Josué de Castro e Vidas Secas, de Graciliano Ramos ${ }^{1}$. Estes textos são de grande importância para a construção do imaginário nacional, exemplos da forma brasileira de escrever e utilizados até hoje como subsidio para literatura na escola.

Apesar dessas publicações, a ficção, suas ramificações e outros gêneros mais livres e distantes do real ainda não contam com um número expressivo de pesquisas. A literatura ficcional, mesmo tratando-se de uma expressão artística livre por essência, ainda tem raízes fincadas no real, podendo trazer novos olhares sobre o passado, presente ou futuro, pois também carrega elementos histórico-geográficos. Alguns textos ficcionais que já foram analisados em trabalhos geográficos foram: Nós, de Zamyatin, 1984, de George Orwell e Admirável Mundo Novo, de Aldous Huxley².

Este artigo foi produzido a partir de indagações e justificativas que a autora teve que se deparou durante a escrita do trabalho de conclusão de curso, que atualmente já foi aprovado. Posicionamentos contrários e/ou duvidosos instigaram a procura por maior base, defesa e, ao mesmo tempo, novas perguntas sobre esta temática e, então, culminou neste texto que não ousa afirmar que está completo.

Portanto, o presente trabalho objetiva-se a instigar possibilidades de diálogo e análise de leituras ficcionais pela Geografia, assim visando contribuir para possíveis novos estudos/usos relacionando a ciência e a arte, respeitando sua forma, pluralidade e semântica. Esta pesquisa foi construída em formato totalmente bibliográfico, com menção a autores que buscam o diálogo entre a Geografia e a Literatura. Vale mencionar a contribuição dos colegas no EDP do evento para a construção do texto final.

\section{GEOGRAFIA E LITERATURA FICCIONAL}

A literatura consegue ser um grande instrumento de apoio no ensino de geografia, por meio da prática interdisciplinar, e a maioria dos trabalhos publicados nos últimos anos que abarcam a literatura utilizam desta relação com o ensino. A sua facilidade de comunicação com os jovens e seu grande público atual avigoram a necessidade do olhar geográfico sobre ela.

Todo texto literário é uma ficção, pois este é um discurso conotado (VILANOVA NETA, 2005). Esta afirmação, por si só, já cunha como justificativa que a ciência geográfica dialogue e se debruce também sobre as ficções, principalmente sobre as escritas nos últimos anos. Ora, se um romance datado de séculos atrás falando sobre o imaginário local, símbolos e etc. tem sua utilidade para a ciência geográfica enquanto documento, levando em conta que a tal paisagem não mais existe, por que ignorar a enorme produção de textos literários de ficção publicados nos últimos anos? Estes também expressam o imaginário deste tempo, o contemporâneo e sua leitura específica de mundo.

"O texto literário não pode ser considerado ultrapassado, isto é, como algo que não merece consideração e que não se insere nas tecnologias do momento, pois ele nunca perderá sua importância e sempre provocará sensações no leitor. Além do prazer estético, ele permite sentidos

\footnotetext{
${ }^{1}$ Estes livros já foram utilizados em trabalhos de autores da ciência geográfica.

2 Todos os livros citados são considerados distopias, definidos como textos ficcionais abordando um futuro pessimista a partir de características pejorativas existentes no presente (da escrita).
} 
múltiplos em diferentes espaços e tempos. É por isso que as obras literárias resistem ao tempo e as mudanças" (MORAES, 2012, p. 28).

Este pensamento é pertinente já que "o romance se constitui como um espaço privilegiado de expressão dos conflitos sociais e ideológicos, composto de contradições elaboradas pelo autor a partir de dadas situações existentes em seu horizonte de vivências" (CARVALHO, 2014, p. 87). Ele não tem limitações que certos tipos de texto teriam para retratar sobre assuntos considerados como tabu, por exemplo.

Enquanto textos que abordam lugares reais, consideramos que a ciência geográfica também ganha em aspectos de análise especial destas localidades, "se recorrer ao texto literário respeitando sua natureza polissêmica, buscando entender de que maneira o espaço está representado na trama, e que elementos presentes nessa representação podem acrescentar ao próprio olhar geográfico" (VILANOVA NETA, 2009, p. 91).

A ficção literária é capaz de instigar o leitor a solidificar um espaço imaginário construído pela leitura numa paisagem em nível abstrato, como uma imagem espacial. Mesmo se tratando de algo não tangível, o leitor tem a capacidade de visualização a partir do que lê. Cada livro tem inúmeras possibilidades de leitura a partir de variáveis comuns, desde o momento histórico e local onde foi escrito até por quem pode ser lido, nas palavras de Gabriela Rodriguez Fernandez:

"Escritor e leitor são pares inseparáveis de uma relação em espiral pela qual todo escritor é, por sua vez, um leitor de outros, e cada leitor reescreve mentalmente aquilo que lê, selecionando do texto as partes que, de acordo com seus interesses e necessidades, parecem-lhe mais relevantes. 0 mesmo livro, lido por leitores de época e espaços físicos distintos, é um produto literário diferente" (FERNANDEZ, 2013, p. 36).

A percepção do mundo de cada pessoa em si é diversa, até mesmo durante diferentes estágios de sua vida. 0 passado desta quando contado também pode ser considerado ficção por aqueles que não passaram por devida experiência, por exemplo, mesmo sendo um documento oral. Insistimos muito no que é (ou não) ficção para que possamos desvincular a ideia de que um universo literário possa ser diferente ao ponto de ser desmerecido.

A ciência geográfica tem conceitos e abordagens específicos enquanto ciência e estes podem ser incorporados na leitura do mundo literário. Maiormente, em momentos onde a Geografia utiliza dos textos literários são de forma instrumental, isto é, trazendo afirmações para os livros que teriam apenas a função de corroborar os pensamentos do pesquisador. O ponto em que nos questionamos criou uma suposição e esta é arriscada, deixamos aqui para ser possivelmente respondida futuramente: E quanto ao que os autores escrevem sobre o que não existe, mas é baseado/inspirado em algo existente? Como ler e incorporar estes textos a Geografia?

Elementos geográficos são presentes na grande maioria dos textos literários fictícios, seja em forma descritiva de paisagens com elementos naturais, urbano-rurais, econômicos, culturais e etc. E estas conjunturas podem ser relacionadas a conceitos e temas básicos à ciência geográfica, com certa facilidade.

Propomos e introduzimos esta discussão para que mais pesquisas e diálogos sobre este assunto passem a ser fomentados, pois a literatura tem sido um assunto entre jovens, advindo de fora da escola, pela internet ou grupos de amigos com interesses em comum. Ao conhecer estes movimentos, nós, pesquisadores e enquanto professores, abrimos mais um canal de comunicação e até identificação entre os alunos.

Pois, "a Literatura, mais do que os levantamentos das ciências sociais, nos fornecem informação detalhada e minuciosa de como os seres humanos percebem seus mundos" (TUAN, 2012, p. 78). Como os atuais jovens enxergam este e outros mundos? Será que os livros ajudam que eles encontrem elementos destoantes que são desejados nestes e não existentes na realidade? Qual são as Geografias da ficção contemporânea?

Estas indagações são as mais importantes, as basilares do que propomos neste pequeno artigo. Aqui registramos e compartilhamos as primeiras perguntas que nos desafiamos a responder no futuro, através da continuação desta pesquisa e da constante indagação que é inerente ao pensamento científico. 


\section{CONSIDERAÇÕES FINAIS}

Como repetimos de forma exaustiva, este texto se propõe a abrir questões, instigar respostas e pesquisas sobre a literatura fictícia e sua fala em um diálogo construído com a ciência geográfica, com a difícil missão de não restringi-la a posição de instrumento. Mesmo que este trabalho tenha deixado propositalmente perguntas abertas, sem respostas, esta era a finalidade enquanto um texto publicado em um evento que se propõe a troca de ideias e atualizações do ambiente acadêmico.

Já existem artigos e até trabalhos de conclusão onde a pesquisadores da Geografia estabelecem um diálogo com a Literatura de uma forma mais respeitosa enquanto entendedor que a Literatura não é um texto científico e, sim, cheio de nuances. As vertentes ficcionais aos pouco tem tido espaço nestas pesquisas, como a poesia e o romance, e tendencial a continuar crescendo. Reforçamos a necessidade da revisão de textos mais atuais, gêneros mais difundidos como as histórias em quadrinhos (HQs) e a literatura fantástica, movimentos em que tem fortalecido a formação da identidade das novas gerações para assim aguçarmos o nosso olhar geográfico.

\section{BIBLIOGRAFIA}

[1] Carvalho, R. J. Reflexões sobre Geografia e Literatura. Ágora Revista Eletrônica. [s. v.], ano X, no 19, dez. 2014. P. 80-89. ISSN 18094589.

[2] Côrrea, R. L. Geografia, Literatura e Música Popular: Uma bibliografia. Espaço e Cultura, UERJ, Rio de Janeiro, [s. v.], n. 6, p. 59-65, jul./dez. 1998. ISSN 1413-3342. Disponível em <http://www.epublicacoes.uerj.br/index.php/espacoecultura/article/view/3583>. Acesso em 03 mai. 2018.

[3] Brosseau, M. Geografia e Literatura. In: Côrrea, Roberto Lobato; Rosendahl, Zeny (orgs.). Literatura, música e espaço. 1 ed. Rio de Janeiro: EdUERJ, 2007. P. 17-78. Coleção Geografia Cultural; 14.

[4] Fernandez, Gabriela Rodriguez. A cidade como foco da imaginação distópica: literatura, espaço e controle. In: CÔRREA, Roberto Lobato; ROSENDAHL, Zeny (orgs.). Geografia cultural: uma antologia. Volume II. Rio de Janeiro: EdUERJ, 2013. P. 35-56.

[5] Moraes, M. M. Geografía e Literatura. Espacios, Santiago, Chile, v. 2, n. 3, p. 23-40, jul. 2012. ISSN 0719-7209 (Versão eletrônica). Disponível em: <http://www.revistaespacios.cl/?p=3748>. Acesso em: 01 abr. 2018.

[6] Tuan, Y. Topofilia: um estudo da percepção, atitudes e valores do meio ambiente. Londrina: Eduel, 2012. 342 p.

[7] Vilanova Neta, M. A. Geografia e Literatura: Decifrando as Paisagens dos Mocambos do Recife. Dissertação (Mestrado em Geografia). UFRJ/PPGG, Rio de Janeiro, 2005. 1 vol., il. 116 f. Cap. II.

[8] Vilanova Neta, Maria Amélia. Representações literárias da metrópole: Uma contribuição ao estudo do urbano em geografia cultural. Revista Espaço e Cultura, UERJ, Rio de Janeiro, [s. v.], n. 25, p. 85-96, jan./jun.
2009.
ISSN
1413-3342.
Disponível
em $<$
http://www.e-

publicacoes.uerj.br/index.php/espacoecultura/article/view/3565/2485>. Acesso em 01 abr. 2018. 


\section{Capítulo 5}

\section{Localización y especialización productiva: el caso de la región amazorinoquia de Colombia}

\section{Cristian Orlando Avila Quiñones}

Wainesten Camargo

Nilton Marques de Oliveira

Resumen: Esta investigación analiza la dinámica regional de las actividades productivas en la región Amazorinoquia de Colombia, usando medidas de localización para los años 2012 y 2017. Para ello, se utilizaron una serie de indicadores como el Cociente de Localización, el Coeficiente de Asociación Geográfica y el Multiplicador del Empleo. El objetivo de este trabajo consiste en verificar por primera vez la diversificación productiva en la región Amazorinoquia y la capacidad de generar empleo en cada sector de la economía. Los datos utilizados fueron extraídos del DANE según la rama de actividad económica, año 2018. Los resultados apuntan que la Economía regional posee un grupo de departamentos con sectores fuertemente asociados (complementarios) en su proceso productivo, en el que la minería es fundamental para jalonar al departamento líder (Casanare). Aunado a que, ningún departamento genera más del 15\% de empleo básico, mientras el empleo no básico si supera el $85 \%$ en la región.

Palabras Clave: Cociente de Localización, Especialización productiva, Región Amazorinoquia. 


\section{INTRODUCCIÓN}

Este trabajo tiene como objetivo principal estimar y analizar los indicadores de análisis regional por rama de actividad productiva en la geoeconómia colombiana tomando como referencia informaciones de las 8 capitales de los departamentos que conforman la región Amazorinoquia entre los años 2012 y 20173. El análisis estará direccionado para aquellos sectores con mayor capacidad de generación de empleo, utilizando como fuente de datos la Gran Encuesta Integrada de Hogares (GEIH) actualizada al año 2018, la cual tiene como objetivo principal brindar información sobre empleo, desempleo e inactividad de la población colombiana. En el año 2017 el Departamento Nacional de estadísticas (DANE) informó que Casanare siendo un nuevo departamento tiene el mayor PIB per cápita de Colombia con 11.328 USD vs la media nacional de $\$ 6.276^{4}$, pero el desempleo es de 10,4 vs la media nacional de 9,4.

En 2001 la Comisión Económica para América Latina y el Caribe (CEPAL) hizo pública una compilación de artículos titulada Desarrollo Económico Local y Descentralización. En este trabajo fue definido el concepto de desarrollo económico local como un proceso de crecimiento y de cambio estructural que visa aumentar el bien estar de una región. para alcanzar este tipo de desarrollo, también conocido como endógeno, es necesario que la localidad utilice de forma eficiente sus propios recursos económicos, humanos, institucionales y culturales. Del mismo modo, el documento anteriormente supracitado, afirma que el modelo de desarrollo local a diferencia del paradigma de los años cincuenta y sesenta, puede ser difuso y no concentrado en las grandes ciudades, sin embargo, el nuevo modelo endógeno comparte algunas ideas con el modelo anterior, como por ejemplo el hecho de que un aumento de la productividad y por ende del crecimiento económico, son consecuencia de factores externos como la innovación de empresas, producción en escala y la generación de mano de obra. BARQUEIRO (2000).

Galvis (2014) afirma que en Colombia tres cuartas partes de la población vive en los centros urbanos, debido a mayor calidad de vida, diversidad de bienes y servicios y mejores posibilidades de crecimiento económico. Por otro lado, el autor destaca que, si el Producto Interno bruto del país estuviera definido por la producción de tres sectores siendo estos industria, servicios y financiero, es muy probable que el $80 \%$ de la producción estaría concentrado en 6 departamentos: Cundinamarca, Antioquia, Valle del cauca, Santander, Atlántico y Bolívar. Vale la pena esclarecer que ninguno de los departamentos antes mencionados es nuevo. Sin embargo, los departamentos de Casanare y Arauca si hacen parte de este estudio, los cuales concentran la mayor parte del capital minero energético nacional. Aun cuando todo el panorama anteriormente descrito demuestre una concentración de la actividad económica. Maldonado (2000) afirma que en Colombia no existe el predominio de un solo centro urbano como ocurre en la mayoría de los países suramericanos y por el contrario existe una propensión a desconcentrar la actividad económica, relacionada al surgimiento de polos industriales en varios departamentos del país.

Además de esta introducción, este articulo incluye un análisis sobre algunas teorías de economía regional, seguida de una descripción sobre la posición geográfica de los departamentos que conforman las regiones de Orinoquia y Amazonia (las cuales en conjunto son conocidas como Amazorinoquia), continuando con una caracterización de los respectivos sectores económicos y se finaliza con las consideraciones finales.

\section{TEORIAS DE LA ECONOMIA REGIONAL}

La producción teórica en economía regional ha sido fundamental para el análisis de las economías locales a nivel mundial. Los significativos aportes realizados por Von Thunen (1966), Launhardt (1882), Alfred Weber (1969) e Walter Christaller (1966), sobre teorías de localización permitieron vislumbrar la importancia de algunos factores como los costos de transporte, mano de obra, distancia entre el mercado, recursos naturales y las ciudades dentro de la geografía económica, utilizando como base de estudio la actividad agrícola e industrial de la época.

\footnotetext{
${ }^{3}$ El país de Colombia se divide administrativa y políticamente en 32 departamentos, los cuales son gobernados desde sus respectivas ciudades capitales. Los departamentos forman regiones geográficas, culturales y económicas.

${ }^{4}$ Con base $2017, \$ 1$ dólar (USD) $=\$ 3.000$ pesos colombianos .
} 
A partir de los años cincuenta surgieron nuevos estudios sobre desarrollo regional basados en factores de aglomeración. Estos tuvieron como fuente de inspiración las ideas de Alfred Marshall (1890) quien argumentó en su libro principios de Economía sobre las ventajas que proporciona el intercambio de informaciones, y la abundante oferta de mano de obra, en mercados donde empresas del mismo sector tiende a aglomerarse. Posteriormente, autores como Perroux (1955) y Myrdal (1957) intentaron comprender los conceptos relacionados a la aglomeración inicialmente analizados por Marshall, todavía con la influencia de las ideas Keyneesianas y Schumpeterianas. MATOS (2007)

Perroux (1955) en su teoría de los polos de crecimiento presentó como idea central el impacto que puede ocasionar la existencia de un polo industrial complejo en la estructura económica de un determinado lugar, una vez que este estimula diversas actividades económicas en cadena. Una de las características del crecimiento analizado por Perroux es que este, no es simultaneo y la intensidad con que aparece es variable, propagándose en diferentes puntos de la economía. Por su parte Myrdal (1957) argumenta que las fuerzas del mercado tienden a aumentar la desigualdad dentro de una región o país, por lo que propone la intervención estatal para minimizar los efectos del mercado. Según Myrdal el proceso de causación circular y acumulativa de los países menos desarrollados es válido dentro del campo de las relaciones sociales, en donde un factor negativo causa otros factores negativos. Esta ha sido una de las contribuciones más relevantes de Myrdal, cuya base explicativa se encuentra en la Biblia. TOLEDO (1999).

Por otro lado, North (1955) realizó un trabajo de observación en diferentes regiones americanas y canadienses para verificar el proceso de desarrollo económico. El autor constato que muchas regiones evolucionaron sin necesidad de pasar por procesos evolutivos que implicaran sistemas agrícolas, economías de subsistencia, economías de servicios y una fase de sustitución de importaciones como otros economistas afirman. Como resultado de este trabajo surgió su artículo "Teoría de la localización y crecimiento Económico Regional" en el cual North argumenta que el crecimiento de una región está fuertemente vinculado al suceso de sus exportaciones básicas, mientras que los otros productos eran destinados a suplir el consumo local. Además, el autor afirma que la renta per capital y absoluta de una región también están relacionadas a las exportaciones, debido al efecto directo existente entre el empleo de la industria de exportación y el empleo de la industria local (NORTH, 1955).

Considerando las diferentes teorías existentes sobre análisis regional, es conveniente mencionar una compilación de estudios publicados por el Banco de la República de Colombia donde se da a conocer algunos de los factores que han determinado el desarrollo de las principales ciudades colombianas. Estos estudios afirman que las ciudades colombianas son un claro ejemplo de aglomeración de centros urbanos industriales. Sin embargo, esclarece que cuando se realiza el análisis en términos locales, es decir, cuando se compara la actividad industrial de una ciudad principal con respecto a su departamento la participación industrial es altamente significativa, no ocurriendo lo mismo cuando se compara con relación al ámbito nacional. Acosta (2014) afirma que en Colombia existen ciudades capitales como la ciudad de Cartagena que para los años de 1997 a 2004 representando casi el $100 \%$ |de su producción industrial con relación a su departamento (Bolívar), al ser comparada con la producción nacional el Departamento de Bolívar solo aportó el $6 \%$ del total nacional.

Para el caso específico de grandes ciudades colombianas como Bucaramanga (departamento de Santander) y Medellín (Antioquia), diversos autores apuntan que el crecimiento económico de esta región está explicado por el desarrollo de sus instituciones y su vínculo con el capital humano, entre otros aspectos geográficos. Al respecto, Aguilera (2003) afirma que Bucaramanga se distingue por tener un capital humano altamente capacitado y provisto de excelentes instituciones educativas, centros de investigación y desarrollo tecnológico. En este orden de ideas, es posible afirmar que Colombia cuenta con diversos factores que explican el desarrollo económico de sus regiones.

\section{METODOLOGIA}

El objetivo de esta sección es describir la metodología de los indicadores de análisis regional para las 8 ciudades capitales que representan la región de la amazorinoquia de Colombia entre los años 2012 e 2017 (se excluyen los departamentos del Meta y Caquetá, debido a su edad, económicamente no es adecuado comparar estos departamentos antiguos con los 8 departamentos restantes, dado que estos últimos, fueron creados tras la Constitución Política de Colombia en 1991. 
A partir de las medidas de localización fueron explorados tres indicadores: El cociente de localización (CL), el Coeficiente de Asociación Geográfica (CAG) y el multiplicador del empleo.

La variable utilizada en el análisis será el número de empleos formales distribuidos por sector económico, bajo el supuesto de que los sectores más dinámicos emplean más mano de obra a través del tiempo. Lo que termina estimulando el consumo y la distribución de la renta local y regional.

Los datos del empleo formal fueron extraídos de la Gran Encuesta de Hogares según rama de actividad con datos actualizados al año 2018. El periodo de análisis fueron los años 2012 e 2017 considerando los 10 sectores de la economía según rama actividad económica, implementado por el Departamento Administrativo Nacional de Estadística DANE, es decir: Agricultura, ganadería, caza, silvicultura y pesca; Explotación de Minas y Canteras; Industria manufacturera; Suministro de Electricidad Gas y Agua; Construcción; Comercio, hoteles y restaurantes; Transporte, almacenamiento y comunicaciones; Intermediación financiera; Actividades inmobiliarias, empresariales y de alquiler; Servicios comunales, sociales y personales.

Para estimar las medidas de localización las informaciones serán organizadas en una matriz que relaciona la distribución sectorial-espacial de la variable base que es el empleo formal. Las columnas muestran la distribución del empleo entre los departamentos y las líneas muestra la distribución de la mano de obra por sector de todos los departamentos analizados.

Considerando esa distribución se tienen las siguientes ecuaciones:

$$
\begin{aligned}
& E_{i j}=\text { Mano de obra en la rama productiva } i \text { del departamento } j \\
& \sum_{j} \text { Eij }=\text { mano de obra en la rama productiva } i \text { del departamento } j \\
& \sum_{i} \text { Eij }=\text { mano de obra en todas las ramas productivas del departamento } j \\
& \sum_{i} \sum_{j} E i j=\text { mano de obra en todas las ramas productivos y departamentos }
\end{aligned}
$$

A partir de las cuatro ecuaciones anteriores, se organizó el cuadro 1 que muestra las medidas de localización y el multiplicador de empleo. Las medidas del cociente de localización y coeficiente de asociación geográfica son de naturaleza sectorial representando la localización de las actividades productivas entre los departamentos, es decir, buscan identificar patrones de concentración o dispersión de la mano de obra por rama de actividad en un determinado periodo.

La ecuación del cociente de localización CL presentado en el cuadro 1 es utilizada para comparar la participación porcentual de la mano de obra del departamento con relación a la participación porcentual del total nacional. La importancia del departamento en el contexto nacional, en relación con el sector analizado, es demostrada cuando CL adquiere valores $\geq 1$, representando las actividades básicas. Los sectores con valores $<1$ serían los no básicos, lo que significa que la

\begin{tabular}{|c|c|c|}
\hline Indicador & Ecuación & Interpretación de resultados \\
\hline $\begin{array}{c}\text { Cociente de } \\
\text { Localización (CL) }\end{array}$ & $\mathrm{CL}=\frac{E_{i j} / \sum_{j} E_{i j}}{\sum_{i} E_{i j} / \sum_{i} \sum_{j} E i j}$ & $\begin{array}{l}C L \geq 1 \text { Localización significativa } 0,50 \leq C L \leq 0,99 \\
\text { localización media } C L \leq 0,49 \text { localización débil }\end{array}$ \\
\hline $\begin{array}{l}\text { Coeficiente de } \\
\text { Asociación } \\
\text { Geográfica (CAG) }\end{array}$ & $\begin{array}{l}\text { sector } i \quad \text { sector } k=C A G_{i k} \\
\quad \llbracket\left[\left[E_{i j} / \Sigma_{i} E_{i j}\right]-\left[E_{i j} / \Sigma_{k} E_{i j}\right] \rrbracket\right.\end{array}$ & $\begin{array}{c}0,34 \leq \mathrm{CAG} \leq 0,00=\text { Asociación significativa } 0,68 \leq \\
\mathrm{CAG} \leq 0,35=\text { Asociación media } 1,04 \leq \mathrm{CAG} \leq 0,69= \\
\text { Asociación débil }\end{array}$ \\
\hline $\begin{array}{c}\text { Empleo Básico y No } \\
\text { Básico) }\end{array}$ & $B_{i j}=S_{i j}-S_{t j}\left(\frac{N_{i}}{N_{t}}\right)$ & $\begin{array}{l}\text { En la actividad básica el valor mayor que uno será la } \\
\text { rama de actividad más importante del } \\
\text { departamento. }\end{array}$ \\
\hline $\begin{array}{l}\text { Multiplicador de } \\
\text { Empleo Básico }\end{array}$ & $\begin{array}{c}\mathrm{EN}=\alpha \mathrm{E} \text { para }(0>\mathrm{a}>1) \mathrm{E}=\alpha \mathrm{E}+\mathrm{EB} \\
\mathrm{EB}=\mathrm{E}(1-\alpha) \mathrm{E}=1 / 1-\alpha \mathrm{EB} \text { o } \mathrm{E}= \\
\mathrm{KEB}\end{array}$ & $\begin{array}{c}\text { A cada puesto de empleo generado en la actividad } \\
\text { básica }(\mathrm{X}+1) \text { unidad de empleo en la actividad no } \\
\text { básica del departamento. }\end{array}$ \\
\hline
\end{tabular}
actividad productiva no está relativamente concentrada en la unidad territorial (ALVES, 2012; PIFFER, 2012).

Cuadro 1 - Medidas de Localización y multiplicador del empleo 
El CAG muestra la asociación geográfica entre dos sectores (i e k) comparando las distribuciones porcentuales de la mano de obra entre los departamentos. Sus valores varían de cero (0) a uno (1). Cuando adquiere valores próximos a cero, significa que el sector i estará distribuido regionalmente de la misma forma que el sector $\mathrm{k}$, evidenciando que los patrones de localización de los sectores están asociados geográficamente (ALVES, 2012).

Según Lira y Quiroga (2009) Dentro del análisis regional la base económica es representada por la producción exportable, bajo el supuesto de que los sectores con CL $>1$ muestran una especialización relativa, en este orden de ideas existen también las actividades no básicas que según Piffer et al. (2002) son aquellas que producen bienes y servicios para el consumo interno. Por otro lado, existe el cálculo del multiplicador del empleo básico, el cual indica los componentes necesarios para formar la base económica. Piffer (2009) describe la forma como se deben calcular los empleos básicos y no básicos en determinada región tal como aparece en el cuadro 1: $B_{i j}$ es el empleo básico de la actividad i en la región j, $S_{i j}$ es el empleo en la actividad i en le región j, $S_{t j}$ es el empleo total en la región j, $N_{i}$ es el total del empleo en la actividad i en el país y $N_{t}$ es el total de empleos en el país. Si existiera alguna relación entre el empleo y las actividades básicas de exportación, entonces, $B_{i j}$ será mayor que uno.

Finalmente, el multiplicador del empleo básico que es utilizado para medir el impacto del empleo básico en cada departamento. Según el cuadro 1 se observa que: (EM) es el empleo no básico, (EB) es el empleo básico, $(\alpha)$ es el coeficiente del empleo, E es el empleo total, y (K) es el multiplicador de empleo de la región analizada. El multiplicador del empleo muestra cuantos empleos son generados en la rama de actividad no básica dado el aumento de un empleo en los ramos de actividades básicas (PIFFER, 2009).

\section{UBICACIÓN GEOGRÁFICA DE LA REGIÓN AMAZORINOQUIA}

Para realizar el análisis regional se ha seleccionado la región Amazorinoquia de Colombia compuesta por las 8 ciudades principales que representan la economía de cada departamento: Arauca (Arauca), Casanare (Yopal), Putumayo (Mocoa), Amazonas (Leticia), Guainía (Inírida), Guaviare (San José del Guaviare), Vaupés (Mitú) e Vichada (Puerto Carreño), véase la figura 1.

Figura 1. Ubicación geográfica de la región Amazorinoquia por departamentos colombianos y su respectiva capital.

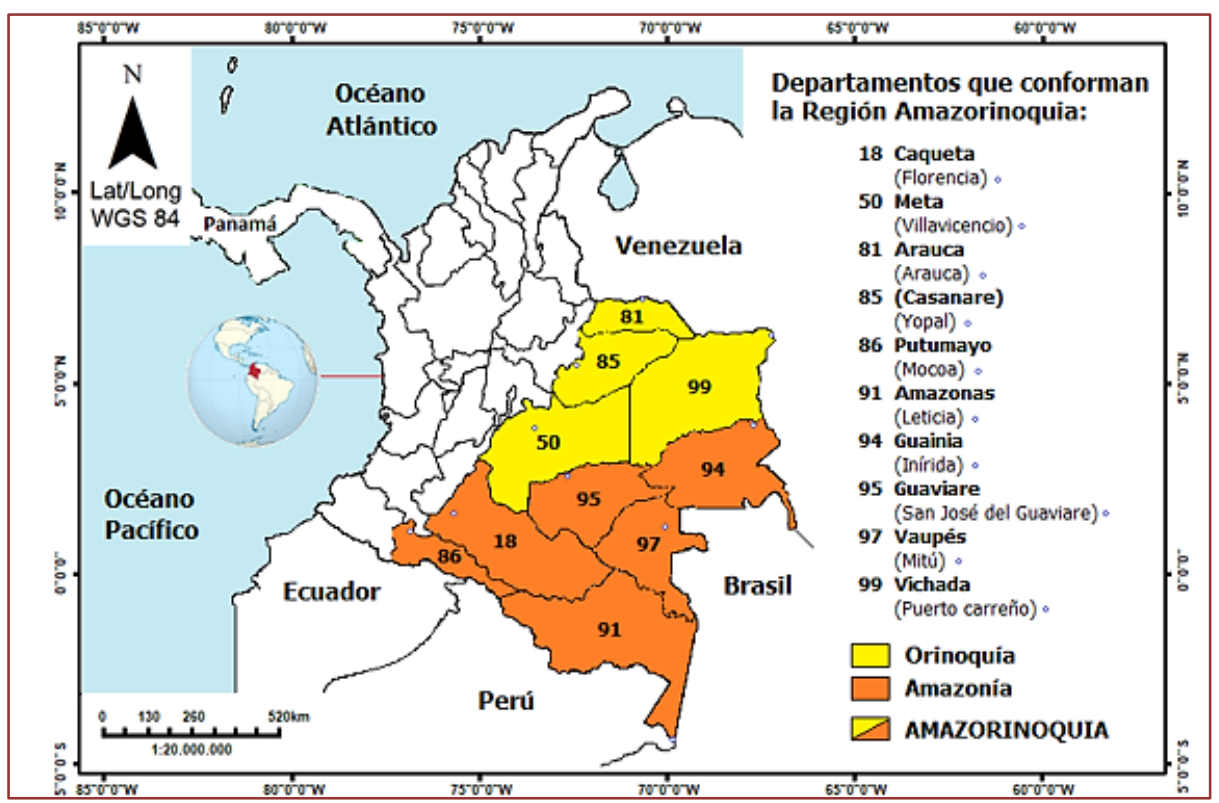

* No contempla los departamentos de Meta* y Caquetá**, porque no sería adecuado compararlos a los 8 departamentos restantes que son relativamente más recientes, dado que fueron creados en 1991.

Fuente: Elaboración propia. 


\section{LOCALIZACIÓN DE LOS SECTORES DENTRO DE LA GEOECONOMIA COLOMBIANA}

En esta sección se discuten los principales resultados del análisis regional de los 8 departamentos colombianos representados por su ciudad capital. La tabla 1 muestra los cocientes de localización para diez sectores económicos. Los sectores o ciudades con un cociente de localización mayor que la unidad, representan aquellas actividades con mayor especialización, es decir, actividades base que son el motor de la economía local en términos del empleo. Los sectores fueron enumerados de la siguiente forma: 1) Agricultura, ganadería, caza, silvicultura y pesca, 2) Explotación de Minas y Canteras, 3) Industria manufacturera, 4) Suministro de Electricidad Gas y Agua, 5) Construcción 6) Comercio, hoteles y restaurantes, 7) Transporte, almacenamiento y comunicaciones, 8) Intermediación financiera, 9) Actividades inmobiliarias, empresariales y de alquiler, y 10) Servicios comunales, sociales y personales.

Tabla 1 - Cociente de Localización (CL) 8 ciudades en la región Amazorinoquia de Colombia

\begin{tabular}{|c|c|c|c|c|c|c|c|c|c|c|c|c|c|c|c|c|c|c|c|c|}
\hline \multirow{2}{*}{$\begin{array}{c}\text { Sectores } \\
\text { Dtos }\end{array}$} & \multicolumn{2}{|c|}{$\begin{array}{c}\text { 1. Agricultura, } \\
\text { ganadería, } \\
\text { caza, } \\
\text { silvicultura y } \\
\text { pesca }\end{array}$} & \multicolumn{2}{|c|}{$\begin{array}{l}\text { 2. Explotación } \\
\text { de Minas y } \\
\text { Canteras }\end{array}$} & \multicolumn{2}{|c|}{$\begin{array}{c}\text { 3. Industria } \\
\text { manufacturer } \\
\text { a }\end{array}$} & \multicolumn{2}{|c|}{$\begin{array}{l}\text { 4. Sum inistro } \\
\text { de } \\
\text { Electricidad } \\
\text { Gas y Agua }\end{array}$} & \multicolumn{2}{|c|}{$\begin{array}{c}5 . \\
\text { Construcción }\end{array}$} & \multicolumn{2}{|c|}{$\begin{array}{l}\text { 6. Comercio, } \\
\text { hoteles y } \\
\text { restaurantes }\end{array}$} & \multicolumn{2}{|c|}{$\begin{array}{c}\text { Transporte, } \\
\text { almacenamie } \\
\text { nto y } \\
\end{array}$} & \multicolumn{2}{|c|}{$\begin{array}{c}8 . \\
\text { Intermediaci } \\
\text { ón financiera }\end{array}$} & \multicolumn{2}{|c|}{$\begin{array}{l}\text { Actividades } \\
\text { inmobiliarias, } \\
\text { empresariale }\end{array}$} & \multicolumn{2}{|c|}{$\begin{array}{c}\text { 10. Servicios } \\
\text { comunales, } \\
\text { sociales y } \\
\text { personales }\end{array}$} \\
\hline & 2012 & 2017 & 2012 & 2017 & 2012 & 2017 & 2012 & 2017 & 2012 & 2017 & 2012 & 2011 & 2012 & 2017 & 2012 & 2017 & 2012 & 2017 & 2012 & 2017 \\
\hline 81 & 1,30 & 95 & 1,12 & 1,88 & 0,83 & 0,85 & 0,79 & 0,88 & 1,03 & 1,21 & 0,99 & 1,00 & 1,10 & 0,71 & U,ou & 1,00 & 1,00 & 1,05 & 0,97 & 1,00 \\
\hline 85 & 0,63 & 0,77 & 1,65 & 1,32 & 1,09 & 1,13 & 0,87 & 1,19 & 1,25 & 1,05 & 1,04 & 1,05 & 1,02 & 1,09 & 1,07 & 1,06 & 1,27 & 1,27 & 0,79 & 0,81 \\
\hline 86 & & 74 & &, 48 & 1,03 & & & 1,11 & 0,99 & 1,01 & & & 0,65 & 0,79 & & 1,69 & 1,08 & & & 1,22 \\
\hline 91 & 47 & 0,61 & & 0 & 1,04 & 70 & 1,0 & 1,10 & 0,63 & 0,78 & & 1,12 & 1,22 & 1,50 & & 0,92 & 0,71 & 0,44 & 10 & 1,07 \\
\hline 94 & 2,20 & 2,57 & 0,40 & 0,78 & 0,90 & 0,90 & 1,14 & 0,54 & 0,81 & 1,05 & 0,74 & 0,75 & 0,97 & 1,55 & 1,15 & 0,58 & 0,52 & 0,51 & 1,38 & 1,14 \\
\hline 95 & 1,46 & 1,77 & 0,12 & 0,34 & 1,10 & 1,43 & 1,55 & 0,75 & 0,53 & 0,78 & 1,13 & 1,00 & 0,82 & 0,83 & 1,25 & 0,55 & 0,66 & 0,72 & 1,08 & 1,06 \\
\hline 97 & 1,29 & 0,24 & 0,65 & 0,20 & 0,67 & 0,41 & 1,32 & 0,40 & 0,82 & 0,85 & 0,63 & 0,68 & 1,22 & 1,25 & 0,56 & 0,82 & 0,36 & 0,27 & 1,63 & 1,82 \\
\hline 99 & 2,62 & 1,66 & 0,13 & 0,00 & 0,93 & 0,74 & 1,55 & 0,80 & 0,96 & 0,73 & 0,76 & 0,87 & 0,97 & 0,89 & 0,65 & 0,87 & 0,71 & 0,63 & 1,22 & 1,38 \\
\hline
\end{tabular}

Fuente: Resultados de la investigación

El sector de la agricultura, ganadería, caza, silvicultura y pesca (1) presentó en el año 2012 cinco departamentos con CL $\geq 1$ entre los cuales se encuentran: Arauca (81), Guainía (94), Guaviare (95), Vaupés (97) y Vichada (99), Guainía tiene el coeficiente de localización más alto entre todos los sectores y territorios 2,20 y alcanzo 2,57 en 2017. Para el 2017 la agricultura dejo de ser actividad base en Vaupés (97) y medianamente en Arauca (81).

Figura 2. CL de la Agricultura, ganadería, caza y silvicultura de la región Amazorinoquia en Colombia 2012 - 2017.

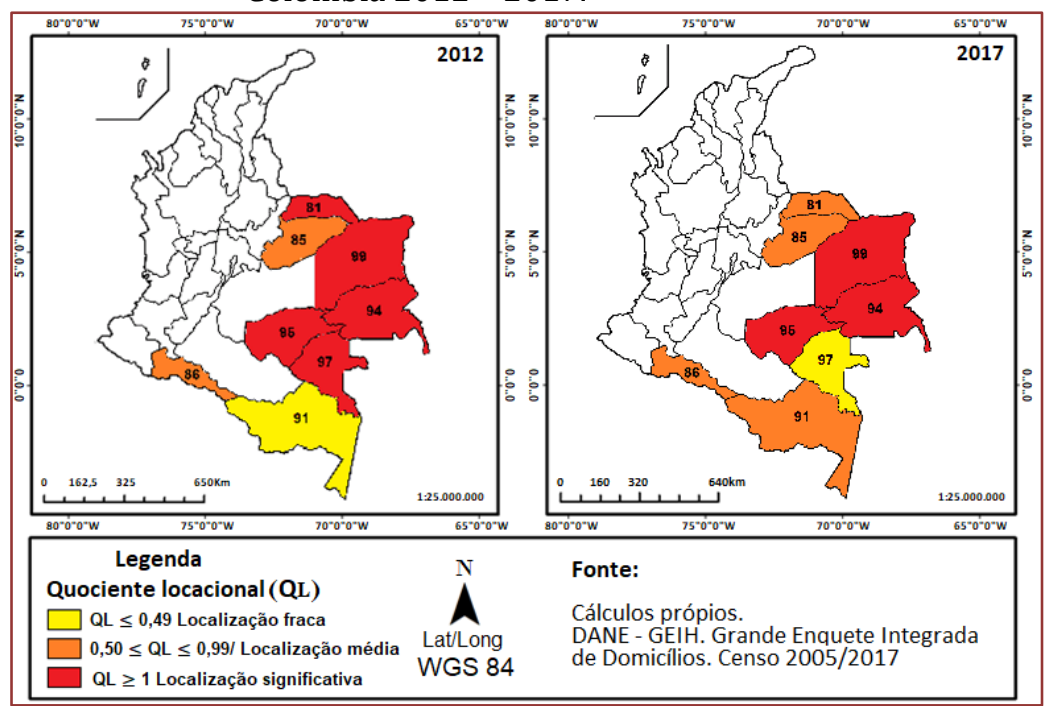

La figura 3 presenta el CL de la explotación de minas y canteras (2). Los departamentos que para los años 2012 y 2017 presentaron CL $\geq 1$ fueron: Casanare (85) y Arauca (81), mientras que Putumayo (86) y Vaupés (97) pasaron de localización media a débil, de 2012 a 2017, respectivamente. 
Figura 3. CL del sector de Exploración de minas y canteras de la región Amazorinoquia en Colombia

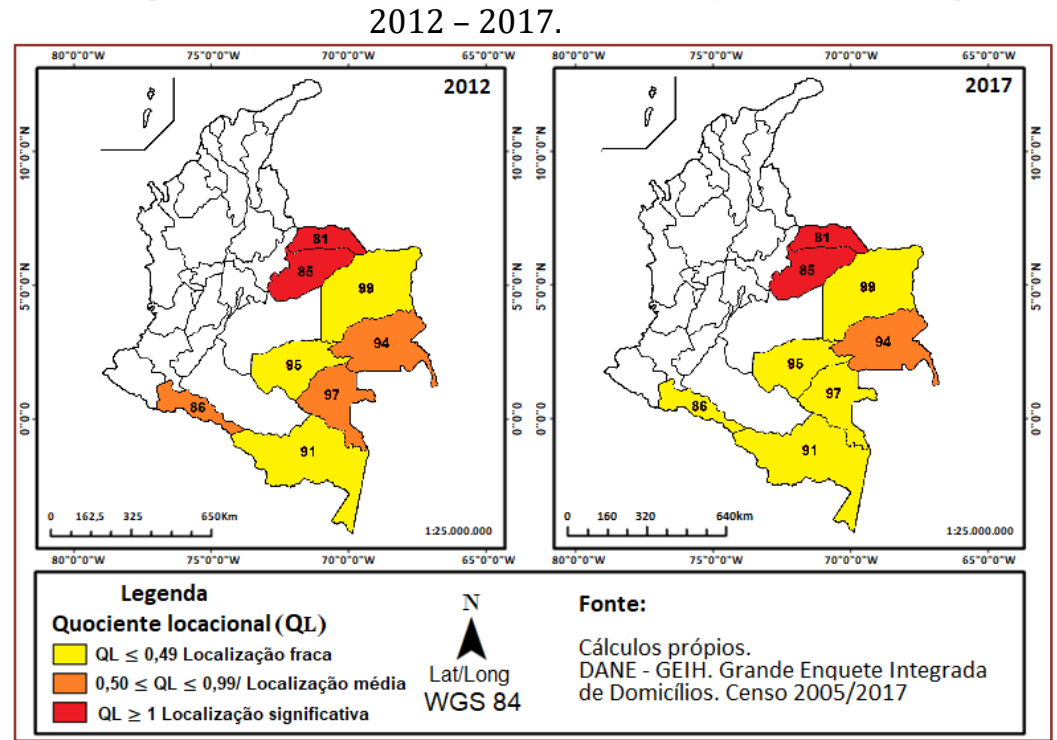

La figura 4 muestra el comportamiento de la industria manufacturera en los 8 departamentos analizados. Para el año 2012, 4 departamentos presentaron cociente de localización $\geq 1$ siendo estos: Casanare (85), Putumayo (86), Amazonas (91) y Guaviare (95). Para el año 2017 el sector de la industria decrece en dos de los cuatro departamentos anteriores: Putumayo (86) y Amazonas (91).

Figura 4. CL del sector Industria manufacturera de la región Amazorinoquia en Colombia 2012 -

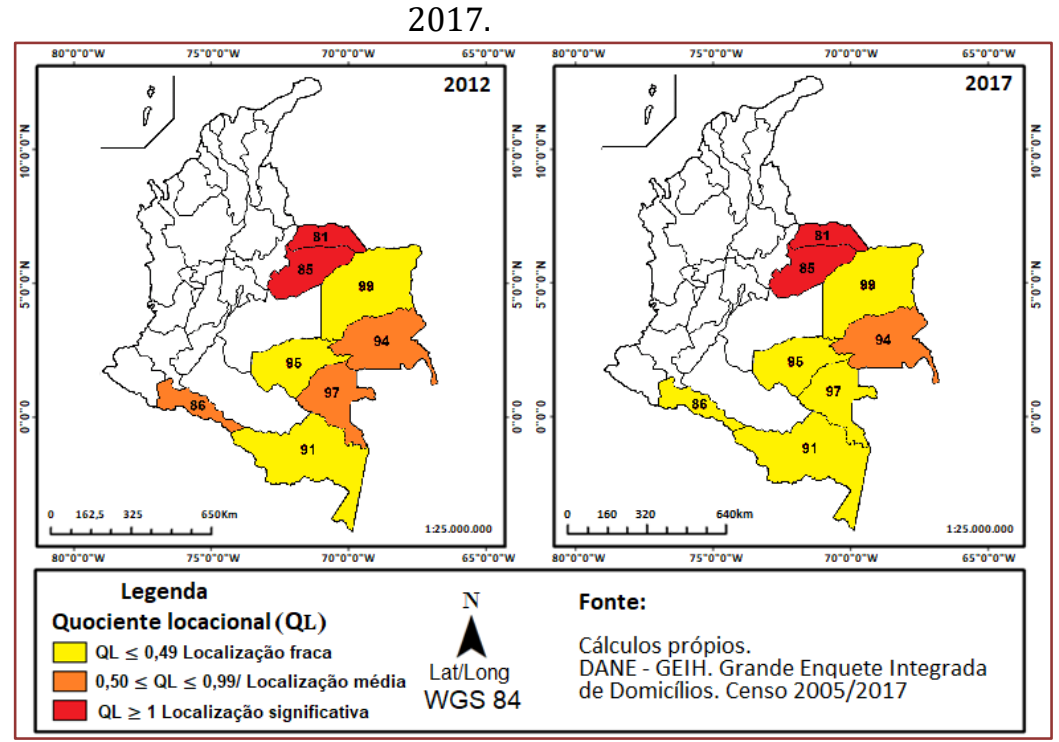

En la figura 5 se presenta el CL del sector Suministro de Electricidad Gas y Agua de 2012 y 2017. Se puede afirmar que es un sector significativo en 2012, sin embargo, en 2017 deja de serlo en Vichada (99), Guainía (94), Guaviare (95) y fuertemente decae en Vaupés (97), mientras para Casanare (85) y Putumayo (86) ahora está fuertemente concentrado. 
Figura 5. CL del sector Suministro de Electricidad Gas y Agua de la región Amazorinoquia en Colombia 2012 - 2017.

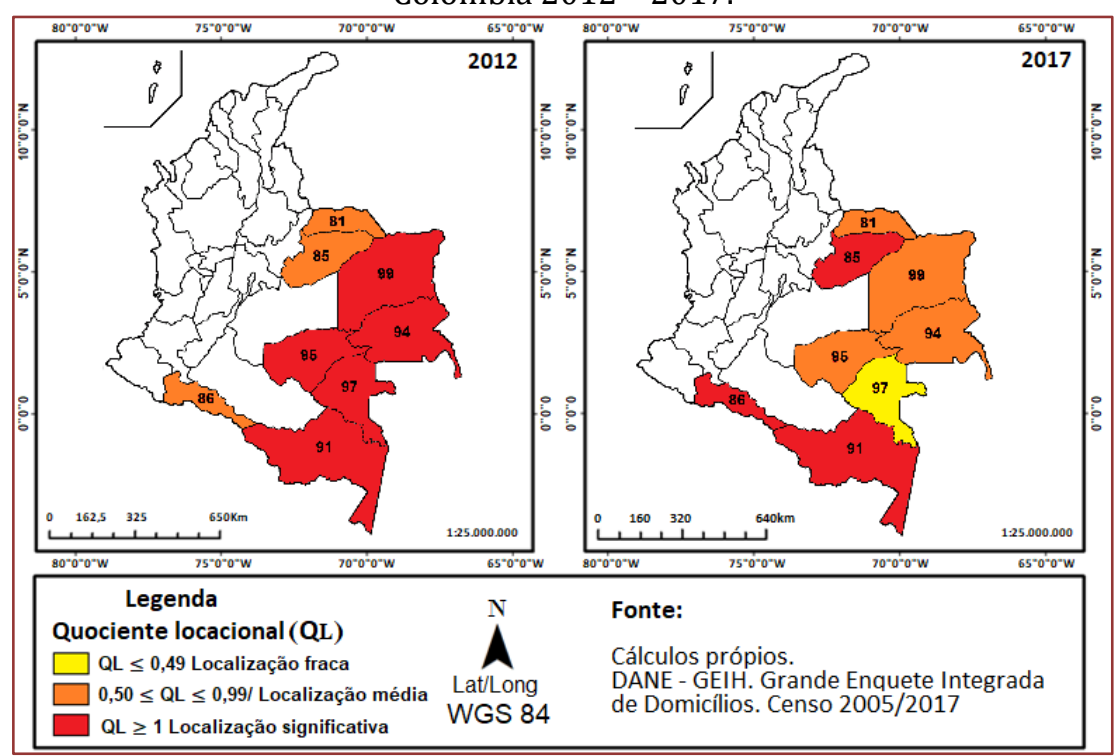

El sector construcción representado en la figura 6 es la actividad básica de Arauca (81), Casanare (85) y Putumayo (86) en 2012 y en 2017 se vincula Guainía (94), en el resto de departamentos la construcción no está relativamente especializada en el territorio.

Figura 6. CL del sector Construcción de la región Amazorinoquia en Colombia 2012 - 2017.

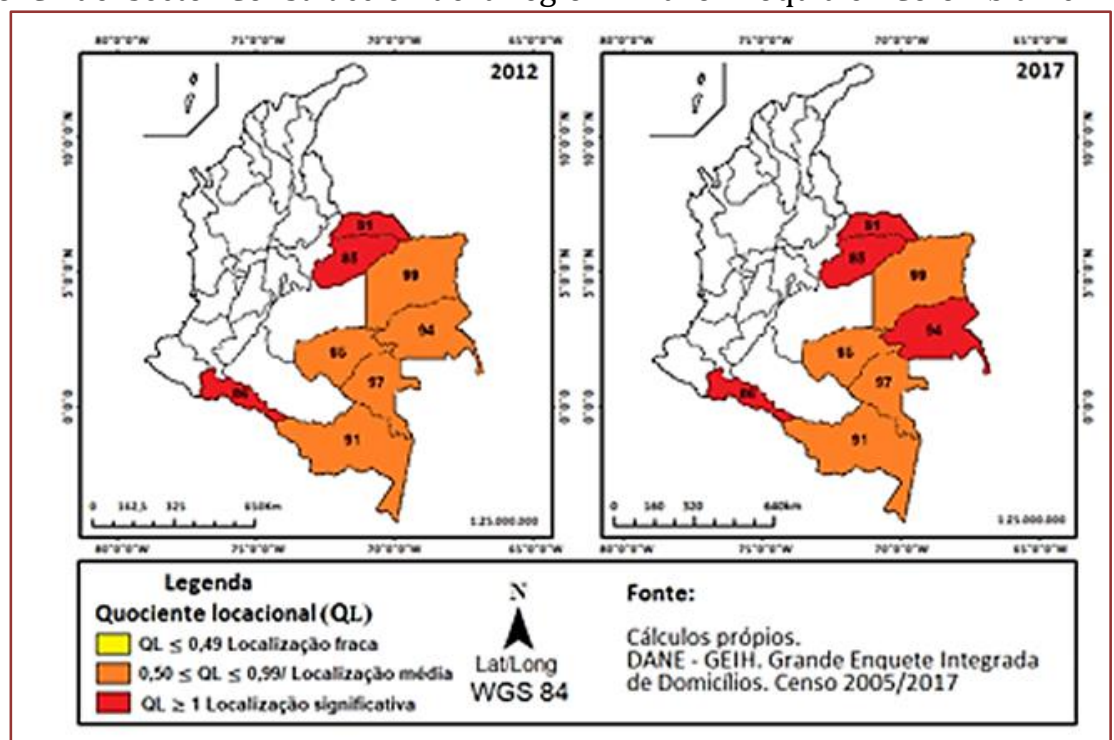

La figura 7 muestra los cambios existentes entre los años 2012 y 2017 en el sector de comercio, hoteles y restaurante. De los 8 departamentos analizados la mitad presentaron CL menor a la unidad tanto en 2012 como en 2017, siendo estos Putumayo (86), Guainía (94), Vaupés (97) y Vichada (99).

Mientras para Arauca (81), Casanare (85), Amazonas (91) y Guaviare (95), el Comercio es su actividad básica. Según Avila (2009) y Avila, Gavidia (2010), tras el desmonte de las regalías petroleras en 2011, este sector surgió como respuesta a la crisis de recursos económicos representando en varios de los nuevos departamentos el $70 \%$ de su renta. 
Figura 7. CL del sector Comercio, hoteles y restaurantes de la región Amazorinoquia en Colombia 2012 - 2017.

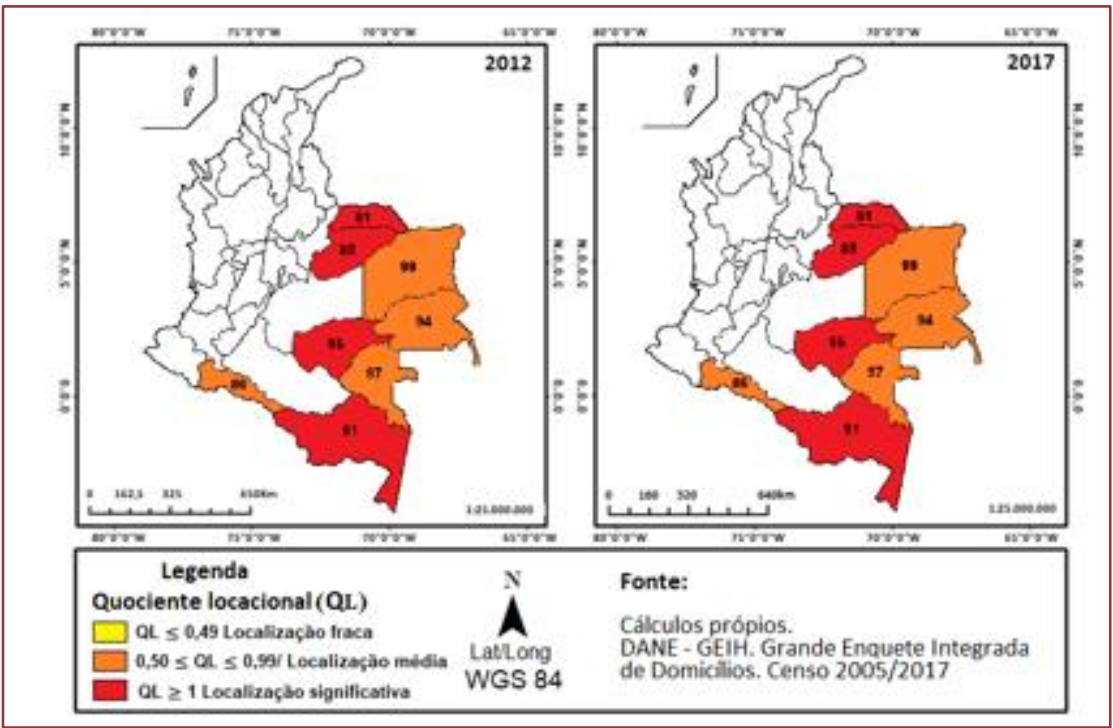

El sector Transporte, almacenamiento y comunicaciones tanto en 2012 como en 2017 ha sido la actividad básica de Casanare (85), Amazonas (91) y Vaupés (97), véase la figura 8. Así mismo, este sector en 2017 fue básico con Guainía (94) y dejo de serlo en Arauca (81).

Figura 8. CL del sector Transporte, almacenamiento y comunicaciones de la región Amazorinoquia en Colombia 2012 - 2017.

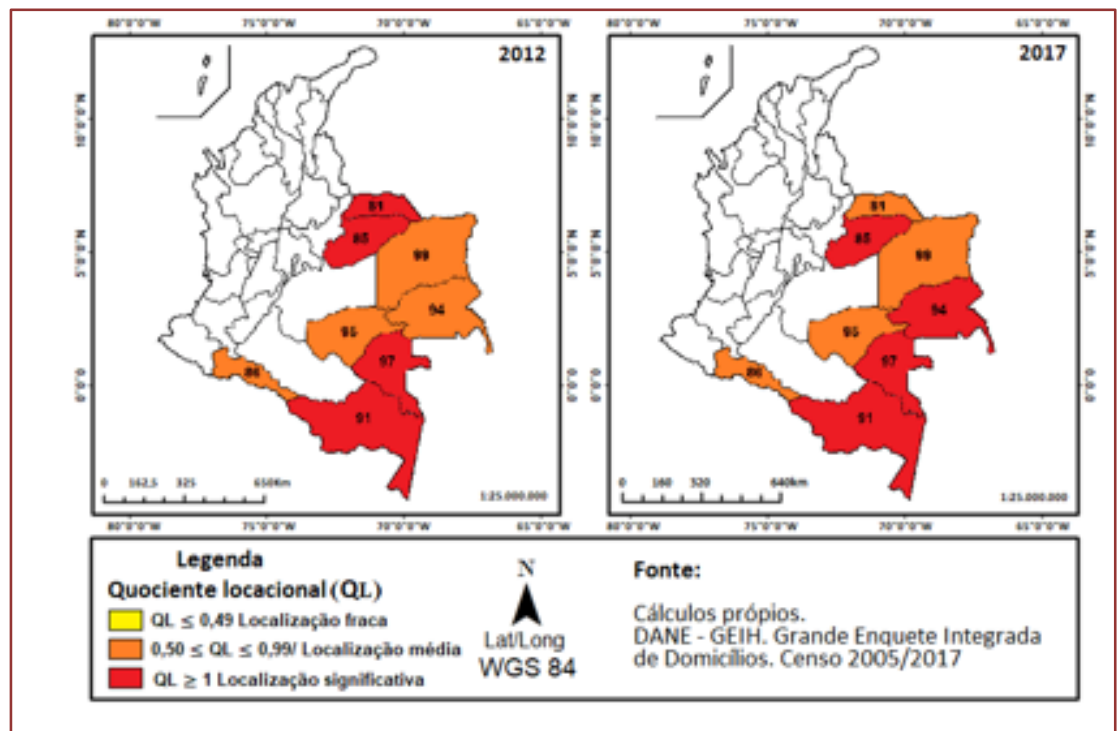

El sector de Intermediación financiera según muestra la figura 9 fue significativo en 2012 para los departamentos nuevos de Amazonas (91), Guainía (94) y Guaviare (95), pero no para el 2017. Casanare (85) mantuvo este sector como actividad básica y en 2017 también los nuevos departamentos de Arauca (81) y Putumayo (86) se especializaron. 
Figura 9. CL del sector de Intermediación financiera de la región Amazorinoquia en Colombia 2012 $-2017$.

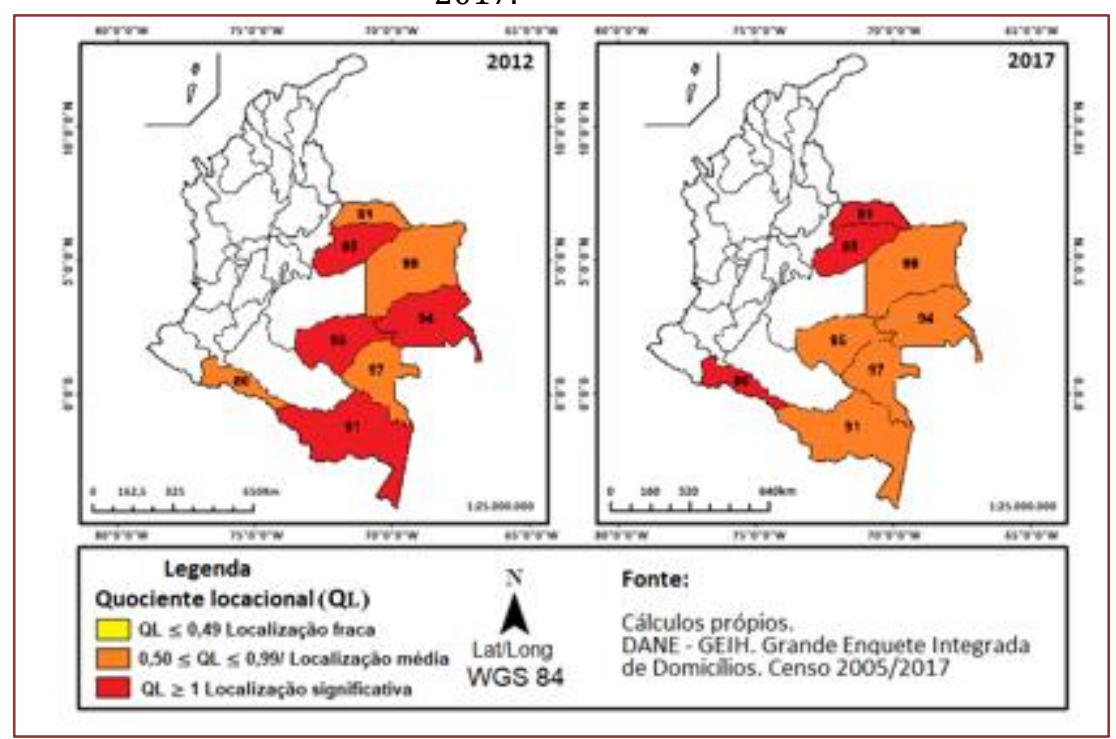

Otro sector con poca especialidad en Colombia durante el periodo analizado es el de Actividades inmobiliarias, empresariales y de alquiler. Solo tres departamentos nuevos en 2012 y 2017 presentaron un CL $\geq 1$; Arauca (81), Casanare (85) y Putumayo (86). Para el año 2017 el departamento de Amazonas (91) redujo aún más su participación frente al orden nacional, pasando de localización media a débil.

Figura 10. CL del sector Actividades inmobiliarias, empresariales y de alquiler de la región Amazorinoquia en Colombia 2012 - 2017.

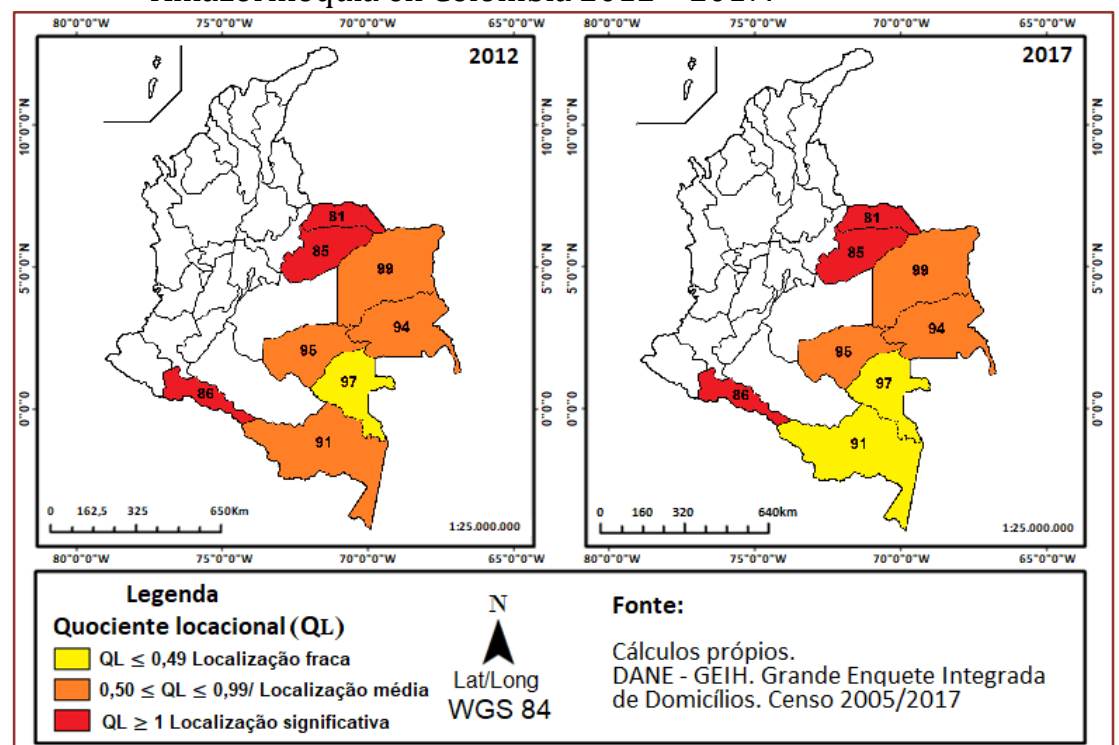

En cuanto al sector de Servicio público, social y personal, es la actividad productiva más especializada en la región amazorinoquia a excepción del departamento de Casanare (85) aunque alcanzó un $\mathrm{CL}=0,81$ en 2017. 
Figura 11. Cl del sector Servicios Comunales, sociales y personales de la región Amazorinoquia en Colombia 2012 - 2017.

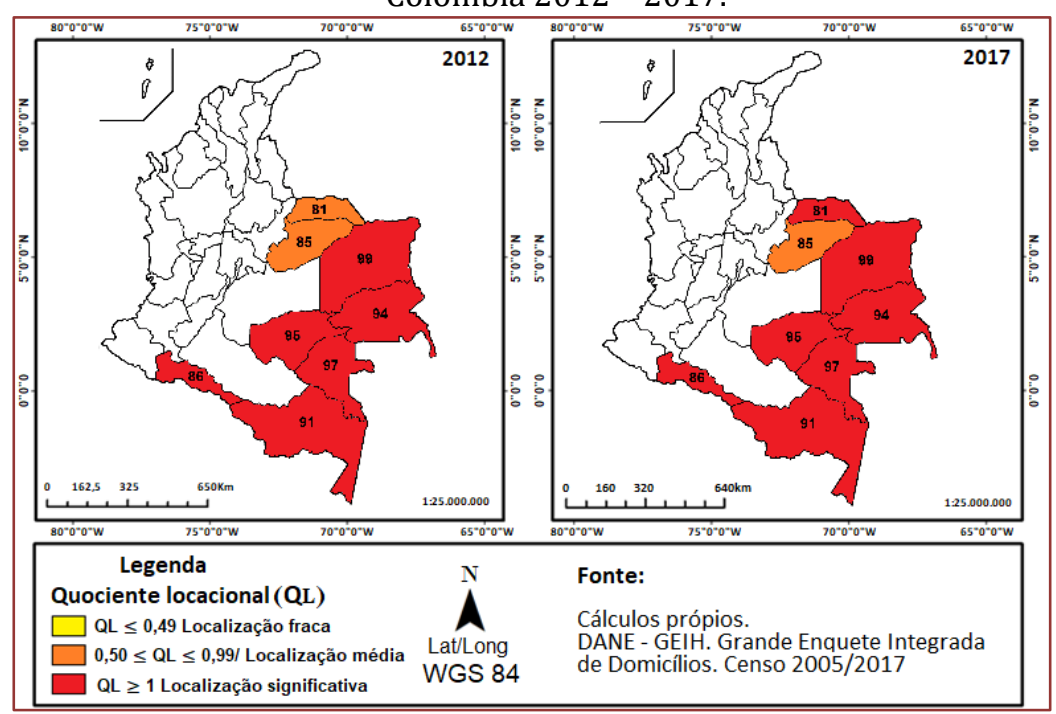

En este orden de ideas, teniendo en cuenta las figuras 2-11; a manera de conclusión preliminar, se puede definir que 7 de los 8 departamentos medidos a través de sus ciudades capitales en 2017 tienen el sector Servicios Comunales, sociales y personales como uno de sus motores de crecimiento. Mientras que los sectores que registran la menor participación en los departamentos son Exploración de minas y canteras, e Industria manufacturera, debido a que solo se encuentran especializados en 2 nuevos departamentos (Casanare y Arauca) y aunque las ramas de actividad económica de Agricultura, agropecuaria, caza, silvicultura y pesca; Construcción; Comercio, hoteles y restaurantes y Transporte se encuentran especializadas en 4 departamentos, solo el sector de agricultura posee una ciudad capital donde el CL es mayor a 2,5 (Inírida - Guainía 94).

Así mismo, de los 8 departamentos, sobresale como líder regional el departamento de Casanare (Yopal) con 8 de los 10 sectores como actividades base en su economía, seguido por Arauca y Putumayo con 6 y 5, respectivamente. Mientras los departamentos de Vaupés y Vichada son significativos por ser los de menor especialización en sus ramas de actividad económica, con solo 2 de ellas. También están Amazonia, Guainía y Guaviare, entre los departamentos nuevos con 4 actividades de base cada uno.

Después de realizar la estimativa del cociente de localización para la región Amazorinoquia de Colombia, fue estimado el Multiplicador del empleo con base en los valores del empleo básico y no básico en relación con el país, para el año 2012 y 2017 (tabla 2). Los valores presentes en esta tabla apuntan que: en el 2012 la ciudad que presentó mayor multiplicador de empleo fue Arauca, capital del nuevo territorio de Arauca (81) con 14,32 evidenciando las condiciones que las principales actividades tienen para incentivar la generación de renta y empleo local. En otras palabras, cada empleo básico en el departamento estimula la generación de aproximadamente 14 puestos de trabajo en el sector no básico. Esto significa que los empleos básicos corresponden al 14,32\% de los empleos totales y que los empleos no básicos corresponden al 85,68\% del total.

No obstante, el multiplicador del empleo para Arauca en 2017 cae a 8,71, siendo el departamento con la caída porcentual más alta 5,6 hecho que se evidenciaba al dejar de tener como motores de crecimiento regional los sectores de agricultura y de Transportes.

De igual forma, los departamentos que más crecieron del 2012 al 2017 fueron Guaviare y Casanare, pasando de 10,39 a 14,7 y de 10,35 a 11,44, respectivamente. Levemente crecieron Guainía y Vichada (menos de un punto) y el departamento con el nivel más bajo en la generación de empleo es Vaupés con 3,54; cada empleo básico en el departamento estimula la generación de aproximadamente 3-4 puestos de trabajo en el sector no básico. 
Tabla 2. Multiplicador de empleo de los departamentos de la región Amazorinoquia en Colombia 2012 - 2017.

\begin{tabular}{|c|l|c|c|c|}
\hline Cód. & Território & Cidade Capital & $\mathbf{2 0 1 2}$ & $\mathbf{2 0 1 7}$ \\
\hline $\mathbf{8 1}$ & Arauca & Arauca & 14,32 & 8,71 \\
\hline $\mathbf{8 5}$ & Casanare & Yopal & 10,35 & 11,44 \\
\hline $\mathbf{8 6}$ & Putumayo & Mocoa & 9,80 & 7,03 \\
\hline $\mathbf{9 1}$ & Amazonas & Leticia & 9,58 & 6,27 \\
\hline $\mathbf{9 4}$ & Guainía & Inírida & 4,87 & 5,68 \\
\hline $\mathbf{9 5}$ & Guaviare & San José del Guaviare & 10,39 & 14,70 \\
\hline $\mathbf{9 7}$ & Vaupés & Mitú & 3,99 & 3,54 \\
\hline $\mathbf{9 9}$ & Vichada & Puerto Carreño & 5,65 & 5,77 \\
\hline
\end{tabular}

Fuente: Resultados de la investigación

Finalmente, el coeficiente de asociación geográfica presentado en la tabla 3 puede ser analizado dentro de los siguientes intervalos: $0,34 \leq$ Cag $\leq 0,00=$ Asociación significativa; 0,68 $\leq$ Cag $\leq 0,35=$ Asociación media; 1,04 $\leq$ Cag $\leq 0,69=$ Asociación débil $-\left(^{*}\right)$ Asociación total. En ese sentido, para el año 2012 y 2017 todas las ramas de actividad económicas entre sí tienen asociación significativa, a excepción del sector Exploración de minas y canteras frente a los sectores de Agricultura, agropecuaria, caza, silvicultura y pesca y a Servicio público, social y personal, dado que presenta una asociación media con 0,37 y 0,36 , respectivamente (véase la tabla 4).

Es decir, que la región Amazorinoquia ${ }^{5}$ posee un grupo de nuevos departamentos con sectores fuertemente complementarios en su proceso productivo. Debido a que la existencia de un sector exige la existencia de otro sector para que ocurra el proceso productivo con mayor eficiencia.

Tabla 4. Coeficiente de Asociación geográfica en los nuevos departamentos de Colombia

\begin{tabular}{|c|c|c|c|c|c|c|c|c|c|c|c|c|c|c|c|c|c|c|c|c|}
\hline \multirow[t]{2}{*}{ Sectores } & \multicolumn{2}{|c|}{$\begin{array}{c}\begin{array}{c}\text { Agrieultura, } \\
\text { ga naderia, } \\
\text { caxa, } \\
\text { gilvie ultura y } \\
\text { pexea }\end{array} \\
\end{array}$} & \multicolumn{2}{|c|}{$\begin{array}{c}\text { 2. Explotaclon } \\
\text { de Minas y } \\
\text { Canteras }\end{array}$} & \multicolumn{2}{|c|}{$\begin{array}{l}\text { 3. Industrla } \\
\text { manufacturer } \\
\text { a }\end{array}$} & \multicolumn{2}{|c|}{\begin{tabular}{|c|} 
4. Suministro \\
do \\
Bectricldad \\
Gas y Agua \\
\end{tabular}} & \multicolumn{2}{|c|}{$\begin{array}{c}5 . \\
\text { Construccion }\end{array}$} & \multicolumn{2}{|c|}{$\begin{array}{c}\text { 6. Comerclo, } \\
\text { hotelas y } \\
\text { restaurantes }\end{array}$} & \multicolumn{2}{|c|}{$\begin{array}{c}7 . \\
\text { Trans porte, } \\
\text { almacenamis } \\
\text { ntby } \\
\end{array}$} & \multicolumn{2}{|c|}{$\begin{array}{c}8 . \\
\text { Intermediacl } \\
\text { on financlera }\end{array}$} & \multicolumn{2}{|c|}{\begin{tabular}{|c|}
9. \\
Actividades \\
Inmob!rarlas. \\
empresarlals
\end{tabular}} & \multicolumn{2}{|c|}{$\begin{array}{l}\text { 10. Servicios } \\
\text { comunales, } \\
\text { soclalas y } \\
\text { personales }\end{array}$} \\
\hline & 2012 & 2017 & 2012 & 2017 & 2012 & 2017 & 2012 & 2017 & 2012 & 2017 & 2012 & 2017 & 2012 & 2017 & 2012 & 2017 & 2012 & 2017 & 2012 & 2017 \\
\hline 1 & $*$ & $*$ & & & & & & & & & & & & & & & & & & \\
\hline 2 & 0,40 & 0,39 & $*$ & $*$ & & & & & & & & & & & & & & & & \\
\hline 3 & 0,27 & 0,16 & 0,28 & 0,26 & * & * & & & & & & & & & & & & & & \\
\hline 4 & 0,18 & 0,25 & 0,37 & 0,24 & 0,11 & 0,11 & $\approx$ & $\approx$ & & & & & & & & & & & & \\
\hline 5 & 0,29 & 0,22 & 0,18 & 0,23 & 0,11 & 0,12 & 0,20 & 0,09 & $\approx$ & $=$ & & & & & & & & & & \\
\hline 6 & 0,24 & 0,19 & 0,26 & 0,26 & 0,04 & 0,10 & 0,12 & 0,08 & 0,11 & 0,06 & $*$ & $*$ & & & & & & & & \\
\hline 7 & 0,22 & 0,23 & 0,25 & 0,30 & 0,10 & 0,12 & 0,14 & 0,10 & 0,12 & 0,11 & 0,07 & 0,09 & * & * & & & & & & \\
\hline 8 & 0,28 & 0,26 & 0,30 & 0,27 & 0,03 & 0,16 & 0,09 & 0,10 & 0,14 & 0,09 & 0,05 & 0,09 & 0,11 & 0,14 & $*$ & $*$ & & & & \\
\hline 9 & 0,31 & 0,26 & 0,18 & 0,17 & 0,11 & 0,14 & 0,22 & 0,07 & 0,04 & 0,10 & 0,11 & 0,12 & 0,14 & 0,17 & 0,14 & 0,12 & $\approx$ & $*$ & & \\
\hline 10 & 0,19 & 0,15 & 0,36 & 0,36 & 0,12 & 0,18 & 0,10 & 0,16 & 0,19 & 0,14 & 0,11 & 0,10 & 0,12 & 0,16 & 0,13 & 0,15 & 0,19 & 0,20 & $*$ & $*$ \\
\hline
\end{tabular}

Fuente: resultados de la investigación

No obstante, aunque la relación Exploración de minas y canteras con Agricultura es media, estos resultados evidencian el fuerte impacto que tienen el sector Exploración de minas y canteras en la economía colombiana. Según Galvis (2014) en su estudio sobre la economía colombiana encuentra que algunos departamentos dedicados a la extracción de petróleo pueden ser denominados departamentos ricos y entre ellos se encuentran dos nuevos departamentos; Casanare con el de mayor PIB per cápita de Colombia y Arauca. Sin embargo, siguiendo a Avila, Oliveira (2018) tras el decreto Ley 1530 de 2012 que regula la organización y el funcionamiento del Sistema General de Regalías -SGR, los productores de crudo ya no disponen de dichos recursos, ahora están centralizados, por lo que se evidencio como respuesta al desmonte de estos recursos que se diera el crecimiento del sector Comercio en estas zonas.

5 Recordando que están exceptuados los departamentos de Meta y Caquetá en Colombia, porque estos departamentos no son relativamente nuevos. Es decir, creados en la constituyente de 1991. 


\section{CONCLUSIONES}

Teniendo en cuenta los CL de todos los sectores se evidencia que la rama de actividad económica con especialización significativa que más aporta en la participación de empleo regional es el sector Servicio público, social e personal, dado que es uno de los motores de crecimiento en 7 de los 8 departamentos. Mientras que los sectores que registran la menor participación son Exploración de minas y canteras junto a Industria manufacturera, debido a que solo se encuentran especializados en 2 nuevos departamentos.

Entre los departamentos de la Región Amazorinoquia de Colombia, Casanare (medido a través de su capital Yopal) sobresale como el líder regional al tener 8 sectores de los 10 como actividades base en su economía, seguido por los departamentos de Arauca y Putumayo con 6 y 5 sectores, respectivamente. Mientras los departamentos de Vaupés y Vichada son significativos por ser los de menor especialización en sus ramas de actividad económica, con solo 2 de ellas.

Según el multiplicador de empleo entre los departamentos de la Amazorinoquia, la ciudad capital donde cada puesto de trabajo básico genera más de 14,7 empleos no básicos es San José del Guaviare, seguida por Yopal (Casanare) con 11,4 en 2017. Mientras Mitú (Vaupés) es la ciudad con menor proporción de empleos básicos totales y la mayor con no básicos con el 3,99 \% y 96\% a 3,54\% y 96,5\% en 2012 y 2017 respectivamente.

Todos los sectores en la economía de los departamentos de la Amazorinoquia colombiana según los coeficientes de asociación geográfica a excepción del sector de Explotación de Minas y canteras están concentrados. Debido a que todos los sectores tienen una distribución sectorial muy similar, se evidencia que los patrones de localización de los sectores están asociados geográficamente.

Los ocho departamentos de Colombia, medidos a través de sus capitales poseen una dualidad relevante en su sistema productivo, en el que la minería fue fundamental para jalonar económicamente la región Amazorinoquia, estimulando fuertemente el sector de la construcción y tras el desmonte de recursos por regalías en 2011 al sector comercio.

Finalmente, pese a tener el sector Servicios comunales, sociales y personales una alta representatividad en la región Amazorinoquia, en general los cocientes de localización y los coeficientes de asociación geográfica, reflejan que la economía de los nuevos departamentos de Colombia continúa dependiendo de 3 actividades básicas: una actividad primaria (Agricultura); una secundaria (Construcción) y una terciaria (Comercio, hoteles y restaurantes).

\section{BIBLIOGRAFIA}

[1] Acosta, Ordóñez. Cartagena: entre el progreso industrial y el rezago social. Economía \& Región, Universidad Tecnológica de Bolívar, vol. 7, núm. 1, 2013.

[2] Aguilera, María Bucaramanga: Capital Humano y Crecimiento Económico Revista del Banco de la República, Núm. 180, enero de 2013.

[3] Alves, L. R. Indicadores de localização, especialização e estruturação regional. In: PIACENTI, C. A.; Ferrera DE Lima, J. (orgs.). Análise regional: metodologias e indicadores. Curitiba: Camões, 2012.

[4] Avila, Cristian. Dinámica de la acumulación de capital humano en Yopal, Casanare. Revista Apuntes del CENES, Vol XXVII - Núm 46 Págs. 261-297 marzo, 2009.

[5] Avila, Cristian; Oliveira, Nilton. Desarrollo Y Crecimiento Economico - Casanare", -Lecciones aprendidas, Unad-UFT, 2018.

[6] Avila, Cristian; Gavidia, Wilfredo. Ensayos de economía aplicada en Yopal Casanare, Dinámica demográfica y acumulación de capital humano. Unitrópico - ПАС®OPICO. 2010.

[7] Christaller, Walter. Central places in Southern Germany. New Jersey: Prentice-Hall, 1966.

[8] Departamento Nacional de Estadística, Dane. (2012). Cuentas departamentales-Colombia, Bogotá, Dirección de Síntesis y Cuentas Nacionales, 11 de octubre. Disponible en: https://www.dane.gov.co/index.php/estadisticas-por-tema/cuentas-nacionales/cuentas-nacionalesdepartamentales. Consultado en 26 may 2018.

[9] __Boletín Técnico: Encuesta Anual Manufacturera, 2016. Disponible en: https://www.dane.gov.co/files/investigaciones/boletines/eam/boletin_eam_2016.pdf Consultado en 26 may 2018. 
[10] _ _ - -Banco de la República de Colombia. Informe de Coyuntura Económica Regional. ICER, Departamento de Bolivar, 2016. Disponible en: http://www.banrep.gov.co/icer. Consultado en 24 may 2018.

[11] _ _ Informe de Coyuntura Económica Regional. ICER, Departamento del Atlántico, 2015. Disponible en: http://www.banrep.gov.co/icer. Consultado en 24 may 2018.

[12] Escuela Nacional Sindical (ENS). Sector Financiero y Bancario Colombiano: Características Económicas, Laborales y de Negociación Colectiva, 2015. Disponible en: http://www.ens.org.co/wpcontent/uploads/2016/12/DOCUMENTOS-DE-LA-ESCUELA_100-Sector-financiero-y-bancario-colombianoEcon\%C3\%B3mico-laboral-y-de-negociaci\%C3\%B3n-colectiva-2015.pdf. Consultado en 23 may 2018.

[13] Galvis, Luis (Ed). Economía de las Grandes Ciudades en Colombia: seis estudios de caso. Colección de Economía Regional. Banco de la República. Bogotá, 2014.

[14] Haddad, P. R. (Org.). Economia regional: teoria e métodos de analise. Fortaleza: BNB/Etiene, 1989.

[15] Lira, L.; Quiroga, B. “Técnicas de análisis regional”, Series Manuales, ilpes, Santiago de Chile, 2008.

[16] Marshall, Alfred. (1890). Princípios de Economia. São Paulo: Abril Cultural.

[17] Maldonado, A. Descentralización y desarrollo económico local. Una visión general del caso de Colombia, LC/R.1968, Revista de la Cepal. Santiago de Chile, 2000. Comisión Económica para América Latina y el Caribe (CEPAL)

[18] Myrdal,G. Economic theory and under-developed regions. G.Duckworth, 1957

[19] North, D.C. Location theory and regional economic growth. Journal of Political Economy, v. 63, june

[20] Otero, A. “Cali a comienzos del siglo xxi: ¿crisis o recuperación?”, 2012.

[21] Documentos de Trabajo sobre Economía Regional y Urbana, Banco de la República. Disponible en: http://www.banrep.gov.co/es/node/27943.

[22] Perroux, François. A economia do século XX. Tradução de José Lebre de Freitas. Lisboa: Herder, 1967.

[23] Piffer, M. Indicadores de base econômica. In: Piacenti, C. A.; Ferrera de Lima, J. (Org.). Análise regional: metodologias e indicadores. Curitiba: Camões, 2012. p. 51-62

[24] _ _ et al. A base de exportação e a reestruturação das atividades produtivas no Paraná. In: Cunha, M. S.; Shikida, P. F. A.; Rocha Jr. W. F. Agronegócio paranaense: Potencialidades e desafios. Cascavel: Edunioeste, 2002. p. 56-72.

[25] _ . A teoria da base econômica e o desenvolvimento regional do Estado do Paraná no final do século XX. 167f. Tese (Doutorado em Desenvolvimento Regional) - Universidade de Santa Cruz do Sul, Unisc, Santa Cruz do Sul, 2009.

[26] Sanchez, A. La Reinvención de Medellín. Documentos de Trabajo sobre Economía Regional y Urbana, Banco de la República. N. 174. 2012 disponible en: http://www.banrep.gov.co/es/node/29141. Consultado en 26 may 2018.

[27] Von Thünen, J. H. The isolated state. Oxford: Pergamom Press, 1966.

[28] Weber, A. Theory of the location of industries. Chicago: University of Chicago, 1969. 


\title{
Capítulo 6
}

\section{A migração venezuelana para o Brasil: Uma breve análise geográfica.}

\author{
Ygor Felipe Távora da Silva \\ Antonio Jorge Barbosa da Silva
}

Resumo: A Venezuela encontra-se numa dramática crise humanitária que afeta grande parte da população do país. A instabilidade política, o autoritarismo, a corrupção que assola o país, a recessão econômica, a falta de recursos básicos para a sobrevivência e a violência, bastam para que parte da população venezuelana decida por se deslocar para além das fronteiras daquele país. A crise também faz com que o país não seja mais um local pacífico para se viver, fazendo com que milhares de pessoas decidam por deixarem o país objetivando melhores condições de sobrevivência. No ano de 2016 a crise econômica, política e social que assolou a Venezuela acabou por atravessar as fronteiras do país, momento em que o fluxo migratório deste país para o Brasil aumentou consideravelmente. 0 estado brasileiro de Roraima se tornou o destino mais acessível àqueles que decidem por deixar a Venezuela, por possuir uma fronteira seca entre as cidades brasileira de Pacaraima e a venezuelana de Santa Elena. Com esse intenso fluxo migratório o Brasil acabou por ter seus serviços públicos sobrecarregados, pois, houve um grande e inesperado fluxo migratório de venezuelanos para o Brasil, e por conseguinte aumentouse a demanda de solicitações de refúgio no Estado brasileiro. Por estar o Brasil passando por uma crise econômica, vários municípios e Estados não receberam o montante financeiro necessário para manter os serviços básicos, o que não foi diferente com 0 Estado de Roraima. Frente a este pressuposto pretende-se responder ao seguinte questionamento: Qual o perfil do imigrante venezuelano residente no Brasil? 0 presente artigo possui como objetivo analisar o perfil dos venezuelanos que residem no norte do país, mais precisamente do Estado de Roraima, buscou-se conhecer a estrutura desta população, como vivem, características socioeconômicas, além das expectativas que estes possuem sobre o evento migratório. Entre os vários tipos de pesquisa existentes, optou-se para a realização deste trabalho a bibliográfica e documental, além de método de abordagem dedutivo, buscando em diferentes bancos de dados oficiais, informações que se fizessem necessárias para atender aos propósitos desse estudo, propiciando assim, uma análise detalhada a partir de referenciais geográficos, como mapas. Inicialmente, no presente estudo, verifica-se o contexto histórico e geográfico do Brasil e seus fluxos migratórios, a partir da perspectiva de "território-refúgio" para os imigrantes, em especial para os Venezuelanos. A posteriori, com os dados históricos obtidos é possível identificar detalhadamente os fenômenos sociais, políticos e econômicos do país materno, implicando no aumento quantitativo dos processos migratórios. Consequentemente, no Brasil, os serviços públicos, tais como Segurança Pública, Saúde, Educação, Subemprego, Favelização e Mobilidade. Por fim, percebe-se que é necessário realizar separadamente política publicas para os imigrantes indígenas e não-indígenas, em detrimentos às suas diferenças culturais, de necessidades e perspectivas a curto, médio e longo prazo. 


\section{INTRODUÇÃO}

A Venezuela vem enfrentando uma crise político-econômico-humanitária que está atingindo a maioria de sua população através de uma grande recessão, que levou a falta de recursos básicos e ao aumento da violência. Estas questões culminaram na migração de muitos venezuelanos para fora das fronteiras de seu país, buscando melhores condições de vida.

Desde o ano de 2016, esta crise da Venezuela atravessou suas fronteiras, com o aumento do fluxo migratório de sua população para outros países, especialmente para o Brasil. Roraima, estado brasileiro que faz fronteira direta com a Venezuela, através da cidade de Pacaraima, se tornou um destino muito acessível para os que decidem deixar seu país.

Com o aumento da demanda de solicitações de refúgio neste estado brasileiro, os serviços públicos em Roraima tem ficado sobrecarregados. Por estar o Brasil também enfrentando por uma crise econômica, Roraima, assim como outros estados do País, não tem recebido verbas financeiras suficientes para manter seus serviços básicos.

Em vista desta realidade, e procurando entender a situação em que se encontra Roraima perante esta situação, este artigo traz como questão norteadora o seguinte questionamento: Qual o perfil do imigrante venezuelano que está chegando ao Brasil e se estabelecendo em Roraima?

\section{OBJETIVOS}

O objetivo geral deste estudo foi analisar o perfil dos venezuelanos que estão se estabelecendo em Roraima, buscando entender esta população, como estão vivendo, quais suas características socioeconômicas e suas expectativas para o futuro.

Como objetivos específicos, o estudo buscou compreender o contexto histórico e geográfico do Brasil e seus fluxos migratórios, a partir da perspectiva de "território-refúgio" para os imigrantes, em especial para os Venezuelanos. Também procurou identificar os fenômenos sociais, políticos e econômicos do país materno, implicando no aumento quantitativo dos processos migratórios. Por fim, em relação ao Brasil, explicar como os serviços públicos, tais como Segurança Pública, Saúde, Educação e Mobilidade estão sendo aplicados à estes imigrantes.

\section{METODOLOGIA}

Este estudo foi desenvolvido através de uma revisão da literatura, com a busca de informações em artigos publicados em jornais e revistas científicas sobre o tema. que foram pesquisados nas bases de dados SciELO (Scientific Electronic Library Online), CAPES (Coordenação de Aperfeiçoamento de Pessoal de Nível Superior) do Ministério da Educação), além de publicações oficiais do governo.

\section{RESULTADOS PRELIMINARES}

\subsection{BRASIL COMO TERRITÓRIO-REFÚGIO DE IMIGRANTES}

Alguns países, como o Brasil, tem sido reconhecidos como locais de hospitalidade de refugiados, e estes lugares têm influenciado e sido influenciados pelas políticas de acolhimento a estas pessoas, afinal, o mundo hoje vive o maior e mais complexo fluxo migratório internacional desde a segunda guerra mundial. Em vista dessa enormidade de fluxos migratórios em todo o planeta, são vários os desafios se apresentam, o que possibilita uma ótima oportunidade para descobrir novas alternativas, por exemplo, para iniciativas privadas, práticas conduzidas pela sociedade civil organizada e para originar políticas públicas de acolhimento a estes deslocados (SPOLON; SOUZA, 2016).

As migrações internacionais para o Brasil já ocorrem a muitos anos, mas tem recebido maior destaque da imprensa nacional desde que ocorreu a migração em massa de haitianos e africanos, a partir de 2010. Agora, mais recentemente, outro fluxo de imigrantes ganhou destaque. Os venezuelanos, que podem ser classificados entre imigrantes econômicos, refugiados e asilados políticos, têm vindo para o Brasil em decorrência da crise político-econômica que está vivendo a Venezuela, buscando melhores condições de vida (RANINCHESKI; UEBEL, 2018). 
Segundo dados do Alto Comissariado das Nações Unidas para os Refugiados (United Nations High Commissioner for Refugees - UNHCR), o total de deslocados pelo mundo é de aproximadamente 69 milhões de pessoas, sendo que mais da metade (52\%) é menor de idade. Um dos países que mais tem recebido refugiados atualmente é o Brasil. No final de 2017, o País apresentava 85.700 pedidos de asilo, tendo recebido da Venezuela cerca de 17.900 pessoas (UNHCR, 2018).

A fronteira entre Brasil e Venezuela se materializa geograficamente entre os estados de Roraima (Brasil) e Bolivar (Venezuela), sendo que essa proximidade vai além do âmbito espacial, se materializando, também outros setores, com parcerias entre os países em áreas como educação, saúde, economia. Há, ainda, uma relação de necessidade e de cumplicidade entre ambos, pois o estado de Roraima depende da Venezuela para manter grande parte de sua rede de abastecimento de energia elétrica. As relações fronteiriças entre Brasil e Venezuela sempre foram complexas, pois trata-se de uma área de trânsito entre países que possuem diferentes idiomas, governos e sistemas econômicos, além de características culturais que se assemelham por um lado e se diferenciam por outro. Os países sempre mantiveram relações amigáveis, entretanto, com a crise econômica da Venezuela e a crise política no Brasil, esta relação tem estado mais delicada (MORAIS; SANTOS, 2017).

Procurando facilitar a legalização de imigrantes no Brasil, e abrindo mais espaço para a acolhida humanitária, foi criada a nova Lei de Migração, Lei no 13.445, de 24 de maio de 2017, que compreende a migração como um fenômeno da humanidade, simplificando vários procedimentos administrativos para o imigrante, como a criação do visto humanitário. Esse tipo de visto atende situações específicas, como dos apátridas e dos que chegam ao Brasil em razão de desastres ambientais, conflitos armados e violação dos direitos humanos (BRASIL, 2017).

\subsection{SITUAÇÃO ECONÔMICO-SOCIAL DA VENEZUELA E OS FENÔMENOS MIGRATÓRIOS}

A crise da Venezuela tem um forte fator político, polarizado ideologicamente com a crescente oposição, que associado com uma crescente onda de conservadorismo tem potencializado, em muitos aspectos, a crise econômica, originando, entre outros problemas, um déficit de insumos básicos (ARAGÃO; SANTI, 2018).

Após as eleições de dezembro de 2015, a Mesa de Unidade Democrática (MUD), coalizão de partidos políticos de oposição ao governo central venezuelano, assumiu o controle do Legislativo, o que intensificou ainda mais a divisão já latente entre os antigos apoiadores do ex-presidente Hugo Chávez, daqueles do atual presidente Nicolás Maduro. Desde então, a instabilidade política, econômica e social na Venezuela tem se deteriorado, o que vem se agravando ainda mais ao longo dos últimos meses, potencializando o fluxo de migrantes da Venezuela para o Brasil (MOREIRA, 2018).

Neste cenário, Ranincheski e Uebel (2018) fazem um alerta em relação as mensagens veiculadas pela mídia que, além de sensacionalismo, adulteram informações de forma a induzir os leitores a pensarem de determinada forma em relação a situação dos imigrantes. Segundo eles, é verificável o uso de abordagens pós-positivistas em reportagens brasileiras, e o quanto estas abordagens mascaram a realidade do fenômeno migratório, se posicionando e interferindo na explicação da realidade.

No mesmo sentido, os autores Morais e Santos (2017) revelam que a mídia brasileira tem levado seus leitores a "demonizarem" a migração dos venezuelanos, principalmente quando associa a imagem destas pessoas a atividades criminosas e taxas de desemprego, que, devido às necessidades de sobrevivência destes imigrantes, os levam a fazer qualquer tipo de trabalho, muitas vezes em condições exploratórias, que só beneficiam o empregador.

Mas, apesar destes problemas existirem, este fenômeno migratório que o Brasil vem vivenciando é muito mais complexo, conforme explicam Aragão e Santi (2018):

Trata-se de um contexto plural, no que diz respeito a uma multiplicidade de atores sociais, correspondentes à regiões e até mesmo etnias diversas dentro do território bolivariano. 0 Fluxo que Roraima vivencia não é somente o êxodo urbano-urbano, de Caracas, capital da Venezuela para Boa Vista, capital de Roraima. Mas, se trata de uma imigração que abrange diferentes regiões da Venezuela como de Tucupita, Estado Lara, 
Guayana, e regiões indígenas como o Delta Amaruco, entre outros (ARAGÃO; SANTI, 2018, p.139).

0 atual secretário da Organização das Nações Unidas (ONU), Antonio Guterres, realizou um discurso na $72^{\underline{a}}$ Assembleia Geral das Nações Unidas, onde fez uma declaração enfática, afirmando que muitos refugiados (em todo o mundo) têm sido estereotipados e utilizados para fins políticos. 0 secretário procurou conscientizar as pessoas que no mundo de hoje, onde sociedades tornam-se a cada dia mais multiculturais, multiétnicas e multirreligiosas, a diversidade que chega com a migração deve ser vista como uma riqueza, e não como uma ameaça (GUTERRES, 2017).

No intuito de mudar essa situação para os imigrantes venezuelanos, foi criado o projeto Somos Migrantes, na Universidade Federal de Roraima, em uma tentativa de interferir na dinâmica social, cultural, política e econômica referente a imigração venezuelana, através da produção de uma mídia alternativa. Seu objetivo é discutir possíveis melhorias e considerações que possam melhorar a informação sobre estas pessoas. Para isso, se mantém em constante diálogo com os imigrantes e refugiados, sejam eles indígenas ou não-indígenas, e também com instituições que trabalham com direitos humanos, tanto em nível nacional como internacional, objetivando melhorar a produção de conteúdo. Dessa forma, objetivam narrar esse acontecimento histórico de uma forma mais responsável e problematizadora (ARAGÃO; SANTI, 2018).

\subsection{A SITUAÇÃO DE RORAIMA E OS SERVIÇOS PÚBLICOS AOS IMIGRANTES}

Segundo dados da Organização Internacional para as Migrações (OIM), mais de dois milhões de venezuelanos, nos últimos anos, decidiram fugir de seu país em decorrência da crise política e econômica, principalmente devido à falta de alimentos e remédios. Em Roraima é por onde a maioria destes imigrantes chega ao Brasil, portanto as dificuldades locais são evidentes. Roraima possui pouco mais de 300 mil habitantes, com limitadas oportunidades de trabalho, o que acaba dificultando uma plena integração destas pessoas (DRAGHI, 2018).

Com a entrada de imigrantes, o perfil da cidade de Boa Vista, principal destino destas pessoas, sofreu mudanças, tanto estéticas quanto sociais, significativas. Estas mudanças começaram a ser notáveis no final de 2015, com a ocupação dos espaços urbanos da cidade por uma quantidade considerável de imigrantes, que se localizavam nas principais praças da cidade, que dispõe de acesso livre à internet, e exercendo atividades informais em sinais, bares e comércios (ARAGÃO; SANTI, 2018).

A partir do segundo semestre de 2016 isso se agravou, havendo uma ocupação das ruas como morada, pois a situação econômica destas pessoas é tão precária que ficam impossibilitados de pagar um aluguel. Com isso, muitas famílias acabam como moradores de rua. Essa situação ocorreu principalmente no contexto da imigração indígena-venezuelana, em especial por indígenas da etnia Warao, proveniente da região do Delta do Orinoco, que é composta pelos estados venezuelanos do Delta Amacuro, Monagás e Sucre (ARAGÃO; SANTI, 2018; MOREIRA, 2018).

De acordo com a Organização Internacional para as Migrações (OIM, 2018), os indígenas migrantes possuem todos os mesmos direitos que são assegurados pelas leis internacionais e brasileiras aos indígenas nacionais, como o acesso ao subsistema de saúde indígena, o direito à documentação, à nacionalidade, à moradia e à autodeterminação, bem como o direito de transitar por fronteiras e de estar na cidade e ter acesso às políticas sociais destinadas aos povos indígenas.

Apesar disso, em pesquisa realizada pelo Observatório das Migrações Internacionais (OBMigra), 48,4\% dos venezuelanos em Boa Vista, até outubro de 2017, não utilizam qualquer serviço público. Ainda assim, o fator de maior preocupação em Roraima é o surgimento de conflitos sociais pela disputa de emprego, vagas no sistema público de ensino e em hospitais (FGV, 2018).

A cidade de Boa Vista apresenta um cenário onde uma parcela da população local já era carente de políticas integradas de educação, inserção digna no mercado de trabalho, e de ampliação dos serviços de saúde. Com a chegada dos imigrantes, e como a prefeitura não tem recebido apoio dos governos estadual e federal para atrair projetos de desenvolvimento econômico para a região, ela não consegue prover o necessário a uma população que agora se tornou majoritariamente desempregada, ou inserida no mercado informal, e pouco instruída (FGV, 2018).

Entre as principais medidas que vem sendo tomadas com o objetivo de solucionar os efeitos desta imigração no Brasil está a criação de abrigos em cidades de recepção de imigrantes indígenas e não 
indígenas. Porém, este auxílio tem sido prestado com o auxílio de organizações internacionais especializadas, como a ONU e a Organização Internacional de Migração (OIM), que inclusive abriu um escritório regional em Boa Vista para cuidar da situação. Estas organizações internacionais têm tido um papel fundamental, não apenas na assistência humanitária, como também na mediação da própria crise internacional na Venezuela, juntamente aos governos vizinhos (MOREIRA, 2018).

Também tem sido realizadas missões de apoio ao município local com distribuição de remédios, alimentos, bens de primeira necessidade, através do Conselho Nacional de Imigração (CNIg), em conjunto com outras instituições de governo e organizações não governamentais, como o Alto Comissariado das Nações Unidas para os Refugiados (UNHCR) (FGV, 2018).

A prefeitura de Boa Vista fez um levantamento e identificou 25 mil venezuelanos, correspondendo a $7 \%$ do total de habitantes da cidade. Tem sido priorizada a primeira acolhida a estes imigrantes, objetivando atender esta população com alimentos, atendimento médico e abrigo. A integração tem ficado para uma segunda etapa, tendo em vista que faltam vagas para crianças nas escolas e também emprego para estas pessoas, já que o mercado de trabalho em todos o Estado está sendo incapaz de absorver esta quantidade de migrantes. Este fato tem ocasionado situações de exploração do trabalho, com os venezuelanos menos qualificados competindo diretamente com os brasileiros, o que gera preconceito e xenofobia (DRAGHI, 2018).

Inclusive, já se tornaram frequentes os episódios de violência contra mulheres e adolescentes venezuelanas em Boa Vista, que passaram a ser vítimas de estupros e espancamentos em função de sua nacionalidade (MOREIRA, 2018). No mês de fevereiro de 2018, aconteceram dois ataques a venezuelanos: uma bomba lançada na casa de uma família venezuelana e um incêndio criminoso em uma casa onde viviam 31 venezuelanos (FGV, 2018).

\subsection{PERFIL DO IMIGRANTE VENEZUELANO}

A maioria dos imigrantes não-indígenas que chega ao Brasil o faz por meios terrestres, de forma legal, a maioria em ônibus. Já os indígenas, do povo Warao, chega ao Brasil a pé, atravessando a fronteira até a cidade brasileira de Pacaraima, em Roraima. Da fronteira, ou continuam a caminhar ou utilizam o transporte rodoviário até a cidade de Boa Vista, capital de Roraima, ou ainda até a cidade de Manaus, no Amazonas, que também tem se tornado importante ponto de atração de venezuelanos, principalmente indígenas, fato que levou à criação de abrigos nessas localidades (MOREIRA, 2018).

De acordo com dados do estudo do OBMigra, o perfil do migrante venezuelano que se encontra inserido no mercado de trabalho no Brasil é o de indivíduos que trabalham no setor de serviços e de atendimento ao público. A situação destes imigrantes no Brasil tem apresentado um perfil diferenciado, pois a maioria deles permanece concentrada na fronteira do País, em Pacaraima, cidade fronteiriça por onde a maioria entra no País, ou na Capital do Estado, em Boa Vista, para onde a maioria segue logo após adentrar ao Brasil. De acordo com o estudo, a principal diferença entre os venezuelanos e os haitianos, é que estes últimos imigraram depois de um terremoto em seu país de origem, enquanto os venezuelanos estão chegando por questões políticas e econômicas. Por este motivo, boa parte deles ainda resistem à interiorização do País, e permanecem em Roraima, pois têm a esperança de que a situação melhore na Venezuela e eles possam voltar (CARVALHO; SILVA; SENHORAS, 2018).

A inserção destes imigrantes no setor terciário é natural, por ser este o setor com maior demanda de mão de obra em qualquer economia, sendo concentrador da mão de obra que, quando qualificada, obtém espaço em supermercados, restaurantes e outros serviços de atendimento ao público. Porém, quando pouco qualificada ou com baixa escolaridade, acaba se concentrando no trabalho braçal, como domésticas ou ajudantes na construção civil (CARVALHO; SILVA; SENHORAS, 2018).

Segundo a Fundação Getúlio Vargas (FGV, 2018) dados do OBMigra indicam que 60\% desses imigrantes, em 2017, se encontravam empregados em alguma atividade remunerada e enviavam dinheiro para suas famílias na Venezuela. Ou seja, apesar de subvalorizada profissionalmente, é uma imigração que traz benefícios para o Brasil.

Além disso, como já dito, também estão fugindo das condições econômicas desfavoráveis de seu país integrantes de povos indígenas da etnia Warao (MORAIS; SANTOS, 2017). Estes, em sua 
maioria, acabaram se transformando em moradores de rua, passando a exercer a "mendicância" em busca de algum retorno financeiro no espaço urbano. Esta situação originou um grande impacto negativo na sociedade local, o que levou ao surgimento de preconceitos e atos xenofóbicos. Por outro lado, também levou a cobrança de atitude dos governos Estadual e Municipal, para solucionar essa situação que se instalou na cidade (ARAGÃO; SANTI, 2018).

A inserção destes imigrantes ilegais no mercado de trabalho em Roraima tem ocorrido de forma marginal e em condições que causam preocupação, pois surgem as atividades legais, como pedintes e flanelinhas, ou domésticas contratadas por dia com pagamento de subsalários. Um agravante são as atividades ilegais ligadas a redes de prostituição ou grupos/facções de atividades criminais. E observa-se que a maioria dos imigrantes ilegais (maioria indígenas) que tem chegado a Roraima apresenta baixa qualificação, enquanto os que chegam de forma legal, ao contrário, são altamente qualificados e com alta escolaridade (CARVALHO; SILVA; SENHORAS, 2018).

De acordo com Aragão e Santi (2018), o perfil do imigrante venezuelano não-indígena é composto por $72 \%$ de jovens entre 20 a 39 anos, com um bom nível de escolaridade onde $78 \%$ apresentam nível médio completo, e 32\% com nível superior completo ou pós-graduação.

Entre os não-indígenas de maior escolaridade, muitos têm demonstrado interesse em se deslocar para outros Estados Brasileiros, enquanto os de menor escolaridade acabam preferindo permanecer em Boa Vista, por já terem se adaptado ou pela proximidade com a fronteira, na esperança de poderem voltar à Venezuela, quando a situação melhorar (MOREIRA, 2018).

\section{CONSIDERAÇÕES FINAIS}

Através deste estudo foi possível perceber que a mídia tem veiculado informações incompletas, que não correspondem à realidade de todos os imigrantes venezuelanos no Brasil, estigmatizando essa população.

Existem dois perfis de imigrantes: os indígenas, que são os que mais necessitam de apoio de serviços e políticas públicas; e os não-indígenas, que apresentam desde pessoas com menor qualificação até outros com alta qualificação profissional. Esta população com menor qualificação vem sendo explorada por empregadores inescrupulosos, com pagamento de subsalários, aos quais estas pessoas se submetem, para não passarem necessidade ainda maior.

Por enquanto, ainda não se elucida qual será a capacidade de resposta do Governo Brasileiro em relação a esta população imigrante, que já enfrenta e causa uma série de desafios. Muitos têm esperança de poder voltar à Venezuela, acreditando que as coisas podem melhorar por lá, enquanto outros vêm buscando uma forma de se integrar e se estabelecer no Brasil.

Por fim, percebe-se que é necessário realizar separadamente políticas públicas para os imigrantes indígenas e para os não-indígenas, em razão de suas diferenças não apenas culturais, mas principalmente de necessidades e perspectivas de futuro.

\section{BIBLIOGRAFIA}

[1] Aragão, T.; Santi, V. Somos migrantes: o uso das redes sociais na produção midiática alternativa sobre a migração venezuelana em Roraima. Aturá Revista Pan-Amazônica de Comunicação, v.2, n.1, p.136-156, 2018.

[2] Brasil. Presidência da República. Casa Civil. Subchefia para Assuntos Jurídicos. Lei no 13.445, de 24 de maio de 2017. Institui a Lei de Migração. Brasília: Casa Civil, 2017.

[3] Carvalho, P.R.S.; Silva, L.C.; Senhoras, E.M. Serviços e atendimentos são os setores que mais empregam venezuelanos. Jornal Folha de Boa Vista, 19 de julho, 2018. Disponível em: < https://bit.ly/2uXXUX2>. Acesso em: 21 jul. 2018.

[4] Draghi, D. 0 mercado de trabalho informal em Roraima e as dificuldades vividas pelos venezuelanos. MigraMundo. Publicado em: 18 jul. 2018. Disponível em: <https://bit.ly/2mrSFer>. Acesso em: 21 jul. 2018.

[5] FGV - Fundação Getúlio Vargas. Desafio migratório em Roraima. Repensando a política e a gestão da migração no Brasil. Rio de Janeiro: FGV, 2018.

[6] Guterres, A. Statement presented at the 72nd Session of the General Assembly of the United Nations. New York: General Assembly of the United Nations, 2017. Disponível em: <https://bit.ly/2LrNpWj>. Acesso em: 19 jul. 2018. 
[7] Morais, V.M.I.; Santos, L.C.C. Mediações e cibercultura: estudo de comentários em matéria jornalística sobre a imigração venezuelana em Roraima. Aturá Revista Pan-Amazônica de Comunicação, v.1, n.2, p.120$144,2017$.

[8] Moreira, P.G. Entorno e primeiras respostas (g) locais à instabilidade na Venezuela. Boletim Regional, Urbano e Ambiental, n.18, 87-95, 2018.

[9] Oim - Organização Internacional para as Migrações. Aspectos jurídicos da atenção aos indígenas migrantes da Venezuela para o Brasil. Brasília: Organização Internacional para as Migrações, Agência das Nações Unidas para as Migrações, 2018.

[10] Ranincheski, S.; Uebel, R.R.G. "Polícia Federal deporta 450 imigrantes ilegais venezuelanos de Roraima": um estudo sobre remediation, positivismo e pós-positivismo no jornal 0 Globo. Diálogo, n.37, p.3952,2018

[11] Spolon, A.P.G.; Souza, M.S.M. Hospitalidade, mobilidade humana e cidades: a experiência de São Paulo no acolhimento a imigrantes e refugiados. Anais do Seminário da ANPTUR, 2016.

[12] Unhcr - United Nations High Commissioner for Refugees. Global Trends - Forced Displacement in 2017. Unhcr, 2018. 


\section{Capítulo 7}

Reflexões sobre os objetivos de desenvolvimento sustentável sob a ótica do empoderamento feminino indígena no médio e submédio São Francisco - BA

\section{Gisele das Chagas Costa}

\section{Regina Celeste de Almeida Souza}

Resumo: 0 artigo tem como objetivo refletir sobre a questão de gênero presente na Agenda 2030 através da experiência de mulheres indígenas residentes em comunidades dos referidos trechos do Rio São Francisco. A contribuição da pesquisa bibliográfica e documental favoreceu o entendimento da expressividade da questão de gênero, contida nos Objetivos de Desenvolvimento Sustentável (ODS), também conhecida como Agenda 2030. Dados da pesquisa de doutorado concluída subsidiaram a discussão sobre os processos de empoderamento feminino engendrados na área de estudo. Os resultados apontam uma densificação da rede de lideranças femininas indígenas na área delimitada na pesquisa, congregando forças para auxiliar seu povo na luta pelos direitos socioterritoriais historicamente negados pelo Estado brasileiro. Conclui-se que, entre os povos pesquisados, não é possível prosseguir com suas pautas reivindicatórias e ultrapassar os silenciamentos e invisibilidades aos quais foram subjugados durante séculos sem a efetiva participação da mulher. 


\section{INTRODUÇÃo}

O presente artigo reflete sobre o Objetivo 5 da Agenda 2030 - alcançar a igualdade de gênero e empoderar todas as mulheres e meninas - e o paradigma do desenvolvimento sustentável considerando a experiência de empoderamento de mulheres indígenas no médio e submédio São Francisco, onde foi realizada uma pesquisa no período 2012 - 2016.

Tendo como objetivo refletir sobre a questão de gênero presente na Agenda 2030 através da experiência de mulheres indígenas residentes em comunidades do médio e submédio São Francisco, buscou um percurso metodológico balizado na pesquisa documental e bibliográfica. Os dados consolidados da pesquisa concluída completaram a proposta de elaboração textual.

A primeira seção aborda o contexto da Agenda 2030, situando as questões de gênero e empoderamento feminino em uma perspectiva contemporânea, apresentando alguns dos inúmeros desafios para a efetivação da equidade de gênero.

Em seguida, buscou-se evidenciar o discurso, presente na referida Agenda e documentos correlatos, da indissociabilidade existente entre o efetivo desenvolvimento sustentável e a superação das questões históricas que impedem o pleno desenvolvimento de mulheres e meninas.

Após o panorama apresentado nas seções anteriores o texto trata da geo-história dos povos indígenas no Vale Sanfranciscano, criando o embasamento para compreensão do empoderamento feminino no médio e submédio São Francisco, BA, onde foi realizada a pesquisa.

Na seção que antecede as considerações finais, foi possível trazer à discussão a trajetória de empoderamento de mulheres pertencentes a vários povos indígenas na área de estudo, em um claro exemplo de novos papeis experenciados pelas mulheres indígenas, congregando forças para auxiliar seu povo na luta pelos direitos socioterritoriais.

0 artigo concluiu que, entre os povos pesquisados não é possível prosseguir com suas pautas reivindicatórias e ultrapassar os silenciamentos e invisibilidades aos quais foram subjugados durante séculos sem a efetiva participação da mulher.

\section{OS OBJETIVOS DE DESENVOLVIMENTO SUSTENTÁVEL}

A discussão sobre o desenvolvimento sustentável tomou maior impulso a partir de 2015 quando a Organização das Nações Unidas (ONU) através de seus 193 países membros assinou a chamada Agenda 2030, composta por 17 objetivos de desenvolvimento sustentável (ODS) e 169 metas correlatas.

Essa agenda dá continuidade aos Objetivos do Milênio (ODM) que foram estabelecidos também pelos países membros das Nações Unidas para sua consecução durante o período 2000 - 2015.

Os ODM efetivaram uma "nova parceria global para reduzir a pobreza extrema" (ONU, 2010) através de oito objetivos, quais sejam: 1 . acabar com a fome e a miséria; 2 . educação básica de qualidade para todos; 3. igualdade entre sexos e valorização da mulher; 4 . reduzir a mortalidade infantil; 5. melhorar a saúde das gestantes; 6 . combater a aids, a malária e outras doenças; 7 . qualidade de vida e respeito ao meio ambiente; 8 . todo mundo trabalhando pelo desenvolvimento.

Para ONU (2017), os objetivos factualmente auxiliaram na diminuição da pobreza global; no aumento da frequência de crianças na escola primária; na diminuição significativa na taxa de mortalidade infantil; na expansão do acesso à água potável; e em investimentos significativos no combate à malária, aids e tuberculose.

Destes, vale destacar que o Objetivo 3 - igualdade entre sexos e valorização da mulher, foi alcançado parcialmente, no mundo e no Brasil, com melhoria no acesso à educação em todos os níveis de ensino.

Ao desdobrar este objetivo no item trabalho e renda, através de uma análise regional, observa-se que a Bahia apresenta uma participação feminina de 43,7\% no mercado de trabalho formal, segundo dados de 2015 (PORTAL ODM, s/d).

Ainda considerando o ano de 2015 no Estado da Bahia, o rendimento real médio das mulheres equivale a $92,3 \%$ do rendimento masculino, com a desigualdade salarial aumentando 
drasticamente para o ensino superior: 65,2\% (op cit., s/d).

No item participação política, o Objetivo 3 demonstra o tamanho da desigualdade de gênero, considerando dados da Bahia em 2016: "apenas 32,4\% dos candidatos para a Câmara

de Vereadores, em 2.016, eram mulheres. A proporção de mulheres eleitas para a Câmara de

Vereadores no Estado foi de 12,2\%." (PORTAL ODM, s/d).

Mesmo com alguns avanços, é preciso ressaltar que a "desigualdade das mulheres em relação aos homens ainda persiste no mercado de trabalho, nos rendimentos e na política. E a violência doméstica continua atingindo milhares de mulheres brasileiras. (BRASIL, s/d, grifos do autor)

Diante do quadro de avanços e inúmeros desafios a serem enfrentados, não apenas na questão de gênero, é que, em 2015, a ONU e seus países membros “[...] tiveram a oportunidade de adotar a nova agenda de desenvolvimento sustentável [...]" (ONU, s/d). Assim, os 17 ODS se baseiam nos 08 ODM e, na visão da ONU, determinarão, nos próximos 15 anos, "o curso global de ação para acabar com a pobreza, promover a prosperidade e o bem- estar para todos, proteger o meio ambiente e enfrentar as mudanças climáticas". (ONU, op cit., grifos do autor).

Os 17 ODS estão assim enunciados: 1. acabar com a pobreza em todas as suas formas, em todos os lugares; 2 . acabar com a fome, alcançar a segurança alimentar e melhoria da nutrição e promover a agricultura sustentável; 3. assegurar uma vida saudável e promover o bem-estar para todos, em todas as idades; 4. assegurar a educação inclusiva e equitativa de qualidade, e promover oportunidades de aprendizagem ao longo da vida para todos; 5. alcançar a igualdade de gênero e empoderar todas as mulheres e meninas; 6. assegurar a disponibilidade e gestão sustentável da água e o saneamento para todos; 7. assegurar a todos o acesso confiável, sustentável, moderno e a preço acessível à energia; 8. promover o crescimento econômico sustentado, inclusivo e sustentável, emprego pleno e produtivo e trabalho decente para todos; 9. construir infraestruturas resilientes, promover a industrialização inclusiva e sustentável e fomentar a inovação; 10. reduzir a desigualdade dentro dos países e entre eles; 11. tornar as cidades e os assentamentos humanos inclusivos, seguros, resilientes e sustentáveis; 12 . assegurar padrões de produção e de consumo sustentáveis; 13. tomar medidas urgentes para combater a mudança do clima e os seus impactos; 14 . conservar e usar sustentavelmente os oceanos, os mares e os recursos marinhos para o desenvolvimento sustentável; 15. proteger, recuperar e promover o uso sustentável dos ecossistemas terrestres, gerir de forma sustentável as florestas, combater a desertificação, deter e reverter a degradação da terra e deter a perda de biodiversidade; 16. promover sociedades pacíficas e inclusivas para o desenvolvimento sustentável, proporcionar o acesso à justiça para todos e construir instituições eficazes, responsáveis e inclusivas em todos os níveis; e 17. fortalecer os meios de implementação e revitalizar a parceria global para o desenvolvimento sustentável.

O ODS 5 - alcançar a igualdade de gênero e empoderar todas as mulheres e meninas, dá continuidade ao ODM 3, e tem 6 metas correlatas, a saber:

5.1 acabar com todas as formas de discriminação contra todas as mulheres e meninas [...]; 5.2 eliminar todas as formas de violência contra todas as mulheres e meninas nas esferas públicas e privadas, incluindo o tráfico e exploração sexual e de outros tipos; 5.3 eliminar todas as práticas nocivas,

como os casamentos prematuros, forçados e de crianças e mutilações genitais femininas; 5.4 reconhecer e valorizar o trabalho de assistência e doméstico não remunerado, por meio da disponibilização de serviços públicos, infraestrutura e políticas de proteção social, [...] conforme os contextos nacionais; 5.5 garantir a participação plena e efetiva das mulheres e a igualdade de oportunidades para a liderança em todos os níveis de tomada de decisão na vida política, econômica e pública; 5.6 assegurar o acesso universal à saúde sexual e reprodutiva e os direitos reprodutivos [...]. (BRASIL; ONU, 2016)

A busca pela paridade de gênero é secular. A primeira onda do feminismo teve início no final do século XIX e se estendeu pelas três primeiras décadas do século XX. E, se nesse primeiro momento histórico a principal característica é a luta pelos direitos políticos, incluindo o direito ao 
voto - no Brasil somente em 1932 o sufrágio feminino foi garantido - atualmente a discussão alcançou uma abrangência donde se infere não ser possível o desenvolvimento sustentável sem a igualdade entre homens e mulheres.

As mulheres historicamente vêm contribuindo de maneira significativa para o progresso da humanidade. Sua presença se dá em todos os setores de atividades produtivas, porém nos quesitos respeito e reconhecimento ainda existe um déficit social.

Como sintetiza ONU Mulheres (s/d):

\begin{abstract}
"As mulheres já percorreram um longo caminho até aqui. Estudar, trabalhar, votar, candidatar-se a cargos políticos e ocupar postos de liderança, por exemplo, são direitos conquistados muito recentemente pelas mulheres brasileiras. Mas a marca do estigma e da desigualdade ainda está muito presente na sociedade e é um freio para o desenvolvimento sustentável do país."
\end{abstract}

Faz-se necessário a inclusão sistemática da questão de gênero na implementação da Agenda 2030, uma vez que se torna inviável o efetivo desenvolvimento sustentável e o alcance do potencial humano se ainda persiste para metade dos seres humanos a negação do exercício pleno dos direitos humanos.

A ONU Mulheres lançou, em 2015 uma iniciativa de apoio à Agenda 2030 intitulada "Por um planeta 50-50 em 2030: um passo decisivo pela igualdade de gênero", onde são propostas ações em torno do fortalecimento dos direitos conquistados pelas mulheres, além da criação de programas com vistas à erradicação da violência contra mulher, programas de incentivo à participação das mulheres nas esferas decisórias, entre outras (ONU Mulheres, s/d)

Nesse contexto onde a discussão do efetivo desenvolvimento sustentável não se dissocia do empoderamento feminino e igualdade de gênero, há de se ressaltar que as lutas, avanços, retrocessos e desafios enfrentados pelas mulheres devem ser singularizados ao se

lançar uma perspectiva analítica sobre povos e comunidades tradicionais, entre elas, os povos indígenas.

Questões de gênero existem em qualquer grupo social, no entanto, ao lançar luzes sobre essa questão entre os povos indígenas se faz necessário o devido enquadramento a partir de seu percurso sócio-histórico e territorial.

Os caminhos percorridos pelos povos indígenas são marcados pela resistência ao genocídio e às políticas institucionais de assimilação cultural. Buscando um recorte espacial no nordeste indígena $^{6}$, pode-se também afirmar que tais povos, resilientes, vêm construindo suas territorialidades em uma perspectiva múltipla, diversa e complexa, reafirmando sua identidade como um dos mecanismos para ultrapassar o violento processo de invisibilidade imposto historicamente pelo Estado brasileiro.

Portanto, ao tratar as questões de gênero entre esses povos, observa-se que, até certo ponto, tais questões encontram-se imbricadas com as pautas gerais de luta do próprio movimento indígena nordestino e brasileiro.

A ONU Mulheres através da cooperação com a Embaixada da Noruega vem buscando fortalecer a "atuação de mulheres indígenas em espaços de decisão dentro e fora de suas comunidades" (ONU Mulheres, s/d) através do projeto Voz das Mulheres Indígenas, o qual agrega inúmeras etnias indígenas brasileiras.

“Ao apoiar a construção de espaços internos de tomada de decisão constituídos exclusivamente por mulheres indígenas, o projeto permitiu que [...] um grupo de mulheres líderes coletassem informações em comunidades indígenas por todo o Brasil e constituíssem, pela primeira

6 Tal recorte espacial se justifica pela familiaridade das autoras com a temática na área geográfica em questão. Desde 2012, através do Projeto Rio São Francisco: cultura, identidade e desenvolvimento, vem sendo realizada uma investigação sistemática em torno do empoderamento feminino no Nordeste indígena, mais especificamente nos trechos médio e submédio São Francisco, BA, onde se observa a densificação da presença de lideranças femininas indígenas, incluindo aí a presença de 14 caciques (dados de 2016). A pesquisa em questão gerou várias publicações, incluindo uma tese de doutorado, cujos dados são parcialmente apresentados e discutidos no presente artigo. 
vez, uma pauta nacional comum das mulheres indígenas brasileiras." (ONU Mulheres, s/d)

Tal pauta articula-se em torno de cinco eixos temáticos, a saber: 1. violação dos direitos das mulheres indígenas (incluindo a violência contra mulheres e meninas); 2. empoderamento político; 3 . direito à terra e processos de retomada; 4. direito à saúde, educação e segurança; e 5. tradições e diálogos intergeracionais.

Excetuando-se os dois primeiros eixos, os demais dialogam com pautas historicamente defendidas pelo movimento indígena brasileiro e, em relação ao eixo 3 que trata das questões territoriais indígenas, ressalta-se que o mesmo se constitui como premissa pra a efetivação do desenvolvimento sustentável, que será discutido na próxima seção.

\section{DESENVOLVIMENTO SUSTENTÁVEL}

As questões relacionadas a crise ambiental têm sua origem associada ao advento do modo de produção industrial que, desde a primeira revolução industrial no final do século XVIII até o presente, inobservou o uso racional e sustentável dos recursos ambientais e energéticos, gerando um passivo ambiental.

Passivo este que se intensificou a cada nova fase industrial, dado que em cada uma observa-se a inserção de conteúdos técnicos, científicos e informacionais, com possibilidades quase que ilimitadas de manipulação e transformação da natureza.

Na segunda metade do século XX, com o advento da terceira revolução industrial que se caracteriza, entre outros aspectos, pela inserção de novas tecnologias no processo produtivo, tais como a informática e a robótica e consequente aumento da produtividade, emerge uma preocupação, em nível mundial, dos efeitos negativos advindos de um modelo de produção secularmente alicerçado na visão do ambiente enquanto fornecer ilimitado de recursos para as sociedades humanas.

A contemporaneidade vivencia mudanças paradigmáticas em curso, incluindo aquelas voltadas para a relação ser humano - sociedade - meio ambiente, o que têm possibilitado a criação de um lastro para transformações significativas em tal relação.

Nessa perspectiva, o conceito de desenvolvimento sustentável vem ganhando cada vez mais espaço no planejamento territorial e em práticas ecologicamente sustentáveis, nas mais diversas esferas da vida social.

O desenvolvimento sustentável parte da premissa da utilização dos recursos ambientais com vistas à manutenção do capital natural e utilização econômica considerando a capacidade de manutenção do sistema.

Tal conceito consolidou-se no relatório elaborado pela Comissão Mundial sobre o Meio Ambiente e Desenvolvimento das Nações Unidas e denominado "Nosso Futuro Comum" (também conhecido como Relatório Brundtland, em referência à então primeira-ministra da Noruega, Gro Harlem Brundtland, que presidiu os trabalhos).

O mesmo foi formalizado em 1987 pela Comissão Mundial de Meio Ambiente e Desenvolvimento (CMMAD), sendo definido como aquele que satisfaz as necessidades do presente sem comprometer a capacidade das gerações futuras satisfazerem as suas próprias necessidades.

Cumpre esclarecer que o paradigma do desenvolvimento sustentável, o qual vem norteando os principais documentos e propostas definidoras de um novo modelo de ação e interação das sociedades com o ambiente natural, passou por diversas elaborações, desde a "abordagem do ecodesenvolvimento" na Conferência de Estocolmo de 1972 (DIAS, 2011) até o atual conceito.

Sachs (2002), ao discutir o conceito de desenvolvimento sustentável, afirma que o mesmo só pode ser efetivamente utilizado quando se consideram, de modo indissociável, o crescimento socioeconômico e a conservação ambiental.

Para esse autor, o desenvolvimento é incompatível "com o jogo sem restrições das forças do mercado" (SACHS, 2002, p. 55), o qual se encontra alicerçado em um paradigma científico que prima pela dominação da natureza através do progresso técnico das sociedades. 
E, para que o mesmo ocorra, é necessário não apenas o comprometimento com as gerações futuras, mas, sobretudo, com a sociedade e toda forma de vida no planeta, por meio da ecologização do pensamento e do desenvolvimento da consciência ambiental, dado que:

“À ética imperativa da solidariedade sincrônica com a geração atual somou- se a solidariedade diacrônica com as gerações futuras e, para alguns, o postulado ético de responsabilidade para com o futuro de todas as espécies vivas na Terra. [...] o contrato social no qual se baseia a governabilidade de nossa sociedade deve ser complementado por um contrato natural." (SACHS, op cit., p. 49)

A noção de desenvolvimento sustentável (crescimento econômico, social e conservação ambiental) requer, necessariamente, uma abordagem sistêmica no desenvolvimento da investigação científica. Tal abordagem favorece à análise da inter-relação entre a ação antrópica e as alterações no ambiente, propiciando uma visão de síntese.

De fato, a natureza não pode ser separada do mundo do trabalho, pois, em termos de fluxo de matéria e energia no planeta, simplesmente não existe o termo externo e a economia humana, em última análise, é um subsistema da ecosfera. Deste ponto de vista, faz-se necessário que a noção de sustentabilidade vá além da gestão dos recursos naturais para a gestão da própria humanidade no sistema Terra.

\section{GEOHISTÓRIA DOS POVOS INDÍGENAS NO VALE SANFRANCISCANO}

Nesta seção, cabe iniciar a discussão traçando um quadro geohistórico dos povos indígenas no Vale Sanfranciscano, ainda que resumido, para situar e embasar a discussão do empoderamento feminino indígena, cujo recorte espacial converge para o médio e submédio São Francisco, BA.

O Vale Sanfranciscano vem vivenciando, a partir da segunda metade do século XX, profundas transformações estruturais no modo de produção do espaço regional.

Tais reordenamentos territoriais, impulsionados pela implementação de políticas energéticas no Vale, vem densificando, desde então, o espaço com objetos técnicos voltados sobretudo para uma agricultura irrigada direcionada a exportação.

O território é reduzido, assim, a uma perspectiva unidimensional, ao valor de troca e seu domínio especulativo.

Souza e Ramos (1998) traçam o eixo histórico da construção de tais empreendimentos. Considerando as intervenções territoriais no Estado da Bahia, as autoras sinalizam:

"O complexo de Paulo Afonso, com as diversas barragens que aí foram instaladas, a partir dos anos 1950, para a geração de eletricidade, veio a ser bastante significativo para o crescimento da Região Nordeste. A de Sobradinho, construída nos anos 1970 e inaugurada em 1978 [...] causou um impacto socioeconômico e ambiental sem precedentes [com] a inundação de quatro cidades - Casa Nova, Pilão Arcado, Remanso e Sento Sé - e muitas vilas [...]."

Sobre essa questão, o Conselho Indigenista Missionário aponta que "as hidrelétricas existentes foram responsáveis pela remoção forçada de mais de 150 mil pessoas, entre as quais vários povos indígenas, compulsoriamente deslocados [...]" (TOMÁZ et al, 2008, p. 12), reassentados em agrovilas, ou outros espaços, muitas vezes distantes, com terras menos férteis e sem as marcas de uma cultura material e simbólica que impregnavam seus territórios tradicionais.

Os impactos negativos das políticas energéticas sobre os povos indígenas do Vale Sanfranciscano intensificaram e complexificaram uma situação de vulnerabilidade socioterritorial, a que estão sujeitos ao longo dos séculos de formação e consolidação do território brasileiro.

Vale ressaltar que o Rio São Francisco foi o principal vetor de colonização no sertão baiano, garantindo "a expansão de frentes pioneiras de criação de gado, que tinham no território que margeia o grande rio uma pastagem natural apropriada para o criatório extensivo." (NASCIMENTO, 1995, p. 67). 
Assim, os territórios tradicionais de inúmeros povos são vistos como empecilhos para o projeto colonizatório. No entanto, a relação dos povos indígenas com o Rio São Francisco antecede e muito, a tomada de seus territórios pelos europeus, sendo, ao longo de 9.000 anos de ocupação humana (MARTIN, 1998; SANTOS, 2008), abundante fonte alimentar e também base de sustentação espiritual, através de suas práticas ritualísticas envolvendo o rio, ou seja, um importante marco de seu patrimônio cultural material e imaterial.

Não cabe explicitar no curto espaço que cabe nessa seção, as atrocidades, os requintes de crueldade que marcaram o genocídio dos povos indígenas do Vale ao longo dos séculos.

Porém, ainda que de maneira demasiadamente resumida, destacam-se, entre as políticas de extermínio físico (e posteriormente sociocultural), o agrupamento compulsório de vários povos nas missões, que povoaram o Vale entre os séculos XVII e XVIII, buscando o amansamento dos bravios, a conversão e a formação de mão-de-obra, ainda escassa nos primeiros séculos de colonização.

Com o fim das missões em meados do século XVIII, criam-se as vilas, e numa clara política de mistura étnica, a administração pombalina incentiva e orienta a ocupação não- indígena, objetivando a assimilação cultural.

Essas e outras políticas de esfacelamento cultural e socioterritorial fornecem a base de sustentação de um discurso oficial e também acadêmico, vigente até o início do século XX, de que não existiam mais indígenas no Nordeste, não sendo necessário e justificável, portanto, políticas de demarcação territorial de povos indígenas, já estando todos miscigenados.

O final do século XIX e início do século XX assiste um interessante processo de resistência dos povos indígenas do Vale, com articulações, retomadas territoriais, aprendizagens, empréstimos culturais e etnogêneses.

A partir do século XX se estabelece, portanto, uma rede de emergências étnicas (ARRUTI 1995, 2006). Vale retomar o ponto, de que a grande dificuldade dos povos indígenas nordestinos serem reconhecidos como tais, ocorre em função da grande miscigenação. As políticas do início do século XX traziam o entendimento do indígena dentro de padrões culturais diferenciados do restante da sociedade brasileira.

A etnogênese - que se coloca como oposto ao etnocídio enquanto extermínio sistemático de um estilo de vida - envolve a construção de uma "autoconsciência e identidade coletiva contra uma ação de desrespeito com vistas ao reconhecimento e à conquista de objetivos coletivos" (ARRUTI, 2006, p. 51).

Neste caso, o objetivo fundamental dos povos indígenas é o direito aos territórios historicamente ocupados ou a novos territórios e o respeito à diferença calcada no diálogo intercultural.

O movimento indígena iniciado no final do século XIX se fortaleceu ao longo do século

XX. A sua consolidação ocorreu até o final dos anos 1980, com marco na Assembleia Nacional Constituinte (1987-1988), onde o movimento indígena e o indigenista conseguiram forçar uma ruptura no modelo assimilacionista importado pelo Estado brasileiro aos povos indígenas.

Após a promulgação da nova Constituição brasileira, a continuidade do movimento indígena, na luta pela efetivação dos direitos garantidos legalmente, se ramifica em outras pautas de luta, sempre tendo como pilar a questão territorial, sustentáculo para o desenvolvimento dos povos.

No atual cenário de desafios econômicos, sociais, ambientais e políticos emerge a mulher indígena em papéis de liderança em suas comunidades e dentro do movimento indígena, que será tratado na próxima seção.

\section{EMPODERAMENTO FEMININO INDÍGENA NO MÉDIO E SUBMÉDIO SÃO FRANCISCO - BA}

Trazer à discussão a temática do empoderamento feminino indígena requer, preliminarmente, o entendimento desse conceito, cada vez mais presente em documentos oficiais e estudos acadêmicos na área de ciências sociais.

Baquero (2012, p.173) explicita ser o empoderamento (empowerment) um "anglicanismo que 
significa obtenção, alargamento ou reforço de poder", o qual vem sendo utilizado há poucas décadas indicando possibilidades de "emancipação do ser humano" (BAQUERO, 2012), a tomada de consciência coletiva e a superação de uma determinada situação, através da participação de espaços privilegiados de decisões em prol dos direitos sociais. (PEREIRA, 2006).

Para Horochovski e Meirelles (2007, p. 485), o termo empoderamento se aproxima da noção de autonomia na medida em que indivíduos e comunidades responsáveis controlam suas vidas, participando "[...] democraticamente no cotidiano de diferentes arranjos coletivos [compreendendo] criticamente seu ambiente".

A autonomia também se articula ao desenvolvimento autossustentável debatido por Gohn (2004) em que os sujeitos sociais se organizam de maneira colaborativa e cooperativa, interna e externamente, estabelecendo redes com movimentos sociais e organizações do terceiro setor, com trocas profícuas de conhecimentos, técnicas e tecnologias, ressignificando as práticas socioespaciais e engendrando continuamente novas territorialidades.

"Numa perspectiva emancipatória, empoderar é o processo pelo qual indivíduos, organizações e comunidades angariam recursos que lhes permitam ter voz, visibilidade, influência e capacidade de ação e decisão. Nesse sentido, equivale aos sujeitos terem poder de agenda nos temas que afetam suas vidas. Como o acesso a esses recursos normalmente não é automático, ações estratégicas mais ou menos coordenadas são necessárias para sua obtenção. Ademais, como os sujeitos que se quer ver empoderados muitas vezes estão em desvantagem e dificilmente obtiveram os referidos recursos espontaneamente, intervenções externas de indivíduos e organizações são necessárias, consubstanciadas em projetos de combate à exclusão, promoção de direitos e desenvolvimento, [...] com vistas à transformação das relações de poder de alcance nacional e global." (HOROCHOVSKI; MEIRELLES, 2007, p.486).

O próprio movimento indígena e sua consolidação no final do século XX favoreceu práticas de empoderamento dos diversos povos indígenas, aí incluídos os do Vale Sanfranciscano.

Conforme já abordado, a dinâmica socioterritorial do Vale vem passando por sucessivos ciclos, muitas vezes sobrepostos espaço temporalmente com características multiescalares, e, a partir do século XX, originados de políticas estatais relacionados ao desenvolvimento energético brasileiro.

Essa nova lógica de desenvolvimento territorial não considerou as características socioculturais dos povos tradicionais do Vale, tampouco buscou atender as reivindicações territoriais históricas dos povos indígenas.

Nesse contexto de complexificação territorial do Vale Sanfranciscano ao longo do século XX, o movimento indígena consolida-se no país apresentando um mosaico de reinvindicações de 305 etnias (IBGE, 2012), tendo como base comum a luta pelo direito e reconhecimento à diferença étnica e ao território.

Os povos indígenas nordestinos também participaram ativamente do movimento indígena em Brasília durante os anos 1987 - 1988 e, em várias aldeias do Vale, foram recolhidos relatos da participação de mulheres no movimento nesse período. A partir de então, existe uma grande permuta de experiências nos diversos encontros promovidos por órgãos indigenistas (FUNAI, SESAI, entre outros) e também pelo próprio movimento indígena, onde se observa a construção de aprendizagens significativas voltadas aos interesses desses povos.

As retomadas que ocorreram com bastante intensidade no Vale Sanfranciscano (BA, PE e AL) a partir da década de 1990 (MELLO; GERLIC, 2015) intensificaram as trocas sociais e experiências em diferentes funções pulverizando o que seria uma tradicional divisão sexual do trabalho, ampliando espaços de atuação e interlocução entre os agentes sociais, para além da questão de gênero.

Nesse contexto de luta histórica, homens e mulheres indígenas vem contribuindo para as conquistas que consideram justas e, necessárias, conforme reflete Ramos (2015, p. 21), indígena Pankararú da TI Entre Serras (PE): "nas questões indígenas, uma luta nunca está isolada das outras [...] a 
luta principal sempre será a terra, pois sem terra não há saúde, educação, [...] sustentabilidade. Portanto, todas as ações do movimento indígena são articuladas e colaborativas."

Luciano Baniwa (2006) ressalta que as mulheres indígenas têm funções socioeducativas fundamentais para a continuidade do grupo. Quer sejam em aldeias no norte do país com menor friç̧ão interétnica e mesclas culturais, quer seja na realidade nordestina, região de colonização antiga com grande hibridismo cultural e muitos deslocamentos territoriais. Em ambos os casos, a mulher indígena possui um papel relevante na manutenção cultural do grupo.

Segundo entrevistas realizadas no período 2013 - 2016 (COSTA, 2017), é recorrente a reflexão por parte de mulheres indígenas que ocupam cargos de liderança nas aldeias (caciques, agentes de saúde, professoras, entre outros) - de que o desenvolvimento está entrelaçado ao empoderamento da mulher indígena, em prol do fortalecimento das famílias e da comunidade, com geração de renda, revitalização de determinadas práticas culturais, da segurança alimentar, formação de professores indígenas e educação de qualidade.

Para os povos indígenas do Vale Sanfranciscano, além das pautas apresentadas, outros elementos entram em questão na discussão sobre gênero, pois são povos que estabelecem intensas trocas culturais com a sociedade envolvente desde o período colonial, e sua tradição,

cultura e função social de cada indivíduo apresentam maior maleabilidade em relação a grupos com menor fricção interétnica, como alguns povos da região norte do país.

$\mathrm{O}$ fato da presença de mulheres em cargos de liderança em várias aldeias, já é um indicativo de uma maior permeabilidade a modelos diversos de divisão sexual do trabalho que não aqueles rigorosamente estabelecidos na tradição indígena com pouca fricção interétnica, até mesmo porque, como anteriormente referenciado, os povos do Vale, através de longo contato com a sociedade não indígena experienciam outros modelos de divisão sexual do trabalho além de ressignificações de suas tradições.

A participação de mulheres no movimento indígena, sua articulação com outras instâncias da sociedade e no movimento indigenista toma contornos específicos na realidade nordestina, particularmente no médio e submédio São Francisco.

A partir desse recorte espacial, fora observada a presença de 14 caciques mulheres em 17 terras indígenas (TI) distribuídas em 05 municípios ${ }^{7}$. Os dados revelam uma expressiva densidade de caciques mulheres: em 13 das $17 \mathrm{TI}$, encontra-se pelo menos uma cacique mulher ${ }^{8}$ perfazendo $87 \%$ das TI.

Cumpre esclarecer que, do total de terras indígenas no médio e submédio São Francisco, Bahia, foram consideradas apenas 15 na obtenção do percentual de caciques mulheres por TI, pois nessas foi possível realizar o levantamento.

Nessas TI, a cacique com maior tempo de liderança é a Sra. Maria Kiriri, cacique desde 1989, um ano após a promulgação da nova Constituição brasileira, em um momento histórico onde as mulheres indígenas do norte do país estavam amadurecendo sua atuação no movimento indígena.

Ressalta-se, mais uma vez, a especificidade histórica e geográfica do Nordeste como área de colonização antiga, onde a intensidade de trocas favoreceram a emergência do cadinho de culturas ao qual Sampaio (1905) já fazia referência no início do século XX, incidindo inclusive, em novas formas e modelos de organizações sociais e construções de territorialidades.

A divisão sexual do trabalho em sociedades tradicionais possui contornos bem definidos, cabendo aos homens os cargos de liderança e de interlocução com as instâncias governamentais e movimento indigenista. No entanto, existem especificidades que podem indicar um caminho para compreensão da quantidade e importância das caciques mulheres (além de outras posições de liderança ocupadas por mulheres indígenas) na área estudada.

\footnotetext{
7 0 levantamento foi realizado utilizando dados do IBGE (2012), da FUNAI (http://www.funai.gov.br/index.php/indios-no- brasil/terras-indigenas) e de pesquisa em campo (2013 2016).
}

${ }^{8}$ Em uma TI podem coexistir dois ou mais caciques, não sendo uma regra fixa nas TIs pesquisadas. 
Dentre elas, vale sinalizar que no Nordeste as relações dos povos indígenas com a sociedade não indígena está situada historicamente no processo de formação e consolidação do território brasileiro, com forte carga de imposição cultural sobre os primeiros, portanto, as trocas e amálgama com a cultura e sociedade envolvente, favoreceram outras construções e representações de gênero, com reestruturações dos papéis para homens e mulheres.

Tais reestruturações não estão necessariamente relacionadas à instauração de conflitos ou rupturas étnicas nesses grupos sociais. Tampouco, a pleitos diretamente relacionados a questões de gênero.

O empoderamento de lideranças femininas, incluindo caciques mulheres, parte de demandas originadas no interior do próprio grupo social, onde se reconhece naquela mulher as condições e atributos necessários para que represente a comunidade externamente.

Não se tratam de mulheres conquistando espaços historicamente ocupados pelos homens ainda que tais discussões possam ocorrer no interior do movimento indígena; e sim o reconhecimento do grupo social e o respaldo espiritual sobre aquela mulher que, empoderada na condição de cacique, passa a ser reconhecida como "mãe de todos" e também como "guerreira", termo recorrentemente utilizado pelos indígenas ao se referirem às mulheres que estão em cargos de liderança nas aldeias.

Se, de um lado, a intensificação da presença dos capitais especulativos no Vale acentuou a precarização das condições de sobrevivência dos grupos sociais menos favorecidos, por outro lado, adensou os movimentos sociais de base, com uma significativa rede colaborativa em prol do efetivo desenvolvimento das populações tradicionais, envolvendo as Pastorais da Igreja Católica, Organizações Não Governamentais (ONG), pesquisadores e assessorias técnicas.

Cabe ressaltar, que os intercâmbios realizados possibilitam o contato com lideranças diversas, homens e mulheres, e que o trabalho desenvolvido por voluntários do movimento indigenista e pelas Pastorais junto às populações tradicionais, tem como princípio a formação de lideranças homens e mulheres - para que a comunidade possa se empoderar e buscar, com a maior autonomia possível, seus direitos, além de construir as bases do desenvolvimento considerando os seus valores materiais e espirituais.

Corroborando o exposto, Sacchi e Gramkow (2012) analisam o empoderamento de mulheres indígenas brasileiras indicando a atual dinâmica sociopolítica e econômica do país como responsáveis por tal transformação. Para as autoras (2012) a assunção de mulheres indígenas por suas famílias e comunidades está relacionada inclusive a questão territorial: territórios restritos e com pouca estrutura e ausência de alternativas econômicas. Essa análise se aproxima muito da realidade socioterritorial vivenciada pelas indígenas do Vale Sanfranciscano.

Uma outra especificidade a ser registrada é a emergência de novos grupos étnicos ou a formação de grupos a partir da Aldeia Mãe. Exemplificando, existem os Pankarú da Serra do Ramalho, BA oriundos da TI Pankararú, PE; os Pankararé Rodelas, que se deslocaram a partir da Aldeia Mãe no município de Glória, BA; e os Truká Tupan de Paulo Afonso, originários de Cabrobó, PE.

Tais grupos, mesmo apresentando um etnônimo próprio e lutando por um território, se consideram pertencentes ao grupo étnico de origem, apesar de gozarem de autonomia política e acabarem por apresentar novos traços culturais em suas práticas ritualísticas e territoriais. Tal emergência favoreceu o aumento do número de territórios indígenas ${ }^{9}$, os quais demandam o surgimento de novas lideranças nas comunidades localizadas no Vale.

Oliveira (1998) apontou a presença de 10 etnias na década de 1950 e, em 1994, 23 etnias no Nordeste. Dados de 2012 (IBGE, 2012) apontam 10 etnias ${ }^{10}$ somente no médio e submédio

\footnotetext{
${ }^{9}$ A maior quantidade de territórios não tem relação direta com a regularização fundiária dos mesmos. Várias Terras Indígenas (TI) continuam aguardando homologação, que é realizada pela presidência da república. Segundo relatório do Conselho Missionário Indigenista (2015, p. 45), a então gestão presidencial em exercício, foi a que menos procedeu a regularização fundiária desde o fim da ditadura militar, com um média anual de 2,7 homologações, contra a média de 10 homologações de seu antecessor. A maior média anual é verificada no período de 1991 a 1992, com 56 homologações/ano.
}

${ }^{10}$ Esse somatório refere-se apenas aos grupos étnicos e não a quantidade de Terras Indígenas (TI). Uma TI pode agrupar ou não mais de uma etnia, não existindo um padrão pré-fixado na organização desses grupos 
trechos do Vale Sanfranciscano no Estado da Bahia, e esse número aumenta para 19 etnias, ao considerar, nesses trechos, Pernambuco e Alagoas ${ }^{11}$.

Essa nova configuração socioespacial demanda a presença de lideranças a frente de cada comunidade, não sendo possível se fixar em modelos tradicionais (somente lideranças masculinas) quando para além das questões de gênero tais grupos estão mais ocupados em lutar por demandas de sobrevivência imediata e reprodução de seu modo de vida, tais como acesso à terra, saúde, educação, geração de renda e o direito de serem cidadãos diferenciados perante o Estado brasileiro (MATOS, 2012).

Os indicadores de uma possível abertura para novos modelos de divisão sexual do trabalho, com uma maior permeabilidade para a atuação de mulheres indígenas em atividades fora da esfera doméstica, incluindo aí atividades relacionadas a representação de seus povos em esferas públicas da sociedade não indígena, podem ser assim resumidos:

- $\quad$ Nordeste como área de colonização antiga. Maior fricção interétnica e processos de imposição cultural como mecanismo de aculturação e assimilação dos povos tradicionais;

-

Reordenamentos territoriais no Vale Sanfranciscano, principalmente a partir da segunda metade do século XX, com impactos profundos nos territórios tradicionais, incluindo perdas territoriais em razão da construção de barragens; e

- $\quad$ Etnogêneses ou formação de novos grupos étnicos a partir de um desmembramento do grupo étnico original.

Tais indicadores - fracionados com o propósito de fornecer maior clareza ao leitor sobre o empoderamento feminino indígena e o processo socioterritorial em curso - estão imbricados e, sua compreensão passa pelo entendimento de não ser possível propor uma regra ou uma tipologia que explique suficientemente quando e quais as razões pelas quais ocorreram uma ruptura entre um modelo tradicional da divisão sexual do trabalho, com cargos de liderança e representatividade do grupo social de responsabilidade exclusiva de pessoas do sexo masculino; e os novos modelos emergentes, com uma maior representatividade de mulheres liderando seu povo.

\section{CONSIDERAÇõES FINAIS}

A partir do que foi discutido nas diversas seções desse texto, buscou-se refletir sobre as questões de gênero e empoderamento feminino em uma perspectiva contemporânea, na qual a temática ganha expressividade em documentos de cunho internacional, entre eles, a Agenda 2030, em vigor desde 2015.

Nesse contexto, buscou-se evidenciar o discurso, presente na referida Agenda e documentos correlatos, da indissociabilidade existente entre o efetivo desenvolvimento sustentável e a superação das questões históricas que impedem o pleno desenvolvimento de mulheres e meninas.

Em seguida, a geo-história dos povos indígenas no Vale Sanfranciscano foi retratada, criando o embasamento para compreensão do empoderamento feminino no médio e submédio São Francisco, BA, onde foi realizada a pesquisa.

Por fim, foi possível trazer à discussão a trajetória de empoderamento de mulheres pertencentes a vários povos indígenas na área de estudo, onde se destaca o papel da cacique, cuja representatividade - são quatorze - denota que para os povos pesquisados não é possível prosseguir com suas pautas reivindicatórias junto ao Estado, sem a efetiva participação da mulher.

De fato, as lutas engendradas por esses povos e suas conquistas são imbricadas pela participação

étnicos.

${ }^{11}$ Atikum, PE, BA; Catokin, AL; Geripankó, AL; Kalankó, AL; Kambiwá, PE, BA; Kantaruré, BA; Karuazú, AL; Kiriri, BA; Pankaiuká, PE; Pankará, PE; Pankararé, BA; Pankararú, PE; Pankarú, BA; Pipipã, PE; Truká, PE, BA; Truká Tupan, BA; Tumbalalá, BA; Tuxá, BA; Xucuru-Kariri, AL. (IBGE, 2007) 
feminina, e a memória e conhecimento gerado a partir daí revela-se como parte inalienável do patrimônio cultural imaterial desses povos.

Tal reposicionamento, cuja leitura na sociedade não indígena se daria em torno de uma maior representatividade política da mulher no contexto societário, demonstra caminhos para a construção da equidade de gênero. E esta insere-se como prioritária nos Objetivos do Desenvolvimento Sustentável (ODS), sem a qual dificilmente se atingirá as metas previstas para 2030.

\section{REFERÊNCIAS}

[1] Arruti, José Maurício Andion. Morte e vida do Nordeste Indígena: a emergência étnica como fenômeno histórico regional. Estudos Históricos, Rio de Janeiro, v. 8, n. 15, 1995, p. 57-94.

[2] . Ricardo, Beto; RICARDO, Fany. (Ed.). Etnogêneses Indígenas. Povos indígenas do Brasil: 2001 2005. São Paulo: Instituto Socioambiental, 2006. p. 50 - 54.

[3] Baquero, Rute Vivian Angelo. Empoderamento: instrumento de emancipação social? uma discussão conceitual. Revista Debates, Porto Alegre, v. 6, n. 1, p.173-187, jan.-abr. 2012. Disponível em: <http://www.seer.ufrgs.br/debates/article/viewFile/26722/17099>. Acesso em: 1 nov. 2016.

[4] Brasil. Governo Federal. O Brasil e os objetivos de desenvolvimento do milênio. Disponível em: <http://www.odmbrasil.gov.br/o-brasil-e-os-odm>. Acesso em: Acesso em: 07 de out. 2017.

[5] Brasil, Governo Federal; Organização das Nações Unidas. Objetivos de Desenvolvimento Sustentável. Disponível em:<http://www.itamaraty.gov.br/images/ed_desenvsust/ODSportugues12fev2016.pdf>. Acesso em 14 jun. 2017.

[6] Costa, Gisele das Chagas. Construção de territorialidades indígenas e suas inter-relações com o empoderamento feminino no Médio e Submédio São Francisco - Ba. Tese de Doutorado. Salvador: Programa de Pós Graduação em Desenvolvimento Regional e Urbano, Universidade Salvador. Salvador: UNIFACS, 2017. 139 f.

[7] Dias, Reinaldo. Gestão Ambiental: responsabilidade social e sustentabilidade. 2. e. São Paulo: Atlas, 2011.

[8] Gohn, Maria da Glória. 2004. Empoderamento e participação da comunidade em políticas sociais. Disponível em: <http://www.revistas.usp.br/sausoc/article/view/7113>. Acesso em: 12 jun. 2014.

[9] Horochovski, Rodrigo Rossi; Meirelles, Giselle. Problematizando o conceito de empoderamento. In: Seminário Nacional Movimentos Sociais, Participação E Democracia, 2., 2007, Florianópolis: UFSC. . Anais... 2007. p. 485 - 506.

[10] Instituto Brasileiro de Geografia e Estatística. IBGE. Censo Demográfico 2010: características gerais dos indígenas: resultados do universo. Rio de Janeiro: IBGE, 2012.

[11] Luciano Baniwa, Gersem dos Santos. O Índio Brasileiro: o que você precisa saber sobre os povos indígenas no Brasil de hoje. Brasília: Ministério da Educação, Secretaria de Educação Continuada, Alfabetização E Diversidade; Laced/Museu Nacional, 2006.

[12] Martin, Gabriela. O povoamento pré-histórico do Vale do São Francisco (Brasil). 1998.

[13] Disponível em: <https://www.ufpe.br/clioarq/images/documentos/1998- N13/1998a1.pdf>. Acesso em: 13 jan. 2014.

[14] Matos, Maria Helena Ortolan. Mulheres no movimento indígena: do espaço de complementariedade ao lugar da especificidade. In: SACCHI, Ângela; GRAMKOW, Márcia Maria. Gênero e povos indígenas. Rio de Janeiro, Brasília: MUSEU DO ÍNDIO/ GIZ/ FUNAI, 2012. p. 140 - 171.

[15] Mello, Gabriela Saraiva de; Gerlic, Sebastián. (Org.). 2015. Memórias do Movimento Indígena do Nordeste. Disponível em: <http://www.thydewa.org/wp- content/uploads/2015/03/Livro-MovimentosCartograficos-Final_web.pdf>. Acesso em: 25 nov. 016.nascimento, Marco Tromboni de. O povo indígena Kiriri. In: Silva, A. L. da; Grupioni, L.

[16] D. B. (Orgs.). A temática indígena na escola: novos subsídios para professores de 1o e 2o graus. Brasília: MEC, Mari, Unesco, 1995. p. 67 - 72.

[17] Oliveira, João Pacheco de. Uma etnologia dos "índios misturados"? Situação colonial, territorialização e fluxos culturais. 1998.Disponível em:<http://www.scielo.br/pdf/mana/v4n1/2426.pdf>. Acesso em: 12 jan. 2013.

[18] Organização das Nações Unidas. 2010. Objetivos de desenvolvimento do milênio. Disponível em: <http://www.un.org/en/mdg/summit2010/>. Acesso em: 05 de out. 2017. 
[19] Organização das Nações Unidas. Objetivos de desenvolvimento do milênio. Disponível em:< https://nacoesunidas.org/tema/odm/>. Acesso em: 05 de out. 2017.

[20] ORGANIZAÇÃO das Nações Unidas. ONU Mulheres. Mulheres Indígenas: Voz das Mulheres Indígenas. Disponível em: <http://www.onumulheres.org.br/mulheres-indigenas/>. Acesso em 13 maio 2016.

[21] .Planeta 50-50 em2030. Disponível em:<http://www.onumulheres.org.br/planeta5050/>. Acesso em 10 out. 2017.

[22] Portal Objetivos de Desenvolvimento do Milênio. Relatórios dinâmicos: Bahia: objetivo 3: promover a igualdade entre os sexos e a autonomia das mulheres. Disponível em:

[23] <http://www.relatoriosdinamicos.com.br/portalodm/3-igualdade-entre-sexos-e- valorizacao-damulher/BRA002029/bahia>. Acesso em: 23 maio 2017.

[24] ramos, Elisa Urbano. Memórias que educam. In: Mello, Gabriela Saraiva de; GERLIC, Sebastián. (Org.). Memórias do Movimento Indígena do Nordeste. 2015. p. 19 - 21. Disponível em: <http://www.thydewa.org/wp-content/uploads/2015/03/LIVRO- Movimentos-CartograficosFINAL_web.pdf>. Acesso em 25 nov. 2016.

[25] Sacchi, Ângela; Gramkow, Márcia Maria. Introdução. In:. Gênero e povos indígenas.

[26] Rio de Janeiro; Brasília: Museu do Índio/ GIZ/ Funai, 2012. p. 15 - 27.

[27] Sachs, Ignacy. Caminhos para o desenvolvimento sustentável. Porto Alegre: Garamond, 2002.

[28] Sampaio, Theodoro. O Rio São Francisco e a Chapada Diamantina. Salvador: Escolas Profissionais Salesianas, 1905. Salvador: Instituto Geográfico e Histórico da Bahia, 1998. (fac simile da primeira edição).

[29] Santos, Juracy Marques dos. Cultura material e etnicidade dos povos indígenas do São Francisco afetados por barragens: um estudo de caso do Tuxá de Rodelas, Bahia, Brasil. Tese de Doutorado. Salvador: Programa de Pós-Graduação em Cultura e Sociedade, Universidade Federal da Bahia, 2008. 367 p. Disponível em:<https://repositorio.ufba.br/ri/bitstream/ri/10835/1/tese_Juracy\%20Marques1.pdf>. Acesso em: 23 jan. 2014.

[30] Souza, Regina Celeste de Almeida; RAMOS, Alba Regina Neves. Rio São Francisco: cultura, identidade e desenvolvimento. Revista de Desenvolvimento Econômico - RDE, ano XII, p. 05 - 13, dez. 2010.

[31] Tomáz, Alzení de Freitas et al. (Org.). 2008. Povos indígenas do Nordeste impactados com a transposição do Rio São Francisco: relatório de denúncia. Disponível em:<http://www.cimi.org.br/pub/publicacoes/1241549933_relatapoinmetransp.pdf>. Acesso em: 31 out.2016. 


\section{Capítulo 8}

A produção e a estocagem das sementes da paixão como forma de resistência ao modelo capitalista na produção agrícola: O caso do assentamento Três Irmãos - Triunfo, PB.

Juliano Moreira do Nascimento

Resumo: Desde que aprendeu a dominar as técnicas de plantio e cultivos agrícolas, o ser humano, a partir das observações, interpretações e registros das mudanças que ocorriam na natureza e nos fenômenos atmosféricos, desenvolveu formas de adaptação e alteração do meio natural, humanizando-o. A agricultura surgiu há cerca de dez mil anos atrás, sendo importante para a fixação e desenvolvimento das sociedades, e na transformação do espaço geográfico associada à estocagem e produção de excedentes. Desse modo, durante milhares de anos, pequenos produtores camponeses de diversos lugares do mundo vêm dando continuidade à tradição de plantar e estocar uma diversidade de espécies alimentícias (policultura) usadas como garantia de subsistência das comunidades locais. No Brasil, principalmente no Nordeste, a tradição da estocagem de sementes foi fortemente impactada pelas novas técnicas introduzidas pela modernização agrícola, entretanto, ainda se mantém como uma forma de garantia de alimentação em tempos de estiagem e de sementes de qualidade para o plantio na época certa. No estado da Paraíba a prática tradicional da policultura associada ao modelo de agricultura familiar, se destaca pela valorização dos insumos naturais locais, adaptados às condições edafoclimáticas de cada mesorregião. As sementes comumentes chamadas de crioulas ou naturais, são reconhecidas como "sementes da paixão", e fazem parte de projetos que envolvem o plantio, a seleção e estocagem. Na mesorregião do Sertão paraibano, o contexto das sementes da paixão está vinculado à muitas histórias de vida dos camponeses. Este trabalho aborda algumas das informações, discussões e resultados que foram apresentados na dissertação intitulada: "Os Bancos de Sementes Comunitários na construção dos territórios de esperança: o caso do Assentamento Três Irmãos/PB", aprovada pelo Programa de Pós-Graduação em Geografia (PPGG) da Universidade Federal da Paraíba (UFPB) e apresentou como resultado um estudo da resistência camponesa ao processo de dominação do capital na agricultura, através da recuperação da luta pela terra e a da construção do Banco de Semente Comunitário (BSC) do Assentamento Três Irmãos, localizado próximo a cidade de Triunfo, na microrregião de Cajazeiras. Essa comunidade é composta por 74 famílias, distribuídas em 07 glebas: Três Irmãos, Saco, Tabuleiro Grande, Croá, Carretão, Mulunguzinho e Vertente. A metodologia utilizada foi quanti-qualitativa - bibliográfica e documental - além de pesquisas de campo; o método foi o materialismo histórico e dialético e como objetivos específicos: a) rediscutir as acepções sobre território, desenvolvimento rural e práticas agrícolas sustentáveis, enquanto categorias de fundamentação e análise teórica; b) resgatar o processo histórico de formação territorial do Sertão paraibano à luz do desenvolvimento desigual e combinado do capitalismo no campo; c) recuperar e discutir o processo histórico de construção do território do Assentamento e do BSC Três Irmãos (Triunfo - PB); d) entender a dinâmica social, econômica, cultural e política dos Bancos de Sementes e seus reflexos sobre o território. A partir dessa experiência coletiva, estes contribuem para a negação do processo histórico de mudanças pelos quais os sujeitos sociais envolvidos com a questão agrária vivenciaram nessa região, principalmente como uma forma de resistência ao modelo capitalista de produção agrícola. Conclui-se que a cultura de estocagem de sementes representa uma forma de resistência aos impactos negativos no campo, causados pelo modelo capitalista vigente; contribui para o fortalecimento dos territórios de esperança através da partilha de sementes e dos conhecimentos dos camponeses sobre suas localidades; colabora com o 


\section{PARA INÍCIO DE CONVERSA}

A história do campesinato no Brasil é marcada por lutas e resistência, sejam elas contra as limitações climáticas, as relações patronais e/ou a total subordinação ao capitalismo. Na busca pela reterritorialização e a procura por novos territórios para morar e produzir seus alimentos, de forma natural e saudável, os camponeses se uniram aos movimentos sociais, sindicatos rurais, entre outras entidades, para lutarem pelo que lhes são de direito. Pode-se observar em várias comunidades camponesas o trabalho de resgate às tradições agrícolas que valorizam 0 protagonismo familiar, o meio ambiente, a coletividade e a preservação da biodiversidade.

A agricultura camponesa está inserida em um processo de resistência e luta pela terra, seguindo um caminho inverso às discussões capitalistas (que pregam a modernização agrícola, o latifúndio, associados aos insumos químicos e ao domínio e patenteamento da biodiversidade). A relação dos camponeses com a agricultura é resultado de experiências a partir do contato com o meio natural e de conhecimentos acumulados através dos tempos, repassado para os demais membros da família, que se mantêm presentes em todo o processo de produção alimentar, fortalecendo a aproximação entre estes e outros membros da comunidade local (Almeida 2003).

No sertão da Paraíba, os movimentos de luta pela terra têm ganhado destaque não só pela conquista da terra em si, mas, pelo desenvolvimento de experiências locais, a exemplo da estocagem de sementes da paixão.

Este trabalho aborda algumas das informações, discussões e resultados que foram apresentados na dissertação intitulada: "Os Bancos de Sementes Comunitários na construção dos territórios de esperança: o caso do Assentamento Três Irmãos/PB", aprovada pelo Programa de Pós-Graduação em Geografia (PPGG) da Universidade Federal da Paraíba (UFPB) e apresentou como resultado um estudo da resistência camponesa ao processo de dominação do capital na agricultura, através da recuperação da luta pela terra e a da construção do Banco de Semente Comunitário (BSC) do Assentamento Três Irmãos, localizado próximo a cidade de Triunfo, na microrregião de Cajazeiras, na Paraíba. Essa comunidade é composta por 74 famílias, distribuídas em 07 glebas: Três Irmãos, Saco, Tabuleiro Grande, Croá, Carretão, Mulunguzinho e Vertente.

A metodologia utilizada foi quanti-qualitativa - bibliográfica e documental - além de pesquisas de campo; o método foi o materialismo histórico e dialético, e apresentou como objetivos específicos: a) rediscutir as acepções sobre território, desenvolvimento rural e práticas agrícolas sustentáveis, enquanto categorias de fundamentação e análise teórica; b) resgatar o processo histórico de formação territorial do Sertão paraibano à luz do desenvolvimento desigual e combinado do capitalismo no campo; c) recuperar e discutir o processo histórico de construção do território do Assentamento e do BSC Três Irmãos (Triunfo - PB); d) entender a dinâmica social, econômica, cultural e política dos Bancos de Sementes e seus reflexos sobre o território.

\section{A AGRICULTURA, o MODELO CAPITALISTA E A RESISTÊNCIA DO CAMPESINATO}

Desde que aprendeu a dominar as técnicas de plantio e cultivos agrícolas, o homem observou as mudanças que ocorriam na natureza e, dessa leitura, desenvolveu formas de adaptação importantes para a produção de alimentos direcionados ao consumo familiar. 0 cuidado com o material orgânico, com as técnicas de convivência dentro de padrões e limites impostos pela natureza foram importantes para o melhoramento na produção de alimentos. Assim, as relações de proximidade com a terra foram estreitadas, fixando-os em uma determinada fração do espaço.

De acordo Almeida e Freire (2003):

De olhos atentos ao seu mundo, comunidades de agricultores vem observando seu meio, a natureza, seus elementos e mecanismos; vem assim inventando e reinventando sua realidade e construindo um repertório de conhecimentos que permite, como as sementes, germinar e frutificar espaços socioculturais, expressão legítima de suas formas de 
atuar. As sementes, antes portadoras de mensagens biológicas, carregam agora novos significados. Fazem germinar roçados, mas também fazem crescer um conjunto de saberes, resultado de um intenso processo de pesquisa, seleção e troca realizados pelos agricultores (p. 280).

Durante muito tempo, os camponeses foram os protagonistas do processo de produção de alimentos, atuando desde a seleção de sementes até a colheita de seus produtos, reforçando uma relação de harmonia com a terra e com os demais camponeses. Karl Marx observa que:

os alimentos que excediam das produções podiam ser guardados, estocados e reservados para suprir as necessidades da população em épocas de colheitas ruins. A tradição pela conservação dos alimentos sempre teve importância para a formação da sociedade humana em vários momentos da história. (MARX, 1975, p. 861)

Como podemos perceber, para o camponês, a tradição de seleção e (re) produção de sementes naturais tem como finalidade assegurar a qualidade dos alimentos e garantir a subsistência de sua família. Todavia, com a ascendente expansão capitalista no campo, que culminou com o processo de "modernização conservadora da agricultura" na década de 1970, os maiores beneficiados foram os grandes latifundiários que, valorizados pelo modelo conhecido como Revolução Verde, automaticamente excluíram os pequenos produtores de suas terras, no qual não tinham meios de se inserir no mercado competitivo (SILVA, 2003, p. 59).

Em suas análises sobre o capitalismo, Karl Marx explica que:

0 processo que cria o sistema capitalista consiste apenas no processo que retira ao trabalhador a propriedade de seus meios de trabalho, o processo que transforma em capital os meios sociais de subsistência e os de produção e converte em assalariados os produtores diretos (...). 0 processo que produz o assalariado e o capitalista tem suas raízes na sujeição do trabalhador. 0 processo consistiu numa metamorfose da sujeição, na transformação da exploração feudal em exploração capitalista (MARX, 1975, p. 830).

Para Marx, o processo de expansão capitalista que intensifica o assalariamento dos camponeses resultaria no fim do campesinato. Chayanov (1966), por sua vez, tentou mostrar em seus trabalhos que "as leis do capitalismo" não podem ser atribuídas a todas as formas de economia e que as leis de mercado (lucro) não são encontradas quando a produção está voltada para o consumo familiar. Rosa Luxemburgo (1983) observou que o capital não poderia resistir sem que houvesse uma parte da sociedade não-capitalista que estivesse inserida diretamente na dinâmica do capitalismo, pois estes seriam a classe consumidora de seus produtos, o que manteria o mercado.

De acordo com Oliveira (1997, p.49), o foco principal do desenvolvimento do modo capitalista de produção no campo brasileiro está "na sujeição da renda da terra ao capital, pois a partir daí, ele tem as condições necessárias para sujeitar também o trabalho que se dá na terra". Assim, observamos que a retirada dos camponeses de suas terras, obriga-os a vender seu bem mais importante, sua mão-de-obra.

Entretanto, por mais devastador que seja, o sistema capitalista abre brechas para o surgimento de outras formas de sobrevivência. Ao mesmo tempo em que exerce domínio, gera situações onde o camponês recorre a outros meios para manter a subsistência familiar e econômica.

Decerto, ao separar o produtor camponês de suas terras, o capitalismo contribui para o enfraquecimento das relações de identidade que este tem com o seu território, deste modo, com o tempo perdem-se a conservação de seus valores sociais e culturais.

\section{AS DISPARIDADES NA PRODUÇÃO AGRÍCOLA BRASILEIRA}

A respeito da agricultura no Brasil, percebemos que, a década de 1960 marcou uma mudança nas estruturas econômicas e produtivas, movimentada pela ditadura militar. Na pauta das discussões do governo destacam-se os rumos do desenvolvimento econômico brasileiro, que tinha como propósito retomar a corrida pela industrialização iniciada na década de 1930. Contudo, dessa vez, a política industrial não poderia acontecer caso não houvesse profundas modificações no meio rural. 
Mudanças estas que tiveram o apoio do Estado e dos que defendiam e apostavam que a modernização rural/industrial não necessitava de uma reforma agrária, ou seja, a "salvação do Brasil" não estava na divisão de terras e sim na concentração territorial nas mãos de um número mínimo de latifundiários.

De acordo com Nogueira, (2005):

O país explodiu em termos capitalistas. Expandiu suas forças produtivas, estatizou-se como nunca dantes, internacionalizou sua economia, dinamizou sua agricultura e se industrializou. Movimentou-se freneticamente para todos os lados. Em vinte anos, tornou-se outro: mais capitalista, mais moderno, mais deformado e injusto, radicalizando uma tendência que vinha se acentuando desde a década de 50. (...) A desigualdade social e a injustiça na distribuição da renda cresceram na mesma proporção em que a economia capitalista se fortaleceu. (p. 17-18)

A chegada da modernização no campo brasileiro tornou-se atração pela rapidez e praticidade nas formas de cultivo desenvolvidas em países como os EUA. Existia uma propaganda de disseminação de produtos agroindustriais nos países subdesenvolvidos, guiados pelo "exemplo de modernidade" americano. Essas novas ideias eram complementadas pela concepção de que o aumento da produção seria suficiente para atender à necessidade alimentar dos brasileiros, acabando assim, com a fome e a desigualdade social (SILVA, 2001). Entretanto, a própria história nos mostra que essa melhoria nunca aconteceu.

Segundo Graziano da Silva, a tecnificação das formas de produção no campo:

(...) coloca, necessariamente, os pequenos produtores na concorrência intercapitalista, tanto no mercado de produtos como no de insumos. E a sua capacidade de sobrevivência passa a ser determinada pela competição intercapitalista nesses mercados. É uma "corrida" cujo ritmo é dado pela acumulação e, por mais que corram, são poucos os que conseguem ao menos manterem-se no mesmo lugar, ou seja, sobreviver como pequenos produtores (2003, p.59).

Como dito anteriormente, a modernização no campo teve como carro-chefe as exportações agrícolas estadunidenses, e chegou ao Brasil com o nome de Revolução Verde. Suas técnicas de produção, aliadas a produtos químicos, beneficiavam as grandes empresas de agronegócios que se espalhavam pelo mundo e contribuiu para o aumento da desigualdade (MITTAL E ROSSET, 2003, p.175). Algumas empresas de agrotóxicos, visando expandir seus negócios, aliaram-se a uma visão de domínio sobre a produção de alimentos, comprando a maioria das empresas que produziam sementes, criando as chamadas "companhias de ciências da vida" que, através de técnicas de manipulação genética, procuraram, de forma maquiada, exercer domínio sobre a produção e o consumo alimentar da população. Importantes empresas podem ser destacadas como: Monsanto, Giga-Geigy, Hoecshst, Aventis, Novartis e Syngenta

O camponês tornou-se um escravo dessas empresas, pois além de pagar pelas sementes, e obrigado a adquirir também os insumos tóxicos que, em sua maioria, são vendidos em pacotes especiais, com preços "acessíveis" que "beneficiam" a produção de alimentos (ALTIERI e NICHOLLS, 2003, p.164).

Nas concepções de Mittal e Rosset (2003), a relação desigual entre dominador e dominado intensifica-se quando os problemas de saúde pública, causados pelo consumo de alimentos geneticamente alterados e/ou produzidos com insumos tóxicos, causam doenças como alergias, intoxicação alimentar, entre outros distúrbios que afetam grande parte da população. Por outro lado, essa mesma população busca "a cura" através de remédios, muitas vezes, produzidos pela mesma empresa que "criou" a semente e produziu o adubo/veneno, fechando um ciclo de dominação alimentar. Algumas empresas como a Bayer e a Monsanto podem ser lembradas nessa discussão.

A partir do momento em que os camponeses optam por usar em seus roçados as sementes da paixão e não as que são disponibilizadas pelo mercado, criam barreiras que impedem a sua total absorção pelo modelo vigente de agricultura, principalmente o agronegócio.

Os Bancos de Sementes Comunitários são experiências alternativas a essa agricultura de mercado e vêm ganhando destaque dentro dos Assentamentos, das entidades como a ASA- PB (Articulação do 
Semiárido Paraibano) e a AS-PTA (Assessoria e Serviços a Projetos em Agricultura Alternativa), e da CPT/Sertão (Comissão Pastoral da Terra/Sertão). Na Paraíba, este trabalho em conjunto resultou em um grande evento e um importante espaço de discussão mais ampla, as Festas Estaduais das Sementes da Paixão (FESP). No entanto não iremos nos aprofundar nestes encontros, já que a descrição de todas FESP podem ser encontradas no trabalho principal, no qual este se baseia.

\subsection{BANCO DE SEMENTES COMUNITÁRIO DO ASSENTAMENTO TRÊS IRMÃOS}

O capitalismo em sua contradição, ao mesmo tempo em que expulsa o camponês de suas terras com a finalidade de torná-lo um assalariado, também desperta nestes uma resistência a essas forças dominantes. A respeito da resistência social camponesa, Carvalho (2003) explica que é necessário um processo prolongado de resgate das identidades sociais, que exija uma:

redescoberta de seus saberes, habilidades e práticas de produzir, de se alimentar e de cuidar da saúde, experiências essas de vida que "rejeitaram" porque lhes disseram que eram saberes e fazeres ultrapassados" (p.108) (grifo nosso).

Além de assegurar a subsistência da família - não só alimentar como também econômica - a estocagem de sementes da paixão é importante para a recuperação e multiplicação dos recursos genéticos locais, que garantem uma flexibilidade de opções através de um sistema de policultura contrapondo-se a discussão capitalista que apoia a monocultura.

A introdução da experiência de um banco de sementes comunitário nas comunidades paraibanas trouxe consigo um discurso de conscientização sobre os impactos causados pelo uso de insumos tóxicos nos roçados. A partir de então, muitos agricultores passaram a produzir de forma natural e sustentável. Segundo os dados da Rede Sementes da Paraíba, o estado possuía em 2006 o número de 476 silos, 228 BSC e contava com a participação de 6.561 famílias associadas, distribuídas em 61 municípios. Diante das estratégias desenvolvidas por estes camponeses, destacam-se os bancos de sementes: comunitários (BSC) e os familiares (BSF).

No BSC, os estoques são disponibilizados tanto aos camponeses das comunidades que possuam o banco, quanto para outras áreas, como as de assentamento que possam vir a necessitar de sementes para consumo ou plantio, obedecendo a uma regra de devolução. 0 empréstimo de sementes, de acordo com a política do BSC, acontece da seguinte forma: cada família recebe uma determinada quantia de sementes - de acordo com o tamanho e as necessidades das famílias - e utilizam-nas no período de plantio ou para consumo próprio. No período de colheita devolve a quantia solicitada ao banco acrescida de $20 \%$ (o valor é estabelecido pela coordenação dos bancos). Esse método garante um estoque sempre farto.

No caso dos BSF, algumas famílias camponesas optam por estocar as sementes de forma caseira, em garrafas PET, contribuindo para a reciclagem e preservação do meio ambiente. Essa reserva é utilizada em momentos de dificuldades econômicas, sendo vendidos diretamente no mercado ou através de atravessadores. Um bom exemplo de Banco Familiar é o de Dona Mariana, que guarda as suas sementes dentro de silos, em um quartinho e também em diversas garrafas empilhadas nos vãos da casa.

É importante ressaltar que o alimento que excede da produção destes bancos de sementes é vendido em feiras agroecológicas ou em feiras livres, localizadas nas cidades circunvizinhas, contribuindo na complementação da renda familiar dos agricultores. A estocagem de sementes também garante uma segurança diante dos programas de distribuição de sementes do governo, que em sua maioria chegam aos agricultores depois do período de chuvas na região, além disso, enfraquece as relações de domínio pelos políticos que oferecem sementes em troca de votos (Almeida, 2001).

Segundo Almeida (2001) os primeiros relatos desta experiência comunitária no Brasil, aparecem na região Nordeste na década de 1970, graças ao trabalho da Igreja Católica junto as Comunidades Eclesiais de Base (CEBs). A primeira experiência de BSC registrada na Paraíba surge no ano de 1992, no Assentamento Três Irmãos, logo após a conquista e posse do direito de uso das terras, contando com o apoio da CPT/Sertão e de um projeto da Caritas Brasileira, que liberou recursos para a comunidade construir casas e poços, comprar carroças e animais. 
As sementes que foram o pontapé do BSC foram compradas pelos próprios camponeses nas cidades vizinhas como Cajazeiras/PB e Triunfo/PB, cerca de 2.250 quilos, entre arroz, feijão e milho que foram estocados em 02 silos (também comprados com o recurso da Caritas).

Com o apoio e o acompanhamento da CPT/Sertão, os assentados passaram a discutir em suas reuniões, alguns temas como agroecologia, os problemas causados a partir do uso de insumos químicos na produção, e propostas para estimular a união e a solidariedade entre eles. Essa união pode ser identificada nos vários mutirões ressaltados durante as entrevistas, que eram momentos em que os camponeses se juntavam para dividir tarefas, como, a limpeza, o plantio e a colheita na roça comunitária.

O BSC serve como uma alternativa à dependência dos camponeses aos políticos e as prefeituras, libertando-os do assistencialismo ainda fortalecido na região semiárida do Sertão Paraibano. 0 fato de não precisarem de ajuda externa quando se tratam de sementes para o plantio e alimentação, os camponeses de Três Irmãos resistem a dominação imposta pelas multinacionais ou pelo Programa de Distribuição de Sementes do governo. Assim, reduzem o nível de dependência a esses Programas que distribuem as sementes nos períodos em que as chuvas já têm passado, e os camponeses já tenham plantado ou já estejam próximos de colher a sua produção.

Além de sua importância como garantia de semente para alimentação e para o plantio, o BSC de Três Irmãos representa um espaço de discussão política, cultural e ambiental, onde as suas tradições são respeitadas e os limites naturais são contornados, mas sem que aja agressão ao meio ambiente.

A história das sementes da paixão, muitas vezes, mistura-se a dos camponeses. Muitos deles guardam seus insumos naturais, dando continuidade aos cuidados e a dedicação de seus familiares por anos, contribuindo não só para a preservação da agro biodiversidade local, como também para a construção do conhecimento, da melhoria das experiências na produção de alimentos naturais e na garantia da soberania alimentar.

As sementes da paixão representam a preservação da memória camponesa, pois é o resultado de muitos testes e observações nos seus roçados, em um processo de seleção e plantio das melhores sementes, garantindo, assim, a melhoria e a perpetuação da qualidade desses insumos naturais.

\section{CONSIDERAÇÕES FINAIS}

Observamos, de modo geral, que o enfraquecimento das relações entre o camponês, as sementes e o seu território se deve basicamente a modernização no campo e a concentração das terras nas mãos de uma minoria da sociedade. Tais fatores foram associados a manipulação genética dos alimentos promovidos pela expansão do capital na agricultura junto ao uso de insumos químicos que apenas beneficiam para a lucratividade das multinacionais.

Entretanto, as experiências de Bancos de Sementes da Paixão no Assentamento Três Irmãos nos mostra que, de forma organizada, eles garantem uma certa segurança quanto a disponibilidade de sementes para plantio e alimentação. As sementes são escolhidas e as melhores são guardadas em silos, garrafas plásticas ou de vidro (contribuindo para a preservação do meio ambiente). Após a criação do banco de sementes nesta comunidade, aprofundaram-se as discussões a respeito da segurança alimentar, da agroecologia e do desenvolvimento sustentável, levando muitos dos camponeses a abandonar o uso de insumos químicos, principalmente o veneno.

Quando analisamos em um contexto maior, percebemos que eles resistem ao modelo agrícola capitalista, pois não dependem da distribuição de sementes do governo (que são distribuídas após o período de plantio) e nem precisam comprar as sementes vendidas pelas empresas multinacionais. Ao passo que não necessitam de produtos externos (fertilizantes, herbicidas, agrotóxicos), contribuem para o enfraquecimento das vendas dessas empresas.

Possuir um banco de sementes é preservar a biodiversidade e a tradição da produção e consumo de alimentos naturais, dando mais autonomia ao camponês nas escolhas do que plantar e/ou comer.

Percebemos também que a união entre os camponeses e os movimentos sociais e sindicatos rurais, faz com que experiências e discussões como essas sejam expandidas para todo o Estado, chegando a todos que moram na cidade ou no campo. 0 Banco de Sementes Comunitário de Três Irmãos, por se tratar de um dos primeiros focos de estocagem comunitária de sementes na Paraíba, serviu e ainda 
serve como base para a criação de novos bancos de sementes nos assentamentos do estado em outras regiões do Brasil.

\section{REFERENCIAS}

[1] Almeida, Paula e Cordeiro, Ângela. Sistema de seguridade da semente da paixão: estratégia comunitária de conservação de variedades locais no semiárido. Rio de Janeiro: AS-PTA, 2001.

[2] Almeida, Paula e Freirei, Adriana Galvão. Conservando as sementes da paixão: duas histórias de vida, duas sementes para a agricultura sustentável na Paraíba In. Sementes: Patrimônio do povo a serviço da humanidade. 1. ed. São Paulo: Expressão Popular, 2003.

[3] Altieri, Miguel A. e Clara I. Nicholls. Sementes nativas: patrimônio da humanidade essencial para a integridade cultural e ecológica da agricultura camponesa. In. Sementes: Patrimônio do povo a serviço da humanidade. 1. ed. São Paulo: Expressão Popular, 2003.

[4] Carvalho, Horácio Martins de (org). Sementes: Patrimônio do povo a serviço da humanidade. 1. ed. São Paulo: Expressão Popular, 2003.

[5] Chayanov, Alexander V. On the theory of peasant economy. Womewood, III: Richard D Irwin, 1966

[6] Holanda, Sergio Buarque de. Raízes do Brasil. 6a edição, Rio de Janeiro, Jose Olympio, 1971. Cap. V - 0 homem cordial (p. 101-112); Cap. VI - Novos tempos (p. 113-125); e Cap. VII - Nossa revolução (p. 126-142).

[7] Luxemburg, Rosa. A acumulação de capital. 3. Ed. Rio de Janeiro: Zahar, 1983.

[8] Marx, Karl. 0 capital: critica da economia política. Rio de Janeiro: Editora Civilização Brasileira,1975.

[9] Moreira, Emília e Targino, Ivan. Capítulos de Geografia Agrária da Paraíba. Joao Pessoa: Editora Universitária, UFPB, 1997.

[10] Nascimento, J. M., Moreira, Emília. Sementes da Paixão: estratégia de reprodução da agricultura familiar no Alto Sertão Paraibano. In: Semiluso - Seminário Luso Brasileiro, Ano II, 26 a 28 de junho de 2008, Joao Pessoa, PB. Editora Universitária UFPB, 2008.1 CD ROM.

[11] Os Bancos de Sementes Comunitários na construção dos territórios de esperança: o caso do assentamento Três Irmãos/PB. 2011. 245 f. Dissertação (Mestrado em Geografia) - Programa de Pôs Graduação em Geografia, Universidade Federal da Paraíba, Joao Pessoa/PB, 2011.

[12] Oliveira, Ariovaldo Umbelino de. Stedile, Joao Pedro. 0 agronegócio X agricultura familiar e a reforma agraria. Brasília: Ed. Concrab, 2004.

[13] Silva, Jose Graziano da. Tecnologia e agricultura familiar. 2 ed. Porto Alegre: Editora da UFRGS, 2003 


\section{Capítulo 9}

Mutirões: O trabalho nos bastidores da Folia de Santos Reis em Pirenópolis, Goiás

\section{Maria Cristina Campos Ribeiro \\ Maria Idelma Vieira D'abadia}

Resumo: 0 artigo enfoca a relação entre trabalho, festa e devoção na Folia de Santos Reis de Pirenópolis Goiás, festa popular com fortes raízes rurais, cujo giro ocorre na cidade desde 1986. Discute-se a relação entre trabalho na forma de ajuda mútua ou mutirões e solidariedade/reciprocidade na concretização da folia, dando-lhe sentido próprio, que se presentifica tornando-a esperada por todos os partícipes com fé e alegria. Abordam-se as práticas que dão sentido a esta folia, nos momentos de preparação, nos giros e pousos e adormecimento ou organização para o próximo ano, tendo como sujeitos, pessoas que assumem papéis distintos de seu cotidiano, mas, relevantes no fazer coletivo que dá sentido ao conjunto da obra que é a folia de Santos Reis.

Palavras-chave: Trabalho, Folia de Santos Reis, Pirenópolis. 


\section{INTRODUÇÃO}

Para elaboração deste trabalho realizou-se pesquisa bibliográfica e de campo. A pesquisa de campo ocorreu na forma de pesquisa participativa onde pesquisadores e pesquisados puderam interagir tanto no âmbito da folia propriamente dita, em seus giros e pousos, quanto no da pesquisa, o que possibilitou a incorporação dos foliões como membros ativos desse processo. Para Brandão a experiência vivida pode enriquecer a investigação: "Como colocar no papel a dramaticidade sem que a passagem do vivido-anotado-pensado-por-mim-para-mim para o escrito-por-mim-paravocês-como-um-texto-científico, não perca a realidade processual, viva e dramática do que li?" (2003, p. 96).

0 artigo inicia-se com algumas reflexões sobre o trabalho coletivo na forma de mutirões ${ }^{12} \mathrm{em}$ Pirenópolis-Goiás, onde essas tradições rurais migraram para a cidade perpetuando-se principalmente nos momentos religiosos e festivos tais como, as folias.

A folia abordada neste trabalho é a 'Folia de Santos Reis urbana de Pirenópolis' cujo giro a que se refere a pesquisa, ocorreu entre os dias 26 e 30 de dezembro de 2016. Para sua realização, os diversos atores desse processo se organizaram em uma rede de trabalhos individuais e coletivos antes, durante e depois da folia, imbuídos pela devoção.

\section{MUTIRÕES EM PIRENÓPOLIS}

Pirenópolis, cidade histórica localizada no interior de Goiás, batizada inicialmente de Minas de Nossa Senhora do Rosário de Meia Ponte, foi um dos muitos núcleos populacionais que se desenvolveram a partir da exploração aurífera em meados do século XVIII na Capitania de Goiás. Meia Ponte, em meados do século XIX, por causa das mudanças nas rotas comerciais e da diminuição dos trabalhos de garimpagem tem sua, economia abalada e a cidade perde parte de seu contingente populacional.

Apesar de longe da capital, a vida se perpetuava, configurando um processo de ruralização com agricultura básica e de subsistência (CURADO; LÔBO, 2011, p. 84). À Medida que as inúmeras necessidades surgiam, o socorro vinha dos vizinhos através de ajuntamentos e mutirões para roçar pasto, plantar, colher, construir casas.

0 mutirão é uma instituição social que ao longo da história, imprimiu à vida rural brasileira uma forma de lidar com as necessidades e os efeitos individualistas da economia latifundiária a partir da ajuda mútua entre vizinhos. Representa um fazer coletivo em que a prerrogativa é a solidariedade e ajuda mútua, o modo pelo qual um grupo desenvolve maneiras de canalizar energias comuns e dedicar o esforço com um senso de determinação moral (TURNER, 2013).

A cerca do trabalho, Antônio Candido (1979), nos fala que toda a relação dos grupos humanos com o seu meio físico e ambiental explica-se pela busca de garantir "os meios de vida". Da correlação entre as necessidades e a sua satisfação é que depende, em boa medida, o equilíbrio social (Candido, 1979, p. 23). E o trabalho é o meio pelo qual homens e mulheres buscam assegurar esses "meios de vida" e deixam suas marcas no espaço

Em Pirenópolis, ainda existem comunidades rurais que se encontram para compartilhar em mutirões festivos, religiosos e de trabalho. A análise das formas de organização do trabalho nos mutirões rurais bem como, de suas representações simbólicas, pode ajudar a compreender como e por qual razão, essa prática se perpetua na cidade, revelando aspectos históricos e sociais dessa solidariedade

Parece que por mágica o mal do mundo se esvai com o ouro que mingua na areia dos rios e no fundo das grupiaras. Não havendo mais aquilo pelo que os homens tornam extremas as relações

120 camponês que necessita de serviço, o solicita e convida os vizinhos, que o socorrem, geralmente para um trabalho de urgência como uma determinada colheita que se pode perder, ou limpar o rego d'agua para que os animais possam bebê-la. 0 mutirão, o adjunto, a troca de dias, a ajuda mútua são termos usados para designar um processo de trabalho calcado na cooperação entre as pessoas, na troca de favores, nos compromissos familiares, diferenciando-se, portanto, das relações capitalistas de compra e venda da força de trabalho (CALDEIRA, Clóvis.1956) 
desiguais e a lógica do interesse. Não havia porque não retornar a um sistema regido por uma suposta solidariedade entre iguais e uma complementaridade cúmplice entre desiguais. (BRANDÃO, 2004, p. 299)

Nesses encontros de trabalho, onde quase sempre, a lida é pesada e exaustiva, o momento festivo, acalenta e traz recordações e memórias que ajudam a aliviar o fardo e consolidar internamente o sentido de pertencimento, que fortalece laços e valores.

"Mutirão! Só esta palavra nos faz ressoar aos ouvidos os alegres rumores dos descantos e folguedos da roça, o estrépito dos sapateados da dança camponesa por entre a zoada dos adufes e violas, nos transporta ao meio das rústicas e singelas cenas de prazer da vida do sertanejo" (GUIMARÃES, 1997, p. 51).

Os trabalhos festivos ambientados no âmbito do Cerrado brasileiro, esse bioma com rica biodiversidade, caracterizado por duas estações, uma seca e outra chuvosa, possibilitam um amplo olhar sob o prisma das diversas formas de representações que caracterizam as religiosidades e que passam a qualificar os espaços.

Em Pirenópolis também, ciclos festivos se articulam com o tempo de plantar e colher e com o tempo-lugar do cerrado onde chuva e estio vão reunindo pessoas em torno do trabalho, e celebração ora festiva, ora religiosa, ora tudo junto.

As Festas do Divino Espírito Santo são associadas a antiquíssimos festejos realizados em épocas de colheita, como instrumentos de coleta e distribuição de víveres e donativos em épocas de "fomes apertadas" (TORRES, 1856)13. Como já observado, são festas fundadas na reciprocidade e na solidariedade, baseadas em relações de parentesco e vizinhança, que se organizam em grandes mutirões. (IPHAN, 2008, p. 13).

As festas populares fazem parte do contexto urbano e rural do município de Pirenópolis, tendo um calendário e ritmo próprio. É um todo organizado que se repete ano após ano. Essas festas são preparadas, esperadas e também recordadas. As lembranças dos tempos passados, o elo que liga um tempo longínquo com o momento atual constrói a memória coletiva de um lugar. A temporalidade traz à tona a experiência do enigma da identidade e da diferença, da permanência do mesmo, através da vivência, da mudança.

Nos momentos festivos, os partícipes se irmanam e adentram um tempo e espaço próprio, ritualizado, onde roupas, comidas e adereços, dão novo sentido à vida, envolvendo-os nos festejos de diferentes formas, pois conforme Lobo e Maia (2011, p. 150), "fazer-se presente na festa é estar envolvido de diferentes maneiras emocionalmente através das ações ritualísticas com dimensões social e simbólica que dão sentido à realidade, à vida e imaginário das pessoas ligadas aos festejos"

Para Halbwachs (2004, p. 33), a memória individual, é um aspecto da memória coletiva e nas folias os saberes transmitidos oralmente representam um exercício de recordar, ora expressando vínculos com lugares, ora ressignificando vivências internalizadas:

"Transplantada para a cidade, a folia se reinventa e se reatualiza conforme seu novo espaço,espaço esse marcado por conflitos, estranhamento, preconceitos e individualismo em oposição aos valores cultivados no meio rural onde se valoriza o coletivo a sociabilidade a comunhão, o companheirismo, a ajuda mutua, entre outros" (D'ABADIA, BATISTA, 2012, p.03).

\section{FOLIA DE SANTOS REIS EM PIRENÓPOLIS, GOIÁS}

A Folia de Santos Reis, manifestação do catolicismo popular, representa a história bíblica da natividade onde os reis Baltazar, Melquior e Gaspar percorreram logo trajeto para visitar o recém nascido, menino Jesus. Esses reis são homenageados no dia seis de janeiro, e através da folia se revive a visita dos magos.

13 TORRES, J., Fastos Açorianos. In: Panorama, 1856. 
Com herança cultural de origem européia, permeada de rituais festivos e religiosos, a folia de reis adquiriu características próprias em cada região. Em Pirenópolis, as Folias de Santos Reis são compostas de pequenos grupos de foliões

Esta manifestação cultural é representativa da vida social, não sendo possível precisar o início dos giros pelo município surgido da mineração do ouro. Contudo, a persistência dessa tradição sobre o tempo é resultante dos ensinamentos passados de geração para geração, da influência das migrações e do entendimento daqueles que lideram a peregrinação - alferes ou embaixador. (LOBO, 2016, p. 03)

A partir da década de 1980, essas festas que eram eminentemente rurais, passaram a compor o quadro das festividades urbanas, em decorrência do movimento migratório das pessoas do campo para as periferias da cidade e em 1986, os foliões Israel Coelho, Geraldo Vicente dos Santos (Dedé) e Mário Vicente dos Santos, criaram a Folia de Santos Reis de Pirenópolis, que gira entre os dias 26 e 30 de dezembro. Tudo o que se arrecada, é doado ao Asilo São Vicente de Paula, localizado no centro de Pirenópolis, no último pouso e entrega da bandeira, que ocorre no asilo.

A Folia de Santos Reis de Pirenópolis, 'Folia de Reis da Rua' ou 'Folia do Mário', nome dado em homenagem ao folião-guia e alferes que a organiza,gira os bairros da cidade principalmente do Carmo, Bonfim e Lapa. É composta por foliões deste e de outros municípios, que se estabelecem na cidade pelo período de duração da folia, composta pela sequencia ritualística do "junta, o levantamento da bandeira, a entrega das guias, a farta mesada de comidas, as cantorias de saudação aos Reis Santos, o peditório de esmolas, o giro até as casas dos devotos e entrega dos donativos" (D'ABADIA, LOBO, 2016, p. 06).

Firma-se um compromisso entre padroeiros (os três reis santos), os agentes e os devotos, onde cada um tem seu atributo próprio. Os Santos Reis oferecem bênçãos e proteção, os agentes, ou todos os que atuam diretamente na realização da folia, se dedicam integralmente aos serviços em honra ao padroeiro e os devotos ou moradores que participam da folia e tem fé nos reis santos, se comprometem com a fé e retribuição através de donativos. (PESSOA, 2007, p 193-194).

A Folia de Reis urbana de Pirenópolis traz o sentido da viagem através do giro, num trajeto com começo, meio e fim que em 2016, percorreu os bairros do Bonfim, Lapa, Carmo e zona rural próxima. Segundo o alferes, as bandeiras não podem cruzar-se ou percorrer o caminho da outra. Considera-se o giro, um caminho circular,porque não se pode retornar ou voltar no trajeto. Porém não se nota o desenho do círculo, o que constitui segundo Rosendahl (2010), uma geografia própria, consolidando espaço sagrado, de manifestação cultural atrelado a processos sociais com significados simbólicos.

Os foliões caminham, durante o dia, pelas ruas no percurso previamente traçado até o local do pouso, adentrando as casas em que há consentimento e convite para a entrada da bandeira. Formam-se dois grupos, cada um composto por uma bandeira de Reis, um embaixador guia e contra guia, dois músicos fazendo a segunda voz ${ }^{14}$, demais músicos, foliões e um palhaço. Às famílias visitadas pela bandeira, solicitou-se a doação de alimentos para o Asilo São Vicente de Paula, localizado no centro da cidade de Pirenópolis, onde serão entregues os donativos arrecadados no giro.

Os pousos, realizados a noite são repletos de rituais, iniciando-se com a chegada e cantoria que apresenta as bandeiras diante de um arco ornado com flores e posicionado na entrada da casa. Devem achar o presente-pinga, rezam no altar e agradecer a mesa. Depois do jantar, dançam catira e finalmente se despedem para que no dia seguinte voltem ao local onde darão continuidade ao giro.

\section{4- 0 TRABALHO NA FOLIA}

Encontram-se para esta folia, pessoas de diferentes localidades, unidas pelo forte vínculo desta tradição ressignificada, que a maioria recorda, de tempos vividos na zona rural, onde, pelo menos

${ }^{14}$ Respectivamente do guia e contra guia (nota do autor). 
os mais velhos, seus pais e avós, se reuniam para compartilhar em mutirões festivos, religiosos e de trabalho.

Na Folia da Rua, em Pirenópolis Goiás realizada em 2016, a preparação e organização mais efetiva começou cerca de quatro meses antes do ajuntamento dos foliões para a folia propriamente dita, com encontros de trabalho e preparativos, prevalecendo a ajuda mútua como nos mutirões rurais. Segundo Mauss (2013), nessa forma de trabalho, prevalece a reciprocidade, onde dar, receber e retribuir ocorrem a partir da constatação de que as modalidades de trocas nas sociedades arcaicas não são apenas coisas do passado, tendo importância fundamental para se compreender a sociedade moderna. Cada uma dessas obrigações cria um laço e vínculo que fortalece os sujeitos em sua fé, individualidade e ação coletiva, dando sentido à existência desta folia desde 1986.

Nas Folias existe uma hierarquia com funções que devem ser cumpridas pelos partícipes, funções estas que podem ser alteradas conforme a necessidade. Por exemplo, um músico pode deixar de assumir o papel de embaixador por estar cansado podendo outra pessoa, assumir esse papel.

A tabela abaixo relaciona algumas funções desempenhadas na Folia de Reis de Pirenópolis em 2016 e revela a interdependência de todas elas. Nota-se também que a maioria das funções necessita de mais de uma pessoa para desempenhá-la pois precisa suprir as duas bandeiras, que caminham em sentidos diferentes, ao mesmo tempo, encontrando-se no retorno ao pouso, no final da tarde.

\begin{tabular}{|c|c|c|}
\hline $\begin{array}{l}\text { Atores ou } \\
\text { Sujeitos }\end{array}$ & $\begin{array}{l}\text { Quantidade } \\
\text { de pessoas } \\
\text { por função }\end{array}$ & Função \\
\hline Alferes & 01 & $\begin{array}{l}\text { São responsáveis diretos pela organização dos rituais, definições dos locais dos } \\
\text { pousosdatas, demais orientações e rota circular traçada (constituída pelas casas onde } \\
\text { os pousos acontecerão). Cuida da escolha dos grupos que serão convidados para } \\
\text { tocar, cantar e girar a folia, articular e arrecadar donativos para bancar a estadia dos } \\
\text { foliões e local onde serão acolhidos para dormir e se instalar durante a folia, } \\
\text { geralmente com barracas. Promove a entrega dasas guias, broche formado por uma } \\
\text { fita e, às vezes, uma medalha dos Reis Santos, acompanhados do crachá que indica o } \\
\text { cargo ocupado pelo folião durante os rituais. Além disso cuida de eventualidades } \\
\text { surgidas no decorrer da folia. }\end{array}$ \\
\hline Regentes & 02 & $\begin{array}{l}\text { auxiliam os alferes, coordenando o giro e os pousos, para que o ritual seja cumprido e } \\
\text { o junta } \\
\text { auxiliar o alferes na entrega entregues as guias, broche formado por uma fita e, às } \\
\text { vezes, uma medalha dos Reis Santos, acompanhados do crachá que indica o cargo } \\
\text { ocupado pelo folião durante os rituais }\end{array}$ \\
\hline $\begin{array}{c}\text { Alferes da } \\
\text { bandeira }\end{array}$ & 02 & $\begin{array}{l}\text { Cuidam das bandeiras e geralmente as conduzem durante a folia. Geralmente } \\
\text { guardam a bandeira de um ano para o outro. }\end{array}$ \\
\hline $\begin{array}{l}\text { Embaixadores } \\
\text { da folia: Guia e } \\
\text { Contra guia }\end{array}$ & 04 & $\begin{array}{l}\text { São os músicos responsáveis por ter, na memória, a pauta da história que conduz a } \\
\text { folia pelo seu giro. São os responsáveis por relacionarem dois mundos: o momento } \\
\text { real e a história mítica dos Reis em viagem. Os Guias fazem a primeira voze conduzem } \\
\text { o fio do enredo do ritual, os Contra guias: respondem ao verso cantado pelo guia } \\
\text { complementando a ideia apresentada. }\end{array}$ \\
\hline $\begin{array}{l}\text { Foliões } \\
\text { cantores da } 2^{\text {a }} \\
\text { voz }\end{array}$ & 04 & São os músicos responsáveis por entoar a segunda voz dos guias e contra guias ${ }^{15}$. \\
\hline $\begin{array}{l}\text { Foliões } \\
\text { músicos }\end{array}$ & $\begin{array}{l}\text { Quantidade } \\
\text { indefinida }\end{array}$ & $\begin{array}{l}\text { São responsáveis por tocar e cantar nos diversos momentos rituais da folia. Preparam } \\
\text { e decoram seus instrumentos (com medalhinhas, fitas, chocalho de cascavel). }\end{array}$ \\
\hline $\begin{array}{l}\text { Foliões que } \\
\text { acompanham a } \\
\text { folia }\end{array}$ & $\begin{array}{l}\text { Quantidade } \\
\text { indefinida }\end{array}$ & $\begin{array}{l}\text { Os foliões, em sua maioria, são oriundos de outras regiões, apesar do organizador - o } \\
\text { alferes - morar em Pirenópolis. }\end{array}$ \\
\hline Palhaços & 02 & $\begin{array}{l}\text { São responsáveis por afastar os maus espíritosna folia. Preparam sua indumentária, } \\
\text { máscara e cajado para acompanhar os foliões nos giros,marcando o compasso das } \\
\text { músicas. Fazem ainda, brincadeiras para alegrar as crianças e recebem os donativos } \\
\text { ofertados depois que a folia se retira da casa que recebeu a bandeira. }\end{array}$ \\
\hline Procuradores & 02 & $\begin{array}{l}\text { Cuidam da organização das filas para a distribuição da comida e demandas de } \\
\text { organização geral durante a folia no giro e pousos. }\end{array}$ \\
\hline Salveiros & $\begin{array}{l}\text { Quantidade } \\
\text { indefinida }\end{array}$ & Anunciam o início dos rituais, estourando os fogos de artifício. \\
\hline Devotos & $\begin{array}{l}\text { Quantidade } \\
\text { indefinida }\end{array}$ & $\begin{array}{l}\text { Há os devotos que recebem a folia em sua casa }{ }^{16} \text { ofertando o pouso e recebendo a folia } \\
\text { no outro dia, quando oferecerão o almoço. A comida é servida para foliões e } \\
\text { comunidade. }\end{array}$ \\
\hline
\end{tabular}

${ }^{15}$ embora tenham repertório e vocabulário internalizado, na maioria das vezes improvisam, tendo em vista as peculiaridades do que vão encontrar em cada casa (nota do autor).

${ }^{16} 0$ direito do pouso é cedido para alguém que precisa cumprir voto com os Santos Reis, pagar promessa ou manter uma tradição familiar. 
Os ajuntamentos de trabalho podem ocorrer antes, durante e depois da folia, conforme a necessidade, mas os foliões se comunicam entre um ano e outro com bastante frequência pois participam de diversas folias, Em cada etapa há diferenciação de funções, desdobramentos e organização de grupos de trabalho conforme as demandas.

No período que antecede à folia, segundo os foliões entrevistados, há muito que organizar para estarem de corpo e alma neste momento de devoção, onde reencontram companheiros e vivificam sua fé. Desde cuidar da família e da casa para que tudo corra bem em sua ausência, até questões como, preparar os instrumentos, encordoá-los, cuidar da indumentária. Há também, segundo eles, um trabalho interno, para honrarem a missão espiritual a cumprir, a devoção aos Santos Reis, corporificada na Folia de Reis.

Também os devotos que oferecem pouso tem muito a fazer, enfeitando suas casas para receberem a folia, preparando o arco, altar e presépio, bem como, toda a logística da comida, servida com fartura. Para isso buscam ajuda dos familiares, vizinhos e amigos, sendo que algumas funções são geralmente desempenhadas por pessoas que tem mais prática em realizá-las, como é o caso da senhora que decorou alguns altares e arcos, fazendo-o com freqüência em folias e rezas.

Depois da folia,o trabalho tem continuidade, por meio dos encontros entre os foliões em lugares de seu cotidiano, para combinar as próximas folias, pois uns ajudam os outros a tecer essa rede de devoção e festa onde prevalece a reciprocidade (Mauss, 2013). Além disso, o alferes da bandeira, cuida das duas bandeiras, guardando-as até o próximo ano. Contudo, em 2016 a bandeira ficou aos cuidados da senhora que dará o primeiro pouso em dezembro de 2017.

\section{CONSIDERAÇÕES FINAIS: TRABALHO, FESTA, E DEVOÇÃO}

Graças à festa, o passado para sempre perdido, retorna de algum modo ao presente, por ocasião da celebração festiva da memória, entendida como reminiscência desencadeada pela identificação e pelo reconhecimento coletivo das suas marcas.

Lugar não é apenas onde algo está situado; o próprio lugar incorpora significado, que depende da história pessoal que uma pessoa traz para ele. É através dessas interações pessoas-lugar que desenvolvemos uma profunda associação psicológica com um lugar específico, seja ele lar, rua, cidade, zona rural, estado, região ou nação (CARNEY, 2007, p.128)

Os ajuntamentos de trabalho na forma de ajuda mútua mediatizam festa e devoção na Folia de Reis de Pirenópolis. As festas podem ser vistas, como gestos simbólicos (BRANDÃ0, 2008, p. 49) que atraem a colaboração dos vizinhos, parentes e amigos, para concretizar tudo que se insere em seu contexto, a comida, bebidas, música, catira, rezas. Esses gestos são evidenciados em práticas diversas, desde a organização da indumentária, dos giros, da música, pousos, recepção e hospedagem dos foliões, acolhida nas diversas casas, preparação das comidas nos pousos até a entrega da bandeira, das esmolas recolhidas, despedida dos foliões e guarda da bandeira para o próximo ano. Nesta perspectiva, o trabalho assume significados múltiplos para os participantes, que vão desde o sentido penitencial até a perspectiva de lazer e festa.

Saber dar, doar bens, trabalho, afeto, sentido, saber receber e saber retribuir. Fazer desta alternância de recíprocas intertrocas que resistem ao mundo dos negócios em nome do mundo da vida, a própria Essência solidária da razão de ser e de viver. E mais do que esta razão, a de saber dar-se aos outros, aprender a "sair-desi" e abrir-se aos outros. Reaprender a reciprocidade na convivência de uma vida menos competitiva e mais compartilhada. Uma vida que afinal valha a pena ser vivida (BRANDÃO, 2008, p. 52).

Esse labor repleto de significados promove a integração entre os partícipes dessa rede devocional e festiva que é a folia e possibilita reafirmar valores no grupo, a integração entre as pessoas e com tudo que os circunda, além de fortalecer vínculos e o sentimento de pertencimento. 


\section{REFERÊNCIAS}

[1] BRANDÃO, Carlos R.A pergunta a várias mãos: a experiência da pesquisa no trabalho do educador. São Paulo: Cortez, 2003.

[2] _ De tão longe eu venho vindo: símbolos, gestos e rituais do catolicismo popular em Goiás. Goiânia: Ed. UFG, 2004.

[3] Escola/SEED/MEC Brasília, 2008.

Festas de Trabalho. I: Cultura Popular e Educação: Salto para o Futuro. TV

[4] CANDIDO, Antônio. Parceiros do Rio Bonito. 11 ed, Rio de Janeiro: Ouro sobre azul, 1979.

[5] CALDEIRA, Clóvis. Mutirão, formas de ajuda mútua no meio rural. São Paulo: Brasiliana,1956.

[6] CARNEY, George O. Música e Lugar. In: CORREA, Roberto Lobato; ROSENDAHL, Zeny (Orgs.). Literatura, Música e Espaço. Rio de Janeiro: EdUERJ, 2007.

[7] CURADO, João Guilherme da Trindade; LÔBO, Tereza Caroline. Festas do Catolicismo Popular: Expressões Identitárias Presentes em Pirenópolis-Goiás. In: Ciberteologia - Revista de Teologia \& Cultura. Ano VII, no 35, p. 82-92, 2011.

[8] D’ABADIA, M. I. V. e BATISTA, O. Idas e vindas nos giros das folias: elos que unem religiosidade, cultura popular e sociabilidade. GO: Anais do III Congresso Internacional de História da UFG, 2012.

[9] GUIMARÃES, Bernardo. O Seminarista. 23 ed. São Paulo, Ática, 1997.

[10] HALBWACHS, Maurice. A memória Coletiva. São Paulo: Centauro, 2004.

[11] IPHAN. Dossiê: Festa do Divino Espírito Santo de Pirenópolis - GO. Goiás, 2008.

[12] D’Abadia, M. I. V., LOBO, T. C. As Folias de Santos Reis: manifestação religiosa cristã no cerrado goiano. II Simpósio Internacional da ABHR, 2016, p. 06.

[13] LOBO, A. S.Sons e movimentos: Sentidos do sagrado na musicalidade da Folia de Santos Reis de Pirenópolis. Goiás. Dissertação, UEG, 2016.

[14] LOBO, T. C. e MAIA, C. E. S. Diferentes formas de estar na festa. Textos escolhidos de cultura e arte populares, RJ, vol. 8, no 1, p.149-160, mai. 2011.

[15] MAUSS, M. Ensaio sobre a dádiva. São Paulo: Cosacnaify Portátil, 2013.

[16] PESSOA, Jadir de Morais; FÉLIX, Madeleine. As Viagens dos Reis Magos. Goiânia: Editora da UCG, 2007.

[17] ROSENDAHL, Zeny. Trilhas do Sagrado. Rio de Janeiro: EDUERJ, 2010.

[18] TURNER, V. W. O processo ritual: estrutura e antiestrutura. Petrópolis, RJ: Vozes, 2013.

[19] SANTOS, Mário Vicente dos. Mário Vicente dos Santos: depoimento [dez. 2016]. Entrevistadora: Maria Cristina Campos Ribeiro. Pirenópolis, 2016. MP3.

[20] SANTOS, Mário Vicente dos. Mário Vicente dos Santos: depoimento [maio. 2017]. Entrevistadora: Maria Cristina Campos Ribeiro. Pirenópolis, 2017. MP3. 


\section{Capítulo 10}

Produção agropecuária e as políticas públicas na comunidade rural de remanescentes Quilombolas, Marinheiro, em Piripiri-PI

\section{Silvana Araújo Maciel}

Raimundo Wilson Pereira dos Santos

Resumo: No Brasil, após séculos de luta por direitos e igualdade, os negros ainda convivem com a falta de desenvolvimento de políticas públicas de ação afirmativa voltadas para a diminuição das desigualdades raciais, criação de infraestrutura e equipamentos sociais para o desenvolvimento produtivo e a conquista da autonomia econômica. Diante dessa realidade este trabalho teve como objetivo geral: "analisar as políticas públicas de incentivos à produção agropecuária na comunidade de remanescentes quilombolas", tema pertinente para a discussão no âmbito da ciência geográfica. Utilizou-se na metodologia a pesquisa bibliográfica em livros e na internet, assim como a pesquisa de campo com aplicação de questionários semiestruturados com 16 famílias da comunidade e entrevistas com o representante da Associação dos Trabalhadores Rurais Quilombolas da Comunidade Marinheiro e do Sindicato Rural de Piripiri, Piauí. Através da pesquisa constatou-se que $81 \%$ da produção agrícola é destinada para subsistência das famílias, enquanto que na pecuária, apenas 19\% é comercializado na cidade vizinha de Capitão de Campos, Piauí. Os únicos programas de auxílios as atividades agropecuárias presentes na comunidade são o Programa de Microfinança Rural do Banco do Nordeste - Agroamigo, e o Programa Nacional de Fortalecimento da Agricultura Familiar - PRONAF, considerados de difícil acesso pelas famílias e insuficientes para garantir a subsistência das mesmas. A pesquisa permitiu percebermos a necessidade de regularização das terras do Marinheiro pelo Instituto Nacional de Colonização e Reforma Agrária - INCRA, pois acreditamos que assim as Políticas Públicas advindas do programa Brasil Quilombola do Governo Federal contribuiriam trazendo maiores benefícios e assistência para essa comunidade.

Palavras-Chave: Quilombolas. Políticas públicas. Agropecuária. 


\section{INTRODUÇÃO}

A resistência negra no Brasil se manifestou sobretudo na fuga de escravizados para as florestas do sertão nordestino. Fato este que culminou no surgimento dos denominados quilombos, lugares onde abrigava os escravos refugiados, cujo principal objetivo era assegura a liberdade dos fugitivos.

As comunidades remanescentes de antigos quilombos também são conhecidas como "mocambos", "comunidades negras rurais", quilombos contemporâneos", comunidades quilombola" ou "terras de preto", e muitas destas comunidades conseguiram manter as tradições que seus antepassados trouxeram da África (ANJOS, 2001).

De acordo com o mito da democracia racial a discussão sobre a questão racial no Brasil não tem mais sentido, visto que não há escravidão no Brasil e a população vive em uma democracia, onde todos têm acesso a saúde, educação, lazer etc., entretanto os indicadores sociais revelam desigualdades sociais e a falta de políticas públicas no conjunto da população negra no Brasil.

De acordo com Souza (2012, p.118) "após o desenvolvimento de pesquisas que privilegiam as condições de vida de negros e pobres no Brasil, [...] apontam a população negra como a mais vulnerável ao desemprego, ao analfabetismo, a dificuldades de acesso à moradia, saúde e educação". As comunidades remanescentes de quilombos têm a terra como um organismo para pensar o grupo e não como meio de dependência.

\section{OBJETIVOS}

\subsection{GERAL}

"Analisar as políticas públicas de incentivos à produção agropecuária na comunidade de remanescentes quilombolas", tema pertinente para a discussão no âmbito da ciência geográfica.

\subsection{ESPECÍFICOS}

- Resgatar brevemente a participação do negro na expansão da economia brasileira, destacando suas lutas e resistências;

- Caracterizar as práticas agrícolas e de pecuária desenvolvidas na comunidade foco da pesquisa;

- Verificar a existência de políticas públicas na comunidade, observando os possíveis benefícios adquiridos pelas famílias com as mesmas.

\section{NEGRO NA EXPANSÃO DA AGRICULTURA BRASILEIRA}

É inegável o papel da agricultura na mudança da relação, homem e natureza, sendo notável a expansão ao longo dos séculos do controle do primeiro sobre o segundo. A relação que o homem mantém com a natureza, nem sempre foi harmônica, e a Geografia estuda essa relação. Mendonça (2011) destaca que por ser a Geografia uma ciência de relações, esta analisa a relação em questão e a relação da geografia com outras ciências, ressalta ainda que a Geografia se propõe a ser uma ciência ponte entre os aspectos naturais e os aspectos humanos do planeta.

O processo de evolução da agricultura, assim como as mudanças na relação homem e natureza, ocorreu de modo lento e gradual, graças as sucessivas transformações que afetaram as sociedades humanas, de diferentes maneiras e em diferentes lugares. Santilli $(2009$, p. 36) destaca que "o desenvolvimento de novos sistemas agrícolas esteve associado a mudanças ambientais, sociais, econômicas e culturais.

No Brasil, estudos arqueológicos comprovam que os povos que habitaram o território, antes da chegada dos colonizadores europeus, já praticavam a agricultura, de modo incipiente, em conjunto com as tradicionais atividades de caça e coleta de frutos na floresta.

Sobre a agricultura o Brasil, Santilli (2009, p. 36) reforça que esses povos desenvolveram sistemas agrícolas tradicionais, representados por uma enorme variedade de saberes e práticas agrícolas. A autora destaca ainda, que mesmo com o rico patrimônio biológico e cultural brasileiro, o modelo 
agrícola adotado pelos portugueses era baseado no cultivo de apenas um gênero agrícola que tinha como destino a exportação, assim como no latifúndio e na escravidão forçada dos povos indígenas e negros trazidos da África.

A partir do século XVI, o plantio da cana-de-açúcar foi produzido em diferentes localidades, mas de acordo com Mattos (2012, p. 104) "foi nas capitanias de Pernambuco e da Bahia que esse produto melhor se adaptou, por conta das condições geográficas e do desenvolvimento da colonização".

A colonização portuguesa e a divisão do território brasileiro em grandes lotes de terras, denominados sesmarias, as quais foram distribuídas a donatários que receberam a missão de administrá-las, deu origem, de acordo com Dantas, França e Medeiros (2011, p. 40), a "célula básica da reprodução colonial".

Os escravos trazidos para o Brasil ajudaram no desenvolvimento dos engenhos, minas, plantações, fábricas, cozinhas e salões, além de ter marcado aspectos da cultura material e espiritual do país. De acordo com Mattos (2012, p. 104) "os africanos começaram a ser empregados por volta do século XVII, quando o tráfico atlântico de escravos havia se consolidado, fazendo então, do africano a peça fundamental da empresa açucareira".

O negro teve uma participação expressiva na agricultura desde a sua chegada no país, este foi utilizado como mão-de-obra na cultura da cana-de-açúcar, foi obrigado a executar todas as etapas do processo, desde o plantio, colheita e produção nos engenhos. Sob pena de sofrerem castigos e violências em caso de desobediência ou fugas.

\section{1 A RESISTÊNCIA NEGRA E AFIRMAÇÃO NA SOCIEDADE BRASILEIRA}

Uma das marcas da escravidão foi a resistência do negro a sua condição de escravizado, em muitos casos havia negociações com os senhores por maior autonomia em outros acabavam se rebelando, de maneira coletiva ou individual, organizando fugas e revoltas. Sobre as fugas de escravos no Brasil Reis e Gomes (2012, p. 10) relata que era "a fuga que levava a formação de grupos de escravos fugidos, aos quais frequentemente se associavam outras personagens sociais"

A situação de opressão dos escravos levou na segunda metade do século XIX a uma forte atuação do movimento abolicionista e se sucederam uma serie de revoltas e fugas para os quilombos. A medida que estes surgiam, cada vez em maior número e diferentes locais, por iniciativa dos proprietários, aumentava a repressão, na figura dos capitães do mato ou agregados que eram contratados para capturar os fugitivos, ou ainda por iniciativa do Governo, através das expedições militares e lei severas (MATTOS, 2012)

Tais expedições, muitas das vezes, possuíam objetivos que iam além da captura does escravos. De acordo com Varela (2006) a manutenção da posse das terras nos quilombos, fez parte dos conflitos no campo brasileiro, tendo em vista que tais terras eram doadas em forma de prêmios a quem destruíssem os quilombos.

É importante lembrar que a estrutura agrária brasileira, definida pelos colonizadores e que procurou atender os interesses do mercado europeu, contribuiu no atual cenário da distribuição desigual da terra no país. Tal cenário se consolidou com a implementação da Lei de Terras, em 1850, que surge como um instrumento de consolidação da grande propriedade rural através da legitimação das posses das terras devolutas, tendo na compra a única forma de aquisição. Ianni (1984, p. 175) destaca que a Lei de 1850 "extingue o princípio de doação e inaugura o da compra, para aquisição de terras devolutas. Tratava-se de dificultar o acesso à terra, por parte de exescravos, camaradas, imigrantes, colonos, moradores e outros".

0 acesso à terra tem demonstrado demandas históricas no que se refere ao trabalho e a sobrevivência através das diferentes formas de uso da terra e os recursos do território. Medeiros (1989, p.138) afirma que "no início dos anos 80, a luta pela terra na sua forma recorrente em diversos momentos da história do país, ou seja, envolvendo posseiros e grileiros, rendeiros, foreiros ou parceiros e proprietários de terra [...] se intensificou".

Sobre o território e a definição desse conceito chave da Geografia Raffestin (1993) afirma que o território é uma construção conceitual a partir da noção de espaço, ao se apropriar de um espaço o ator territorializa o espaço. Nessa abordagem o território seria produzido por uma variedade de relações que o indivíduo ou grupo de indivíduos matem entre si e com a natureza. 
Enquanto Souza (2003) afirma que o território é "um espaço definido e delimitado por a partir de relações de poder". Destaca que o estudo das ligações afetivas e de identidade entre um grupo social e o espaço habitado são cruciais na compreensão da gênese de um território.

Nos territórios remanescentes os negros podem reafirmar seus valores e costume africanos ou afro-brasileiros, reinventando a sua identidade cotidianamente, além de fundamentar sua luta em referências ancestrais e simbólicas.

0 reconhecimento da luta das comunidades negras rurais, oriundas dos antigos quilombos, aparece com as mudanças político-institucionais e administrativas assinaladas pela Constituição de 1988, a qual regulamenta que, "aos remanescentes das comunidades dos quilombos que estejam ocupando suas terras é reconhecida a propriedade definitiva, devendo o Estado emitir-lhes os títulos respectivos (BRASIL, 1988, Art. 68). O artigo 68 garantiu o direito à moradia e manutenção dos costumes e tradições. Entretanto foi através do decreto presidencial 4.887/2003 que os procedimentos de identificação, reconhecimento, delimitação e titulação das terras ocupadas foram regulamentados.

\section{METODOLOGIA}

De acordo com dados da CPRM (2004) o município de Piripiri está localizado na microrregião do Baixo Parnaíba Piauiense e possui uma área irregular de $1.302 \mathrm{~km}^{2}$, a sede do município tem as

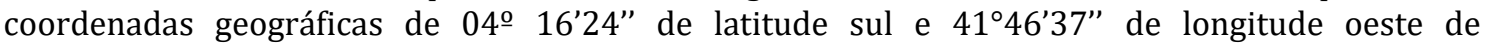
Greeenwich, sendo distante da capital do estado do Piauí, Teresina, cerca de $157 \mathrm{~km}$. De acordo com dados do último censo do IBGE (2010) a população do município de piripiri era de 61.834 pessoas. A comunidade Marinheiro localiza-se a $36 \mathrm{~km}$ do município de Piripiri, Piauí, zona rural. Possui aproximadamente 45 famílias de remanescentes quilombolas.

Mapa 1 - Localização da Comunidade Remanescente de Quilombo, Marinheiro.

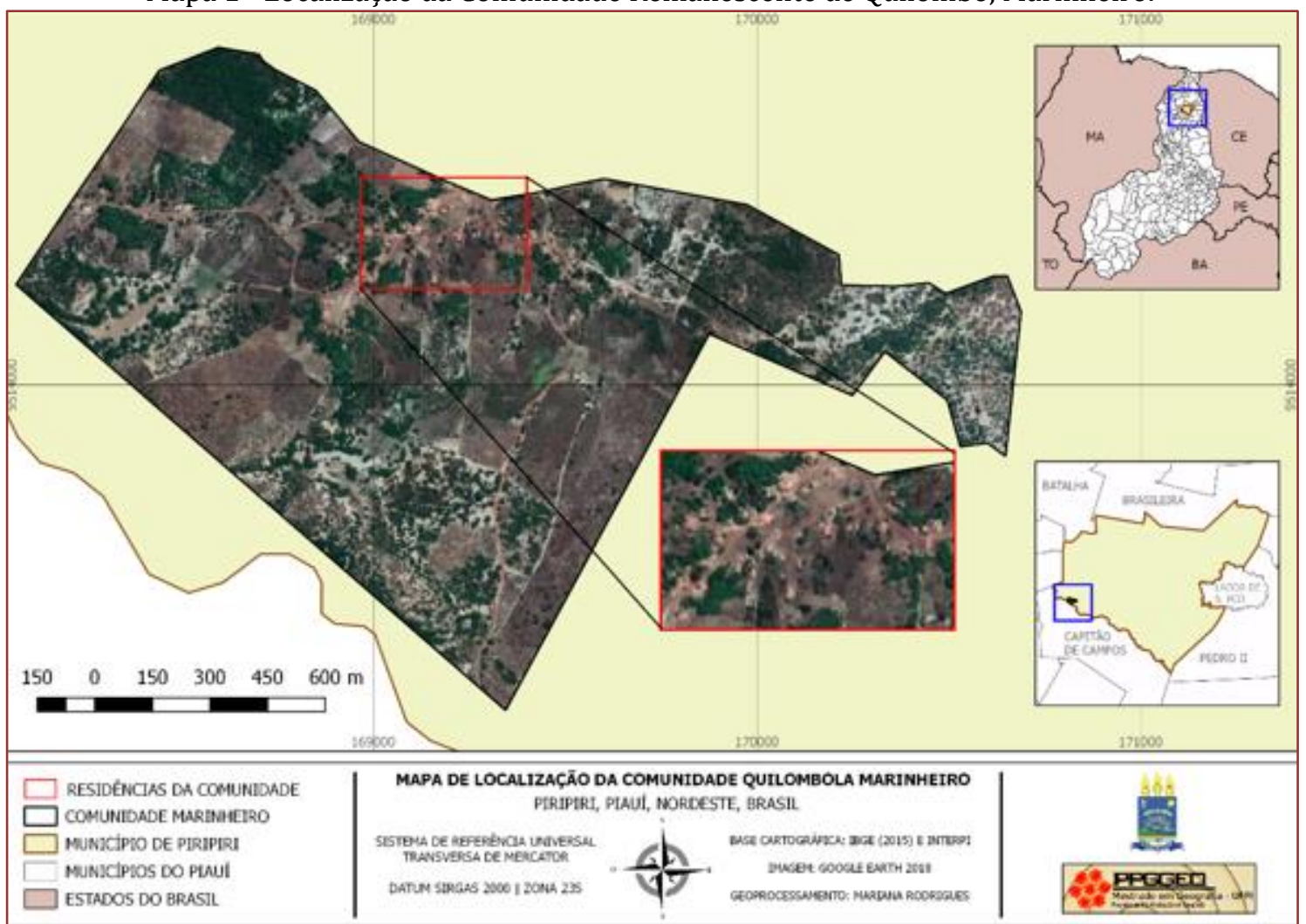

Banco de dados: IBGE (2010); Organização: Silvana Maciel. Geoprocessamento: Mariana Rodrigues

Para construção do artigo, inicialmente realizamos uma pesquisa bibliográfica em livros (impressos e digitais), analisamos a Constituição da República de 1988, e buscamos informações, pertinentes a 
pesquisa, no site do Instituto Brasileiro de Geografia e Estatística - IBGE. Tais pesquisas possibilitaram um melhor entendimento sobre a participação social e econômica do negro no Brasil, assim como suas lutas por direitos e afirmação na sociedade.

Realizamos também uma pesquisa de campo na comunidade, onde aplicamos questionários com 16 famílias, selecionadas de forma aleatória. Nessa fase contamos com a ajuda de um morador quilombola que nos apresentou as famílias, estas por sua vez se mostraram bastante receptivas e não se opuseram a responder os questionários.

Afim de obter maior consistência dos dados, nessa fase da pesquisa, entrevistamos o representante da Associação dos Trabalhadores Rurais Quilombolas e o representante do Sindicato dos Trabalhadores Rurais de Piripiri, Piauí. Fato que possibilitou, sistematizar e organizar melhor os resultados da pesquisa em forma de gráficos, além de enriquecer as análises e discussões sobre a temática em questão

\section{RESULTADOS}

A análise dos dados coletados em campo, com as 16 famílias da comunidade foi permitiu conhecer melhor as principais atividades de agricultura e pecuária que lá são desenvolvidas, bem como as políticas públicas governamentais para o desenvolvimento de tais atividades.

Sobre as características da renda familiar, observamos que (69\%) da população pesquisada receber entre 1 e 2 salários mínimos por mês, demonstrando um elevado número de casais aposentados na comunidade.

Quando pesquisamos sobre os benefícios sociais que as famílias recebem do Governo Federal, percebemos que $60 \%$ recebem o bolsa família, sendo que em alguns casos, este se apresenta como a única renda fixa da família. Apenas duas famílias possuem membros que trabalham fora da comunidade, os quais utilizaram como justificativa a falta de oportunidade que existe na própria comunidade.

Ao direcionarmos a pesquisa para as principais atividades de agricultura desenvolvidas na comunidade pelas famílias constatamos que os produtos mais cultivados são o arroz (22\%), feijão (22\%) e milho (22\%), (gráfico 1), os quais são utilizados, principalmente para a subsidência. Apenas $19 \%$ afirmaram que os produtos cultivados são comercializados na cidade vizinha, distante 8 km, Capitão de Campos, Piauí e 81\% para consumo próprio.

Gráfico 1 - Principais gêneros agrícolas cultivados

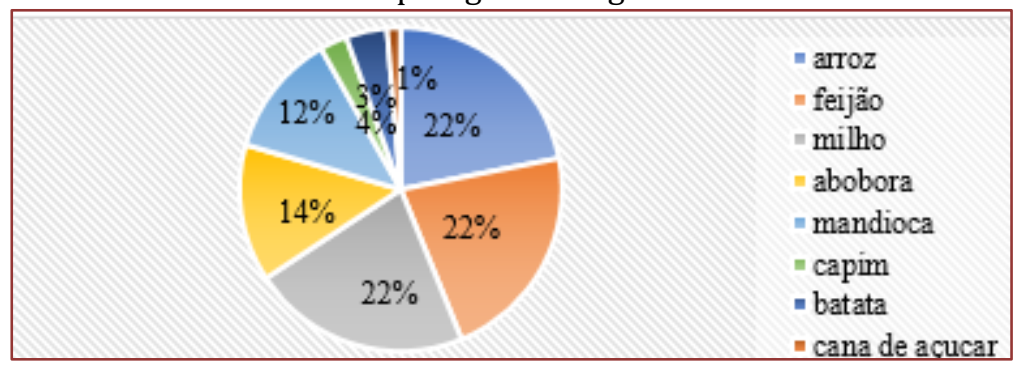

Fonte: Maciel, 2018.

A atividade de pecuária desenvolvidas pelas famílias são bastante variadas, entretanto algumas se destacaram (gráfico 2); 52\% possuem como principais rebanhos os caprinos, 32\% suínos e 16\% gado. Os rebanhos são destinados em sua maioria para a subsistência das famílias, apenas 19\%, entre gado e caprino, são comercializados nas proximidades da comunidade, servindo de renda complementar para as famílias, pois segundo os moradores apenas o lucro de tal comercialização não é suficiente para o sustento familiar. 
Gráfico 3 - Principais rebanhos existentes na comunidade

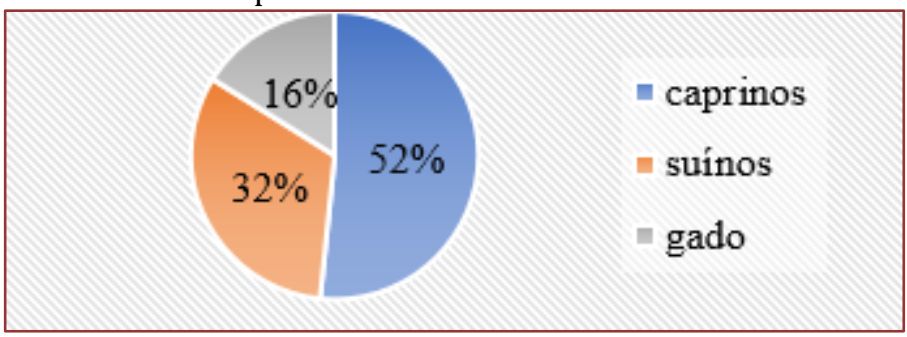

Fonte: Maciel, 2018.

Quando questionamos sobre a participação em projeto de assistência a produção agrícola e/ou pecuária oferecidos pelo Governo, todas as famílias afirmam que já se beneficiaram com os recursos provindos desses meios, citando principalmente o Agroamigo (62\%) Programa de Microfinança Rural do Banco do Nordeste, cujo principal objetivo é a melhoria do perfil social e econômico do agricultor familiar e o Programa Nacional de Fortalecimento da Agricultura Familiar - PRONAF (38\%), um programa do Governo Federal que objetiva o fortalecimento das atividades desenvolvidas pelo agricultor familiar por meio de financiamentos de atividades e serviços ligados a agropecuária, seja em estabelecimentos rurais ou áreas comunitárias visando a melhoria da qualidade de vida das famílias beneficiadas.

De acordo com entrevista direcionadas aos representantes locais, Associação de Moradores da comunidade e Sindicato Rural de Piripiri, as áreas da comunidade destinadas às produções agropecuárias são individuais, sendo que estas já foram beneficiadas com as políticas públicas, de incentivos a agropecuária com o Programa Nacional de Fortalecimento da Agricultura Familiar PRONAF; o Garantia Safra e o Bolsa Estiagem e atualmente se beneficiam com os financiamentos provenientes do PRONAF.

Destacaram que os critérios exigidos pelo INCRA para que as famílias tenham acesso aos programas de financiamento do Governo Federal, presentes na comunidade, estão relacionados, sobretudo a comprovação o exercício da atividade rural. Vale ressaltar que ambos os representantes consideram os projetos como de grande importância na complementação da renda familiar na comunidade.

Destacaram ainda que a comunidade enfrenta problemas no que se refere ao desenvolvimento das atividades agropecuárias, tais como: falta de água, educação, saúde, assistência técnica, Certificado de Imóvel Rural - CCIR, documento da terra e do tamanho do imóvel.

Observa-se que apesar de as famílias pesquisadas terem sido beneficiadas com os programas acima citados, e algumas serem assistidas pelo o bolsa família, tais projetos de financiamento não garantem a permanência das famílias na comunidade, sendo que as atividades agropecuárias de subsistência, provenientes de recursos próprios, ainda são a base de sustentação dessas famílias.

\section{CONSIDERAÇõES FINAIS}

As lutas pelo acesso aos direitos, por parte das comunidades remanescentes quilombolas, são constantes. A diversidade de tal luta na atualidade leva a uma reflexão sobre a exclusão social histórica com implicações étnico-raciais, em nosso país. Tendo em vista que assistimos a um processo de aceitação, por parte da sociedade, da mestiçagem como sendo uma das características mais marcantes do povo brasileiro, o mesmo acontece com a presença dos elementos africanos na base de diversas manifestações culturais populares.

0 acesso à terra através da regularização fundiária é extremamente importante, pois garante as ações de caráter social e afirmativas às comunidades quilombolas como o acesso à terra, infraestrutura, qualidade de vida, inclusão produtiva, desenvolvimento local e direitos da cidadania. 


\section{REFERÊNCIAS}

[1] Aguiar, Robério Bôto de; Gomes, José Roberto de Carvalho. Projeto cadastro de fontes de abastecimento por água subterrânea, estado do Piauí: diagnóstico do município de Piripiri. Fortaleza: CPRM Serviço Geológico do Brasil, 2004.

[2] Anjos, R. S. A. dos. O espaço geográfico dos remanescentes de antigos quilombos no Brasil. São Paulo: Terra Livre, n. 17, p. 139-154, $2^{\circ}$ semestre, 2001.

[3] Brasil. Constituição da República Federativa do Brasil: 1988. Câmara dos Deputados, Coordenação de Publicações. Brasília, DF, 1988.

[4] Ianni, Octávi. Origens Agrárias do Estado Brasileiro. São Paulo: Brasiliense, 1984.

[5] Instituto Brasileiro de Geografia e Estatística - Ibge. Censo demográfico 2010. Disponível em:<https://cidades.ibge.gov.br/brasil/pi/piripiri/panorama>. Acesso em 25 de jun. de 2018.

[6] Leite, Sérgio, [et.al.]. Impactos dos assentamentos: um estudo sobre o meio rural brasileiro. São Paulo: editora UNESP, 2004.

[7] Mattos, Regiane Augusto de. História e cultura afro-brasileira. 2.ed. São Paulo: contexto, 2012.

[8] Medeiros, Leonilde Sérvolo de. História dos movimentos sociais no campo. Rio de Janeiro FASE, 1989.

[9] Munanga, Kabengele. Origens africanas do Brasil contemporâneo: histórias, línguas, culturas e civilizações. 3.ed. São Paulo: Gaudí Editorial, 2012.

[10] Programa Brasil Quilombola. Guia de Políticas Públicas para Comunidades Quilombolas. Secretaria de Políticas de Promoção da Igualdade Racial. Brasília, 2013.

[11] Raffestin, Claude. Por uma Geografia do poder. São Paulo: Ática, 1993.

[12] Reis, João José; Gomes, dos Santos. Liberdade por um fio: história dos quilombos no Brasil. 1.ed. São Paulo: Claro Enigma, 2012.

[13] Souza, Laura Oliveira Carneiro de. Quilombos: identidade e história. 1.ed. Nova Fronteira, 2012.

[14] Souza, M. L. de. 0 território sobre o espaço e poder, autonomia e desenvolvimento. In: Castro, I. E. de; Gomes, P. C. da C.; Corrêa, R. L. (Org.). Geografia Conceitos e Temas. 6 ed. Rio de Janeiro: Bertrand, 2003. 


\section{Capítulo 11}

\section{Ambulantes e camelôs de Feira de Santana (BA): Origem e consolidação}

\section{Alessandra Oliveira Teles}

Resumo: 0 comércio é a atividade de maior relevância na organização espacial e socioeconômica de Feira de Santana. Responsável por sua implantação e consolidação, reflete, através de seus agentes, as permanências e mudanças que vem atravessando ao longo das décadas. Como objetivo estabeleceu-se analisar as permanências e mudanças promovidas no centro comercial a partir do comércio informal realizado por ambulantes e camelôs. A metodologia teve como base a formulação de questões a serem respondidas ao longo do estudo, perguntou-se: De que maneira o comércio informal promove a reafirmação da centralidade intraurbana em Feira de Santana e a complexidade no uso desse espaço demonstra a formação de territorialidades específicas? A realização de revisão teóricoconceitual contribuiu para a delimitação das informações necessárias. A pesquisa documental foi subdividida em duas bases, a bibliográfica, na qual foi realizado breve levantamento bibliográfico, através de consultas a livros, periódicos, teses, dissertações e monografias que serviram para a elaboração do referencial teórico. A partir disso, foi realizada uma segunda etapa, definida como observação de campo, teve como propósito o reconhecimento e caracterização da área de estudo através de pesquisa de campo. Os resultados foram tabulados e organizados como parte desse artigo. 


\section{INTRODUÇÃO}

A transformação da sociedade tem tornado relevante o estudo de temas específicos como o comércio. A produção, circulação e consumo se efetivam e materializam no espaço através da atividade comercial. Além disso, a centralidade urbana ratifica a importância do local perante a sua região.

Feira de Santana é um município que tem sua origem numa fazenda, como tantos outros na história da formação territorial brasileira, seu diferencial refere-se a ter se tornado ponto estratégico no pouso do gado bovino que se deslocava entre o semiárido baiano ou da região centro-oeste para Salvador e demais municípios do Recôncavo.

O comércio é a atividade de maior relevância na organização espacial e socioeconômica de Feira de Santana. Responsável por sua implantação e consolidação, reflete, através de seus agentes, as permanências e mudanças que vem atravessando ao longo das décadas. As relações de troca consolidam tal atividade, associada à localização estratégica da cidade, promoveram $o$ adensamento populacional de modo que o comércio informal se implantasse e se mantivesse. Mesmo com o projeto modernizador associado à abertura de rodovias e ao estabelecimento de um importante centro industrial, é no comércio onde se encontra a força da economia de Feira de Santana (CRUZ, 1999).

Este estudo tem ênfase no modo como o comércio informal promove a centralidade intra-urbana em Feira de Santana e configura territorialidades específicas. No contexto, o comércio informal foi pensado numa perspectiva relacionada ao espaço geográfico. Seu dinamismo demonstra os processos inerentes ao intervalo estudado, bem como, estruturas, funções e formas que mesmo diferenciadas constituem uma totalidade. 0 estudo regional, considerando as diferentes escalas geográficas, contribuem para um maior entendimento do comando regional e sua posição dentro da região metropolitana de modo a validar sua criação.

Escolher trabalhar com o comércio de rua levou em consideração diversos fatores. Como parte do comércio informal, sua presença é significativa nas ruas e avenidas do centro comercial, além de absorver boa parte da mão-de-obra que se torna desempregada a cada modificação das relações de trabalho nas diversas escalas geográficas. Considerou-se, na escolha do recorte, a relevância e prestígio do comércio de rua no centro comercial de Feira de Santana. Neste espaço é visível o fluxo de pessoas, elemento essencial para quem realiza venda direta.

\section{DEFINIÇÕES}

A atividade comercial age consideravelmente na organização espacial, a atuação dos agentes que a promovem é complexa e varia de acordo a espacialidade e a temporalidade analisada, uma vez que reflete a dinâmica social considerada. Com a consolidação da circulação e comunicação, promovendo uma integração e quase instantaneidade entre os lugares, as possibilidades de contato se tornaram praticamente totais. Essa realidade trouxe outra possibilidade, a realização de trocas com um mercado distante, promovendo uma quebra no isolamento produtivo bem como uma oferta extremamente variada, Santos (2006).

Essa produção pode ter sua comercialização realizada através de dois segmentos distintos dentro da mesma economia, o que o mesmo autor, em outra obra, define como circuito superior e inferior da economia. Segundo Santos (2008a), no circuito superior encontram-se as atividades de "capital intensivo" (p. 43) enquanto no circuito inferior: "[...] é constituído essencialmente por formas de fabricação não "capital intensivo", pelos serviços não-modernos fornecidos "a varejo" e pelo comércio não-moderno e de pequena dimensão".

0 comércio informal se estabelece com base na circulação de pessoas, consumidores em potencial, portanto a necessidade de ocupação dos espaços onde o movimento é maior. As áreas do centro, geralmente, representam esses espaços. Conforme Pintaudi (2007, p. 149) "O chamado comércio ambulante, por sua vez, é indicativo de trânsito intenso de pedestres, e, no centro de São Paulo, sua presença é marcante na paisagem". Via de regra, a discussão dos conceitos economia informal e informalidade operam uma cisão entre legal e ilegal, formal e informal, cindindo a própria economia urbana em compartimentos relativamente estanques. (OLIVEIRA, 2010, p. 3)

Souza (2013) define camelôs como "[...] indivíduos que tem um ponto, em que estrategicamente desenvolvem suas atividades, quer sejam entre as bancas ou nas ruas em panos espalhados pelo 
chão. " Para Montessoro (2006) os camelôs são aqueles que possuem um ponto estratégico para a realização de seu labor, ocupando tanto bancas nas ruas quanto camelódromos. Faz-se necessário destacar a discussão de Pintaudi (2007), pois não é possível homogeneizar a figura do trabalhador de rua, como se todos fossem iguais, uma vez que "diferenciam não só pela forma de propriedade das mercadorias e do ramo de comércio [...] como também pela 'propriedade do ponto', na rua em que se estabelecem, [...] deambulam, carregando nos braços os produtos que oferecem."

Yázigi (2000) nos traz um relevante tema que precisa ser discutido, o autor trata de toda uma legislação nacional acerca do uso dos bens públicos e privados, o que inclui o espaço público. 0 que nos chama a atenção se refere ao fato de que tanto esse autor como vários outros fazem uma discussão acerca do uso dos bens e do espaço público. Analisando a legislação em nível nacional, não há uma regulamentação para ambulantes, camelôs e similares, toda a legislação é pontual e está restrita as Câmaras Municipais de Vereadores.

Em Feira de Santana, a Prefeitura Municipal através da Secretaria Municipal de Desenvolvimento Econômico, procura, ao longo de sucessivas administrações, ordenar o uso do espaço público e destinar áreas específicas para que camelôs, ambulantes e outros possam desenvolver suas atividades. Na prática, tem-se o cumprimento do que é estabelecido pelos órgãos competentes no momento da organização, porém, com o passar do tempo, a falta de fiscalização e a elevação no número de pessoas comercializando nas ruas, os espaços outrora desocupados pelo poder público passam a abrigar novos trabalhadores que justificam falta de trabalho formal, desemprego, ausência de oportunidade em outros segmentos, necessidades familiares para ocupar os referidos espaços, entre outrasjustificativas.

O crescimento do comércio informal é facilmente percebido em Feira de Santana. A informalidade concentra os trabalhadores dispensados através da reestruturação produtiva e que necessitam sobreviver. A ausência de legalidade cria um ambiente de conflito com os comerciantes formais, na maioria, lojistas que arcam com todo tipo de carga tributária. 0 desemprego é a principal causa para o fortalecimento desse segmento, mesmo com a autonomia promovida pelo comércio informal. A falta de carteira assinada para a garantia de direitos mínimos pesa no momento de avaliar os elementos positivos do comércio informal.

O cenário apresentado revela um espaço de contradições. Os trabalhadores informais necessitam obter meios para a sua sobrevivência individual e familiar. Ao mesmo tempo, os comerciantes formais - além de serem pesadamente cobrados através de encargos trabalhistas e impostos governamentais nos diversos níveis - veem sua clientela dividida entre suas lojas e os camelôs arrumados em frente aos seus estabelecimentos. Enquanto isso, o poder público demonstra grande lentidão para resolver a situação de conflitos e necessidades de todos os segmentos envolvidos, inclusive da clientela, que ao mesmo tempo consome os produtos do comércio informal e critica a falta de espaço para a circulação nas vias da cidade.

\section{EVOLUÇÃO DOS AMBULANTES E CAMELÔS EM FEIRA DE SANTANA}

Durães aborda a presença do trabalhador de rua desde o século XV. No Brasil, os registros desta atividade datam do século XVII, com grande força no século XIX. Escravos, libertos, mestiços e brancos pobres buscavam sua sobrevivência em toda a sorte de atividades, atuando como carregadores, vendedores (aves, leite, frutas, carnes, etc.) ou prestando serviços como pedreiros, carpinteiros, lavadeiras, entre outros serviços. Segundo o autor "[...] no Brasil, o trabalho de rua é mais do que uma resultante de 'falhas' econômicas, como vai ser dito em meados do século XX; é sobretudo, parte culturalmente constitutivadasprópriascidades"(DURÃES,2013,p.118).

Em Feira de Santana, a atividade apresenta significativas transformações, desde sua espacialidade até a forma como é realizada. Evoluindo de mercadorias comercializadas na fazenda que dará origem ao município, para satisfazer as necessidades dos viajantes, que faziam pouso para o descanso de animais. Até chegar aos dias atuais, onde ambulantes e camelôs comercializam produtos provenientes dos mais diferentes lugares do país e do exterior.

Convém destacar que essa atividade apresenta expressivas transformações, desde sua espacialidade até a forma como é realizada. Essas mudanças apresentam três marcos significativos, a década de 1970, com a implantação do Centro de Abastecimento e transferência dos comerciantes. A década de 1990, com a implantação do Feiraguai e retirada dos camelôs que comercializavam produtos made in China na Praça da Bandeira e 2015 com o projeto de construção 
do camelódromo denominado de Shopping Popular. Quadro 1.

Quadro 1 - Transformações na espacialidade de Feira de Santana

\begin{tabular}{|c|c|c|}
\hline Período & Ação/Obra & Impactos e repercussões \\
\hline 1970 & $\begin{array}{c}\text { Centro de } \\
\text { Abastecimento }\end{array}$ & $\begin{array}{l}\text { Retirada dos feirantes; Dificuldades na comercialização; } \\
\text { Ruas do centrolivres para circulação de pedestres e veículos. }\end{array}$ \\
\hline 1990 & Feiraguai & $\begin{array}{l}\text { Ruas do centro ocupadas por ambulantes e camelôs; } \\
\text { Retirada dos ambulantes e camelôs para camelódromo; Consolidação do } \\
\text { Feiraguai. }\end{array}$ \\
\hline 2013 & $\begin{array}{l}\text { Pacto da } \\
\text { Feira/Shopping } \\
\text { Popular }\end{array}$ & $\begin{array}{l}\text { Ruas do centro ocupadas por ambulantes e camelôs; Projeto para retirada } \\
\text { dos ambulantes e camelôs com } \\
\text { construção do Shopping Popular; Conflitos. }\end{array}$ \\
\hline
\end{tabular}

Elaboração: TELES, 2016.

A organização espacial urbana de Feira de Santana é uma característica relevante e singular na sua evolução socioeconômica e regional. A atividade consolidada no seu centro comercial colabora na manutenção da centralidade urbana. Também fortalece seu papel de centro regional, pois sua realização neste espaço permite a formação de uma rede comercial em nível local, regional e nacional. Projetando Feira de Santana numa escala internacional através da comercialização dos produtos made in China.

A redefinição pensada para o centro comercial de Feira de Santana transformou-se desde a década de 1980 em espaço de conflitos. Resultado dos seus diferentes usos e das diferentes perspectivas de produção e reprodução de renda gerada nas ruas. Realizou-se um levantamento do comércio formal e informal que compõe o universo desta pesquisa. Foram identificados os estabelecimentos comerciais e a disposição de ambulantes e camelôs ao longo dos logradouros resultando nos croquis que seguem.

A análise dos dados obtidos pelos questionários aplicados entre ambulantes e camelôs, consumidores e o levantamento de informações que resultaram na elaboração desses croquis permitiram a avaliação da formação de um circuito inferior da economia urbana como proposto por Santos (2008a) com relevante influência do circuito superior.

A configuração espacial planejada para o centro comercial com a transferência da feira livre para o Centro de Abastecimento não foi alcançada. Ao longo da década de 1980, 1990 e 2000 o número de pessoas em busca de ocupação superava os postos de trabalho, e cada vez mais barracas apareciam nas calçadas da cidade.

Dos cinco logradouros pesquisados o que apresenta a maior concentração de ambulantes e camelôs é a rua Sales Barbosa (Croqui 1). Impressionante como se apertam no calçadão, são barracas, carrosde-mão, araras encostadas pelas paredes entre uma loja e outra, pessoas com cestos, mercadorias nas mãos, mercadorias estendidas ao chão.

A rua Sales Barbosa não apresenta lojas de porte nacional, as de porte regional como Mersan Calçados e Rainha Enxovais aparecem pouco pela quantidade de estabelecimentos presentes no logradouro que está delimitado entre a avenida Getúlio Vargas a praça Eduardo Froes da Mota. Nessa rua, a concentração de lojas de confecções é tão intensa quanto o número de ambulantes e camelôs que trabalham com confecções e calçados.

Poucas lojas colocam mercadorias nas portas para disputar clientes ou impedir ambulantes e camelôs de ocuparem os espaços. Por toda a rua Sales Barbosa só encontramos com essa prática a loja Ao Avesso, Laísa Confecções, Acessorium Bijoux, Canal da Moda, Central do Jeans, Kamy's Modas, LM Confecções, Petty Modas e Tyrraf Modas. Historicamente os conflitos entre comerciantes formais e ambulantes e camelôs ocorrem, os jornais registram que desde a chegada dos últimos que os comerciantes formais solicitam providências por parte do poder público e ainda hoje os comerciantes reclamam dos prejuízos causados pela ocupação desordenada do calçadão por parte de ambulantes e camelôs. 
Geografia no Século XXI- Volume 3

Croqui 1 - Ambulantes e camelôs na rua Sales Barbosa

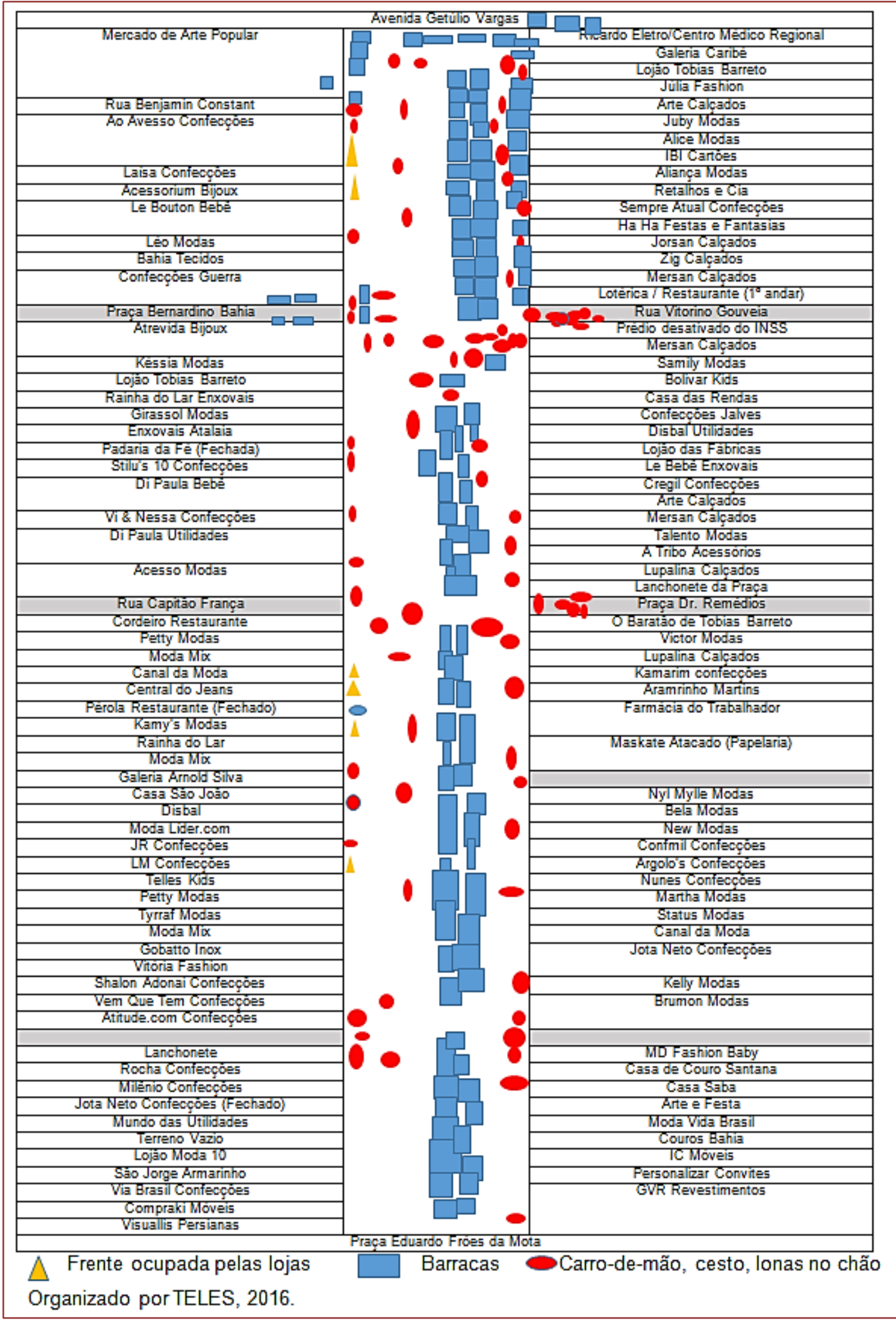


Na avenida Senhor dos Passos, o trecho pesquisado está delimitado entre a avenida Getúlio Vargas e a rua Carlos Gomes, onde encontramos importantes representações do circuito superior da economia urbana. Croqui 2. Estão presentes dois bancos de porte nacional e internacional, respectivamente, Bradesco e Santander, lojas de porte nacional, como Casas Bahia, Ricardo Eletro, Farmácia Pague Menos, Magazine Luiza, Subway, Marisa, C\&A e Riachuelo. Diversas lojas de alcance regional como, por exemplo, Kosmechik, Mersan Calçados, Romanel Jóias e Rainha Enxovais e lojas locais, com elevada dinâmica, como Disbal, Jorsan Calçados e Brandão Jóias.

A concentração de ambulantes e camelôs ocorre com destaque à frente das lojas da Casas Bahia e banco Santander, com o fechamento da Esplanda, loja de departamentos, à frente da loja tem apresentado uma crescente aglomeração de ambulantes a cada dia que se passa pelo local. No ponto de ônibus, localizado na praça Bernardino Bahia, que fica na esquina da loja Marisa e da C\&A, a ocupação é constante e intensa por ambulantes e camelôs. A Riachuelo também apresenta constante presença de ambulantes, em especial, aqueles com carros-de-mão e carrinhos (saladas de frutas, milho cozido, tapioca, sorvete são os que mais aparecem).

Na praça do Nordestino o comércio formal de maior representação é o Mundo do Real, uma loja que iniciou como vendendo produtos made in China por $\mathrm{R} \$ 1,99$ e transformou numa loja de utilidades domésticas. Muito ampla, ocupa à frente com seus próprios produtos, não permitindo a presença de ambulantes e camelôs. A loja vizinha, uma hamburgueria, coloca um balcão com lanches e cadeiras, também não permite que outros exerçam nenhum tipo de atividade em sua frente. E a Fast Festa expõe os produtos de festa também ocupando todo o espaço à sua frente. Assim mesmo existem muitas barracas, carros-de-mão e carrinhos adaptados comercializando neste logradouro. Croqui 3.

Os ambulantes e camelôs presentes na rua Benjamin Constant vivem uma particularidade em relação aos demais. A PMFS realizou uma reforma no Mercado de Arte Popular e colocou uma grade no seu entorno. Todos os ambulantes e camelôs que negociavam junto às paredes do mercado tiveram que se afastar aproximadamente 1,0 metro da atual grade. A rua que é estreita ficou bem difícil para a circulação. Já havia duas filas de barracas que se aproximaram mais ainda com essa mudança.

Outro fato a destacar é a grande concentração de ambulantes voltados para a rua Sales Barbosa, acredita-se que tal fato ocorria, por ser a rua de maior movimento de pedestres. Em parágrafos anteriores, destacamos que as lojas Ponto do Fogão, Kio do Fogão e Casas do Fogão ocupam totalmente suas frentes de lojas com mercadorias. Ao mesmo tempo, alguns camelôs revelaram existir um bom relacionamento entre eles e os donos das lojas. A energia que utilizam em suas máquinas é adquirida através de extensão ligada nas redes das lojas e no período de pagar a conta dão uma contribuição, teoricamente, proporcional ao que utilizam. Muitos não levam suas ferramentas ou outros materiais de trabalho para casa, guardam nas lojas ao fim de cada expediente. Quando necessitam ir ao sanitário utilizam nas lojas que já tem um relacionamento estabelecido. Com estas informações, entende-se que há uma relação de conflito, mas também de cumplicidade, pelo menos para o camelô. 
Croqui 2 - Ambulantes e camelôs na avenida Senhor dos Passos da rua

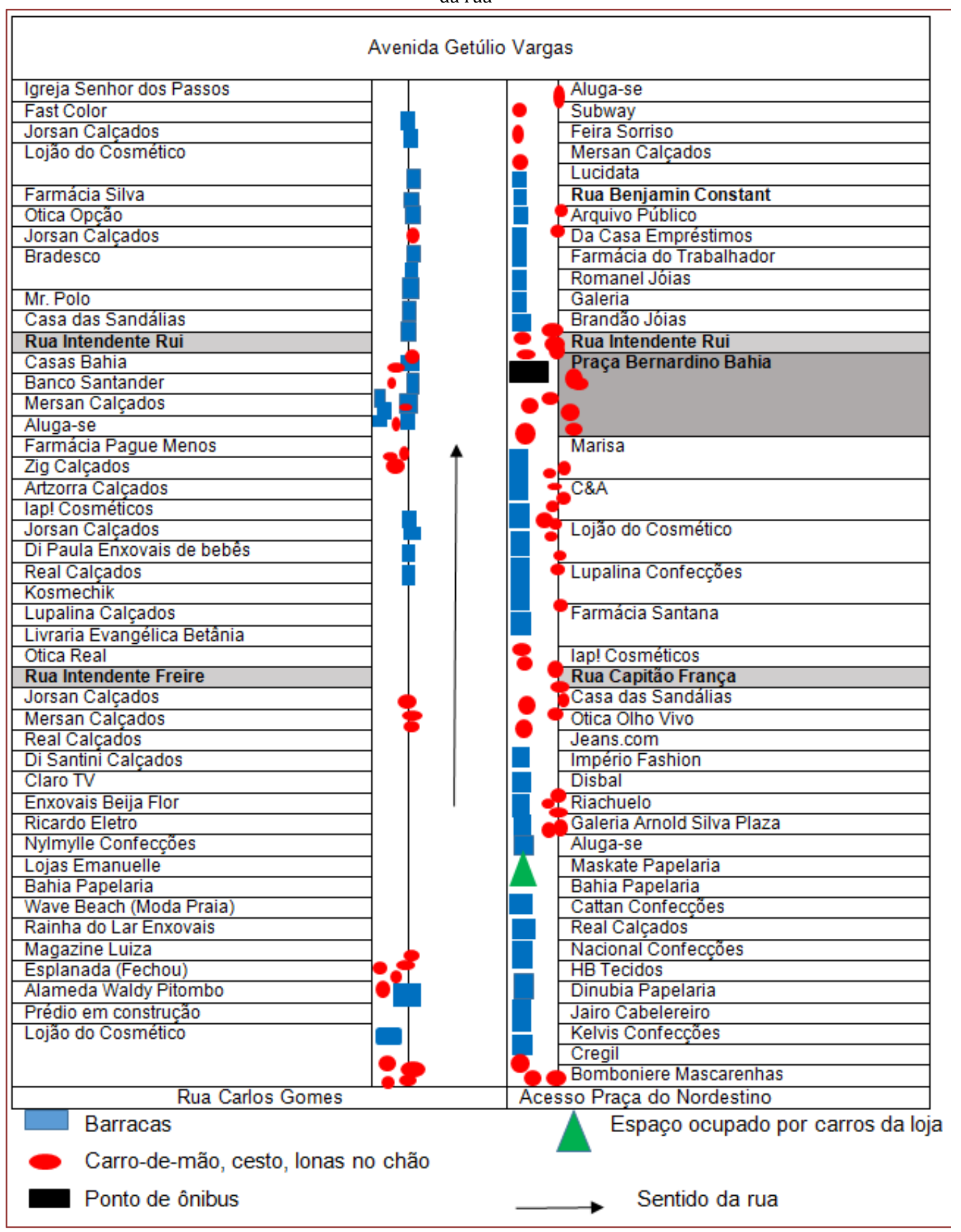

Organização: TELES, 2016. 
Croqui 3 - Ambulantes e camelôs na Praça do Nordestino

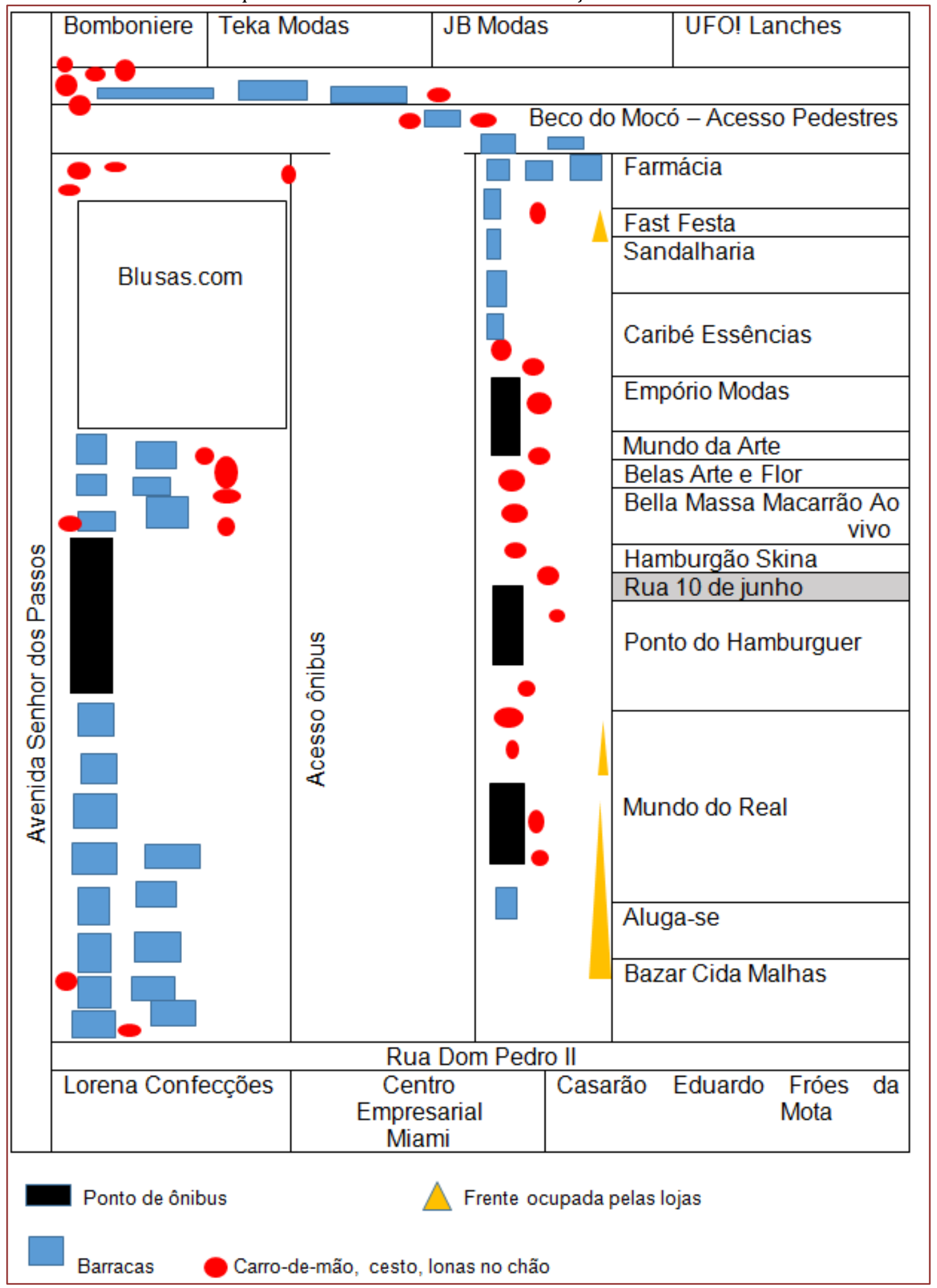


Croqui 4 - Ambulantes e camelôs na rua Benjamin Constant

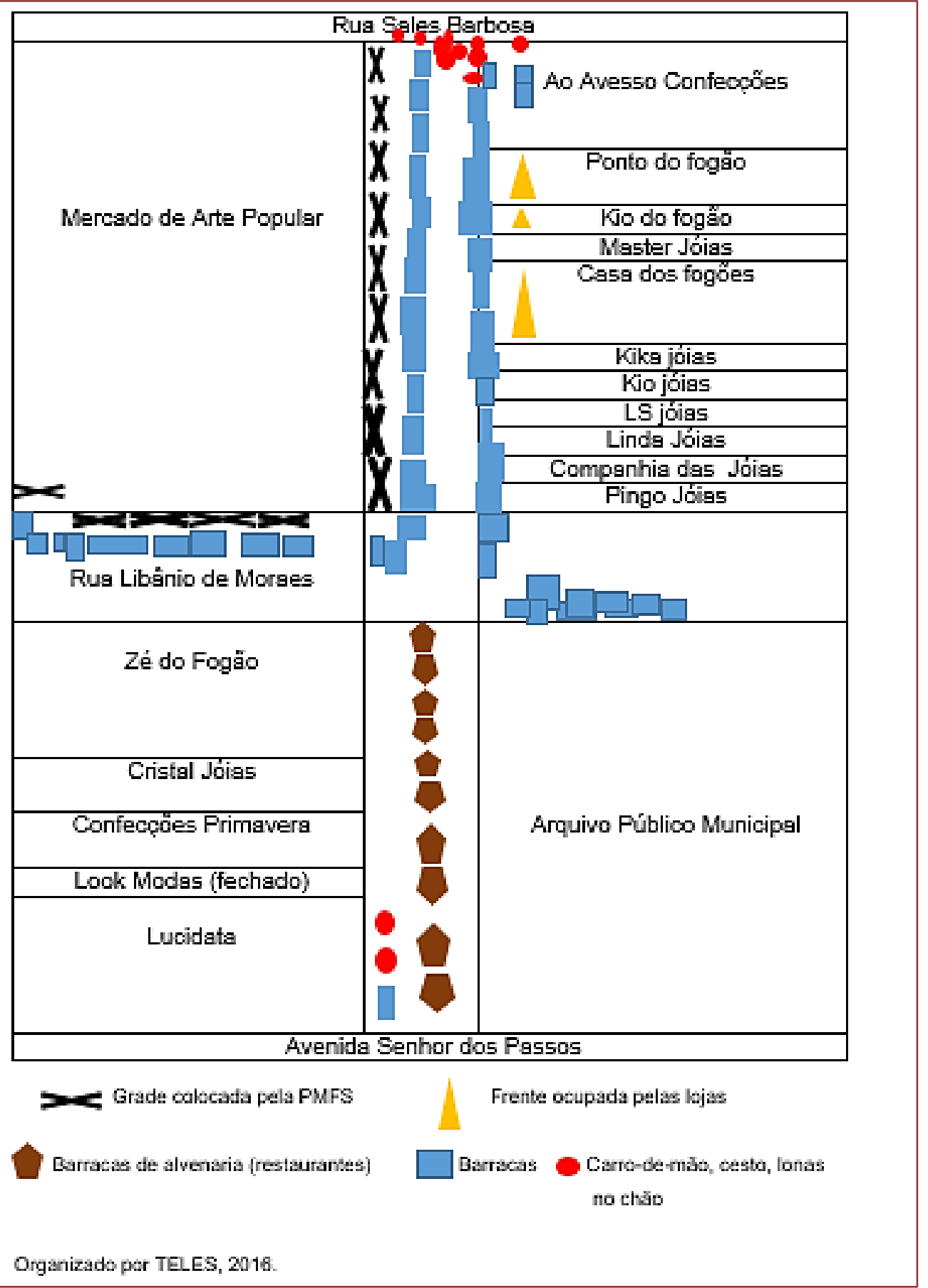


Quando questionados sobre a contrapartida para a loja, o cliente foi citado por todos como elementochave nessa relação.

Não vê a mulher que estava aqui? Veio afiar um alicate, enquanto eu fazia o serviço ela entrou na loja e saiu com uma sacolinha, a senhora reparou? Ela mesmo disse, nem tava precisando das bijuterias, mas aproveitou que estava esperando eu afiar e fez umas comprinhas, a gente aqui na rua dá movimento pras lojas. (Camelô entrevistado).

Outro destaque para a rua Benjamin Constant deve-se a presença de barracas de alvenaria onde funcionam pequenos restaurantes. Croqui 4. Apesar de não conseguir descobrir a origem da água que utilizam, conversamos com um dos responsáveis de uma dessas unidades. 0 mesmo informou que foi cadastrado pelos funcionários da PMFS e "fazer o que se tiver que ir pro shopping, vai, se aqui nem ali é meu".

A rua Marechal Deodoro é o maior símbolo de permanência da feira livre que ocorreu no centro da cidade até 1970. Croqui 5. Alguns dos que trabalham nessa rua são filhos e netos de pessoas que atuaram como feirante e foram transferidos para o Centro de Abastecimento e não conseguiram tirar o sustento e retornaram aos poucos para o centro comercial. Outros não foram contemplados com uma vaga e precisavam sobreviver e tantos outros porque ficaram desempregados e não tiveram outra oportunidade.

Delimitada pela avenida Monsenhor Mário Pessoa e a avenida Getúlio Vargas, a circulação de carros é intensa, o que não permite a ocupação do seu canteiro central. Lojas de porte nacional como Ricardo Eletro, Magazine Luiza e Casas Bahia, de porte regional como Rainha Enxovais, GBarbosa supermercados, Mersan Calçados estão presentes.

A concentração de ambulantes e camelôs é intensa, em certas situações formam fileiras de 3, 4 barracas ocupando a calçada e avançando pela rua, tomando o espaço que deveria ser de estacionamento de veículos. Em frente ao GBarbosa a situação é mais agravada, a quantidade de carros- de-mão com legumes, verduras e frutas é de tal forma que torna-se difícil a representação no croqui. 0 próprio supermercado instalou um alambrado na tentativa de conter o avanço dos carros-de-mão em direção às suas portas. 0 que mais chama a atenção, deve-se ao fato da clientela do supermercado adquirir os mais variados produtos em suas dependências, porém, frutas, legumes e verduras são compradas desses ambulantes e camelôs que ficam à porta. Quando questionados, alegam que os produtos por estes vendidos têm preços menores. Foi-se verificar e nem sempre esse fato é realidade, pois houveram situações e períodos nos quais produtos como abóbora, tomate e banana estavam com preço menor no supermercado em relação aos ambulantes e camelôs. Mesmo assim, existe uma cultura de quem frequenta esse logradouro de manter a compra desses produtos entre os ambulantes e camelôs.

0 processo de industrialização criou a falsa ideia de ocupação de mão-de-obra. Muitos governos estaduais, inclusive na Bahia, para justificar o investimento em plantas industriais da iniciativa privada, nos seus estados, colocaram na mídia a informação relacionada a geração de significativa quantidade de postos de trabalho, o que na realidade não ocorreu (TEIXEIRA e GUERRA, 2000). Neste cenário, os trabalhadores informais, representado sobretudo por ambulantes e camelôs compõem a categoria que apresenta o maior crescimento. Desempregados e indivíduos de municípios diversos, especialmente daqueles com predominância de atividades primárias vão promover um aumento expressivo no comércio de rua, como escreve Maia $(2015$, p. 456) “0 chamado comércio de rua, em parte é integrante desse setor e vem funcionando como fator de estabilização social para o indivíduo desempregado".

Feira de Santana passou por um processo de expansão urbana nas últimas décadas. A ocupação imobiliária em praticamente todas as direções é evidente. Mesmo assim, suas principais atividades estão concentradas no centro. E nesse disputado espaço, o comércio informal se instala, ou se transforma, considerando a feira livre que existiu até meados da década de 1970. Demonstra que embora o surgimento de subcentros, com diversas atividades que também estão presentes no centro - inclusive ambulantes e camelôs - a cidade ainda se configura monocêntrica. É nesse espaço central onde as atividades importantes estão concentradas com destaque para os bancos e clínicas especializadas.

A primeira tentativa de organização do centro da cidade ocorre entre meados da década de 1960 e 70, quando é construído o Centro de Abastecimento e a feira livre que acontece no centro da cidade 
é transferida para este espaço. Com o passar do tempo, os comerciantes pouco a pouco foram ocupando as calçadas novamente. Com a alegação de não conseguir se adaptar ou a clientela não ter acompanhado para os novos espaços. Realidade vivenciada em locais como Fortaleza, segundo Dantas (2005, p. 7): "Por tratar-se de atividade nutrida exclusivamente do fluxo contínuo e maciço de pedestres, não foi de se estranhar seu retorno ao Centro, apesar das pressões contrárias e de continuidade da utilização da violência pelo rapa (Guarda Municipal) ".

Croqui 5 - Ambulantes e camelôs na rua Marechal Deodoro

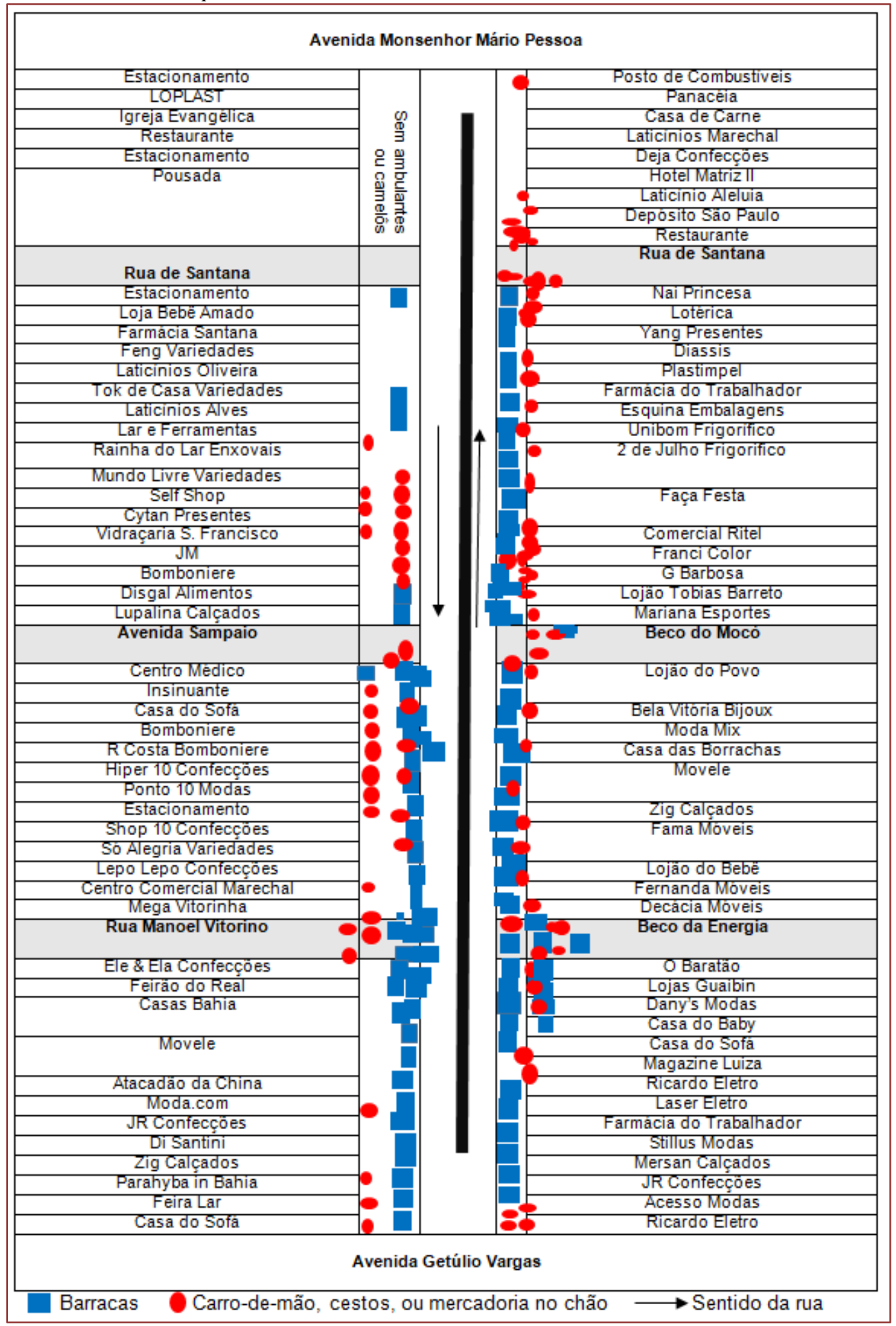


Os ambulantes e camelôs presentes nas ruas pesquisadas constituem uma complexidade no cenário de Feira de Santana. Desenvolvem suas atividades de forma precária, poucos são os que conseguiram alcançar um nível de estabilidade e recurso que os colocaram numa situação de segurança financeira. A grande maioria passa por privações e dificuldades para que possa garantir seu sustento.

Existem logradouros nos quais a concentração de barracas é maior, as ruas Sales Barbosa e Marechal Deodoro são as que apresentam uma maior quantidade, além da grande aglomeração e desordem. De tal modo, as frentes das lojas perdem a visibilidade para os que circulam pelo local.

Como pode ser observado no gráfico 1 a organização é feita basicamente a partir de barracas, predominam as de zinco, metal e lona, e de madeira. A depender do logradouro tem-se uma maior ou menor predominância de uma dessas três armações. Também encontramos lona no chão, barraca de fibra, pessoas com mercadorias em cestos, carro-de-mão, carrinho adaptado, bicicletas, araras e até balcão, estas informações compõem o eixo horizontal do gráfico.

Gráfico 1 - Tipos de equipamentos utilizados por ambulantes e camelôs no centro comercial de Feira de Santana - 2015

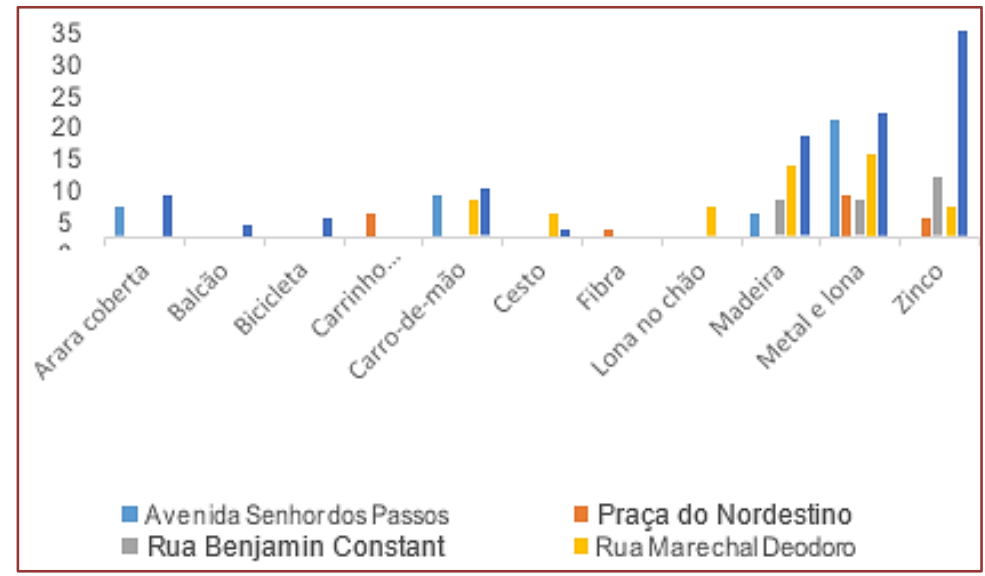

O gráfico acima apresenta no seu eixo vertical informações referentes a frequência na qual cada ambulante e camelô respondeu em relação ao tipo de equipamento utilizado. A arara coberta predomina entre ambulantes e camelôs presentes na avenida Senhor dos Passos, 5 entrevistados responderam utilizar esse tipo de equipamento. Nesse logradouro também foram encontrados 7 carros-de-mão, 4 barracas de madeira e 20 barracas de metal e lona.

Na praça do Nordestino, entre os entrevistados, 4 utilizam carrinho adaptado, 1 barraca de fibra, 7 barracas de metal e lona e 3 barracas de zinco. Na rua Benjamin Constant, os ambulantes e camelôs utilizam barraca de madeira, 6 entrevistados, barraca de metal e lona, também 6 entrevistados e barraca de zinco, 10 entrevistados.

A rua Marechal Deodoro tem a predominância no uso da barraca de metal e lona, 14 entrevistados. 12 utilizam barraca de madeira, 6 estavam com carro-de-mão. 5 utilizam barraca de zinco e 4 estavam comercializando com cesto. Na rua Sales Barbosa encontra-se a maior variedade em tipos de equipamentos utilizados pelos ambulantes e camelôs. 7 utilizam arara coberta, 2 estavam com balcão, 3 em bicicletas, 8 com carro-de-mão, 1 com cesto, 17 utilizam barraca de madeira, 21 barracas de metal e lona e as barracas de zinco apresentam uma predominância com 36 ambulantes ecamelôs.

Percebemos a variedade de equipamentos utilizados para a realização da venda por parte de ambulantes e camelôs. Aqueles que se utilizam de carro-de-mão, cesto, ou lona no chão representam o segmento que adquire pequenas quantidades de mercadorias, às vezes, entre os próprios camelôs que possuem barracas ao longo dos logradouros estudados para tentar uma revenda e aquisição de margem mínima de lucro. São esses que vivem no limite da sobrevivência, buscando os recursos mínimos para suas necessidades como comer e morar. Esse é o segmento dos ambulantes e camelôs que obtém os menores lucros e que realizam mais horas de trabalho, mesmo não possuindo patrão.

Para Raffestin (1993) a formação de um território é resultante das ações promovidas por agentes que 
buscam a transformação do espaço para alcançar seus objetivos. Segundo o autor o território é um espaço transformado pelo trabalho e demonstra uma complexa relação de poder e domínio referindo-se a consolidação de uma ou várias territorialidades. A presença de ambulantes e camelôs de origens variadas determinam a formação de uma rede que consolida um campo de ação e poder com repercussão tanto nas interações espaciais como na constituição de território. Mapa 1.

Mapa 1 - Municípios de origem dos ambulantes e camelôs de Feira de Santana

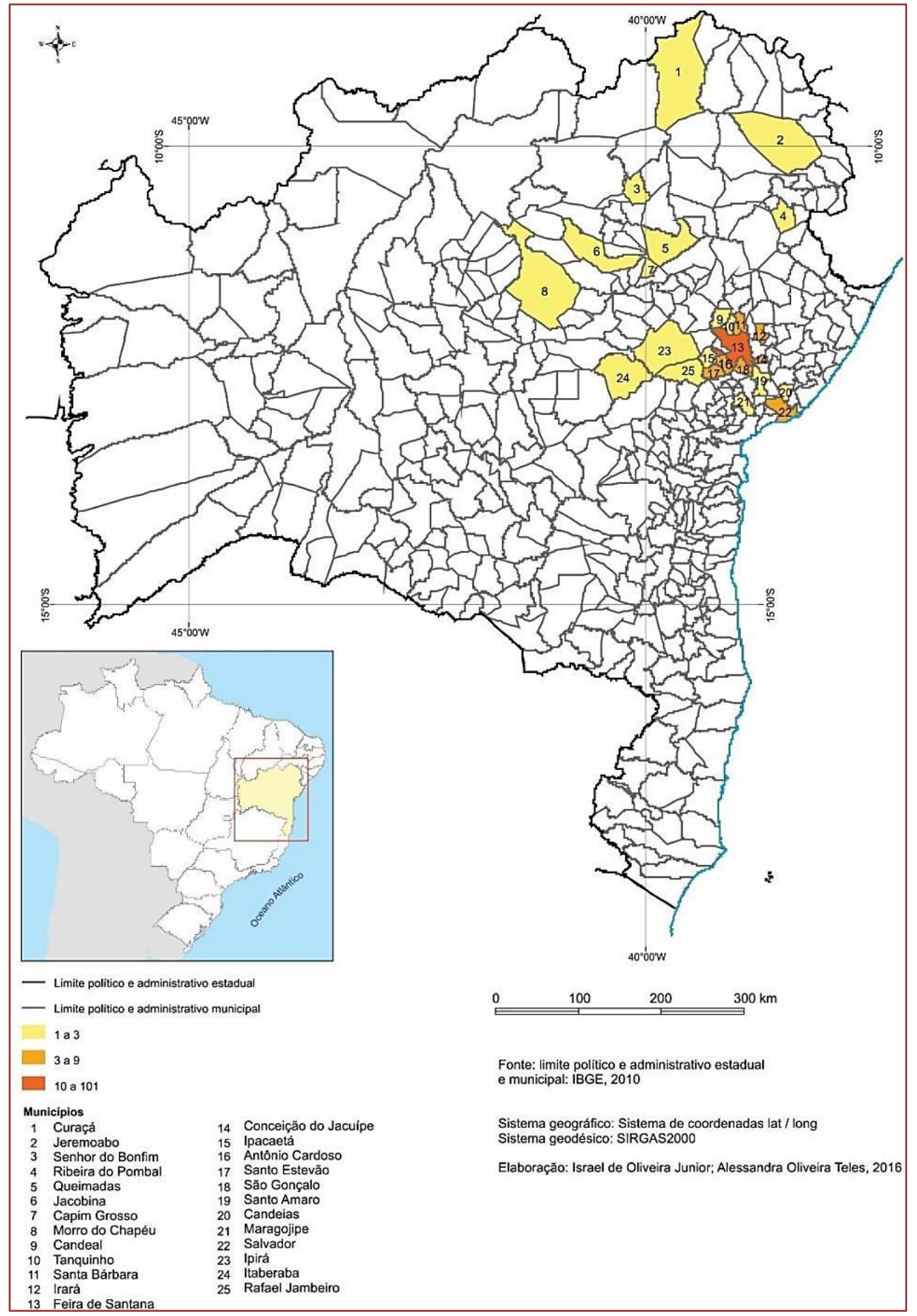


Entre os pesquisados a predominância se dá entre os nascidos no próprio município. Dos 23 municípios que compõem a microrregião de Feira de Santana, 10 foram citados durante a pesquisa de campo como local de nascimento, são eles, Antonio Cardoso, Conceição do Jacuípe, Ipecaetá, Ipirá, Irará, Rafael Jambeiro, Santa Bárbara, Santo Estevão, São Gonçalo dos Campos e Tanquinho.

Dentre as 7 mesorregiões do estado da Bahia, 5 tiveram municípios citados como local de nascimento entre ambulantes e camelôs. Candeal, Jeremoabo, Queimadas e Ribeira do Pombal, componentes da mesorregião geográfica Nordeste Baiano. Os municípios de Candeias, Maragogipe, Salvador, e Santo Amaro compõem a Região Metropolitana de Salvador. O Centro Norte Baiano apresenta os municípios de Capim Grosso, Itaberaba, Jacobina, Morro do Chapéu e Senhor do Bonfim, enquanto da mesorregião vale Sanfranciscana houve uma citação, o município de Curaçá. Da mesorregião geográfica Centro Sul Baiano o município de Milagres foi citado.

Um dos entrevistados confirmou ter nascido no município de Adamantina, estado de São Paulo. Essa informação nos ajuda a compreender o processo migratório e polarizador desse município e consolidar sua posição enquanto centro regional, pois quando questionados sobre o motivo de estarem aqui, mais de $50 \%$ afirmaram a localização do município e a quantidade de pessoas que por aqui circulam.

Em relação ao tempo de trabalho, esse dado revela que existe uma população que vem há muito tempo sobrevivendo desta atividade, tabela 1 . Dividimos os entrevistados em faixas de intervalo de 5 anos. Entre os 217 entrevistados, 41 responderam ter entre algumas semanas e 5 anos de trabalho como ambulante e camelô. Na faixa definida entre 6 e 10 anos, existem 35 pessoas. Dentre os pesquisados, foram identificados 50 ambulantes e camelôs trabalhando entre 11 e 15 anos. Entre 16 e 20 anos são 49 entrevistados, enquanto na faixa correspondente a 21 e 25 anos são 15 ambulantes e camelôs. Para a faixa entre 26 e 30 encontrou-se 21 pesquisados e com mais de 31 anos existem 06 ambulantes e camelôs nas ruas de Feira de Santana.

Tabela 1 - Tempo de trabalho dos ambulantes e camelôs em Feira de Santana - 2015

\begin{tabular}{|c|c|c|c|c|c|c|c|}
\hline \multirow[b]{2}{*}{$\begin{array}{l}\text { Tempo de } \\
\text { trabalho } \\
\text { (anos) }\end{array}$} & \multirow[b]{2}{*}{$\begin{array}{c}\text { Período } \\
\text { (anos) }\end{array}$} & \multicolumn{6}{|c|}{ Número de comerciantes } \\
\hline & & $\begin{array}{c}\text { Avenida } \\
\text { Senhor } \\
\text { dosPassos }\end{array}$ & $\begin{array}{l}\text { Praça do } \\
\text { Nordestino }\end{array}$ & $\begin{array}{c}\text { Rua } \\
\text { Benjamin } \\
\text { Constant }\end{array}$ & $\begin{array}{c}\text { Rua } \\
\text { Marechal } \\
\text { Deodoro }\end{array}$ & $\begin{array}{c}\text { Rua Sales } \\
\text { Barbosa }\end{array}$ & Total \\
\hline $0-5$ & $2015-2011$ & 09 & 04 & -- & 07 & 21 & 41 \\
\hline $6-10$ & $2010-2006$ & 09 & 04 & -- & 09 & 13 & 35 \\
\hline $11-15$ & $2005-2001$ & 11 & 05 & 07 & 07 & 20 & 50 \\
\hline $16-20$ & 2000-1996 & 06 & -- & 04 & 10 & 29 & 49 \\
\hline $21-25$ & 1995-1991 & 02 & 02 & -- & 08 & 03 & 15 \\
\hline $26-30$ & 1990-1986 & 01 & -- & 07 & 03 & 10 & 21 \\
\hline+31 & $1985-\ldots$ & -- & -- & 04 & 02 & -- & 06 \\
\hline
\end{tabular}

Fonte: Pesquisa de campo, 2015.

Ao efetuar uma soma do número de comerciantes entrevistados, tomando como parâmetro o período que estão nas ruas, entre 1991 até 2015, pode-se perceber que dos 217 entrevistados 190 encontram-se inseridos nesse intervalo de tempo. Todos justificaram sua atuação na rua por não conseguirem uma vaga no mercado formal de trabalho. Aqueles que já ocuparam uma vaga nesse segmento informaram que foram demitidos e não conseguiram uma nova colocação, como alternativa para adquirir algum tipo de remuneração aceitaram atuar na atividade de ambulante ou camelô. Continuaram nas ruas por não conseguir outra vez uma vaga no mercado formal de trabalho.

Ocorre uma expressiva elevação no número de desempregados. Resultado da conjuntura econômica que o país passa e nas mudanças na dinâmica urbana com uma elevação na taxa de urbanização. Cidades médias e grandes, principalmente, em decorrência do processo de migração das populações que buscam novos postos de trabalho. Uma vez que o setor primário recebe uma carga tecnológica para a produção sem comparativos anteriores. Desse modo, na ausência de um mercado formal de trabalho, essa massa economicamente ativa e necessitada de uma forma de sobrevivência encontra no comércio de rua um meio de obter seu sustento. 


\section{CONSIDERAÇÕES FINAIS}

O comércio informal em Feira de Santana, particularmente o que ocorre nas ruas da cidade, passou por significativas transformações no intervalo que marca a origem do município e da cidade com a feira livre e a feira de gado bovino até a atual organização, na qual os produtos industrializados predominam. Esta situação é um indicativo de que houveram inclusões, nesta atividade, de processos de acumulação de capital.

Considerando o impacto da reestruturação produtiva no mundo do trabalho, este comércio informal apresenta papel singular na manutenção da sobrevivência do trabalhador. Ao absorver a mão- de-obra desempregada, oriunda de outros segmentos apresenta dupla função, diminuição no número de pessoas desocupadas e sem rendimentos, e permite a estes o poder de consumo que lhe seria negado caso não tivesse nenhuma forma de negociar sua força de trabalho.

Para que essa atividade tenha a dinâmica identificada ao longo da pesquisa fez-se necessário destacar o papel da cidade de Feira de Santana. A centralidade foi considerada como pilar para a organização dessa atividade na área central de Feira de Santana, demonstrando que a cidade mantém- se monocêntrica, apesar das modificações advindas do seu processo de expansão urbana tão concreto e visível nas últimas décadas. Não só as classes de menor poder aquisitivo procuram o centro para consumir, mas, principalmente, consumidores das mais variadas cidades e de outros estados. Sua hegemonia em relação aos bairros continua fortalecida. Por mais que tenha ocorrido a transferência de comércio e serviços para outros espaços da cidade, a área central reúne o melhor percurso de transporte coletivo e as facilidades de acesso a diferentes usos num espaço de tempo consideradocurto.

O uso do espaço público para fins particulares é outro ponto que não pode ser desconsiderado. 0 número de conflitos gerados, envolvendo diferentes agentes, é elevado e complexo. 0 poder público, por ser o responsável pela gestão e manutenção desse espaço procura normatizá-lo com a intenção de impor um ordenamento territorial e atender os interesses divergentes daqueles que o utilizam sejam cidadãos, comerciantes formais ou informais.

\section{REFERÊNCIAS}

[1] Cruz, Rossine C. A inserção de Feira de Santana (BA) nos processos de integração produtiva e de desconcentração econômica nacional. 1999. Tese (Doutorado em Economia) - Instituto de Economia. Universidade Estadual de Campinas, Campinas, 1999. $333 \mathrm{f}$.

[2] Dantas, Eustógio Wanderley C. Apropriação do Espaço Público pelo Comércio Ambulante: FortalezaCeará-Brasil em Evidência (1975 a 1995). Scripta Nova. Universidad de Barcelona, vol. IX, n. 202, 1 de diciembre de 2005. Disponível em http://www.ub.edu/geocrit/sn/sn-202.htm . Acesso em 17 de julho de 2015.

[3] Durães, Bruno J. R. Camelôs Globais ou de Tecnologia: novos proletários da acumulação. Salvador: EDUFBA, 2013.

[4] Maia, Ana Cláudia N. Comércio de Rua X Poder Público: 0 Caso da Cidade de Salvador (BA). Bahia: Análise \& Dados. Salvador, v. 25, n. 2, p. 455-474, abr./jun. 2015.

[5] Montessoro, Cláudia Cristina L. Centralidade Urbana e Comércio Informal: Os Novos Espaços de Consumo no Centro de Anápolis - GO. Universidade Estadual Paulista. Faculdade de Ciências e Tecnologia. Presidente Prudente, 2006. Tese de Doutorado, 355 p.

[6] Oliveira, Edilson Luís. Circuito Inferior da Economia Urbana e Mídia Impressa em Londrina/PR. Anais do VI Encontro Nacional de Geógrafos. Porto Alegre, 2010. Disponível em www.agb.org.br . Acesso em 17 de janeiro de 2014.

[7] Pintaudi, Silvana M. A Cidade e as Formas do Comércio. In: CARLOS, A. F. A. (Org.) Novos Caminhos da Geografia. 5 ed.; São Paulo: Contexto, 2007. (Caminhos da Geografia).

[8] Raffestin, Claude. Por uma Geografia do Poder. São Paulo: Ática, 1993.

[9] Santos. Milton. O Espaço Dividido: Os Dois Circuitos da Economia. São Paulo: Edusp, 2008a. 1 reimpressão.

[10] . Por Uma Outra Globalização: Do pensamento único à consciência universal. 13 ed., Rio de Janeiro: Record, 2006. 
[11] souza, Elisete Cerqueira. Organização Espacial e a Utilização do Espaço Público pelos Feirantes e Ambulantes da Rua Marechal Deodoro da Fonseca, Feira de Santana - BA. Monografia de Conclusão de Curso, Departamento de Ciências Humanas e Filosofia, Universidade Estadual de Feira de Santana. 2013. 67 f.

[12] Teixeira, Francisco, Guerra, Oswaldo. 50 anos da industrialização baiana: do enigma a uma dinâmica exógena e espasmódica. Bahia: Análise \& Dados. Salvador: SEI, v. 10, n. 1, jul. 2000, p. 87-99.

[13] Yágizi, Eduardo. O Mundo das Calçadas. São Paulo: Humanitas/FFLCH/Usp; Imprensa Oficial do Estado, 2000. 


\title{
Capítulo 12
}

\section{A segregação socioespacial do bairro Nova Caicó: refletindo sobre os espaços opacos Caicoenses}

\author{
Iapony Rodrigues Galvão \\ Djalma Amâncio da Silva Neto \\ Lucas Henrique Lima Alves \\ Ricardo Araújo de Lemos
}

Resumo: A cidade de Caicó/RN é a principal cidade da mesorregião central do Rio Grande do Norte, localizando-se na microrregião do Seridó ocidental. De acordo com a Região de Influência das Cidades - REGIC, organizado pelo IBGE - Instituto Brasileiro de Geografia e Estatística, Caicó é um centro sub-regional A, influenciando diferentes municípios do Rio Grande do Norte e da Paraíba. Apesar de ser uma cidade tradicional e muito importante para os potiguares, há a existência de localidades no espaço urbano caicoense cidade com uma infraestrutura consideravelmente precarizada, consequência de um processo de segregação socioespacial, distante da realidade conhecida pelos turistas e visitantes de Caicó. Essa porção espacial contraditória, muitas vezes é esquecida pelo poder público, tornando-se, assim, numa perspectiva dialética, em um espaço opaco. Nessa perspectiva, a presente pesquisa teve como objetivo estudar a segregação socioespacial no bairro Nova Caicó, visto que o mesmo se encontra em uma área periférica da cidade, sendo construído socialmente por uma população com menor poder aquisitivo. Assim, para compreender a formação deste processo segregatório, foram realizadas pesquisas bibliográficas acerca da problemática acima destacada, registros fotográficos das formas espaciais e dos serviços públicos oferecidos no bairro, bem como a realização da pesquisa in loco, com aplicação de questionários, conversamos com os residentes e discussão sobre os principais problemas e necessidades enfrentadas no bairro. A partir deste diálogo, associado à obtenção de dados, foi possível evidenciar a escassa ação do poder público na comunidade, para que, assim, fosse possível uma compreensão ampla sobre a realidade vivenciada pelos moradores do bairro de Nova Caicó a partir do processo segregatório existente no referido espaço.

Palavtras-Chave: Caicó; Nova Caicó; Segregação socioespacial. 


\section{INTRODUÇÃO}

A população urbana no Brasil teve significativas mudanças no século XX, onde, em 1940, a população correspondia a 41 milhões de habitantes, ampliando para 93 milhões de habitantes em 1970 (CARVALHO, 2004). E no ano de 2017, segundo estimativas do Instituto Brasileiro de Geografia e Estatística - IBGE, a população brasileira correspondia a, aproximadamente, 208 milhões de habitantes.

Devido a esse crescimento expressivo da população, surgiram problemas nas cidades, uma vez que as mesmas não foram organizadas para receber tamanha população em um prazo de tempo tão curto. E, como consequência, os moradores de áreas segregadas das cidades possuíram um menor acesso a moradia, saúde e segurança (SILVA, 2016).

A partir do nascimento de aglomerados urbanos recentes, surge uma nova dinâmica urbano regional, destacando-se as cidades de médio porte, que interpretam uma relevante articulação entre as cidades grandes e as cidades pequenas.

Nesse sentido, Caicó se caracteriza como uma cidade intermediária de grande importância espacial no estado do Rio Grande do Norte, uma vez que é referência para as cidades circunvizinhas, interagindo ainda com as cidades de outros estados. Sua relevância pode ser destacada pelos aspectos econômicos, associado à formação do polo educacional de ensino superior, colaborando para o aumento da sua importância no cenário regional.

Assim, todos esses fatores beneficiam o crescimento urbano, com agentes econômicos, como o imobiliário, promovendo um processo especulativo do solo urbano. Partindo desse contexto, as áreas centrais passam a apresentar custos muito dispendiosos, o que torna a aquisição e ocupação inviável pela população em estado de vulnerabilidade social.

Mediante tais discussões, esta pesquisa buscou analisar os impactos da segregação socioespacial no bairro Nova Caicó, localizado na região Norte da Cidade de Caicó/RN. Para tanto, faz-se necessário estudar o histórico de ocupação desta área, bem como consultar as condições jurídicas fundiárias da mesma, além de abordar a infraestrutura e equipamentos urbanos presentes no assentamento.

Torna-se relevante destacar que o Bairro de Nova Caicó foi fundado há menos de 10 anos, a partir de políticas habitacionais direcionadas pelo Ministério das Cidades, numa parceria entre os poderes: municipal estadual e federal, objetivando fornecer moradia para famílias de baixa renda. Destaca-se ainda, que a construção das habitações na referida localidade foi advinda da existência de parcelas de solo com reduzido custo, as quais foram cedidas pela administração municipal caicoense, num terreno situado nas proximidades do Instituto Federal de Educação, Ciência e Tecnologia do Rio Grande do Norte - IFRN, tornando o futuro bairro de Nova Caicó como um "aglutinador espacial" entre o IFRN e o restante da cidade, numa evidente processo de apropriação urbana.

Desta forma, discutiremos o processo de segregação sócio espacial no bairro de Nova Caicó, a partir de seu crescimento habitacional, associado aos problemas de infraestrutura, destacando as questões socioeconômicas e as ações do poder público na localidade, em especial no que se refere ao funcionamento dos serviços públicos e privados.

\section{PROCEDIMENTOS METODOLÓGICOS}

No que se refere as procedimentos metodológicos, conforme afirma Gil (2007), a presente pesquisa se caracteriza como um estudo de caso, pois buscamos explorar situações reais cujos limites não estão claramente definidos, bem como preservar o caráter unitário do meio estudado e descrever a situação do contexto no qual está sendo realizada a investigação.

Assim, o presente estudo foi realizado no Bairro Nova Caicó, localizado na Cidade de Caicó/RN. Durante a sua execução, foram realizados estudos bibliográficos acerca da segregação socioespacial, onde a mesma foi discutida como uma problemática urbana e social, no qual HUGHES (2004) foi utilizado como relevante referencial teórico. Além disso, por conseguinte, abordou-se Caicó/RN, sendo utilizado MACÊDO (2003) como referência bibliográfica. Também foram utilizados os dados estatísticos advindos do Instituto Brasileiro de Geografia e Estatística - IBGE, para ampliar as discussões sobre a temática em questão. 
Posteriormente, realizaram-se visitas in loco e sendo executada uma pesquisa de levantamento de dados junto à população, num universo de 45 residências, para ter acesso às características socioeconômicas, bem como registros fotográficos do bairro. E, finalmente, a presente pesquisa foi redigida e está sendo apresentada em eventos regionais e nacionais.

\section{CARACTERIZAÇÃO ESPACIAL DE CAICó/RN}

A cidade de Caicó, de acordo com o Instituto Brasileiro de Geografia e Estatística - IBGE possui uma população estimada em 68. 222 habitantes no ano de 2017, e se encontra localizada na microrregião do Seridó Ocidental, sendo a mais populosa da Mesorregião Central Potiguar e a sétima mais populosa do estado do Rio Grande do Norte.

Essa cidade originou-se a partir da expansão da pecuária bovina, tornando-a destaque pelos seus produtos de origem bovina, como a carne de sol, o queijo e a manteiga da terra. Em meados do século XVIII há o fortalecimento da atividade algodoeira, a qual ganha destaque nacional e mundial durante o século XIX e XX (LIVRAMENTO, 1987).

Atualmente a cidade de Caicó é caracterizada por uma grande prestação de serviços e das atividades comerciais locais, estabelecendo dessa forma, importantes relações com as cidades circunvizinhas. Também há destaque no que se refere às questões religiosas da matriz católica apostólica Romana, uma vez em que a cidade é sede de uma das três dioceses existentes no Rio Grande do Norte, com Santana destacando-se como padroeira da cidade, ocorrendo no mês de julho a festa em sua homenagem, tombada como patrimônio imaterial brasileiro pelo Instituto do Patrimônio Histórico e Artístico Nacional - IPHAN. Além dessa festa de cunho religioso, ainda se destaca pelo carnaval que é o considerado um dos mais tradicionais do Nordeste, onde atrai turistas de vários pontos da referida região.

De acordo com as Regiões de Influência das Cidades - REGIC (IBGE, 2007), Caicó/RN é classificada como Centro Sub-regional A, um nível de grande importância para a rede urbana nordestina, visto que esses centros assumem funções de mediação entre os grandes centros urbanos e as pequenas cidades, sendo classificada, portanto, como uma cidade média ou intermediária.

Nesse contexto, Caicó é considerado como um grande polo educacional, existindo uma participação significativa do setor público na implementação de cursos de nível superior, com a presença da Universidade Federal do Rio Grande do Norte (UFRN), Universidade Estadual do Rio Grande do Norte (UERN), e o Instituto Federal de Educação, Ciência e Tecnologia do Rio Grande do Norte (IFRN), o qual também possui o ensino médio integralizado com a formação técnica.

Também se destaca a existência de instituições de ensino superior privadas, como a Universidade do Sul de Santa Catarina (UNISUL), Universidade Paulista (UNIP), Faculdade Católica Santa Teresinha (FCST), Universidade Potiguar (UNP), Universidade Norte do Paraná (UNOPAR). Todos esses fatores colaboram para que essa cidade se constitua como uma cidade média.

As cidades médias são valorizadas como fator de equilíbrio para as redes e hierarquias urbanas, bem como por exercer as funções de relação e intermediação com as grandes e pequenas cidades e com o meio rural, onde o papel de articulação e intermediação são fundamentais para a implantação, desenvolvimento e a expansão dos corredores de transporte e comunicações (DANTAS e CLEMENTINO, 2013 apud SILVA, 2016).

Diante desse quadro de dinâmicas econômicas consideráveis, associado a interesses e intencionalidades do capital no espaço caicoense, há processos como a especulação imobiliária, a partir da constituição de formas espaciais que valorizam o espaço, elevando os preços do meio habitacional nas regiões centrais, e, por conseguinte, a população de baixa renda acaba sendo segregada e marginalizada para as periferias da cidade, possuindo grande dificuldade no acesso de serviços públicos e privados, uma vez que há notáveis carências de infraestrutura para a população residente, aprofundando o processo de segregação socioespacial, como será aprofundado a seguir.

\section{SEGREGAÇÃO SOCIOESPACIAL}

Com as transformações urbanas advindas do processo de reprodução capitalista, associada a uma distribuição desigual de renda, e uma consequente desigualdade na distribuição dos serviços públicos, há um notório processo de segregação espacial. 
Segundo Carlos (1992), a paisagem urbana é constituída por um choque de contrastes, onde o espaço é produzido fundamentalmente de maneira desigual, e, logo, essa contradição será refletida no espaço. A autora explica que a população mais pobre parte em busca das áreas mais distantes, onde os terrenos são mais baratos, os quais não possuem infraestrutura, num processo de autoconstrução das moradias.

E esse fenômeno é aprofundado pela especulação imobiliária, onde a área central acaba por se tornar valorizada e a periferia tende a ser desvalorizada. Esse desenvolvimento antagônico de uma cidade capitalista, conduz a maioria dos moradores a serem excluídos de direitos básicos de trabalho, educação e saúde (HUGHES, 2004). Faz-se necessário complementar que:

\begin{abstract}
"a ausência da ação do Estado nas periferias foi uma marca recorrente da urbanização periférica, gerando uma estrutura urbana precária, com insuficientes equipamentos sociais (escolas e postos de saúde) e déficits de infraestrutura e de melhorias urbanas essenciais (como saneamento básico), fruto de uma ocupação desordenada que comprometeu a qualidade de vida, a mobilidade e o acesso da população aos serviços e ao mercado de trabalho." (HUGHES, 2004, p.75).
\end{abstract}

Em um sistema político-econômico contraditório, onde existem contrastes entre as formas espaciais e o modo de habitação, ampliam-se as restrições a infraestrutura, alimentação, educação, emprego, moradia, saúde e aos demais serviços públicos, além do escasso acesso a equipamento técnicos de produção, lazer, diversão e cultura. É notório que os lotes e os terrenos urbano nas principais localidades de uma cidade capitalista custa caro e isso gera uma segregação, que afasta, dessa forma, a população carente, a qual fica a margem de todos esses benefícios.

Colocaram o morador pobre aspirante a uma habitação pelos órgãos governamentais em contato com o clientelismo na distribuição de moradias, em longas filas de espera, sujeito ao preenchimento de cadastro em que desfilam seu baixo salário, o número de dependentes, a falta de residência condigna, enfim, as condições que o encaixam como membro dessa vasta categoria 'população de baixa-renda' E continua. Como opção fora da máquina governamental, ocupam favelas e cortiços, moradias precárias das quais poderiam ser expulsos por políticas habitacionais tomadas à sua revelia (...) (CALIXT0, 2008, p.81)

E isso é visto claramente no bairro Nova Caicó, onde não há os serviços basilares de educação e saúde, associado a inexistência de equipamentos técnicos de produção, lazer, diversão e cultura, corroborando, assim, a existência de um notório processo de segregação socioespacial, como será mais bem visualizado a seguir.

\title{
5 REFLETINDO O PROCESSO SEGREGATÓRIO NO BAIRRO NOVA CAICÓ
}

No presente tópico, serão aprofundadas as discussões relativas ao processo segregatório do bairro Nova Caicó, situado na porção norte de Caicó/RN, como destacado na figura 01, a seguir. 0 bairro teve início com a construção de residências em parceria do poder público municipal com o Governo Federal, no ano de 2007. 
Figura 01: Mapa de localização do bairro Nova Caicó, no município de Caicó-RN

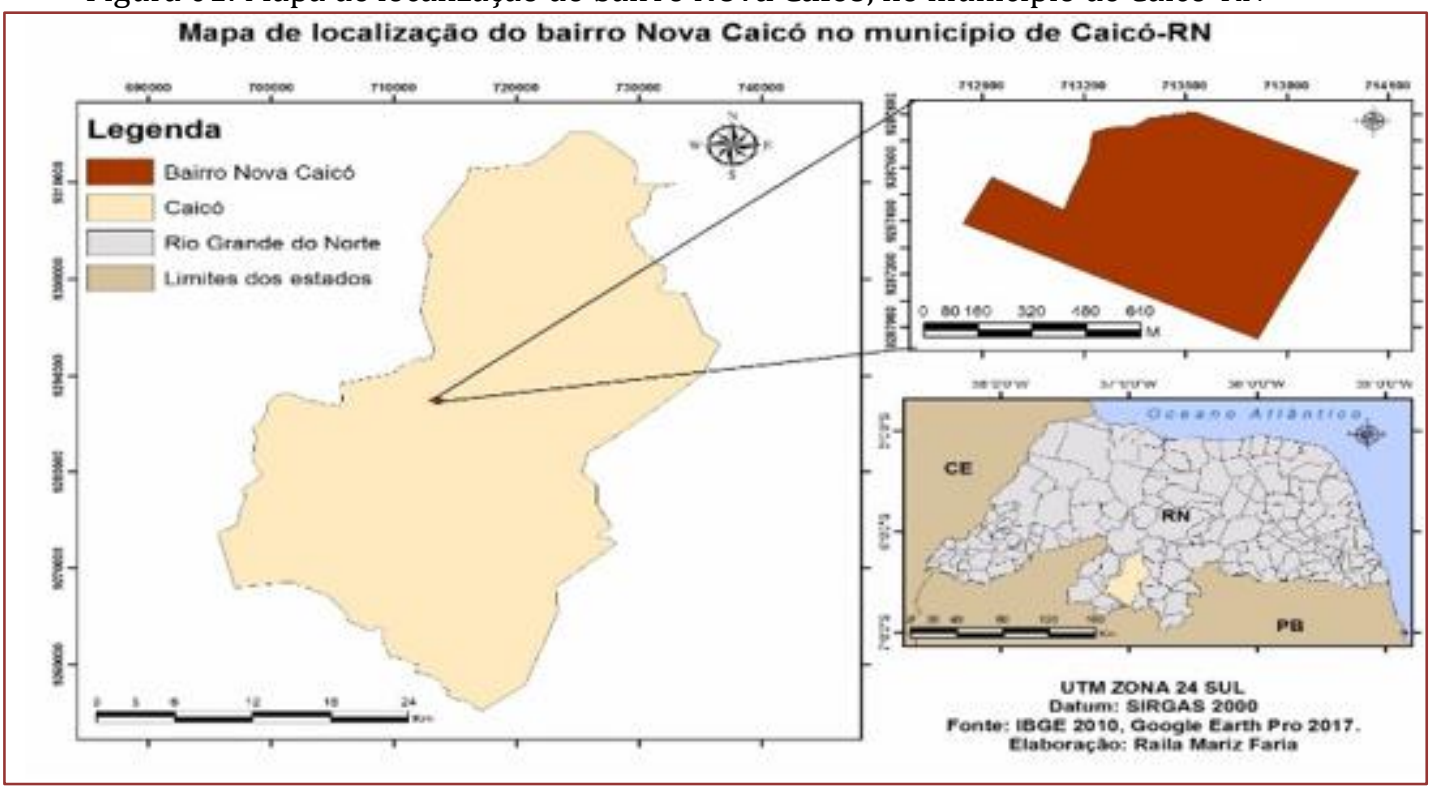

Fonte: Raila Mariz Faria, 2017.

Entretanto, a construção do bairro não foi acompanhada de uma infraestrutura básica, como é perceptível a partir da pesquisa de campo. A comunidade aponta problemas como a ausência de segurança, de recursos hídricos, o descaso do poder público na coleta de lixo, muito embora possua coleta de esgoto. Também se destaca a ausência da pavimentação em todas as ruas, além de não existir locais adequados para o lazer, à diversão e a cultura, embora possua uma unidade do IFRN situada no bairro, mas com acesso restrito a comunidade não integrante da referida instituição de ensino.

Além disso, a unidade de saúde possui escassez de medicamentos, os quais não são repassados em quantidade suficiente para suprir as necessidades da população, embora possua atendimento médico com frequência.

Quanto à coleta de lixo, a mesma não ocorre de modo frequente, numa problemática correlacionada com o desenvolvimento das cidades, uma vez que a ampliação da população, associada ao consumo desenfreado, incentivado pelas inovações tecnológicas, podem causar danos ao homem quanto ao meio ambiente, uma vez que há notória dispersão de insetos e animais, que podem causar graves doenças, como dengue e leptospirose.

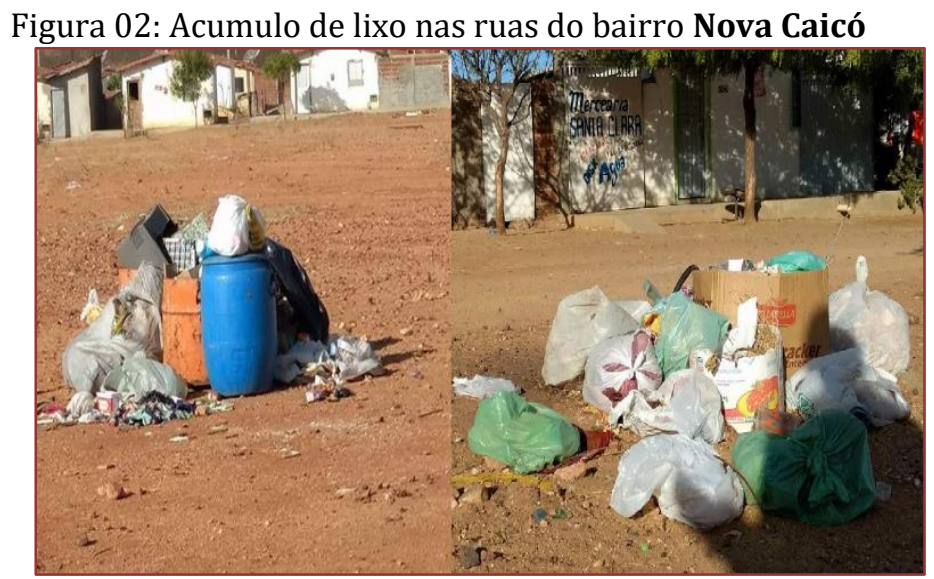

Fonte: Lucas Henrique Lima Alves, 2017.

Assim, evidenciou-se, como observado na figura 02, que o bairro possui grande acumulo de lixo nas ruas, uma vez que, segundo os moradores entrevistados, a coleta de lixo é feita de maneira irregular, chegando a ficar um mês sem ocorrer. 
Porém, a situação é atenuada com a existência da coleta seletiva, realizada pelos catadores que residem no próprio bairro, auxiliando na redução do lixo acumulado nas ruas do bairro, como pode ser visto na Figura 03. Além disso, a coleta e comercialização de materiais recicláveis se tornam, para muitos, a única forma de garantir o sustento da família.

Figura 3: Catador de lixo e os materiais recicláveis

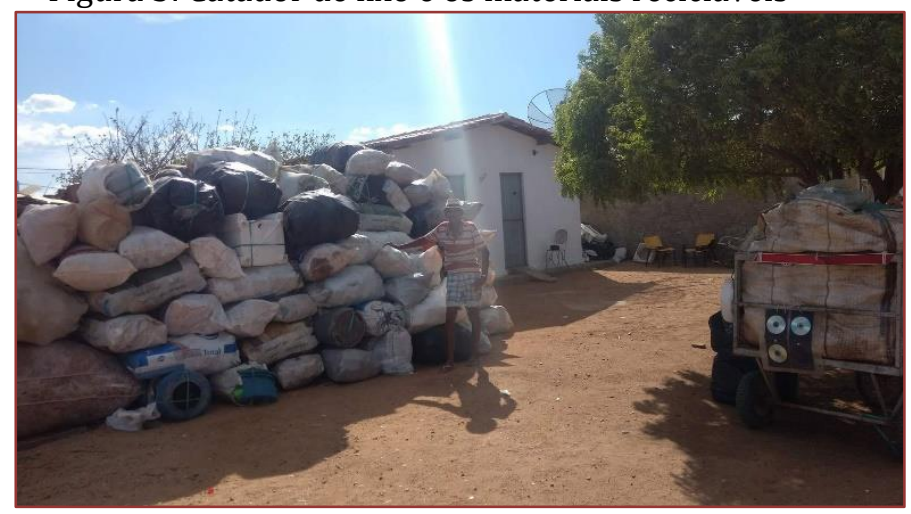

Fonte: Lucas Henrique Lima Alves, 2017.

Também ficou evidente que o bairro possui escasso acesso a educação, uma vez que há apenas a Creche Oscarina Torres, a qual atende ao ensino infantil, com o aluno da comunidade necessitando ir a outros bairros para ter acesso à educação. Igualmente, há a problemática da saúde, uma vez que a unidade básica de saúde Dr. Dirceu Pereira Fontes, destacada na figura 04, não possui muitos dos insumos básicos para assistir a população.

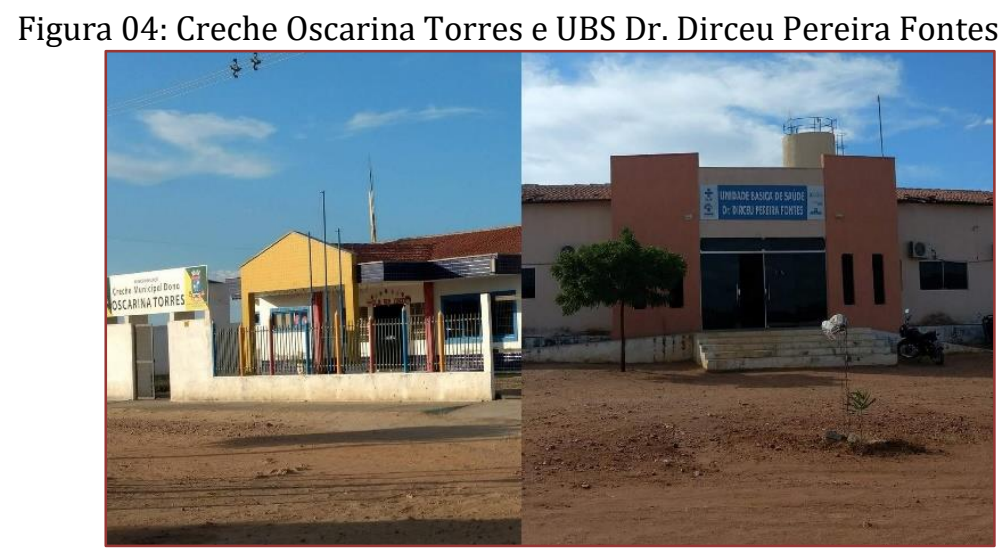

Fonte: Lucas Henrique Lima Alves, 2017

Assim, fica evidente que o bairro de Nova Caicó segue a lógica capitalista onde a população de baixa renda é marginalizada para as periferias da cidade, possuindo grande dificuldade no acesso de serviços públicos e privados, associada a uma baixa infraestrutura para a população residente.

E também como consequência dos processos segregatório, amplia-se a criminalidade, advinda de fatores estruturais, como o status econômico, mobilidade residencial, além da desestrutura familiar e urbanização (SAMPSON,1997 apud CERQUEIRA e LOBÃO, 2004).

\section{CONSIDERAÇÕES FINAIS}

A partir da pesquisa realizada, evidencia-se que a segregação socioespacial, problemática eminente no modo capitalista de produção, consequência de uma reprodução desigual e contraditória deste sistema econômico, conduz a uma ampliação na escassez de políticas públicas e sociais mais abrangentes e eficazes. 
Embora ocorram avanços, como os projetos sociais que visam beneficiar a população segregada com a distribuição de moradias e a consequente criação e fundação de novos conjuntos habitacionais, a situação da população de baixa renda continua precária, devido ao descaso e falta de planejamento do poder público advindos de um processo segregatório, o qual só será minimizado com políticas públicas de educação, saúde e constituição de uma infraestrutura plena nestes novos pontos do espaço urbano.

Portanto, ao compreender e informar sobre a dinâmica do bairro Nova Caicó e seu atual processo de segregação socioespacial, a partir de diálogos com a população local, evidencia-se que esta problemática só será minimizada com políticas públicas que efetivamente possibilitem a esta população maiores e melhores oportunidades de crescimento social e intelectual, algo ainda distante num sistema tão desigual como o capitalista.

\section{REFERÊNCIAS}

[1] Andrade, Inêz Barcellos de; Lima, Maria Cristina Miranda. Manual para elaboração e apresentação de trabalhos científicos: artigo científico. Faculdade de Medicina de Campos, Campos dos Goytacazes - RJ, 2007

[2] Brasil. Instituto Brasileiro de Geografia e Estatística. Cidades. 2017. Disponível em: < https://cidades.ibge.gov.br/brasil/rn/caico/panorama>. Acesso em: 22 nov. 2017.

[3] Brasil. Instituto Brasileiro de Geografia e Estatística. Estimativas da população residente no Brasil e unidades da Federação com data de referência em 1o de julho de 2017. Disponível em: < https://ww2.ibge.gov.br/apps/populacao/projecao/>. Acesso em: 23 nov. 2017.

[4] Brasil. Instituto Brasileiro de Geografia e Estatística. Regiões de Influência das Cidades. 2007. Disponível em: <http://www.mma.gov.br/estruturas/PZEE/_arquivos/regic_28.pdf>. Acesso em: 22 nov. 2017.

[5] Brasil. Instituto do Patrimônio Histórico e Artístico Nacional. Festa de Sant'ana. Disponível em: < http://portal.iphan.gov.br/rn/galeria>. Acesso em: 19 nov. 2017.

[6] Carlos, Ana Fani Alessandri. A cidade. 8 ed. São Paulo. Pinsk, 1992.

[7] Carvalho, José Alberto Magno de. Crescimento populacional e estrutura demográfica no Brasil. Belo Horizonte. UFMG. 2004

[8] Calixto, Maria José Martinelli Silva. O espaço urbano em redefinição: cortes e recortes para a análise dos entremeios da cidade. Dourados. Ufgd, 2008.

[9] Cerqueira, Daniel; Lobão, Waldir. Determinantes de criminalidade: arcabouços teóricos e resultados empíricos. Revista de Ciências Sociais, Rio de Janeiro, Vol. 47, no 2, 2004, pp. 233 a 269.

[10] Clementino, Maria do Livramento Miranda. 0 maquinista do algodão e o capital comercial. Natal, Edufrn, 1987.

[11] Gil, A. C. Como elaborar projetos de pesquisa. 4ed. São Paulo: Atlas, 2009.

[12] Harvey, D. A Produção Capitalista do Espaço. São Paulo: Anablume, 2005.

[13] Hughes, Pedro Javier Aguerre; Segregação socioespacial e violência na cidade de São Paulo: referências para a formulação de políticas públicas, 2004.

[14] Macêdo, Muirakytan K. de. Caicó: uma viagem pela memória seridoense. Natal. Sebrae, 2003.

[15] Silva, M. M. N. et al. Segregação socioespacial: os impactos das desigualdades sociais frente a formação e ocupação do espaço urbano. Revista Monografias Ambientais - Remoa v. 15, n.1, jan-abr. 2016, p.256-263 Revista do Centro de Ciências Naturais e Exatas - UFSM, Santa Maria, RS.

[16] Santos, Antonio Raimundo dos. Metodologia cientifica: a construção do conhecimento. Rio de Janeiro. Lamparina, 2007. 


\section{Capítulo 13}

\section{Posições do cavado equatorial e da faixa de máxima TSM no Atlântico Tropical}

\section{Jamilly Leite Dias \\ José Ivaldo Barbosa de Brito}

Resumo: Este trabalho apresenta um estudo do monitoramento das variáveis envolvidas na caracterização da Zona de Convergência Intertropical (ZCIT) no oceano Atlântico Tropical, entre as latitudes de $17,25^{\circ} \mathrm{N}$ a $5,25^{\circ} \mathrm{S}$ e das longitudes de $40^{\circ} \mathrm{W}$ a $20^{\circ} \mathrm{W}$, tendo como objetivo principal determinar a variabilidade interanual em pêntadas do posicionamento latitudinal do cavado equatorial e da faixa de máxima TSM no Atlântico Tropical, que são informações úteis no monitoramento da posição da ZCIT, que por sua vez é determinante para a qualidade da estação chuvosa do norte do Nordeste Brasileiro. Foram analisados dados médios das posições latitudinais de Temperatura da Superfície do Mar (TSM) e Pressão ao Nível Médio do Mar (PNMM), onde foram extraídos das reanálises nos horários de 3 UTC e 15 UTC obtidos do ERA-Interim, ECMWF (European Centre for Medium-Range Weather Forecast), com resolução espacial de $0,75^{\circ} \times 0,75^{\circ}$. Os dados utilizados referem-se ao período de $1^{\circ}$ de janeiro de 1997 a 31 dezembro de 2016. Os resultados indicaram que a faixa de máxima TSM concentrou-se mais ao sul em média do que o cavado equatorial. Essas variáveis são determinantes para a posição laditudinal da ZCIT, e trabalham em conjunto, mas não na mesma latitude.

Palavras-chave: Cavado equatorial, máxima TSM, Atlântico Tropical. 


\section{INTRODUÇÃO}

A variabilidade pluviométrica sobre o Nordeste Brasileiro é um dos fatores que registra as ocorrências das secas, e além de ser um problema climático, gera grandes problemas sociais e econômicos para a região e no país. Pois com a falta de chuvas e baixo índice pluviométrico, tornase difícil o desenvolvimento da agricultura e criação de animais, resultando a falta de recursos econômicos. Desta forma, a variabilidade interanual da precipitação nessa região está associada a variações de temperatura da superfície do mar (TSM) sobre os oceanos tropicais, as quais afetam a posição e a intensidade da Zona de Convergência Intertropical (ZCIT) sobre o Oceano Atlântico, modulando as chuvas sobre Norte do Nordeste do Brasileiro (NNEB) (Nobre, 2000).

Formada a partir da interação entre a confluência dos ventos alísios, a região do cavado equatorial, as áreas de máxima TSM e de máxima convergência de massa (Uvo, 1989), a ZCIT influencia nas precipitações observadas sobre os continentes africano, americano e asiático (Ferreira, 1996, Rosa e Silva, 2016). Este sistema migra durante o ano entre os Hemisférios Norte (HN) e Sul (HS). Embora o curso anual da ZCIT seja bem conhecido e muito estudado, sua posição é bastante variável em escalas de tempo mensal a interanual, o que contribui para a grande variabilidade espacial e temporal da precipitação no NNEB (Uvo, 1999). A ZCIT é a região de baixa pressão à superfície localizada em torno do equador, que apresenta, numa estreita faixa, máximos de nebulosidade e precipitação, e para onde convergem os ventos alísios de nordeste do $\mathrm{HN}$ e de sudeste do HS.

Como a ZCIT é mais predominante sobre os oceanos, dessa maneira, a faixa de máxima TSM no Atlântico é um dos fatores determinantes na posição e intensidade da ZCIT, pois geralmente está situada sobre ou próximo às altas TSMs. Hastenrath e Heller (1977) também consideram o Cavado Equatorial como representativo da ZCIT. A permanência da ZCIT em torno de suas posições mais ao sul é o fator mais importante na determinação da estação chuvosa no NNEB, pois define a duração da estação chuvosa (Nobre e Uvo, 1989).

Diante disto, o objetivo deste trabalho é determinar a variabilidade interanual em pêntadas do posicionamento latitudinal do cavado equatorial e da faixa de máxima TSM no Atlântico Tropical, que são informações úteis no monitoramento da posição da ZCIT, que por sua vez é determinante para a qualidade da estação chuvosa do norte do Nordeste Brasileiro.

\section{METODOLOGIA}

Dados das 3UTC e 15UTC de temperatura da superfície do mar e pressão ao nível médio do mar (PNMM) foram utilizados para a realização deste trabalho. Estes dados de reanálises foram obtidos do Centro Europeu de Previsão de Tempo (ECMWF), também chamado de "ERA-Interim", estando em pontos de grade de $0,75^{\circ}$ x $0,75^{\circ}$ para o período de janeiro de 1997 a dezembro de 2016. Utilizou-se o software Grid Analysis and Display System (GrADS) na conversão dos dados de reanálises das variáveis para o formato txt (ASCII). Calculou-se a média diária dos 2 horários e em seguida as pêntadas (dada pela média de cinco dias) das variáveis anualmente resultando em 73 pêntadas por ano e logo depois se selecionou os pontos de longitude e latitude para estudo. A área de estudo escolhida para identificar e analisar a zona de máxima TSM e as posições do Cavado Equatorial abrange um recorte sobre o Oceano Atlântico Tropical, compreendida entre $17,25^{\circ} \mathrm{N}$ à $5,25^{\circ} \mathrm{S}$.

Após obter os dados pentadais, que foram organizadas em planilhas no excel por guias para cada longitude, foram extraídos os valores máximos de TSM e mínimos de PNMM, para estimar as suas respectivas posições. Esses valores também foram usados para compreender a variabilidade latitudinal sazonalmente durante seus ciclos anuais, uma vez que a TSM é um dos fatores determinantes na posição e intensidade da ZCIT no oceano, e dessa maneira é de extrema importância à determinação da faixa de máxima TSM, pois a ZCIT geralmente está situada sobre ou próximo às TSM mais elevadas. Águas oceânicas mais quentes (frias) no Atlântico Tropical Norte e mais fria (quentes) no Atlântico Tropical Sul (padrão de dipolo no Atlântico Tropical) estão associadas com anos secos (chuvosos) no Nordeste. O mesmo ocorre para PNMM, com valores mínimos dos campos analisados para determinar a posição do cavado equatorial.

Para TSM na longitude de $40^{\circ} \mathrm{W}$, considerou-se a série de dados analisados até a latitude de 2,25으, devido ao longo desta longitude ser localizado o continente da costa do nordeste brasileiro, (resultando em ausência de dados de TSM), diferentemente da longitude de $30^{\circ} \mathrm{W}$, (correspondente 
à região central do Oceano Atlântico Tropical) como mostrado em (Chiang et al., 2002), que a longitude $27,5^{\circ} \mathrm{W}$ utilizada em seu trabalho representa melhor a estrutura da ZCIT, ao diminuir a influência da atividade convectiva transiente dos continentes africano e sul-americano. Considerado estes pontos importantes citados pelos autores, entretanto, como o objetivo deste trabalho é a influência da ZCIT sobre o Nordeste, foram escolhidas as longitudes de $40^{\circ} \mathrm{W}$ e $30^{\circ} \mathrm{W}$, a primeira passa pelo Nordeste e a segunda está próximo do centro do Atlântico.

De posse destas informações foram elaborados gráficos das posições latitudinais de máxima TSM e mínima PNMM de cada pêntada, de janeiro de 1997 a dezembro de 2016, totalizando 1460 pêntadas. Como se torna inconveniente plotar todas estas pêntadas em um único gráfico. Foram usados três períodos (1997-2003, 2004-2010, 2011-2016) em escalas de tempo de dois em dois meses para melhor representar as figuras devido à série longa de dados.

\section{RESULTADOS E DISCUSSÃO}

De acordo com o trabalho de Melo et al. (2002) a variabilidade diária da posição climatológica da ZCIT é máxima durante o período chuvoso no setor NNEB, para a longitude de $35^{\circ} \mathrm{W}$, como mostrada nas Figuras $1((\mathrm{~d}, \mathrm{e}, \mathrm{f}))$, porém, resultado semelhante foi observado em $40^{\circ} \mathrm{W}$ Figuras 1 $((a, b, c)), c o m$ algumas diferenças. Observou-se que a variabilidade pentadal da posição máxima das TSM é maior nos meses em que a ZCIT atinge posições extremas tanto ao norte como ao sul comparativamente aos meses de transição. Este é um resultante importante, pois nos extremos têm-se as condições limites, enquanto nas interfases têm-se um caminho livre para a ZCIT oscilar. Os valores da posição da TSM ao sul do equador foram observados particularmente na longitude $30^{\circ} \mathrm{W}$ (região central do Oceano Atlântico Tropical), nos meses de fevereiro e meses de outono do hemisfério sul como (março e abril), enquanto as posições mais ao norte em ambas as longitudes foram observadas em agosto, setembro, outubro durante o outono do hemisfério norte. Vários estudos mostram que anomalias da TSM nos Oceanos Pacífico e Atlântico tropicais afetam o posicionamento latitudinal da ZCIT e, em particular, da ZCIT Atlântica (De Souza et al., 2005; Gu e Adler, 2009). Constatou-se que comportamento pentadal anual do máximo valor da TSM em média foram entre $9^{\circ} \mathrm{N}$ à $2,25^{\circ} \mathrm{S}$ para longitude de $40^{\circ} \mathrm{W}$. E para $30^{\circ} \mathrm{W}$, aproximadamente entre $15^{\circ} \mathrm{N}$ à $5,25^{\circ} \mathrm{S}$, atingindo seus picos máximos e mínimos, correspondente. Nota-se que na longitude de $30^{\circ} \mathrm{W}$ observou-se uma variabilidade mais coerente, comparada com a de $40^{\circ} \mathrm{W}$. Conforme mostrada a literatura (Kousky, 1988), que no sentido longitudinal, a ZCIT é notadamente mais intensa na região central do Atlântico, do que perto da costa da América do Sul de meados de julho até meados de dezembro. 
Figura 1. Posições de máximas TSM, considerando os períodos: 1997-2003, 2004-2010, 2011-2016 para as longitudes (a), (b) e (c) $40^{\circ} \mathrm{W}$, (d), (e) e (f) $30^{\circ} \mathrm{W}$.

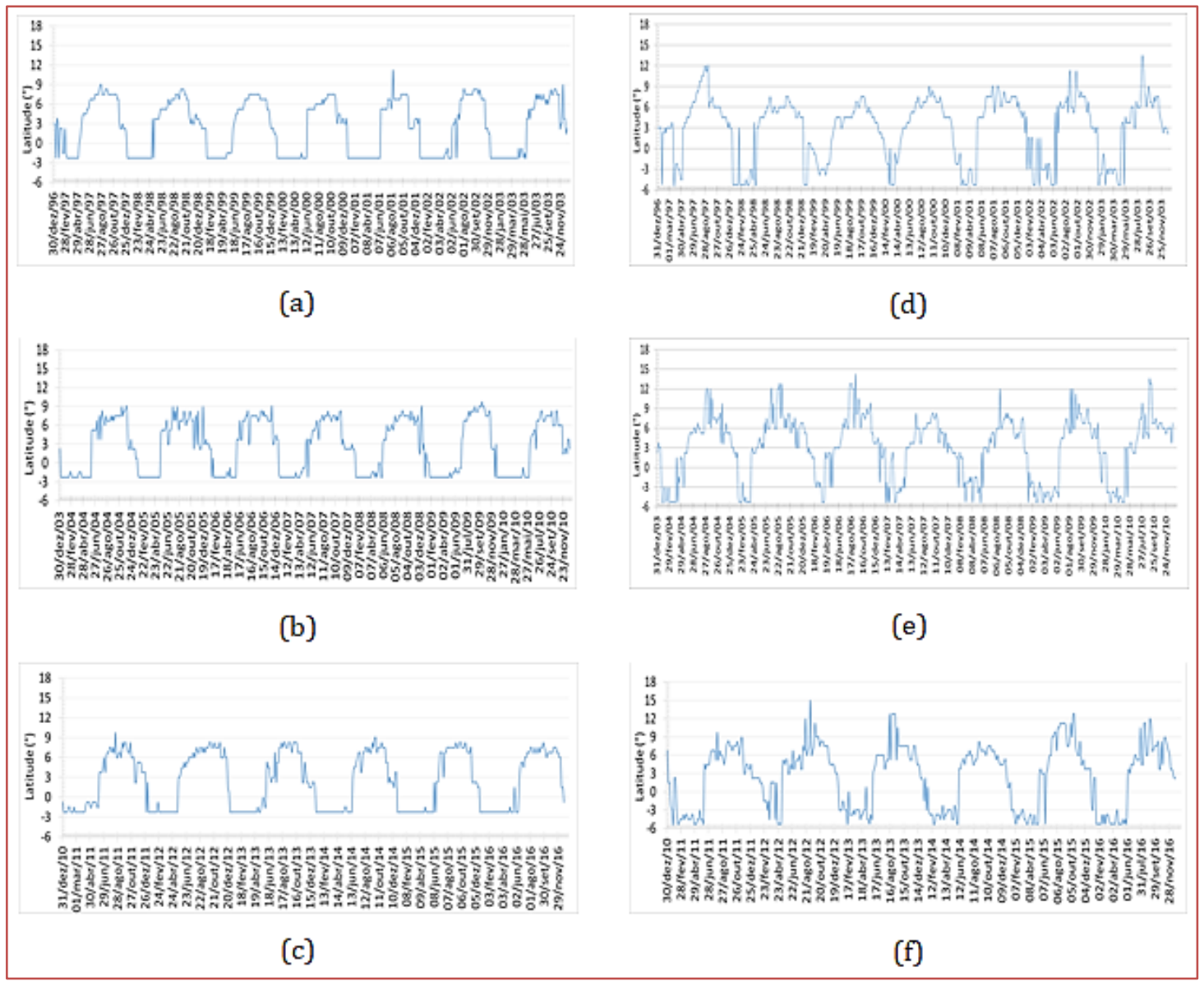

0 conjunto de Figuras 2 se refere às posições latitudinais de mínimos valores de PNMM para as longitudes de $40^{\circ} \mathrm{W}$ e $30^{\circ} \mathrm{W}$. 0 comportamento da variabilidade sazonal de PNMM foi semelhante ao mostrado na Figura 1. Na figura 2 (a) observa-se que latitudes com mínimos valores de PNMM ocorreu no período de novembro/97 atingindo a máxima latitude sul com 3,75으 $\mathrm{S}$, e máxima posição latitudinal de $17,25^{\circ} \mathrm{N}$ em 12 de outubro/99. De 25 de novembro/2002 a 20 de dezembro/2002 observou-se poucas oscilações da ZCIT, até período em que a ZCIT se encontra mais ao sul do equador. Observou-se que os picos latitudinais de valores mínimos de PNMM para o $\mathrm{HN}$, foram registrados a partir de setembro, outubro, e novembro para ambas longitudes $\left(30^{\circ} \mathrm{W}\right.$, $40^{\circ} \mathrm{W}$ ). Porém na longitude de $30^{\circ} \mathrm{W}$ como observado na figura 1 (d) a máxima latitude foi de $5,25^{\circ} \mathrm{S}$, que diferente de $40^{\circ} \mathrm{W}$, atingiu a posição de $\left(1,5^{\circ}\right)$ a mais, com um alcance mais ao sul. 
Figura 2. Posições de mínimos PNMM, considerando os períodos: 1997-2003, 2004-2010, 2011 2016 para as longitudes (a), (b) e (c) $40^{\circ} \mathrm{W}$, (d), (e) e (f) $30^{\circ} \mathrm{W}$.

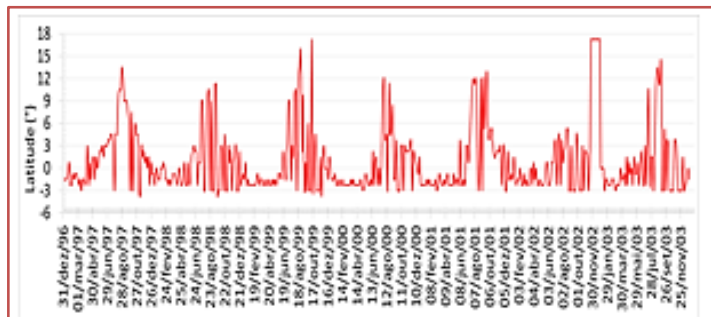

(a)

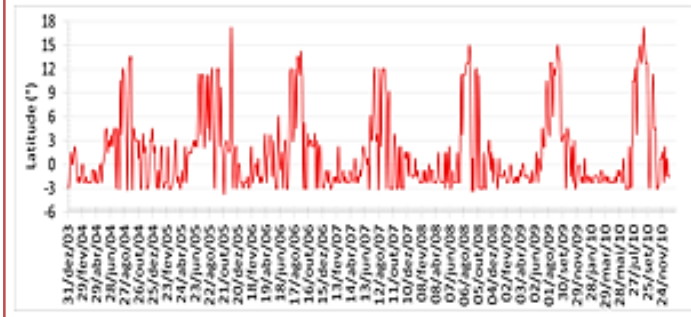

(b)

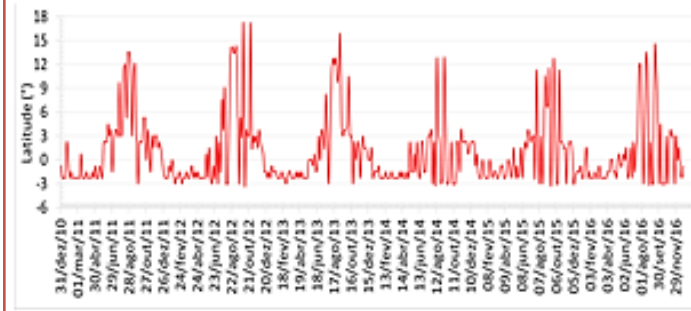

(c)

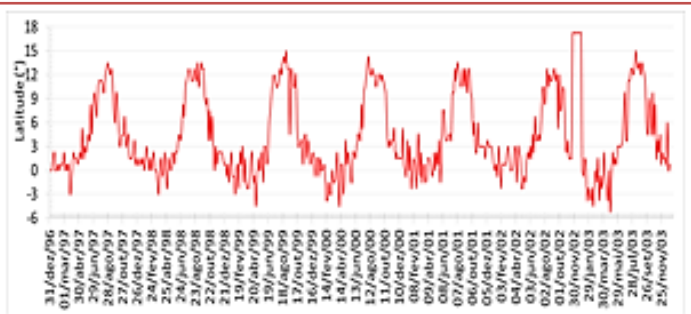

(d)

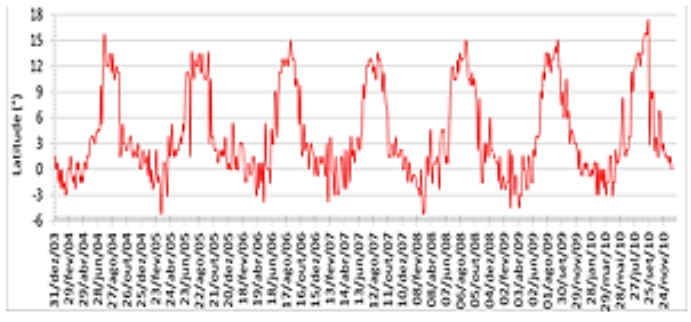

(e)

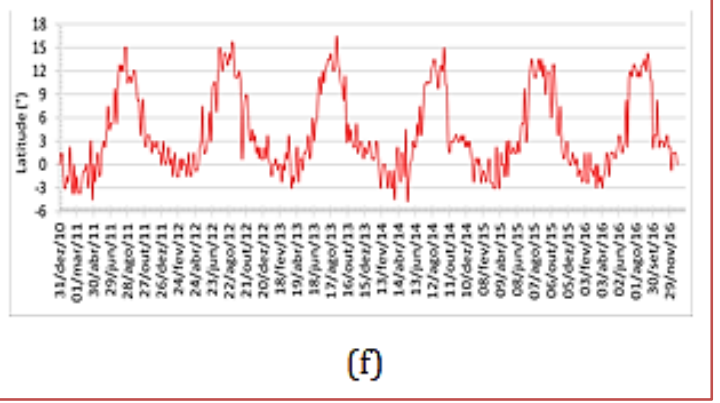

\section{CONCLUSÕES}

Este trabalho abordou o comportamento latitudinal, sazonal e interanual das características da ZCIT e logo pôde se dizer que a faixa de máxima TSM concentrou-se mais ao sul em média do que o cavado equatorial. Essas variáveis são determinantes para a posição laditudinal da ZCIT, e trabalham em conjunto, mas não na mesma latitude.

Com os resultados encontrados, constatou-se que a longitude de $30^{\circ} \mathrm{W}$ verificou-se uma maior variabilidade interanual em pêntadas do posicionamento latitudinal do cavado equatorial e da faixa de máxima TSM no Atlântico Tropical que é um dos fatores determinante para a qualidade da estação chuvosa do norte do Nordeste Brasileiro. Diante destas conclusões, a pesquisa deverá ser continuada objetivando o acompanhamento do comportamento latitudinal, sazonal e interanual de outras zonas que também são características da ZCIT.

\section{REFERÊNCIAS}

[1] DE SOUZA, E. B.; KAYANO M. T.; AMBRIZZI, T. Intraseasonal and submonthly variability over the eastern Amazon and Northeast Brazil during the autumn rainy season. Theoretical and Applied Climatology, $\mathrm{v}$. 81, p. 177-191, 2005.

[2] FERREIRA, N. S. Zona de Convergência Intertropical. Climanálise. MCT/INPE. Edição Especial de 10 anos. Cachoeira Paulista, SP. 1996. 235 p.

[3] GU, G.; ADLER, R. F. Interannual variability of boreal summer rainfall in the equatorial Atlantic. International Journal of Climatology, v. 29, p. 175-184, 2009.

[4] HASTENRATH S.; HELLER. L. Dynamics of climatic hazards in Northeast Brazil. Quarterly Journal of the Royal Meteorological Society, v. 103, n. 435, p. 77-92, 1977. 
[5] KOUSKY, V. E. Pentad outgoing longwave radiation climatology for the South American sector. Revista Brasileira de Meteorologia, v. 3, p. 217-231, 1988.

[6] MELO, A. B. C., NOBRE, P., MELO, M. L. D., SANTANA, S. C., 2002: Estudo Climatológico da Posição da ZCIT no Atlântico Equatorial e sua Influência sobre o Nordeste do Brasil. In: Congresso Brasileiro de Meteorologia, 12, 2002, Foz do Iguaçu. Anais Foz do Iguaçu, SBMET, 2012.

[7] NOBRE ET AL. Oscilações Intrasazonais nos Trópicos e Variações Pluviométricas sobre o Nordeste do Brasil em 1999. In: Congresso Brasileiro de Meteorologia. 11, Rio de Janeiro. 2000. Anais. Rio de Janeiro: SMET, 2000.

[8] ROSA, M. B.; SILVA, L. T. Alguns Aspectos Climatológicos da ZCIT sobre o Atlântico. Climanálise Edição comemorativa de 30 ano, 2016.

[9] UVO, C. R. B.; NOBRE, C. A. A Zona de Convergência Intertropical (ZCIT) e a precipitação no norte do Nordeste do Brasil. Parte I: A posição da ZCIT no Atlântico Equatorial. Climanálise, v. 4, n. 7, p. 34-40, 1989.

[10] UVO, C. B. A Zona de Convergência Intertropical (ZCIT) e sua relação com a precipitação na Região Norte do Nordeste Brasileiro. Dissertação de Mestrado em Meteorologia, INPE. São José dos Campos, SP. 1989. 


\section{Capítulo 14}

A influência do uso do solo no conforto humano: Uma perspectiva urbana e rural em Caicó, município de clima semiarido quente do Nordeste Brasileiro.

Artur Ismael Viana de Medeiros

Cristiano Saulo de Morais

Aline Soares da Silva

Raila Mariz Faria

Rebecca Luna Lucena

Resumo: Os estudos de climatologia ganham cada vez mais importância na contemporaneidade mediante a evidente evolução da dinâmica antrópica sobre o ambiente, desta forma, evidencia-se a necessidade da realização de estudos da influência de aspectos humanos sobre o clima local. Portanto, nota-se a ação do homem como um dos principais fatores que determinam o caráter e função do solo, fator esse que, a nível local, aparece como de maior influência que os demais fatores naturais em conjunto. Nessa perspectiva, esse trabalho traz um estudo sobre a influência do uso do solo no conforto térmico humano de uma cidade de clima quente e seco do semiárido potiguar do Nordeste brasileiro, objetivando mostrar o quadro higrotérmico vivenciado numa perspectiva urbana e rural, caracterizando os contrastes proporcionados ao clima local mediante aspectos do processo de urbanização. Desta forma, a presente pesquisa se deu através da coleta e análise de dados higrotérmicos de 2 pontos distintos, um localizado no perímetro urbano e outro na zona rural do município de Caicó, no estado do Rio Grande do Norte. Em cada ponto foi instalado um termohigrômetro automático que fez o registro de dados horários das variáveis temperatura do ar $\left({ }^{\circ} \mathrm{C}\right)$ e umidade relativa do ar (\%), durante um período de coleta de 10 meses entre os anos de 2016 e 2017. 0 ponto 1 é uma rua aberta intensamente urbanizada na zona central da cidade, exposta a alta insolação, caracterizada por uma via asfaltada de constante movimentação; e o ponto 2 está localizado na zona rural do município, caracterizada por pouca modificação ambiental, com solo exposto e intensa cobertura vegetal tanto gramínea como arbórea nas adjacências e fica próxima a um corpo hídrico de tipo açude. Os dados obtidos foram processados, destacando suas médias, amplitude, valores máximos e mínimos absolutos e valores maiores que $40^{\circ} \mathrm{C}$. Partindo de uma função comparativa, notou-se no âmbito das médias uma diferença de $1,5^{\circ} \mathrm{C}$ entre os pontos: 0 Ponto 1 com média de $30,9^{\circ} \mathrm{C}$ e o Ponto 2 com média de $29,4^{\circ} \mathrm{C}$. Levando-se em comparação dados de valores máximos absolutos, o ponto 1 apresentou o valor de 43,5C e o ponto 2 apresentou valor de $41,1^{\circ} \mathrm{C}$, destacando uma diferença para suas máximas de $2,4^{\circ} \mathrm{C}$. Também comparando as temperaturas mínimas absolutas, o ponto 1 apresentou valor de temperatura de 20,9ㄷ e o ponto 2 , $19,9^{\circ} \mathrm{C}$, destacando assim uma diferença de exatamente $1^{\circ} \mathrm{C}$ entre eles. Para esta análise, comparouse também valores maiores que $40^{\circ} \mathrm{C}$ entre os pontos 1 e 2 , totalizando uma diferença de 129 valores, com resultados 33x maiores entre os pontos, sendo o ponto 1 o detentor dos maiores valores. Portanto, é visto que as atividades humanas não planejadas e efetuadas por meio de medidas inconsequentes, como ocupação inadequada do solo e alteração da vegetação nativa para fins urbanos, não considerando aspectos naturais locais, consequentemente modificam o microclima local, levando assim, inevitavelmente, junto com a modificação das propriedades do solo, a modificação também da atmosfera, intensificando o seu aquecimento. 


\section{INTRODUÇÃO}

Os estudos de climatologia ganham cada vez mais importância na contemporaneidade mediante a evidente evolução da dinâmica e ação antrópica sobre o ambiente, desta forma, evidencia-se a necessidade da realização de estudos da influência de aspectos humanos sobre o clima local, destacando a fundamental ação do homem, por meio de construções civis, não impondo a relação necessária com as condições locais, culminando em ações hostis, projetando alterações significativas nas variáveis ambientais e consequente alteração também do microclima local, condicionando assim, a consequências de grande amplitude referentes ao conforto térmico em ambientes urbanos.

Os estudos de conforto térmico tratam-se de análises referente a variáveis atmosféricas que buscam como resultados o estabelecimento de condições necessárias para construção de ambientes adequados para o bem estar e ocupação humana. Desta forma, tais estudos baseiam-se em fatores antrópicos, bem como: a satisfação, performance e conservação de energia do homem; fatores estes que estão diretamente ligados a interação homem e ambiente. Portanto, nota-se a ação antrópica como um dos principais fatores que determinam o caráter e função do solo, fator esse que, a nível local, aparece como de maior influência que os demais fatores naturais em conjunto.

Portanto para este trabalho se traz um estudo sobre a influência e uso da terra no conforto térmico humano de uma cidade de clima quente do semiárido potiguar do nordeste brasileiro, objetivando assim, mostrar o quadro higrotérmico vivenciado numa perspectiva urbana e rural, caracterizando os contrastes proporcionados ao clima local mediante aspectos do processo de urbanização.

Desta forma, através de um trabalho de coleta, análise e interpretação de algumas variáveis meteorológicas no município de Caicó, no estado do Rio Grande do Norte, por meio da relação com aspectos físicos naturais e antrópicos das paisagens em estudo, se pode constatar a influência da modificação antrópica no microclima local, apontando-se a partir destes, possíveis ações que busquem as melhores condições de arrefecimento e bem estar social e biológico para a população local.

\section{A IMPORTÂNCIA DOS ESTUDOS SOBRE CLIMA URBANO E CONFORTO TÉRMICO}

A importância do estudo da climatologia, mais precisamente na área do clima urbano, visando maior conhecimento para o planejamento das cidades é quase que indispensável, pois as modificações do solo urbano a partir da construção civil, na verticalização de edifícios, cobertura e impermeabilização da camada do solo com asfalto e retirada da vegetação, traz ao ambiente, alterações climáticas claras, na temperatura e umidade relativa do ar, assim formando uma espécie de campo de condutividade térmica, com maior temperatura ao centro, amenizando em direção às áreas mais afastadas das cidades, onde a modificação do solo acaba sendo menor por diversos motivos, entre eles a especulação imobiliária.

Desta forma, observa-se também, um grande potencial de influência dos materiais usados na construção civil, vidros, entre outros fatores, automóveis, acarretando na intensificação cada vez maior do calor e alterando a sensação térmica nesses locais mais urbanizados, se configurando uma verdadeira ilha de calor, ainda podendo ter influencia sobre a direção e velocidade dos ventos e podendo mudar até o regime pluviométrico destes locais. Dentro da perspectiva no estudo do clima urbano, Monteiro (1976) mostra de maneira mais agregada, a partir dos subsistemas: Termodinâmico, Físico-Químico e Hidrometeórico, que discorrem, de acordo com os canais de percepção humana do conforto térmico, da qualidade do ar e do impacto meteórico, respectivamente. 
O Subsistema Termodinâmico traz alguns fenômenos importantes para o estudo do clima urbano, entre eles o estudo do conforto ou desconforto térmico que constitui-se de um gama de mecanismos onde dentro de um determinado espaço ou ambiente marcado por características térmicas, sendo essa, influência da temperatura do ar, umidade relativa e velocidade dos ventos, uma quantidade $\mathrm{x}$ de pessoas sintam-se agradáveis "sensação de bem-estar" ou desagradáveis "sensação de desconforto" devido ao calor ou frio.

[...] O conforto térmico exprime satisfação com o ambiente térmico, sendo vários fatores que influenciam, entre eles os aspectos físicos relacionados aos processos de trocas de calor: condução, convecção, radiação e evaporação que ocasionam no organismo ganhos e perdas de energia com o meio, através da influência das variáveis meteorológicas como a temperatura, umidade, movimento do ar e radiação responsáveis por uma maior ou menor sensação de conforto térmico. Deve-se considerar também, as variáveis fisiológicas e psicológicas que variam de indivíduo para indivíduo conforme a percepção e preferências térmicas (PAGNOSSIN, BURIOL; GRACIOLLI, 2001, p. 151).

Desta forma, é visto que estudos de conforto térmico abordam análises que consideram o próprio corpo humano e seus mecanismos termorreguladores, levando-se em consideração os objetivos de pesquisas sobre esta temática apontando o ser humano e o ambiente como próprios objetos de estudo. Nota-se assim, o balanço de alteração ambiental antrópica como agente de total influência nas condições de conforto térmico local, apontando-se as condições de modificação às variáveis ambientais impostas por ações de transformação da terra e construção civil.

\section{A INTERAÇÃO HOMEM X MEIO AMBIENTE E O USO INADEQUADO DO SOLO}

A ação do homem tem de ser acrescentada à lista de fatores que determinam o caráter do solo, visto que ela assume, pelo menos ao nível local, maior significado que todos os demais fatores naturais em conjunto (DREW, 2005).

A degradação dos recursos naturais é uma realidade constante. Naturalmente essas áreas estariam em condições de equilíbrio, mas a intervenção do homem causa alterações, que resultam em processos não usuais no sistema, ou seja, os impactos ambientais. 0 desgaste do solo pode ocorrer de várias maneiras diferentes, geralmente resultantes de seu mau uso e conservação por parte das atividades humanas. Como consequência disso ocorre erosões, enchentes, sedimentação, salinização, dentre outros. A desertificação ambiental, ela ocorre em um determinado solo quando transformado praticamente em deserto, que pode ocorrer de uma forma natural ou através da ação humana. Sua vegetação vai se reduzindo até extinguir-se, dependendo de como vai ser desgastado esse ambiente, seu solo perderá propriedades, deixando-o infértil. Essa desertificação ocorrerá de várias maneiras como, por exemplo: através da prática de pecuária, desmatamentos, práticas inadequadas de irrigação, queimadas, principalmente por meios de urbanização levando a toda a restruturação impermeável de sua cobertura.

O manejo inadequado do solo pelo uso de maquinarias pesadas tem causando a sua compactação, dificultando a penetração das raízes das plantas e a infiltração das águas das chuvas, que escoam carregadas de partículas para os corpos d'água, causando danos erosivos e assoreamento, interferindo na qualidade dos cursos fluviais (ROSS, 1994).

O desmatamento de novas áreas para dar lugar a formações tanto de casas, quanto de prédios, ruas e estradas, é o que gera uma redução da cobertura vegetal, tornando o solo exposto, adulterando inteiramente o ambiente que antes era natural. A vegetação desempenha uma significativa função de fixação do solo, amenizando os riscos de deslizamentos e mesmo da erosão. As instabilidades ecológicas afetam tanto o ser humano hoje, quanto as pessoas da geração futura, na qual se encaminha para enfrentar sérios problemas ao longo dos tempos. A ação antrópica sabe-se que é a principal causa do desequilíbrio do movimento ecológico atualmente e muitas das diversas atividades que o ser humano pratica, causam mudanças intensas e rápidas, que os recursos naturais não conseguem anular a tempo os efeitos negativos.

A forma premeditada em que o homem tem em adquirir maior e mais conforto a cada dia torna-o mais individualista com o meio ambiente, pois desfruta de todas as riquezas naturais em proveito pessoal. A restauração do ambiente em locais no qual são bastante urbanizados é quase improvável. 
Os despojos gerados através do homem sujam o meio ambiente gerando condições indesejáveis até duradouras.

\section{MATERIAIS E MÉTODOS}

“O clima pode ser definido como função característica e permanente do tempo, num lugar, em meio a suas infinitas variações[...]” (MASCARÓ, 1991 apud ALMEIDA, 2005, p. 11). Desta forma, interpretamos clima, como sendo a junção de variantes e dados atmosféricos em um determinado local durante um determinado período cronológico; nota-se a importância dos estudos sobre este, justamente por tratar-se de um campo científico que esta diretamente ligada a toda a vida no planeta, e a partir deste destoam-se inúmeros conhecimentos complementares para diferentes áreas. Desta forma, se pondo em função de uma pesquisa sobre conforto térmico em uma cidade exposta as condições de um clima de semiárido no nordeste brasileiro; justificando-se tal local como objeto de estudo, por entendê-lo como área susceptível a formação de clima urbano com presença de ilhas de calor, justamente devido a influência e suas características atmosféricas, expostos a altas temperaturas, baixos índices de precipitação e consequentemente também baixos índices de umidade relativa do ar.

A cidade de Caicó/RN, localizada em latitude (-6.45981) próxima ao Equador imaginário e o Equador Térmico, apresenta como evidentes características climáticas, temperaturas elevadas; umidade reduzida, pouca precipitação; baixa nebulosidade; (AYOADE, 1991). Nota-se em sua formação, características estruturais de uma cidade de certa forma em desenvolvimento, porém sobre um arranjo avulso e sem controle de gestão, totalizando uma mancha urbana que expõe a face da desorganização espacial.

Desta forma, o presente trabalho se deu mediante uma análise higrotérmica de dois pontos distintos no município de Caicó - RN (Figura 01), buscando a apresentação das condições de conforto térmico numa perspectiva urbana e rural.

FIGURA 01: Mapa de Localização do município de Caicó, estado do Rio Grande do Norte.

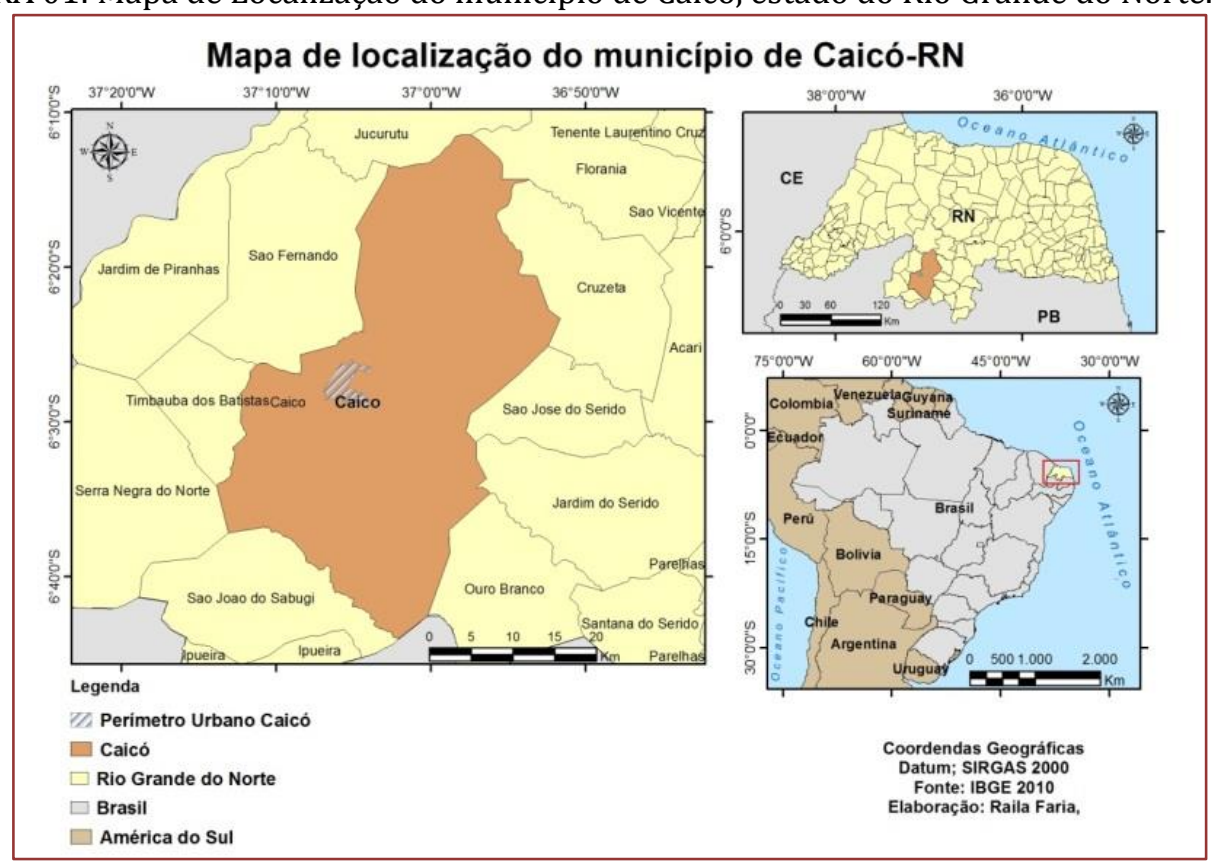

0 ponto 1 (Figura 02), rua aberta intensamente urbanizada na zona central da cidade, exposta a alta insolação, caracterizada por uma via asfaltada de constante movimentação; 
FIGURA 02: Avenida central e urbanizada da cidade.

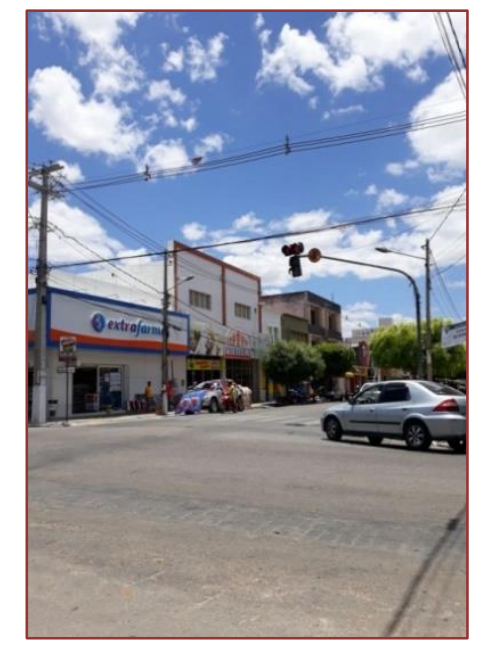

Fonte: Acervo dos autores, 2018.

e o ponto 2 (Figura 03) localizado na zona rural do município, caracterizada por pouca modificação ambiental, com solo exposto e intensa cobertura vegetal tanto gramínea como arbórea, próxima a um corpo hídrico de tipo açude e relativamente preservada.

FIGURA 03: Área de ambiente rural do município em estudo.

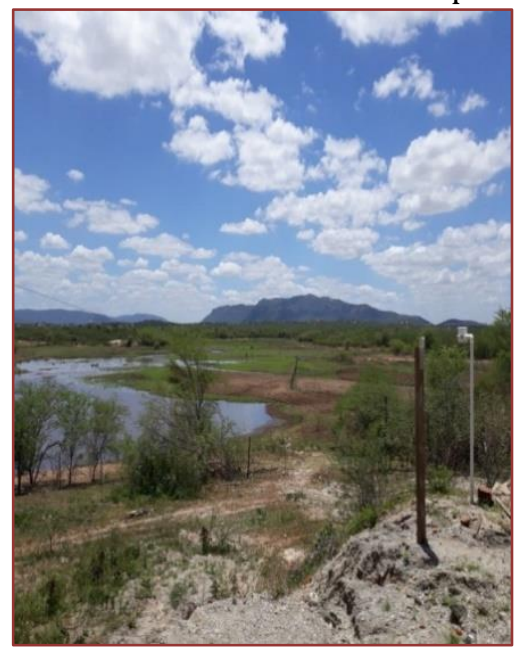

Fonte: Acervo dos autores, 2018.

A realização de tal estudo se dá, mediante a percepção de que as condições climáticas de uma área urbana e de construção densa são totalmente distintas de espaços do meio natural, espaços não urbanizados ou tão alterados pelo homem, podendo haver diferenças de temperatura, velocidade do vento, umidade, pureza do ar entre outras. É visto que a atuação do homem no meio influi de maneira drástica na interação entre estrutura urbana e atmosfera, a essa modificação antrópica estão ligadas ações que envolvem toda ação de construção e organização civil, distribuição das áreas verdes, todos esses, fatores da urbanização que influem de maneira direta na determinação de climas locais, estes denominados de climas urbanos (LOMBARDO, 77-78 p., 1985.).

Portanto, tal pesquisa efetivou-se em um período de 10 meses de coleta de dados de temperatura (ํㅡ) e Umidade Relativa (\%) do ar, de maio de 2016 a fevereiro de 2017, através da instalação de aparelhos termohigrômetro automático da marca Akso AK 170, que fez o registro de dados horários das variáveis aqui citadas, somando um total de 6.888 dados para cada um dos pontos. Os termohigrômetros tiveram como suporte abrigos meteorológicos fixados à uma altura média de 1,70 metros, feitos com tubo de PVC e um ralo do mesmo material, ambos de cor branca, o que favoreceu uma maior refletância solar evitando a interferência de agentes externos.

Por fim, realizou-se em laboratório um processo de mineração dos dados, onde por meio do auxílio do software Libreoffice Calc, se possibilitou o processamento de dados em forma de médias, amplitude, valores máximos e mínimos absolutos e valores maiores que $40^{\circ} \mathrm{C}$. Por fim, mediante os 
resultados obtidos, busca-se a consolidação junto a analises bibliográfica que possam ser levadas à discussão junto a gestão pública e população da área em estudo, para que se possibilite uma boa interação e resultados práticos positivos da pesquisa.

\section{RESULTADOS E DISCUSSÕES.}

Por meio deste trabalho, apresenta-se em uma análise de perspectivas urbana e rural, as singularidades ambientais que influenciam diretamente nas condições climáticas locais atuantes no município de Caicó. É visto que, as substituições de componentes naturais por formas urbanas podem estabelecer resultados invasivos a condições também de conforto humano, como o próprio processo de formação de ilhas de calor, por meio da modificação no balanço energético das cidades.

No processo de capeamento e qualquer processo de cobertura artificial do solo requer muito cuidado, no meio urbano torna-se muito frequente a ocorrência e aplicação de camadas distintas e artificiais de diferentes materiais e texturas. Tais materiais são impostos sobre a camada superficial do solo, sobrepondo assim sua porosidade, desta forma impermeabilizando e anulando sua capacidade natural de drenagem.

Mediante Pedron (et al, 2004), essas camadas artificiais apresentam uma transição irregular de materiais sobre uma heterogeneidade morfológica do solo, interferindo assim, de forma direta no regime hídrico e térmico destes. Nas condições hídricas, por meio da impermeabilidade já citada, ocasionando um processo de maior escorrimento de água sobre os centros urbanos em períodos de precipitação; já em condições térmicas, dar-se por meio da constituição e aplicabilidade dos materiais utilizados, como por exemplo, o pavimento asfáltico (piche), os quais tendem a ser de cor preta ou cinza, tendendo a manter sua temperatura em $65^{\circ} \mathrm{C}$ ou mais, com valores de refletância solar entre 5 a $10 \%$ quando novos; desta forma, contribuindo para autos valores de temperatura e desconforto nesses centros urbanos.

No caso da cidade de Caicó-RN, localizada na região semiárida do Brasil, esta exposta a altas temperaturas provenientes da grande quantidade incidente de energia solar durante todo o ano, e períodos chuvosos concentrados em poucos meses, desta forma estas condições de uso da terra urbana não condizentes as características ambientais locais, condicionam a condições críticas de conforto humano na cidade.

Durante a pesquisa, em termos de coleta, analise e mineração dos dados propostos, obteve-se resultados de valores numéricos referentes a médias, valores máximos, valores mínimos, valores maiores que $40^{\circ} \mathrm{C}$ e suas amplitudes, todos referentes a variável atmosférica de temperatura do ar; por meio desta análise, buscou-se a caracterização da relação e diferenciação entre os dois pontos e suas singularidades características (Figura 04).

FIGURA 04: Tabela dos valores referentes a Temperatura do ar.

\begin{tabular}{|l|c|c|}
\multicolumn{1}{|c}{ Temp.Pontos } & Ponto 1: Zona Urbana & Ponto 2: Zona Rural. \\
\hline Temperaturas Médias $\left({ }^{\circ} \mathrm{C}\right)$ & 30,9 & 29,4 \\
\hline Temperatura Máxima absoluta $\left({ }^{\circ} \mathrm{C}\right)$ & $43,5(29 / 10-14: 22)$ & $41,1(26 / 01-14: 51)$ \\
\hline Temperatura Mínima absoluta $\left({ }^{\circ} \mathrm{C}\right)$ & $20,9(23 / 07-08: 10)$ & $19(02 / 07-04: 26)$ \\
\hline Valores maiores que $40^{\circ} \mathrm{C}$ & 133 & 4 \\
\hline
\end{tabular}

Fonte: Acervo dos autores, 2018.

Partindo de uma função comparativa, notou-se no âmbito das médias uma diferença de 1,5ํㅡ entre os pontos: o Ponto 1 com média de 30,9º e o Ponto 2 com média de 29,4ํㅡ. Levando-se em comparação dados de valores máximos absolutos, o ponto 1 apresentou o valor de 43,5C e o ponto 2 apresentou valor de $41,1^{\circ} \mathrm{C}$, destacando uma diferença para suas máximas de $2,4^{\circ} \mathrm{C}$. Também comparando as temperaturas mínimas absolutas, o ponto 1 apresentou valor de temperatura de $20,9^{\circ} \mathrm{C}$ e o ponto $2,19,9^{\circ} \mathrm{C}$, destacando assim uma diferença de exatamente $1^{\circ} \mathrm{C}$ entre eles. Para esta análise, comparou-se também valores maiores que $40^{\circ} \mathrm{C}$ entre os pontos 1 e 2 , totalizando uma diferença de 129 valores, com resultados 33x maiores entre os pontos, sendo o ponto 1 , o detentor dos maiores valores, enquadrando-se assim, como um ponto de condições atmosféricas mais depressivas e consequentes referente ao conforto humano. 


\section{CONSIDERAÇÕES FINAIS}

De acordo com os dados aqui apresentados, observa-se como a ocupação e uso inadequado da terra, podem acarretar em alterações do microclima local, portanto, por meio de uma análise dos pontos 1 e 2 em espaços tão próximos dentro do município de Caicó, constata-se a presença do advento de ilha de calor. Assim, por meio desta pesquisa, concordando com a afirmação de SANTOS (et al., 2012) em seus estudos para cidades do semiárido paraibano, quando este afirma que "As mudanças na paisagem, através das diversas formas de uso e ocupação do solo, tem gerado transformações significativas na dinâmica climática de áreas urbanas".

Notando-se que a interação homem e meio ambiente pode ser detectada por meio da medição e análise de diversos indicadores, é visto que a modificação e substituição de aspectos físicos da paisagem podem acarretar em diversas resoluções e facetas, sejam estes, impactos positivos ou negativos, portanto, percebe-se que a substituição de componentes naturais por formas urbanas podem estabelecer resultados hostis, como o exposto com relação aos valores de temperatura superiores aos $40^{\circ} \mathrm{C}$, para o município de Caicó, no estado do Rio Grande do Norte, e à condições também de conforto humano, como o próprio processo de ilhas de calor, por meio da modificação no balanço energético das cidades. Apontamos assim, como medida de direta resolução, a conservação dos aspectos naturais dentro de grandes e pequenos centros urbanos, o arrefecimento natural arbóreo surge ainda como principal medida a custo e beneficio para a resolução de problemas como ilhas de calor.

\section{BIBLIOGRAFIA}

[1] Almeida Junior, Nicácio Lemes de. Estudo de Clima Urbano: uma proposta metodológica. 2005. $92 \mathrm{f}$. 10 - 17 p. Dissertação (Mestrado em Física e Meio Ambente) - Universidade Federal do Mato Grosso, Instituto de Ciências Exatas da Terra, Cuiabá, 2005.

[2] Ayoade, J. O. Introdução à Climatologia para os Trópicos. Editora Bertrand Brasil, 3ạ Edição, 1991.

[3] Azevedo, Antônio Carlos de; Dalmolim, Ricardo Simão Diniz; Kaminski, João. Pedron, Fabricio de Araújo. Solos Urbanos. Ciência Rural. Santa Maria. v.34, n.5, p.1647-1653, set - out, 2004.

[4] Drew, David. Impacto do homem sobre os aspectos do ambiente. Processos interativos homem-meio ambiente; tradução: Santos, João Alves dos. 6ª ed. Rio de Janeiro, Bertrand Brasil, 2005, 43 - 56 p.

[5] Faria, Carlos Eugênio de. Os eventos geográficos e a expansão urbana de Caicó: desigualdades e coexistências na urbe. Natal, IFRN Editora,2011. 41 - 80 p.

[6] Kayano, Mary Toshio; Andreoli, Rita Valéria. Clima da Região Nordeste do Brasil. In: Cavalcanti, Iracema Fonseca de Albuquerque [et al] (org.). Tempo e Clima no Brasil. São Paulo: Oficina de Textos, 2009. 213-218 p.

[7] Lamberts, Roberto; Xavier, Antônio Augusto de Paula. Conforto e Stress térmico. Atualizado por: Goulart, Solange. Florianópolis: LabEEE, 2008. 04 - 08, 69 - 104 p.

[8] Lombardo, Magda Adelaide. Urbanização e ilha de calor. In O exemplo de São Paulo. São Paulo: Hucitec, 1985. 77-110 p.

(Org.). Ilha de calor nas metrópoles:

[9] Monteiro, C. A. F. Teoria e Clima Urbano. Série Teses e Monografias, no25. São Paulo: Instituto de Geografia/USP, 1976.181p.

[10] Pagnossin, E. M.; Buriol, G. A.; Graciolli, M. A. Influência dos elementos meteorológicos no conforto térmico humano: bases biofísicas. Disciplinarum Scientia. Série: Ciên. Biol. e da Saúde, Santa Maria, v. 2, n. 1, p. 149-161, 2001. Disponível em: <http://sites.unifra.br/Portals/36/Csaude/2001/influencia.pdf>. Acesso em: 9 mai. 2018.

[11] Ross, J. L. S. Análise Empírica da fragilidade dos Ambientes Naturais e Antropizados. Revista do DGUSP, n. 8, 1994.

[12] Santos, Joel Silva dos; Silva, Vicente de Paulo Rodrigues da; Silva, Eduardo Rodrigues da; Araújo, Lincoln Eloi de; Costa, Angelina Dias Leão. Campo Térmico Urbano e a sua Relação com o Uso e Cobertura do Solo em Cidade Tropical Úmida. Revista Brasileira de Geografia Física, [s.l], v.3, p. 540 - 557. 2012.

[13] Silva, Charlei Aparecida da; Fialha, Edson Soares; Steinke, Ercília Torres. Experimentos em Climatologia Geográfica. São Paulo: UFGD, 2014. 392 p. 


\section{Capítulo 15}

*Dinâmica de uso e a pseudo recuperação hidroambiental da sub-bacia hidrográfica do Rio Caatinga do Moura no Sertão da Bahia

\section{Janiel Lopes de Oliveira}

Resumo: Trabalho desenvolvido com objetivo de analisar a dinâmica atual de uso e ocupação do solo na Sub-bacia Hidrográfica do Rio Caatinga do Moura (SHRCM), teve como discussão a recuperação hidroambiental que segundo órgãos gestores e executivos foi realizada em área de abrangência da Sub-bacia. Para alcançar o objetivo do estudo foi realizado mapeamento da área com uso de recursos do sistema de informação geográfica e o geoprocessamento, foram analisados dados e informações sobre as atividades desenvolvidas na sub-bacia. Os resultados obtidos indicam que 49,8\% da bacia apresenta remanescente de vegetação, 25,3\% solo exposto, 13,2\% pastagem, $10,6 \%$ agave, 0,7\% culturas anuais (vale), 0,2\% influencia urbana. A sub-bacia apresenta gradiente topográfico de $500 \mathrm{~m}$, tem predominância de relevo plano e suave ondulado. Foi identificado que as obras de intervenção realizadas para recuperação hidroambiental não levou em consideração os aspectos naturais de formação da vertente nem os resultados obtidos a partir dos diagnósticos apresentados.

Palavras-chave: Sub-bacia Hidrográfica. Recuperação Hidroambiental. Geoprocessamento. 


\section{INTRODUÇÃO}

A apropriação de recursos naturais (solos, minerais, vegetação e água) é uma prática constante em que o ser humano busca suprir anseios e necessidades. 0 solo é um dos recursos naturais explorado de forma intensa na atualidade, indispensável para o desenvolvimento de atividades como a agricultura. A partir de Lepsch (2002) entende-se que o processo de uso e ocupação do solo no decorrer do tempo histórico faz parte de um conjunto de ações antrópicas na busca por suprir necessidades básicas à sobrevivência.

Como toda exploração deixa marcas no ambiente transformando a paisagem, com o solo não é diferente. Surgi problemas ambientais relacionados a perda de propriedades, fertilidade, salinização, erosão e contaminação. Para Cunha e Guerra (2010) dentre as atividades que causam degradação no ambiente sendo o solo um dos elementos afetados cita-se: práticas agrícolas, desmatamento, mineração, superpastoreio e a urbanização.

Em busca por solucionar os problemas relacionados ao uso e exploração do solo e questões de degradação ambiental, a bacia hidrográfica é adotada como unidade básica naturalmente definida. Espaço geográfico que contribui para a gestão de recursos naturais e o desenvolvimento de projetos visando minimizar, recuperar ou conservar o meio ambiente. Segundo Botelho e Silva (2004) a bacia hidrográfica possibilita o reconhecimento de diversos componentes, processos e interações, é possível avaliar de forma integrada ações humanas sobre o ambiente e seus desdobramentos hidrológicos.

De acordo com Pires et al., (2002) a bacia hidrográfica pode ser entendida como unidade direcionada à conservação dos recursos naturais, agregada ao conceito de Desenvolvimento Sustentável. Área geográfica em que pode ser implantada políticas de conservação dos recursos naturais com abrangência que envolve além dos aspectos hidrológicos, toda estrutura biofísica.

Este trabalho teve como objetivo analisar a dinâmica atual de uso e ocupação do solo na Sub-bacia Hidrográfica do Rio Caatinga do Moura (SHRCM), foi discutida a recuperação hidroambiental que segundo órgãos gestores e executivos foi realizada em área de abrangência da Sub-bacia devido a degradação ambiental e escassez hídrica que envolve o território.

As questões hídricas podem ser compreendidas a partir de situações reais de disponibilidade e aumento de demanda dentro do contexto social, econômico e ambiental. Existe uma relação entre estresse e escassez de água, influenciados por mudanças globais com eventos hidrológicos extremos, como exemplo cita-se: chuvas intensas e períodos de secas prolongados (TUNDISI, 2008).

Para análise das questões ambientais que envolve a SHRCM e alcance do objetivo supracitado, foi realizado a identificação das principais atividades desenvolvidas na área de estudo e a cobertura predominante no território. Foram analisados dados e informações sobre as atividades e práticas que se denominou recuperação hidroambiental, considerou-se os aspectos naturais do ambiente em seu estágio atual e as intervenções antrópicas.

Para conhecimento sobre a dinâmica atual de uso e ocupação do solo na SHRCM, foi realizado o mapeamento da área de estudo com subsidio de recursos do sistema de informação geográfica (SIG) e o geoprocessamento. Segundo Dias et al., (2004) o uso de recursos tecnológicos e o geoprocessamento permitem realizar investigações oferecendo produtos digitais básicos e aplicados para análise de cada situação ambiental definida.

\section{MATERIAIS E MÉTODOS}

\section{1 ÁREA DE ESTUDO}

A SHRCM está localizada no município de Jacobina-Ba, sentido oeste noroeste do território municipal (figura 1), tem como principal afluente o Rio Caatinga do Moura. Se constitui a partir da contribuição de canais efêmeros e intermitentes que fluem das partes elevadas da vertente. A subbacia é uma contribuinte da bacia hidrográfica do Rio Preto, afluente do Salitre na região fisiográfica do Submédio São Francisco (VIEIRA et al., 2005).

De acordo com o mapa de cobertura vegetal IBGE, (2004) a região apresenta vegetação com dominância de Savana Estépica, Savana Estépica Arbustiva e vegetação secundaria, existi parcelas de terras direcionadas para atividades agropastoris. 
O Rio Caatinga do Moura é margeado em parte por terras baixas que compõem o vale de Caatinga do Moura. É comum o desenvolvimento de práticas agrícolas para subsistência familiar e o consumo regional. Áreas baixas que constitui o vale são direcionadas para o cultivo e produção de banana nos dias atuais, coexistindo com enclaves de culturas anuais (bata doce, feijão, milho, mandioca (aipim) e hortaliças).

A parte alta da vertente apresenta uso e ocupação direcionada a práticas diversas com baixo nível produtivo e tecnológico. É comum áreas de pastagens direcionadas à pecuária extensiva ou a caprinocultura, cultivares de agave (sisal) e plantio de mamona (IBGE, 2004).

Figura 1: mapa de localização da Sub-bacia hidrográfica do Rio Caatinga do Moura.

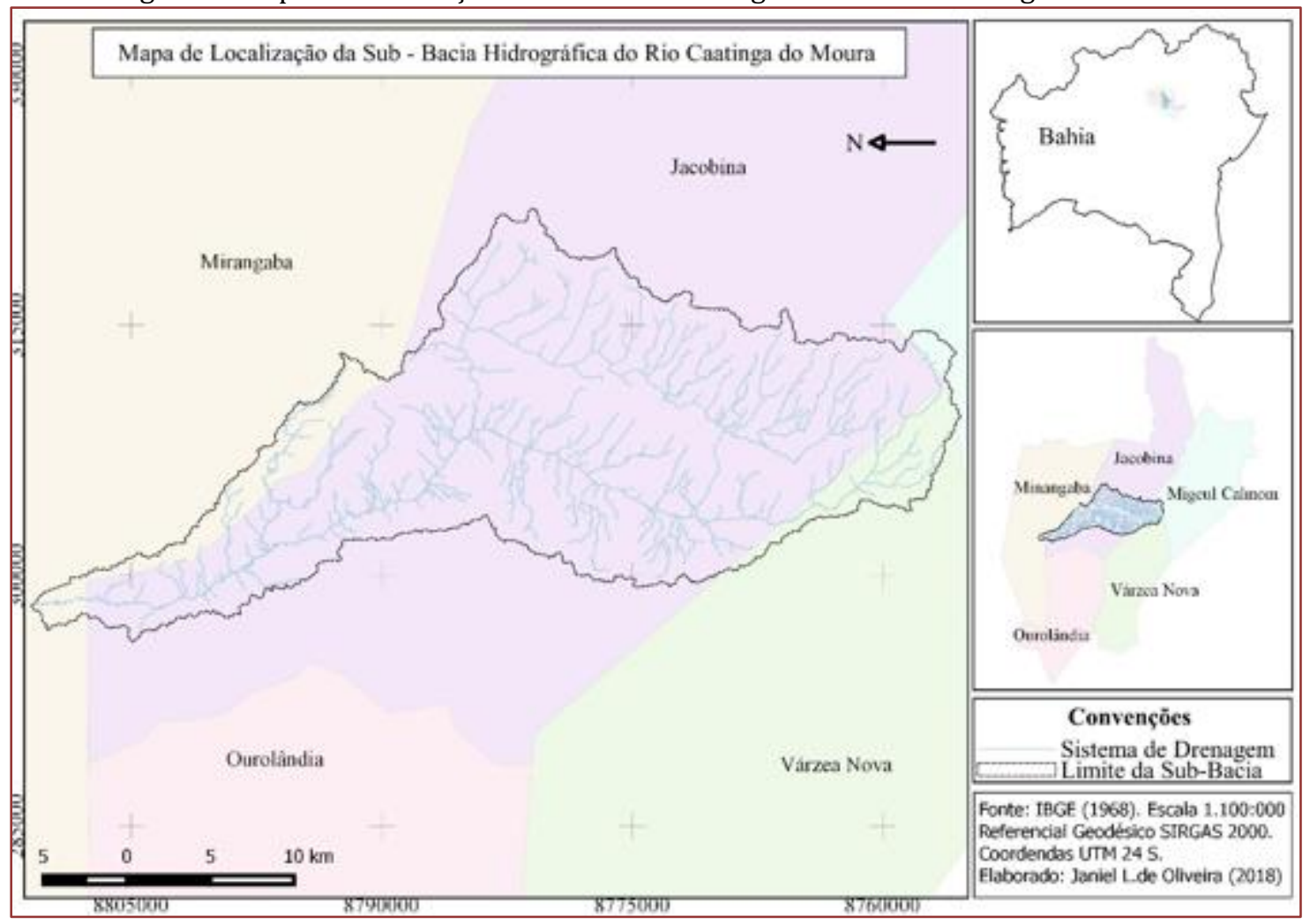

Fonte: Autor, (2018).

As características naturais da vertente pode ser um dos fatores que possibilitaram a formação de comunidades na extensão do Rio Caatinga do Moura. Existi aglomerados populacionais em pontos específicos desde o alto curso (comunidade de Olhos D’água de Caatinga do Moura) até o baixo curso (sede do Distrito de Caatinga do Moura).

\subsection{RECURSOS E PROCESSAMENTO DAS INFORMAÇÕES}

Para o desenvolvimento da pesquisa e obtenção de dados foram utilizados periódicos, relatórios e artigos sobre a área de influência da SHRCM, recursos do geoprocessamento para delimitação e mapeamento da área de estudo.

No processamento dos dados foi utilizado o Software Quantum Gis 2.8 (Qgis), arquivos disponibilizados pelo IBGE (2004), malha digital dos municípios do Brasil (arquivo vetorial), carta topográfica do município de Mirangaba - Ba, folha SC-24-N-III, escala 1:100.00. Mapa índice Topodata (MDE), INPE (2011), folhas 11-S-42, 10-S-42, imagem espacial com cobertura da SHRCM disponível no Google Earth - Pro.

A delimitação da bacia hidrográfica foi realizada a partir do complemento Gras/ no Qgis, teve como recurso primário o MDE (modelo digital de elevação). Foi realizado a conversão do arquivo para o 
sistema de coordenadas UTM 24 S, seguindo de recorte para delimitação, comando Grass/gis Mapset - Novo mapst - bacia. 0 mesmo material formou a base para o desenvolvimento dos mapas de hipsometria e declividade.

O mapa de uso e ocupação com cobertura predominante foi obtido a partir da utilização das imagens espaciais com resolução 4.800 x 2.843. As mesmas foram salvas em formato JPEG, por não possuírem um sistema de referência foram georreferenciadas e salvas em formato raster, seguido da composição de cena única e reprojeção para o Datum SIRGAS 2000, sistema de coordenadas UTM - Zona 24 Sul.

Após o georreferenciamento das imagens e a composição da cena única foi realizado a vetorização manual utilizando a ferramenta alternar edição - adicionar feição do Qgis com o uso do método de interpretação visual em tela (NOVO \& PONZONI, 2001).

Foi realizado visita a campo no período corrente de 03/01/2018/ a 20/01/2018, foi observado a situação atual de uso e ocupação do solo em parte do vale de Catinga do Moura, bem como situações de desgaste ambiental no território.

\section{RESULTADOS E DISCUSSÃO}

A SHRCM apresenta dinâmica atual de uso e ocupação do território direcionada para atividades agropastoris, é comum o desenvolvimento de práticas agrícolas voltadas para subsistência familiar e o consumo regional. De acordo com o mapa de uso e ocupação do solo (figura 2), 49,8\% do território é recoberto por remanescentes de vegetação. São áreas com vegetação rala em que se pratica o pastoreio extensivo. De acordo com o IBGE, (2004) esse tipo de cobertura pode ser classificado como Vegetação secundária.

O solo exposto foi identificado em $25,3 \%$ da sub-bacia (quadro 1), representa faixas territoriais com a ausência de cobertura vegetal nativa. Apresentam vestígios de degradação ambiental com incisões erosivas e acúmulo de sedimentos em partes baixas da vertente. De acordo com Accioly et al., (2017) essa classe de cobertura traz particularidades em regiões semiáridas, tem condições específicas de vegetação ou pastagens com baixo nível de cobertura e elevado estágio de degradação.

As áreas de pastagens se constituem em 13,2\% da SHRCM, são formadas por gramíneas direcionadas para o pastoreio extensivo. Essas áreas são recobertas em parte pelo capim buffel (Cenchrus ciliares), espécie comum na região que apresenta boa resistência a períodos de estiagem e brotam nos períodos de chuvas, desde que não haja o superpastoreio em períodos de secas intensa.

Os cultivares de sisal ou agave (Agave sisalana) recobrem 10,6\% da sub-bacia, cultura comum em parte dos sertões baiano, responsável pela ocupação de mão de obra informal e pela sustentação de famílias sertanejas, é uma das principais fontes de renta em comunidades do interior (SOUSA, 2015).

As culturas anuais correspondem a aproximadamente $0,7 \%$ da SHRCM, se concentram na baixa vertente que forma o vale de Caatinga do Moura. Local direcionado a práticas agrícolas com o uso de irrigação por encharcamento. É comum cultivares de banana e enclaves de culturas diversas que formam a base de sustentação familiar (milho, feijão, bata, mandioca, hortaliças), parte da produção é escoada para feiras regionais.

As áreas de influência urbana representam $0,2 \%$ do território, composto por aglomerados populacionais que forma comunidades influenciadas pela existência do vale de Caatinga do Moura. 
Figura 2: Uso e ocupação do solo da sub-bacia hidrográfica do Rio Caatinga do Moura.

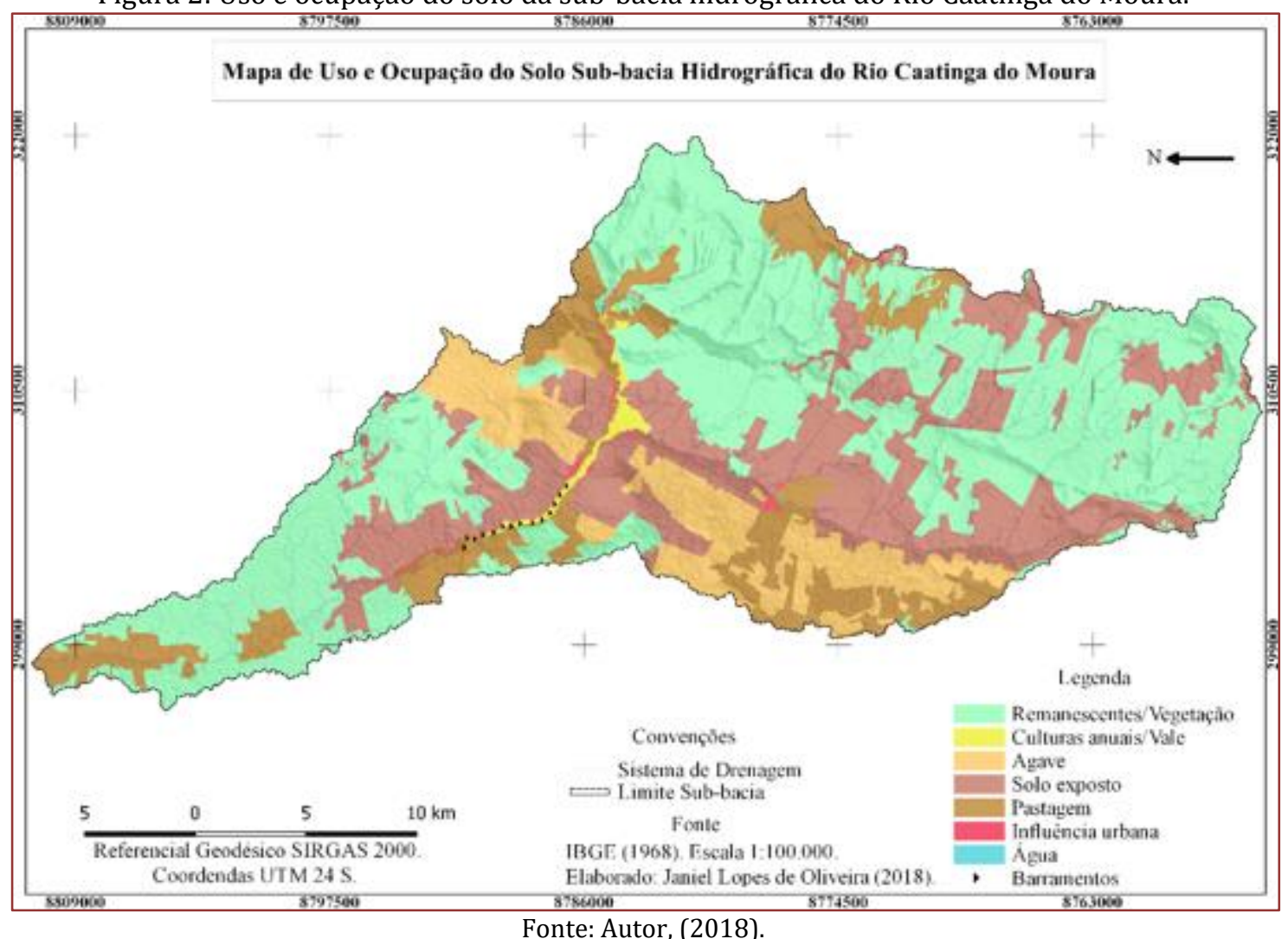

Os barramentos identificados no mapa representam os locais em que faram construídas as estruturas de contenção para armazenamento subsuperficial de águas pluviais em períodos de precipitação (chuvas). São 13 barramentos em espaçamento aproximado de 500 metros, inseridos na classe identificada como Culturas anuais/Vale.

Quadro 1: percentual de uso e ocupação do solo SHRCM.

\begin{tabular}{|l|c|c|}
\multicolumn{1}{c|}{ Classe predominante } & Área ocupada & Percentual \\
\hline Culturas anuais/Vale & $4.4 \mathrm{~km}^{2}$ & $0,7 \%$ \\
\hline Remanescentes/Vegetação & $315 \mathrm{~km}^{2}$ & $49,8 \%$ \\
\hline Solo exposto & $160 \mathrm{~km}^{2}$ & $25,3 \%$ \\
\hline Pastagem & $84 \mathrm{~km}^{2}$ & $13,2 \%$ \\
\hline Agave & $67 \mathrm{~km}^{2}$ & $10,6 \%$ \\
\hline Influência urbana & $1.6 \mathrm{~km}^{2}$ & $0,2 \%$ \\
\hline Água & $0.08 \mathrm{~km}^{2}$ & $0,01 \%$ \\
\hline
\end{tabular}

Fonte: Autor 2018.

A partir da análise de campo foi identificado que parte da média vertente passa por processo de transformação nas atividades produtivas, é comum a perfuração de poços artesianos para a irrigação de terras secas. As áreas objetivam ou são ocupadas por culturas diversas (melancia, abóbora, banana, tomate e pepino). Fator pontual pode contribuir para a aceleração de problemas ambientais. Promove a extinção de exemplares da flora ainda existente. Pode contribuir com a intensificação de problemas ambientais e a disponibilidade de água para as comunidades que integram a sub-bacia.

O curso d'água perene que corta o Distrito de Catinga do Moura apresenta vestígios de escassez, está morrendo aos poucos, parte do fio d'água que antes corria constantemente tornou-se intermitente. Processo que pode ser potencializado pelo uso desordenado dos recursos naturais existentes na região, extinção cobertura vegetal nativa em conjunto com a má gestão dos recursos hídricos em nível local e regional. 
A ansiedade dos pequenos produtores não é acompanhada por políticas públicas de regulamentação, nem tão pouco de apoio técnico informacional. Em abordagem referente a influência das atividades antrópicas na qualidade das águas da bacia hidrográfica do Rio Salitre, Brito et al., (2005) destaca:

A bacia hidrográfica do Rio Salitre, estado da Bahia, as sub-regiões de Caatinga do Moura (Jacobina), Taquarandi (Mirangaba) e Juazeiro, têm como [...] atividade econômica a agricultura irrigada, cultivando [...] hortifrutícolas para atender aos mercados interno e externo; [...] praticase uma diversidade de sistemas de produção, a maioria de baixa eficiência de aplicação da água de irrigação e com inadequado manejo dos solos, uso de fertilizantes e defensivos favorecendo, consequentemente a poluição das águas ( Brito et al., 2005, p. 2).

Diante dos problemas que envolvem o uso e exploração dos recursos naturais na área de abrangência da SHRCM, surgem propostas e projetos direcionados para recuperação ambiental junto às comunidades. Segundo o Anexo I, termo de referência do ato convocatório № 031/2016, contrato de gestão № 14/ANA/2010, foi solicitado pela AVACAM (Associação dos Agricultores do Vale da Caatinga do Moura) demandas preliminares tendo como objetivo a construção de barragens subterrâneas ao longo do "Rio Veredas da Caatinga". O objetivo geral do projeto era promover a recuperação hidroambiental na sub-bacia hidrográfica.

De acordo com o boletim de notícias do Comitê da Bacia Hidrográfica do Rio São Francisco (CBHSF) divulgado em 30/10/2017, o diagnostico realizado para bacia hidrográfica do Rio Caatinga do Moura apresentou situações ambientais em estágio de degradação avançado. Foi observado a poluição do manancial, erosão do solo e a salinização como agravantes para sustentação da subbacia analisada.

Segundo o Anexo I, termo de referência do ato convocatório № 035/2016, contrato de gestão № 14/ANA/2010, a vazão do rio Caatinga do Moura reduz sensivelmente, não existi água superficial suficiente para atender a demanda de uso na parte baixa da sub-bacia, há situações de conflitos entre os produtores rurais local.

Diante das situações descritas envolvendo a degradação ambiental e as formas de uso e exploração do território na SHRCM, foi realizado as obras de intervenção na região do baixo curso. Tendo como perspectiva o armazenamento subsuperficial de águas da chuva para atendimento de demandas dos produtores rurais. A figura 3 apresenta divulgação referente a conclusão das obras.

Figura 3: Placa divulgando a recuperação hidroambiental no Rio Caatinga do Moura.

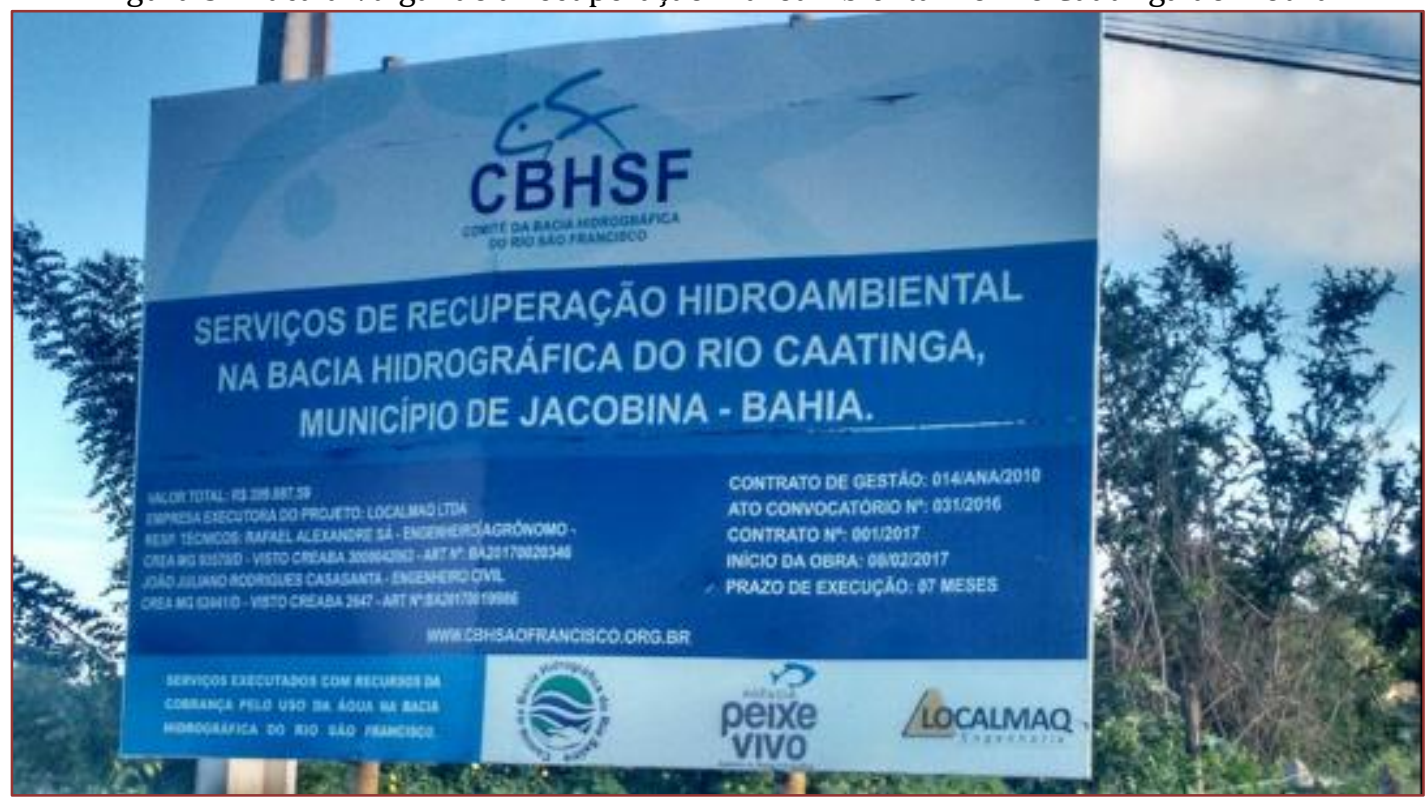


Frente as situações ambientais diagnosticadas questionam-se: as obras realizadas resolvem ou minimizam os problemas ambientais identificados no diagnóstico ambiental apresentado? A intervenção ambiental e os impactos proporcionados pela execução das obras na construção dos barramentos subterrâneos podem ser considerados recuperação hidroambiental para a SHRCM? Houve preocupação de profissionais, técnicos e responsáveis pelas obras quanto a viabilidade técnica e ambiental do projeto? Foi apresentado aos solicitantes e a comunidade alternativas em substituição a construção das barragens subterrâneas considerando o diagnóstico realizado? Houve preocupação quanto aos problemas e impactos futuros que as obras podem representar?

A resposta aos questionamentos mencionados é negativa, considerando o exposto no material disponibilizado à consulta pública pelos responsáveis da obra (ato convocatório № 035/2016, contrato de gestão № 14/ANA/2010; Anexo I, termo de referência ato convocatório № 031/2016, contrato de gestão № 14/ANA/2010;).

Em análise a proposta do projeto, aos resultados apresentados e ao diagnostico ambiental. As abras realizadas atendem a solicitação, mas se contrapõem ao próprio diagnostico, visto que, além da menor disponibilidade de água para irrigação foi identificado situações de erosão e salinização. Nas visitas a campo não foi observado obras de contenção a processos erosivos executadas pelos responsáveis na aplicação do projeto. Não houve intervenção quanto a situação de salinização diagnosticada no vale.

A erosão pode ter influência dos aspectos físicos da sub-bacia, potencializado por ações antrópicas. As características do relevo é um dos parâmetros a ser analisados na busca de entendimento sobre a perda de solo (Crepani et al., 2001). A SHRCM apresenta gradiente topográfico de aproximadamente $500 \mathrm{~m}$, tem altimetria variável entre $542 \mathrm{~m}$ e $1.042 \mathrm{~m}$ (figura 4). Apresenta declividades entre $0 \%$ e $45 \%$ (figura 5), predomina relevo plano e suave ondulado de acordo com a classificação da Embrapa (2018).

A altimetria e a declividade podem influenciar o deslocamento das águas pluviais sentido regiões baixas da vertente. Em seu trajeto realizam o processo de lavagem e lixiviação da superfície, arrasta matérias sólidos e partículas minerais existente em seu caminho, parte do material é armazenado em áreas baixas da bacia ou sub-bacia.

A construção dos barramentos foi realizada em áreas com altitudes entre 542 e 642 metros, tem relevo plano e suave ondulado. Não foram realizadas obras de contenção para as águas pluviais em regiões com cotas topográficas e declividade mais acentuada. Diante do exposto entende- se que, as situações de gênese erosiva e a salinização foram desconsideradas no projeto de recuperação hidroambiental para a SHRCM.

Segundo o diagnostico apresentado no projeto de recuperação para a SHRCM, foi detectado a salinização em áreas de exploração intensa do vale. A construção das barragens subterrâneas pode influenciar o acúmulo do material resultante dos arrastes das águas pluviais. Pode contribuir para intensificar a salinização nas áreas influenciadas pelas barragens. Esse fator não foi considerado tendo em vista que os barramentos foram construídos em locais que apresentam as menores cotas altimétricas (ver mapa 4) e partes baixas da sub-bacia com declividade entre 0\% e 8\% (ver mapa 5).

O papel institucional dos comitês de bacias hidrográficas de acordo com o definido pela lei federal 9.433/97 é: arbitrar e mediar situações conflituosas no que diz respeito ao gerenciamento e conservação dos recursos hídricos. Acompanhar as ações em favor da resolução de problemas relacionados a disponibilidade e qualidade das águas. Essas funções não foram executadas com êxito na região da SHRCM.

As ações realizadas em favor da recuperação ambiental ou hidroambiental em bacias e sub-bacias hidrográficas devem ser realizadas tendo como objetivo, a efetiva preocupação em minimizar impactos e resolver problemas degradativos no ambiente natural antropizado. Não é um instrumento de manobra e promoção partidarista, ferramenta para justificar a cobrança pelo uso da água junto à comunidade, usuários e órgãos federativos de ordem superior. 
Figura 4: mapa hipsométrico Sub-bacia hidrográfica do Rio Caatinga do Moura.

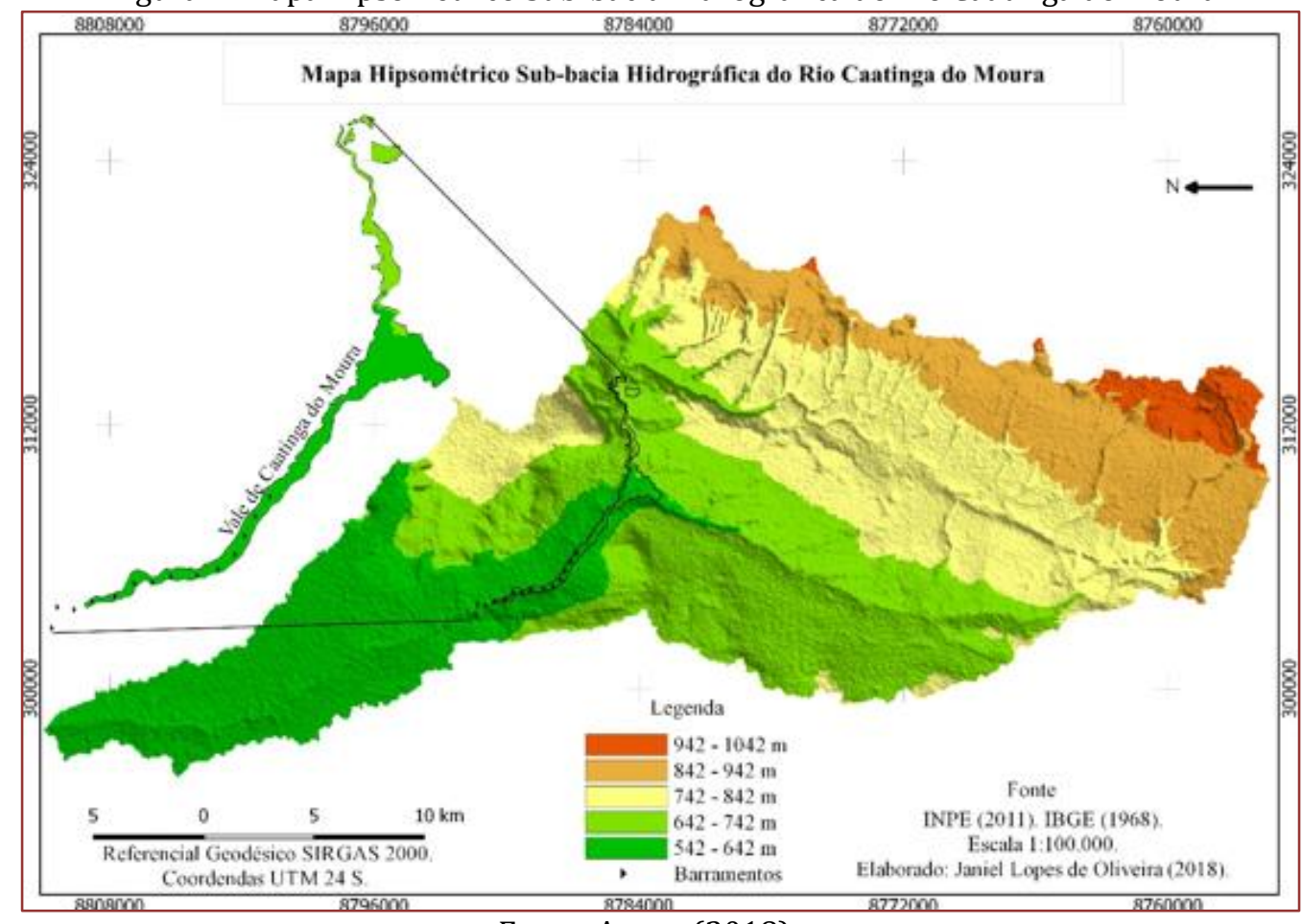

Fonte: Autor, (2018).

Figura 5: mapa de declividade Sub-bacia hidrográfica do Rio Caatinga do Moura.

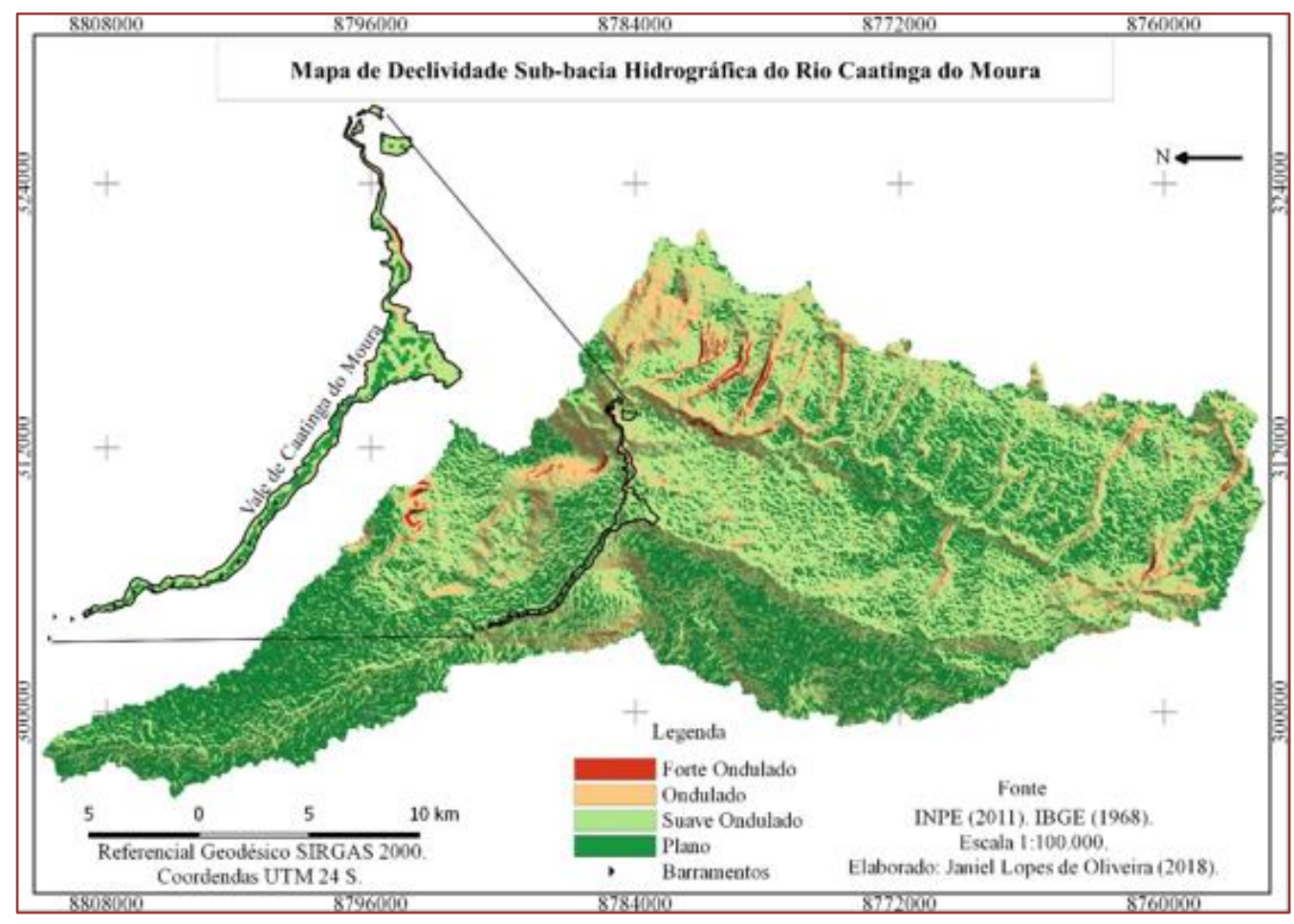

Fonte: Autor, (2018).

O corpo técnico e operacional responsável pelos diagnósticos e obras executadas devem ter em mente não só o faturamento obtido pelas atividades desenvolvidas, mas sim, o compromisso ético de resolver os problemas diagnosticados considerando as peculiaridades ambientais de cada bacia ou sub-bacia hidrográfica em recuperação.

Se não atuarmos respeitando questões socioambientais e a legislação em vigor, dificilmente conseguiremos alcançar a recuperação ambiental ou hidroambiental de uma determinada bacia ou 
sub-bacia hidrográfica. A consequência pode ser a intensificação da escassez hídrica, salinização e erosão de bacias ou sub-bacias como a do Rio Caatinga do Moura, um dos afluentes do Rio Salitre que desagua no Rio São Francisco, área de atuação do CBHSF.

A sociedade, os estudantes e a academia precisam acompanhar, monitorar e contribuir com os processos envolvendo a recuperação hídrica e ambiental, não só de grandes bacias que abastecem centros urbanos de maior relevância, mas em todo território nacional dando atenção a regiões interioranas como as dos Sertões.

\section{CONSIDERAÇÕES FINAIS}

A dinâmica ambiental que envolve a SHRCM precisa ser discutida de forma ampla considerando as práticas predominantes no território e os aspectos físicos naturais que compõem a paisagem local. Esse trabalho faz questionamento sobre as atividades de recuperação implantadas na SHRCM, traz contribuições a serem consideradas em trabalhos futuros ou possível revisão do projeto executado.

A análise apresentada mostra que a recuperação hidroambiental não se concretizou, houve ações e atividades com intervenção ambiental de forma isolada na parte baixa da sub-bacia. 0 projeto pouco contribui para preservar ou recuperar a dinâmica ambiental entre elementos do meio natural: água, solo e vegetação, indicadores básicos que constitui a dinâmica hidroambiental equilibrada.

A constituição física da sub-bacia não foi considerada como fator determinante nas questões hidroambientais que envolve o território. As políticas de recuperação ou revitalização ambiental devem respeitar as características naturais do meio e os agentes sociais envolvidos. Tanto o comitê de bacia hidrográfica como os solicitantes não adotaram os melhores critérios embasados nas respostas obtidas no diagnóstico ambiental realizado para SBHRC.

\section{REFERÊNCIAS}

[1] Accioly, L. J. O. et al. Mapeamento do uso e cobertura das terras do Semiárido pernambucano. Dados eletrônicos. - Rio de Janeiro, RJ: Embrapa solos, 2016. 100 p.: il. color. - (Boletim de pesquisa e desenvolvimento / Embrapa Solos, 2017. ISSN 1678-0892; 260).

[2] Agência Peixe Vivo. “Contratação de pessoa jurídica para elaboração de diagnóstico ambiental e plano de ações na bacia do rio salitre, município de jacobina, estado da Bahia”. Anexo I - termo de referência ato convocatório no 035/2016, contrato de gestão no. 14/ANA/2010. Disponível em: http://agenciapeixevivo.org.br. Acesso em 01/07/2018.

[3] “contratação de pessoa jurídica para elaboração de diagnóstico ambiental e plano de ações na bacia do rio salitre, município de jacobina, estado da Bahia". Anexo I - termo de referência ato convocatório no 031/2016, contrato de gestão no. 14/ANA/2010. Disponível em: http://agenciapeixevivo.org.br. Acesso em 01/07/2018.

[4] Botelho, R.G.M.; Silva, A. S. Bacia Hidrográfica e Qualidade Ambiental. In: Reflexões Sobre a Geografia Física no Brasil. A. C. Vitte. A. J. T. Guerra (org.). - Rio de Janeiro: Bertrand Brasil, 2004. 280p

[5] Brasil. lei no 9.433 de 08 janeiro de 1997. Institui a Política Nacional de Recursos Hídricos, cria o Sistema Nacional de Gerenciamento de Recursos Hídricos[...]. Disponível em: http://www.planalto.gov.br/CCivil_03/Leis/L9433.htm. Acesso 06/08/2018.

[6] Brito, L. T. de L., et al., 2005. Influência das atividades antrópicas na qualidade das águas da Bacia Hidrográfica do Rio Salitre. Revista Brasileira de Engenharia Agrícola e Ambiental, v.9, n.4, p.596-602, 2005.

[7] Cbhsf - Comitê da Bacia Hidrográfica do Rio São Francisco. Jacobina recebe do Cbhsf diagnóstico ambiental e plano de ações na Bacia do Rio Salitre. Jacobina 31/10/2017. Disponível em: http://cbhsaofrancisco.org.br/2017/jacobina-recebe-do-cbhsf-diagnostico-ambiental-e-plano-de-acoes-nabacia-do-rio-salitre/. Acesso em: 04/01/2018.

[8] Crepani, E. et al. Sensoriamento remoto a geoprocessamento aplicado ao Zoneamento EcológicoEconômico e ao Ordenamento Territorial. São José dos Campos, 2001. 124 p. (INPE-8454-PRQ/722).

[9] Dias, J. E; Goes, M. H. B; Silva, J. X; Gomes, O. V. O. Geoprocessamento Aplicado à Análise Ambiental: 0 Caso do Município de Volta Redonda - RJ. In: Silva, J. X.; Zaidan, R. T., (org.). Geoprocessamento e Análise Ambiental. Rio de Janeiro: Bertrand Brasil, 2004. 368 p. 
[10] Embrapa - Empresa Brasileira de Pesquisa Agropecuária. Sistema Brasileiro de Classificação de Solos. 5a ed., rev. e ampl. - Brasília, DF, 2018.

[11] Google Earth. Como as imagens são coletadas: quando as imagens são coletadas, 2017. Disponível em: <https://support.google.com/earth/answer/6327779?hl=pt-BR>. Acesso em: 04/01/2018.

[12] Guerra, A. J. T.; Mendonça, J. K. S. Erosão Dos Solos e a Questão Ambiental. In: VITTE, A. C.; Guerra, J. T., (org.). Reflexões Sobre a Geografia Física no Brasil. Rio de Janeiro: Bertrand Brasil, 2004. 280p.

[13] Ibge - Instituto Brasileiro de Geografia e Estatística, 2004. Vegetação Brasileira. Disponível em: https://www.ibge.gov.br/geociencias-novoportal/informacoes-ambientais/vegetacao. Acesso 06/08/2018.

[14] Lepsch, I. F. Formação e conservação dos solos. São Paulo (SP): Oficina de Textos, 2002. 178 p.

[15] Novo, E. M. L. de M.; Ponzoni, F. J. Introdução ao Sensoriamento Remoto. São José dos Campos - SP, 2001. Disponível em: <http://www.dpi.inpe.br/Miguel/AlunosPG/Jarvis/SR_DPI7.pdf>. Acesso em 08/01/2018.

[16] Pires, J. S. R.; Santos, J. E.; Del Prette, M. E., 2002. A Utilização do Conceito de Bacia Hidrográfica para a Conservação dos Recursos Naturais. In: Schiavetti, A.; Camargo, A. F. M. Conceitos de Bacias Hidrográficas: Teorias e Aplicações. Ilhéus, Ba: Editus, 2002. 293p.

[17] Tundisi, J. G. Recursos hídricos no futuro: problemas e soluções 2008. Disponível: http://www.scielo.br/pdf/ea/v22n63/v22n63a02.pdf. Acesso 30/07/2018.

[18] Sousa, E. J. S. Ocupação e uso do solo pela cultura do Agave sisalana no Território de Identidade do Sisal - Semiárido da Bahia. 2015. 102 f. Dissertação (Mestrado), Universidade Federal do Recôncavo da Bahia, Centro de Ciências Agrárias, ambientais e Biológicas. Cruz das Almas, BA, 2015.

[19] Vieira, A. T. et al., (org.). Projeto Cadastro de Fontes de Abastecimento por Água Subterrânea Diagnóstico do Município de Jacobina Estado da Bahia. Salvador: CPRM/Prodeem, 2005. 


\section{Capítulo 16}

Monitoramento da poluição atmosférica urbana: A relação entre as concentrações de $\mathrm{CO} 2 \mathrm{e}$ temperatura do ar na Avenida Treze de Maio, Fortaleza - CE

\section{Cristóvão Gomes}

Michael Lima Silva

Adeildo Cabral da Silva

Resumo: 0 objetivo do presente estudo foi realizar o monitoramento das concentrações de Dióxido de Carbono, temperatura e umidade do ar de uma importante avenida de Fortaleza, avaliando a relação entre esses três elementos. 0 ponto escolhido para o estudo foi a região do entorno do Instituto Federal do Ceará (IFCE), compreendida pela Avenida Treze de Maio, área central da cidade de Fortaleza, via de intenso tráfego e uma região de densa ocupação do solo, com constatação de poucas áreas verdes remanescentes. Para o monitoramento, foi implantado um sensor HOBO, modelo data logger temp/RH/2 ext channels, numa mini-estação localizado na faixada do IFCE, próximo a uma parada de ônibus, local de grande aglomeração de estudantes e pedestres. As medições se deram durante o mês de junho de 2017, começando às 05:00 da manhã até às 18:00 horas da tarde, período que abrange os principais horários de pico da cidade. Os dados coletados foram tratados e plotados em gráficos e tabelas utilizando-se o software HOBOware Pro. Esta metodologia foi a mesma utilizada por Rocha, Silva e Santos (2012). Após análise dos dados obtidos, pôde - se constatar que as mais altas concentrações diárias de $\mathrm{CO} 2$ estão diretamente ligadas às mais elevadas temperaturas do ar e ao horário maior fluxo de veículos automotores. Observou-se ainda uma tendência no aumento das concentrações de $\mathrm{CO}_{2}$ e da temperatura do ar com relação a estudos realizados por Rocha, Silva e Santos (2012) na mesma área.

Palavras-chave: Monitoramento ambiental. Dióxido de carbono. Clima Urbano. 


\section{INTRODUÇÃO}

A partir da industrialização ocorrida no século XIX e na primeira metade do século $\mathrm{XX}$, o meio urbano tornou-se alvo das mais variadas práticas modificadoras da paisagem ocasionadas pelo homem. Tornou-se comum ao ambiente citadino os grandes congestionamentos, a prevalência do concreto em detrimento das áreas verdes e a constante presença de comércios e indústrias que tornam os espações cada vez mais ocupados.

A introdução de materiais escuros e impermeáveis (asfalto, concreto) e a contínua verticalização das edificações são fatores que contribuem para o desconforto térmico do ambiente das grandes cidades. Soma-se a isso, o alto número de veículos automotores circulando, que além do ruído, lançam poluentes que repercutem na baixa qualidade do ar.

Um dos poluentes que mais preocupam do ponto de vista ambiental é o dióxido de carbono (CO2), pois contribui para os baixos índices de qualidade do ar e para o desequilíbrio climático.

0 ser humano é responsável por aproximadamente 78\% do gás carbônico presente na atmosfera, que é emitido, principalmente pela queima de combustíveis fósseis nas atividades humanas (GASES... 2014). No ambiente urbano, o aumento da frota de veículos automotores tem sido uma das principais fontes de emissão de dióxido de carbono.

Uma característica importante do CO2 é que ele tem a capacidade de absorver a radiação solar e aquecer a atmosfera. Esse fator desperta a preocupação da sociedade e dos pesquisadores, visto que as concentrações desse gás só aumentam a cada dia, podendo levar ao agravamento do aumento da temperatura nos microclimas urbanos.

Dentre os efeitos diretos do aumento da temperatura está o desconforto térmico, que repercute na redução do desempenho humano em diversas atividades diárias, no aumento do consumo de energia em climatização artificial e consumo de água para hidratação humana.

Estudos sobre o tema sempre realizam uma contextualização da evolução urbana e suas implicações ambientais. A cidade de Fortaleza apresentou nas últimas décadas um intenso processo de urbanização (LOPES, 2010) que trouxe consigo atividades que contribuíram para o desequilíbrio de diversos aspectos ambientais.

Com uma frota de pouco mais de 1 milhão de veículos (DETRAN-CE, 2017) e com áreas verdes cada vez mais escassas, a paisagem urbana da cidade constitui um cenário alterado onde se deve estudar os impactos ambientais gerados.

\section{OBJETIVO}

O presente estudo tem o objetivo de realizar o monitoramento das concentrações de dióxido de carbono, temperatura e umidade do ar em uma importante Avenida de Fortaleza, a fim de avaliar o conforto térmico humano dessa região, verificar possíveis tendências nas concentrações de $\mathrm{CO} 2$ e temperatura em relação à estudos anteriores e às normais climatológicas.

\section{METODOLOGIA}

O Município de Fortaleza, capital do Estado do Ceará, Brasil, situa-se na porção nordeste do estado, nas coordenadas de latitude sul: $3^{\circ} 43^{\prime} 2^{\prime \prime}$ e longitude oeste: $38^{\circ} 32^{\prime} 35^{\prime \prime}$. 
Figura 1 - Localização da cidade de Fortaleza no Brasil.

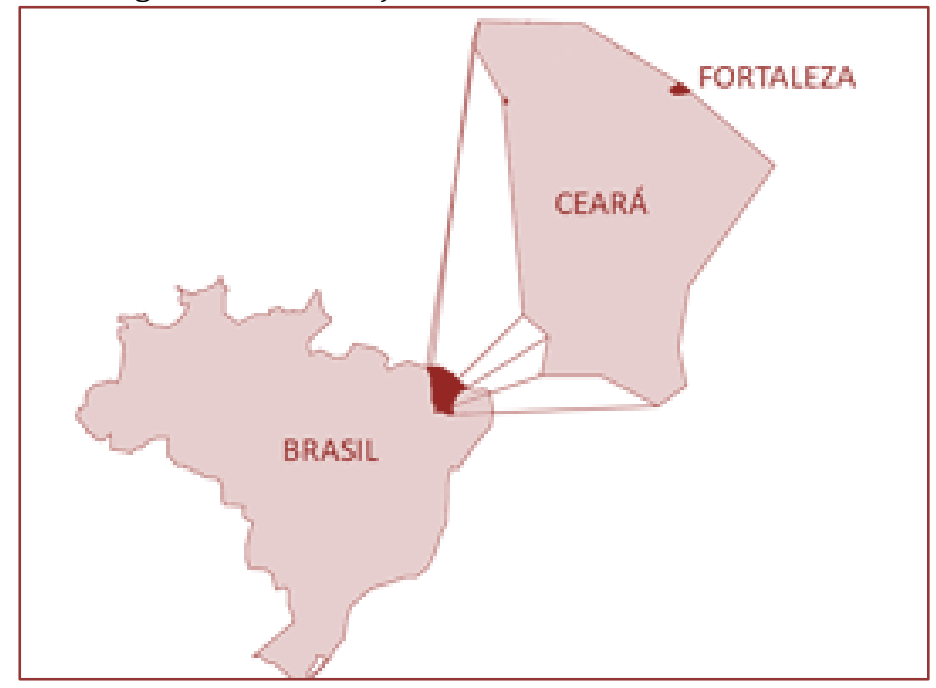

Fonte: Autor

No que tange à localização para o monitoramento, foi escolhida a Avenida Treze de Maio, via de intensa urbanização e um importante corredor de atividades da área urbana da cidade.

Convém salientar que esta avenida está entre os corredores de maior circulação de veículos da cidade. Num ranking sobre as avenidas mais movimentadas da cidade realizado em 2015, essa via ocupava $9^{\circ}$ posição, com uma média de 43.459 veículos circulando por dia.

Figura 2 - Ranking das vias de maior fluxo de veículos de Fortaleza em 2015.

\begin{tabular}{|lcr|}
\hline 2015 & & \\
$1^{\circ}$ & Av. Aguanambi & 63.455 \\
$2^{\circ}$ & Av. Washington Soares (CE-040) & 60.000 \\
$3^{\circ}$ & Av. Domingos Olimpio & 50.949 \\
$4^{\circ}$ & Av. Eng० Santana Jünior & 49.316 \\
$5^{\circ}$ & Av. Bezerra de Menezes & 48.837 \\
$6^{\circ}$ & Av. Raul Barbosa & 47.838 \\
$7^{\circ}$ & Av. Aboliça & 47.434 \\
$8^{\circ}$ & Av. Borges de Melo & 45.765 \\
$9^{\circ}$ & Av. 13 de Maio & 43.459 \\
$10^{\circ}$ & Av. Oliveira Paiva & 41.090 \\
\hline
\end{tabular}

Fonte: Bezerra, 2016.

$\mathrm{O}$ ponto onde ocorreu o monitoramento do $\mathrm{CO}_{2}$ e temperatura foi o Instituto Federal do Ceará, campus Fortaleza, localizado na porção central da Av. Treze de Maio, 2081 bairro de Fátima. 
Figura 3 - Localização do ponto de monitoramento

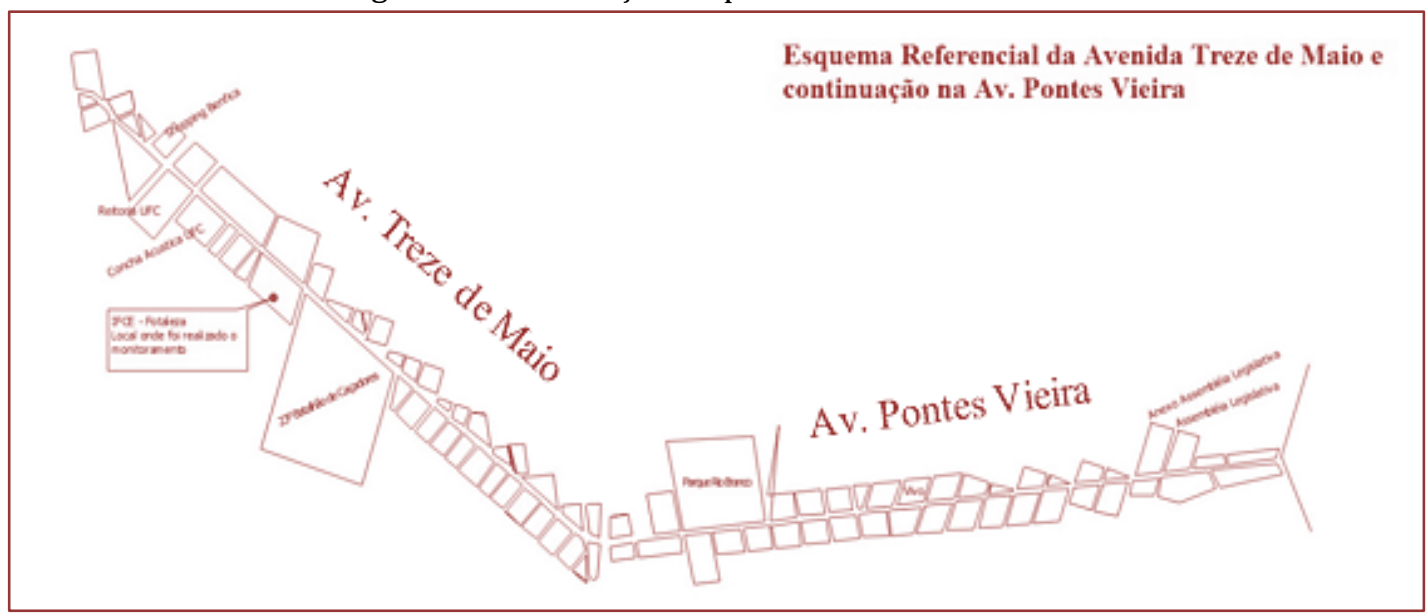

Fonte: Elaborado pelos autores, 2017.

Para tal, foi implantado um sensor HOBO, modelo data logger temp/RH ext channels, que ficou abrigado numa mini-estação de monitoramento automático (Figura 4), localizado na faixada do IFCE próximo a uma parada de ônibus, local de grande aglomeração de estudantes e pedestres.

As medições se deram durante o mês de junho de 2017, começando às 05:00 da manhã até às 18:00 horas da tarde de cada dia, período que abrange os principais horários de pico da cidade, que são: pico da manhã (06:30 a 08:30), meio dia (11:30 a 13:30) e final da tarde (17:30 a 19:30) (CEARÁ, 2012).

Figura 4 - Sensor automático de $\mathrm{CO}_{2}$ e temperatura e Umidade Relativa do Ar (à esquerda) e miniestação de monitoramento localizada na faixada do IFCE - Fortaleza (à direita).

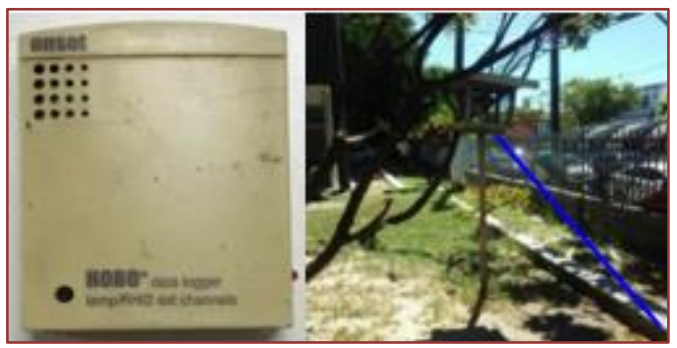

Fonte: Autor, 2017

Durante a coleta de dados, foram registrados valores de $\mathrm{CO}_{2}$ em partículas por milhão (ppm), temperatura do ar em ${ }^{\circ} \mathrm{C}$ e umidade relativa do ar em porcentagem (\%). Em posse dos dados de temperatura e umidade do ar foram calculados o Índice de Conforto Térmico Humano (ICTH) e o Índice de Desconforto Humano (IDH).

O ICTH foi calculado tendo como referência a fórmula descrita por Anderson (1965), citada por Rosemberg (1983) e Santos e Melo (2010):

$$
I C H=T_{a}+\frac{5}{9}\left(e_{a}-10\right)
$$


Para a qual $\mathrm{T}_{\mathrm{a}}$ é a temperatura do ar em graus Celsius; $\mathrm{e}_{\mathrm{a}}$ é a pressão de vapor que pode ser calculada do seguinte modo:

$$
e_{a}=\frac{\left(e_{S} * U R\right)}{100}
$$

Na qual $e_{s}$ é a pressão de vapor do ar saturado e pode ser calculada usando a equação de Tetens (1973):

$$
e_{S}=6,10 \times 10^{\left[\frac{(7,5 * T a)}{237,3+T_{a}}\right]}
$$

Na Tabela 1 encontra-se a classificação do grau de conforto térmico em função dos valores de ICH obtidos.

Tabela 1 - Índices de Conforto Térmico Humano

\begin{tabular}{|c|c|c|c|}
\hline ICTH & Graus de Conforto & ICTH & Graus de Conforto \\
\hline $20-29$ & Confortável & $40-45$ & Desconforto Suportável \\
\hline $30-39$ & $\begin{array}{c}\text { Graus de conforto } \\
\text { variando }\end{array}$ & 46 ou mais & Desconforto insuportável \\
\hline
\end{tabular}

Fonte: Adaptado de Santos e Melo (2010).

O Índice de Desconforto Humano (IDH) foi calculado pela fórmula descrita por Ono e Kawamura (1991), sendo Ta a temperatura do ar e Td a temperatura de orvalho.

$$
\mathrm{IDH}=0,99 \mathrm{~T}_{\mathrm{a}}+0,36 \mathrm{~T}_{\mathrm{d}}+41,5
$$

Td pode ser estimada de acordo com a equação:

$$
T d=\frac{b x \alpha(T a, U R)}{a-\alpha(T a, U R)} \quad \alpha(T a, U R)=\frac{a x T a}{b+T a}+\ln (U R)
$$

Sendo que: $\mathrm{a}=17,27$ e $\mathrm{b}=237,7\left({ }^{\circ} \mathrm{C}\right)$ e UR é a umidade relativa dividida por 100 (cem).

As faixas de valores do índice de desconforto de humano (IDH) relativas às condições de conforto térmico sentidos pelas pessoas (ONO e KAWAMURA, 1991) estão descritas na Tabela 2.

Tabela 2 - Índices de Conforto Térmico Humano

\begin{tabular}{|c|l|}
\hline \multicolumn{1}{|c|}{ Intervalo do IDH } & \multicolumn{1}{c|}{ Efeito } \\
\hline Acima de 80 & Estresse devido ao calor \\
\hline $75-80$ & Desconfortável devido ao calor \\
\hline $60-75$ & Confortável \\
\hline $55-60$ & Desconfortável devido ao frio \\
\hline Abaixo de 55 & Estresse devido ao frio \\
\hline
\end{tabular}

Fonte: Adaptado de Santos e Melo (2010). 


\section{ANÁLISE E DISCUSSÃO DOS RESULTADOS}

Os dados recolhidos com o monitoramento do $\mathrm{CO}_{2}$ e da temperatura in situ permitem compreender, em pormenor e com rigor, o comportamento dessas variáveis na avenida monitorada. 0 gráfico a seguir mostra um panorama geral da variação desses elementos durante o mês de junho de 2017.

Figura 5 - Concentrações de $\mathrm{CO}_{2}$ e níveis de temperatura em junho de 2017.

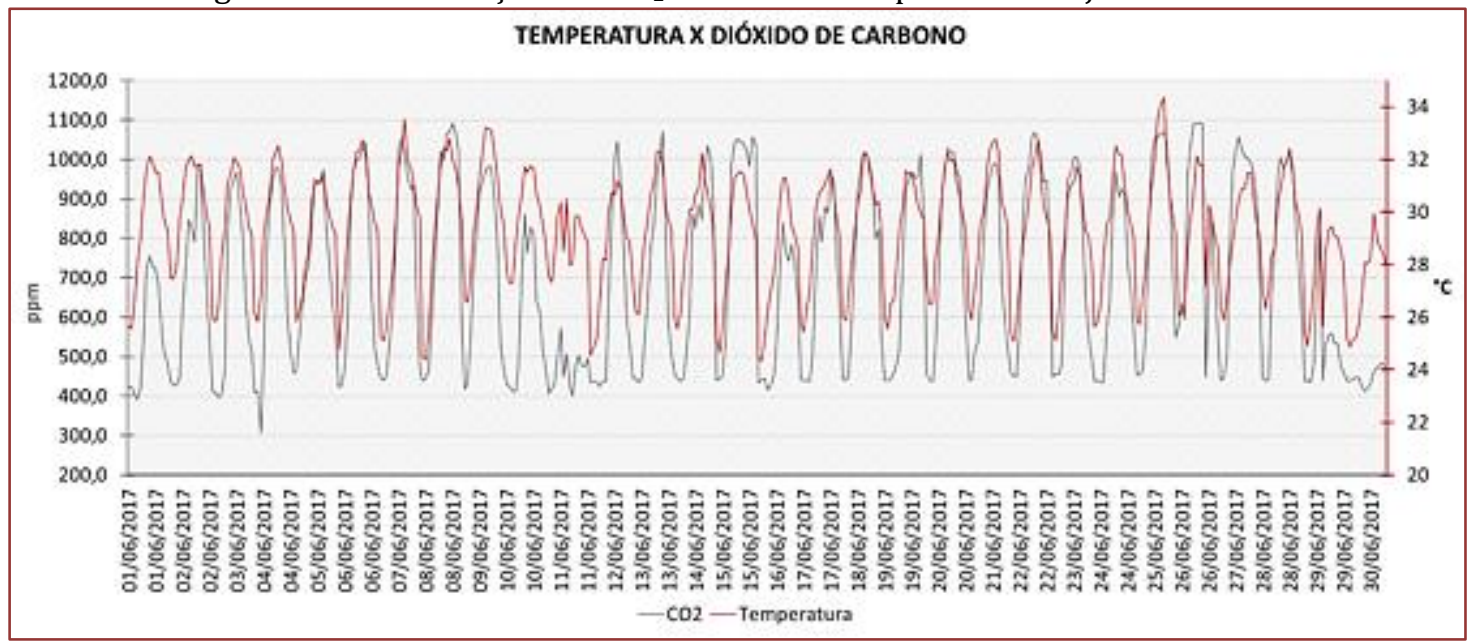

Fonte: Autor, 2017

O dia que mais se destacou foi 25 de junho de 2017, onde o nível de $\mathrm{CO}_{2}$ atingiu a marca de 1069,0 ppm às 14 horas, quando ocorreu também a temperatura de $34,36^{\circ} \mathrm{C}$, máxima concentração de $\mathrm{CO}_{2}$ e temperatura registrados durante o monitoramento.

Figura 6 - Concentrações de $\mathrm{CO}_{2}$ e níveis de temperatura no dia 25/06/2017

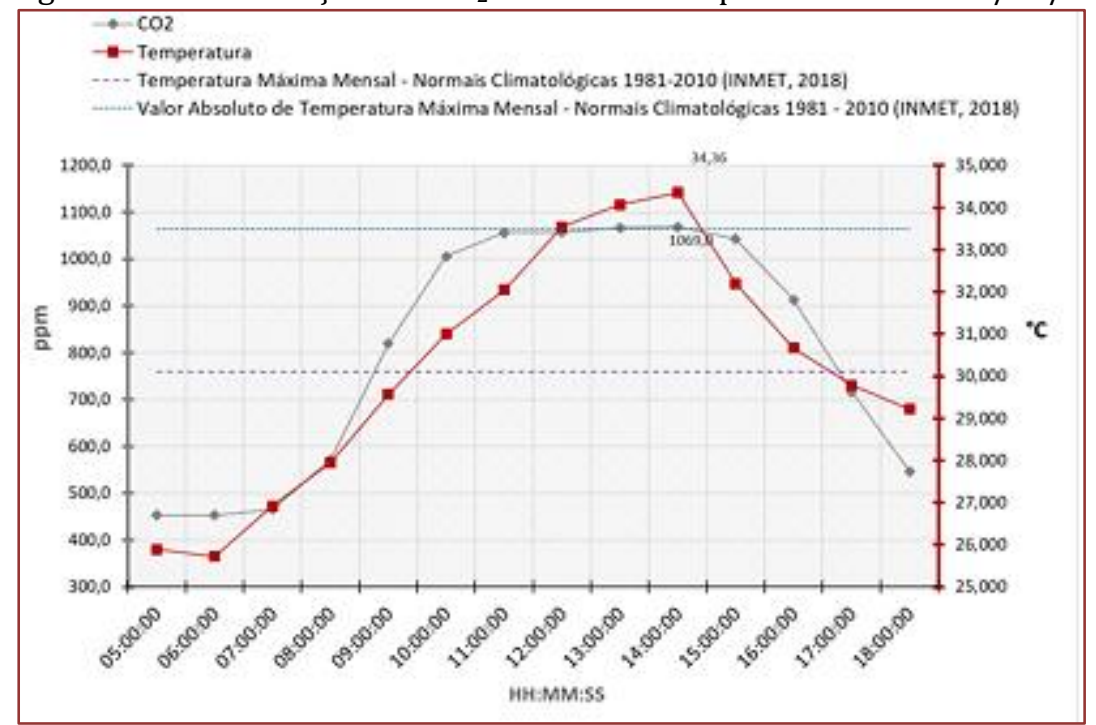

Fonte: Autor, 2017.

A figura 6 mostra a relação entre os níveis de $\mathrm{CO}_{2}$ com a temperatura do ambiente, iniciando o dia com níveis baixos das duas variáveis, aumento ao longo do dia até chegar ao registro máximo às 14:00 h. Essa elevação coincide com o horário de pico da tarde, onde é verificado intenso transito de veículos automotores, principais emissores de $\mathrm{CO}_{2}$. Os valores começam a decrescer logo após o pico observado à tarde. 
O gráfico nos mostra também que a temperatura máxima registrada pelo sensor no dia 25 de junho é maior do que a temperatura máxima mensal $\left(30,1^{\circ} \mathrm{C}\right)$ já registrada entre 1981 - 2010 e o valor absoluto de temperatura máxima mensal $\left(33,5^{\circ} \mathrm{C}\right)$ registrado em 2010.

No estudo realizado por Rocha, Silva e Santos (2012) no mesmo ponto da Avenida Treze de Maio, os registros de $\mathrm{CO}_{2}$ e temperatura apresentaram comportamento semelhante. Na ocasião, o dia 2 de janeiro apresentou máxima concentração de $\mathrm{CO}_{2}$ de $650 \mathrm{ppm}$, com a temperatura de $31^{\circ} \mathrm{C}$, às 13 horas e no dia 7 de fevereiro, a máxima concentração de $\mathrm{CO}_{2}$ chegou a 664 ppm, com temperatura de $31^{\circ} \mathrm{C}$, às 14 horas.

Tabela 03 - Comparação entre os registros de temperatura e $\mathrm{CO}_{2}$ de 2012 e 2017

\begin{tabular}{|c|c|c|c|}
\hline & $\begin{array}{l}\text { Rocha, Silva e Santos } \\
2012\end{array}$ & $\begin{array}{c}\text { Gomes, Silva e Silva } \\
2017\end{array}$ & Variação \\
\hline $\mathrm{CO}^{2}$ & $\begin{array}{l}650 \mathrm{ppm} \\
664 \mathrm{ppm}\end{array}$ & 1069 ppm & $\begin{array}{l}419 \mathrm{ppm} \\
405 \mathrm{ppm}\end{array}$ \\
\hline Tc & $\begin{array}{l}31{ }^{\circ} \mathrm{C} \\
31{ }^{\circ} \mathrm{C}\end{array}$ & $34,36 \circ \mathrm{C}$ & $3,36 \circ \mathrm{C}$ \\
\hline
\end{tabular}

Fonte: Autor, 2017

Conforme visto na tabela 03, houve diferenças significativas nas concentrações de dióxido de carbono entre os registros de 2012 e 2017. A maior variação entre esses dois episódios foi de 419 ppm, o que sugere que nesse intervalo de tempo as concentrações desse gás recrudesceram, muito provavelmente pelo aumento do número de veículos que circulam na área estudada. As temperaturas do ar seguiram a mesma tendência de aumento verificados no $\mathrm{CO}_{2}$, de forma que a variação entre os dois episódios foi de $3,36^{\circ} \mathrm{C}$.

Percebe-se com isso, certa relação entre as concentrações de $\mathrm{CO}_{2}$ e temperatura, de tal forma que se as concentrações desse gás aumentam, as temperaturas seguem a mesma tendência, além de se ter constatado também que as maiores temperaturas encontradas tanto em 2012, como em 2017, deram-se no momento em que se registraram as maiores concentrações de dióxido de carbono.

Com relação à umidade do ar, durante o mês de monitoramento as médias diárias ficaram na faixa entre $60 \%$ e 75\%, abaixo das normais climatológicas para o mês que é de 80,6\% (INMET, 2018).

Figura 7 - Níveis de temperatura e umidade na Avenida Treze de Maio em junho de 2017.

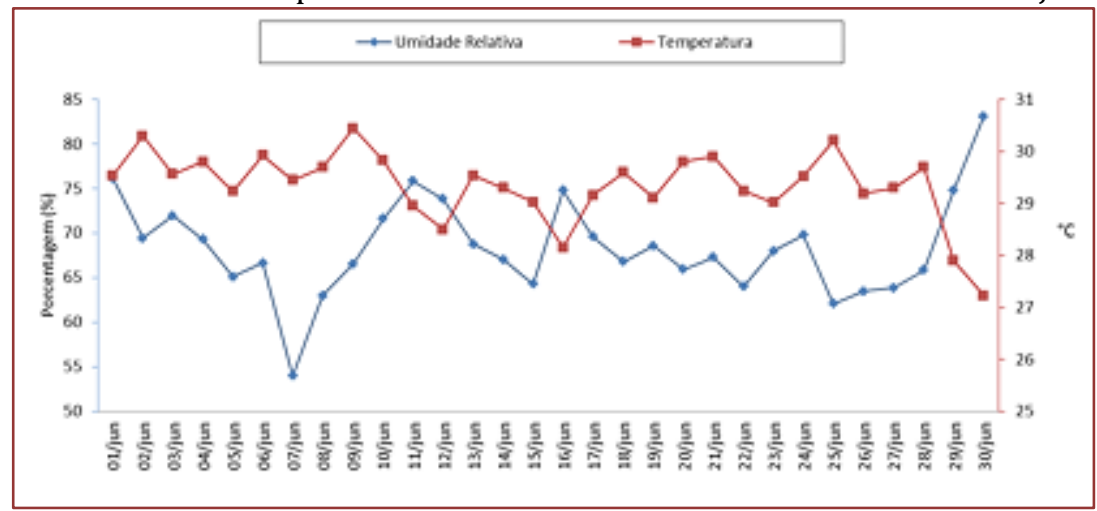

Fonte: Autor, 2017.

Apenas o dia 7 apresentou valores baixos umidade relativa do ar, chegando a valores próximos aos $30 \%$, teor de umidade classificado como estado de atenção pela Organização Mundial da Saúde (OMS). Em média, o mês de junho apresentou temperaturas altas acima das normais $\left(26,1^{\circ} \mathrm{C}\right)$. 
No que diz respeito ao Conforto Térmico Humano, os resultados obtidos a partir das médias diárias de temperatura e umidade relativa do ar compreendendo todo o mês de junho de 2017 estão expostos no gráfico a seguir.

Figura 8 - índice de Conforto Térmico Humano durante o Monitoramento.

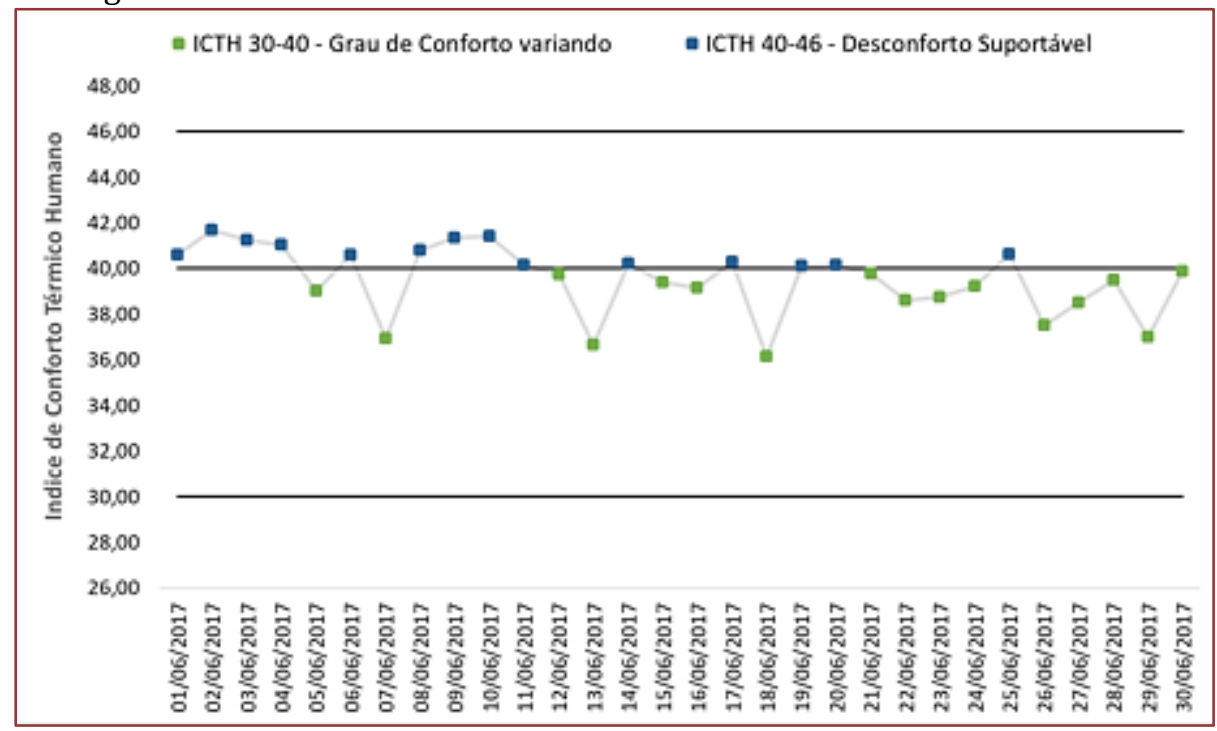

Fonte: Autor, 2017.

Analisando o gráfico, percebe-se que com valor de ICTH variando entre 40 e 45 na maioria dos de junho de 2017, mostram que o ponto da avenida monitorado apresento desconforto suportável. As únicas exceções foram os dias 7, 13,22,26 e 29, que apresentaram graus de conforto variando.

Também com as médias diárias de temperatura e umidade relativa do ar, calculou-se o índice de desconforto humano (IDH) e os resultados obtidos estão descritos no gráfico a seguir.

Figura 9 - índice de Desconforto Humano durante o Monitoramento.

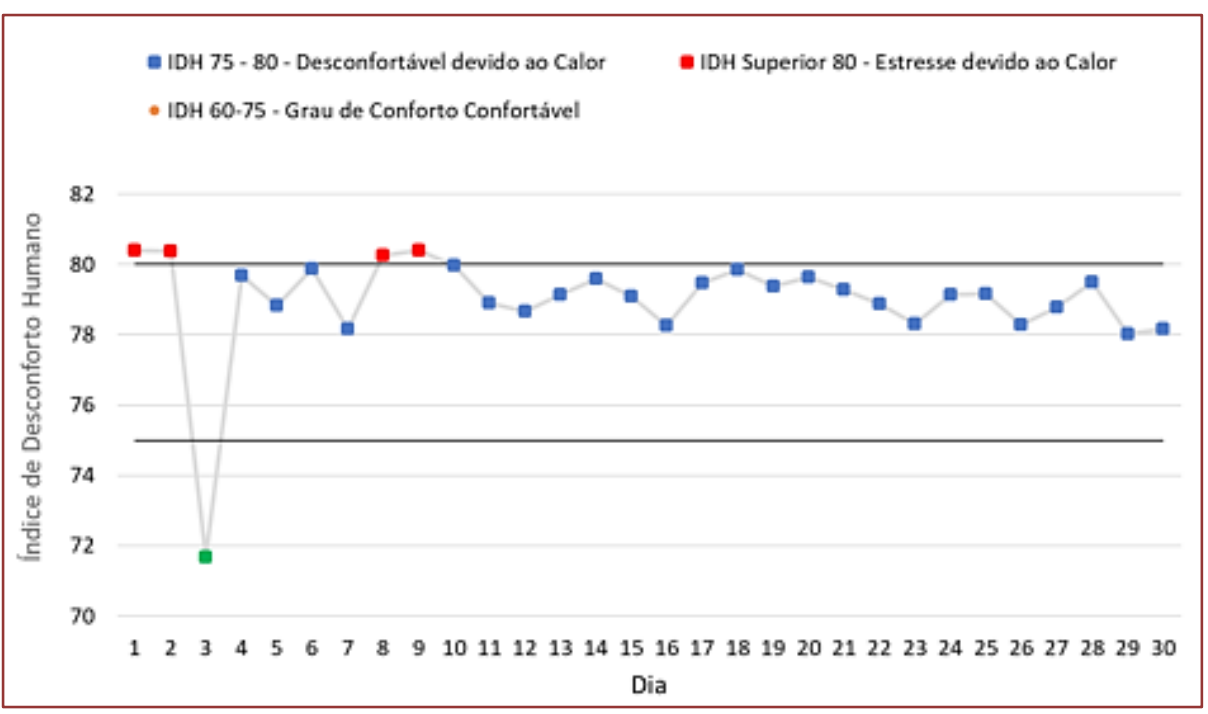

Fonte: Autor, 2017.

Analisando os dados com esse segundo índice, constatou-se que a maioria dos dias monitorados apresentaram valor de IDH variando entre 75 e 80, índice considerado desconfortável devido ao calor. É importante destacar que os dias 1, 2, 8 e 9 apresentaram os maiores índices (IDH maior que 80), classificando o ponto estudado, nesses três dias específicos, como um ambiente que proporciona estresse devido ao calor. 


\section{CONSIDERAÇÕES FINAIS}

O clima exerce influência sobre o homem, assim como o homem desempenha um papel importante na dinâmica climática através de suas atividades.

Com o presente estudo constatou-se que os valores de temperatura levantados se estabeleceram distantes da média prevista pelas normais climatológicas para o mês de junho de $2017\left(26,1^{\circ} \mathrm{C}\right)$, e observou-se uma tendência no aumento das concentrações de $\mathrm{CO}_{2}$ e temperatura do ar com relação ao estudo realizado por Rocha, Silva e Santos (2012) e às normais climatológicas.

A umidade relativa do ar encontrada no trecho estudado se apresentou abaixo das normais para mês de junho (80,6\%), contudo ainda apresentando teores adequados, na faixa entre $60 \%$ e $75 \%$. Esses valores se mostraram estáveis devido à localização litorânea da cidade próxima ao oceano, que exerce influência na umidade da cidade.

No tocante ao conforto dos pedestres, verificou-se com a aplicação dos dois índices que nenhum dos dias monitorados apresentaram condições que classificassem o ambiente como confortável do ponto de vista térmico.

Convém reiterar que na área do monitoramento existem equipamento de grande circulação e aglomeração de pessoas, como calçadas, comércios, Instituição de ensino e paradas de ônibus. Dessa forma, os dados apresentados pelo estudo mostram que o uso e a ocupação do solo dessa área, com o emprego de materiais escuros e impermeáveis, bem como a diminuição das áreas verdes que hoje se limitam ao canteiro central da avenida, oferecem um ambiente desconfortável que faz com que a locomoção e a espera por transporte dos pedestres sejam desagradáveis.

\section{BIBLIOGRAFIA}

[1] Brasil. Instituto Nacional de Meteorologia; Ministério da Agricultura, Pecuária e Abastecimento. Normais Climatológicas do Brasil (1981-2010). Brasília, 2018.

[2] Bezerra, R. Frota de veículos de Fortaleza é a maior da região Nordeste. Diário do nordeste. Fortaleza, 22 de abril de 2016. Disponível em: <https://goo.gl/thApiU>. Acesso em: 17 de jun. 2017.

[3] Detran-CE, Depatamento Estadual de Trânsito do Ceará. Estatísticas. 2017. Disponível em < https://goo.gl/eD8cUh>. Acesso em 25 de fev. de 2018.

[4] Lopes, W.M.; Cabral da Silva, A.; Silva, N.M. Clima Urbano: Monitoramento da temperatura e da umidade da avenida Treze de Maio, Fortaleza - CE. In: V Connepi, 2010, Alagoas. Anais... Alagoas: V Connepi, 2010.

[5] Gases do efeito estufa: Dióxido de Carbono (CO2) e Metano (CH4). Dicionário Ambiental. ((o))eco, Rio de Janeiro, abr. 2014. Disponível em: <https://goo.gl/7uizYz> Acesso em: 17 de jun. 2017.

[6] Ono, H. S. P.; Kawamura T. (1991). Sensible Climates in Monsoon Asia. International Journal of Biometeorology, Vol. 35, n XX, pp. 39-47

[7] Pinheiro, K. AMC lista vias de maior fluxo em fortaleza. Diário do nordeste. Fortaleza, 13 de janeiro de 2012. Disponível em: <https://goo.gl/QN4wKu>. Acesso em 09 de jun. 2017.

[8] Rocha, N.N; Silva, A.C; Santos, P.G.L. Estudo sobre a influência do gás dióxido de carbono em relação à temperatura diária na Avenida Treze de Maio, Fortaleza - Ceará. In: Congresso Norte Nordeste de Pesquisa e Inovação., 7., 2012, Palmas. Anais... Palmas: IFCE, 2012.

[9] Silva, J.B; Cavalcante, T.C. Atlas Escolar do Ceará: Espaço Geo-Histórico e Cultural. 2. ed. João Pessoa: Grafset, 2004. 200p. 


\section{Capitulo 17}

Análise dos elementos climatológicos e casos de enchentes como forma de compreender a proliferação do mosquito Aedes Aegypti: 0 caso do perímetro urbano de Marabá-Pará.

\section{Athos Ricardo Souza Lopes}

Marley Trajano Lima

Gustavo da Silva

Resumo: A cidade de Marabá-Pará passa pelo fenômeno das cheias todos os anos. Com isso, o presente trabalho busca apresentar os dados pluviométricos de 2007 a 2016 e relacionar com os fenômenos das enchentes e, posteriormente, com os casos de dengue na cidade.

As epidemias de dengue ocorrem no período mais quente do ano. Os meses de dezembro, janeiro, fevereiro, março e começo de abril, são os períodos em que os níveis pluviométricos e a média da temperatura máxima estão em alta, aumentando a taxa de metabolismo do vetor e reduzindo o ciclo evolutivo em até 8 dias, no período mais frio o ciclo chega a 22 dias.

Dessa forma o estudo mostra que a proliferação do Aedes aegypti está associada aos fatores climáticos de temperatura e precipitação, ou seja, temperatura máxima e umidade relativa do ar contribuem diretamente para o aumento desse fenômeno. 


\section{INTRODUÇÃO}

Por conta do crescente histórico migratório de pessoas advindas de outras localidades do estado e até mesmo do país, Marabá vem se tornando uma cidade requisitada desde o ciclo da borracha, passando pelo boom da castanha, instalação de grandes empreendimentos até chegar no mercado que tem hoje, uma economia forte voltada primordialmente para o setor de serviços, indústria e agropecuária.

Conforme a cidade ia crescendo seus núcleos foram se expandindo, onde o primeiro local a ser ocupado foi o burgo do Itacaiúnas, pois era onde ocorria as vendas e trocas de diversos produtos. Contudo, quando alguns viajantes decidiram fixar-se ali, a cidade começou a se expandir rapidamente, ocasionando o aumento da população local. Nos dias de hoje ainda há pessoas morando no burgo do rio, mesmo sabendo que o local foi decretado como área de risco. Ao que se pode constatar é que a permanência nesse local está associada ao valor histórico e sentimental que cada morador tem, pois, os mesmos já têm uma dinâmica de vivência com o rio.

O estudo sobre as enchentes da microrregião de Marabá-PA vem sendo feita a anos por geógrafos, sociólogos e historiadores ao longo das décadas, buscando mostrar a relação entre sociedade e natureza e de que forma esse elo de ligação continua forte por todo esse tempo. 0 presente trabalho tem como objetivo apresentar os dados pluviométricos dos anos de 2006 a 2017 e relacionar com os casos de proliferação do mosquito da dengue através de análise de dados climáticos da cidade de Marabá-PA.

\section{LOCALIZAÇÃO DA ÁREA DE ESTUDO}

O município de Marabá está localizado na microrregião de Marabá, Sudeste Paraense, no estado do Pará, no Brasil. Nas coordenadas geográficas: 05o 22' 07" S de latitude e 49o 07' 04" W de longitude. Está a cerca de 500 quilômetros ao sul da capital do estado. Sua localização tem, por referência, o ponto de encontro entre dois grandes rios, Tocantins e Itacaiúnas, formando uma espécie de "y" no seio da cidade vista de cima. É formada basicamente por seis distritos urbanos interligados por rodovias, com uma população estimada de 271.594 habitantes.

Mapa 01: Localização do perímetro urbano da cidade de Marabá-PA. Fonte: IBGE (2010) - DNIT. Elaboração: LOPES, A.R.S

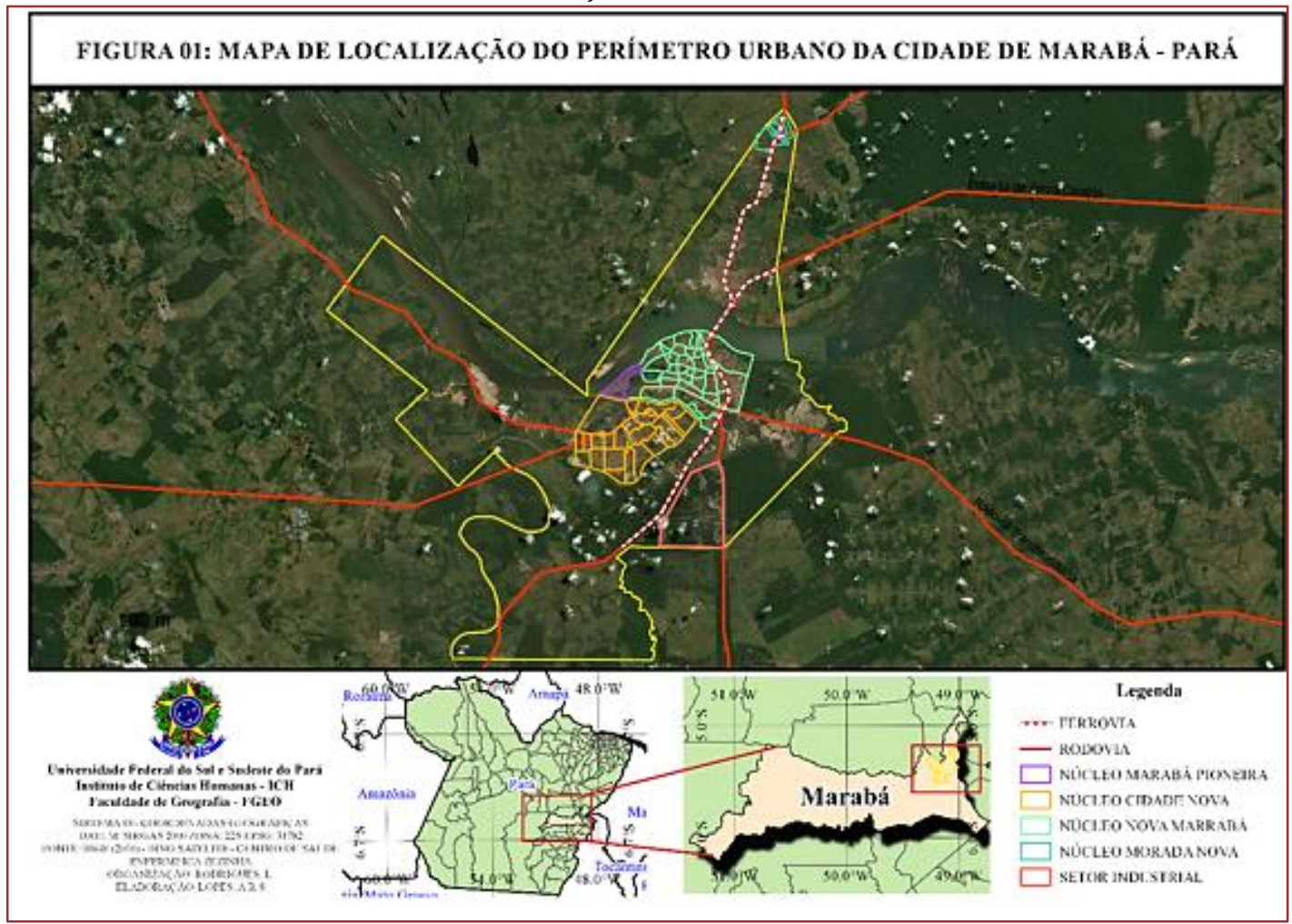




\section{SITUAÇÃO DE RISCO}

A cidade de Marabá-PA está circundada pelos rios Tocantins e Itacaiúnas, nos quais têm dinâmicas de cheia anualmente. A ocorrência desse fenômeno está entre os meses de dezembro a abril, nesse período a prefeitura em conjunto com diversos órgãos como Corpo de Bombeiros, Defesa Civil e até o Exército Brasileiro, montam uma força tarefa para remanejar os moradores dessas áreas de risco para áreas seguras.

Pelo fator histórico do crescente processo de expansão desordenada da cidade, alguns moradores arriscam a habitar-se nessas áreas de risco de inundação, ou seja, à margem dos rios. Por conta da identidade cultural e histórica com o local, esses moradores tendem a voltar para essas áreas, mesmo sabendo da sua condição de risco. Outro motivo para esse retorno seria o trabalho com a pesca, pois muitos desses moradores já estão em idade avançada e só tem o pescado como fonte de alimento e renda.

\section{MATERIAIS E MÉTODOS}

Utilizando a metodologia observativa, sistemática e dedutiva, foram coletados dados pluviométricos do site INMET dos anos de 2007 a 2016, após isso houve o ajuste e tratamentos desses dados coletados. Com as informações no programa EXCEL, esses dados foram filtrados e analisados por data (ano e mês), onde cada mês de todos os anos foi colocado em uma nova planilha. Utilizamos os dados de precipitação, temperatura máxima, temperatura média, insolação, evaporação, umidade relativa do ar e velocidade do vento. Para calcular o total de precipitação em um determinado mês utilizamos a fórmula de soma (=SOMA), após isso abrimos parênteses e colocamos a letra e o número da primeira e última coluna com os dados de precipitação, separandoas pelo sinal de dois pontos, ficando como no exemplo: =SOMA (D2: D1923).

Ficando assim:

Figura 01: Configuração dos dados meteorológicos para a confecção dos gráficos estatísticos. Elaboração: LOPES, A.R.S.

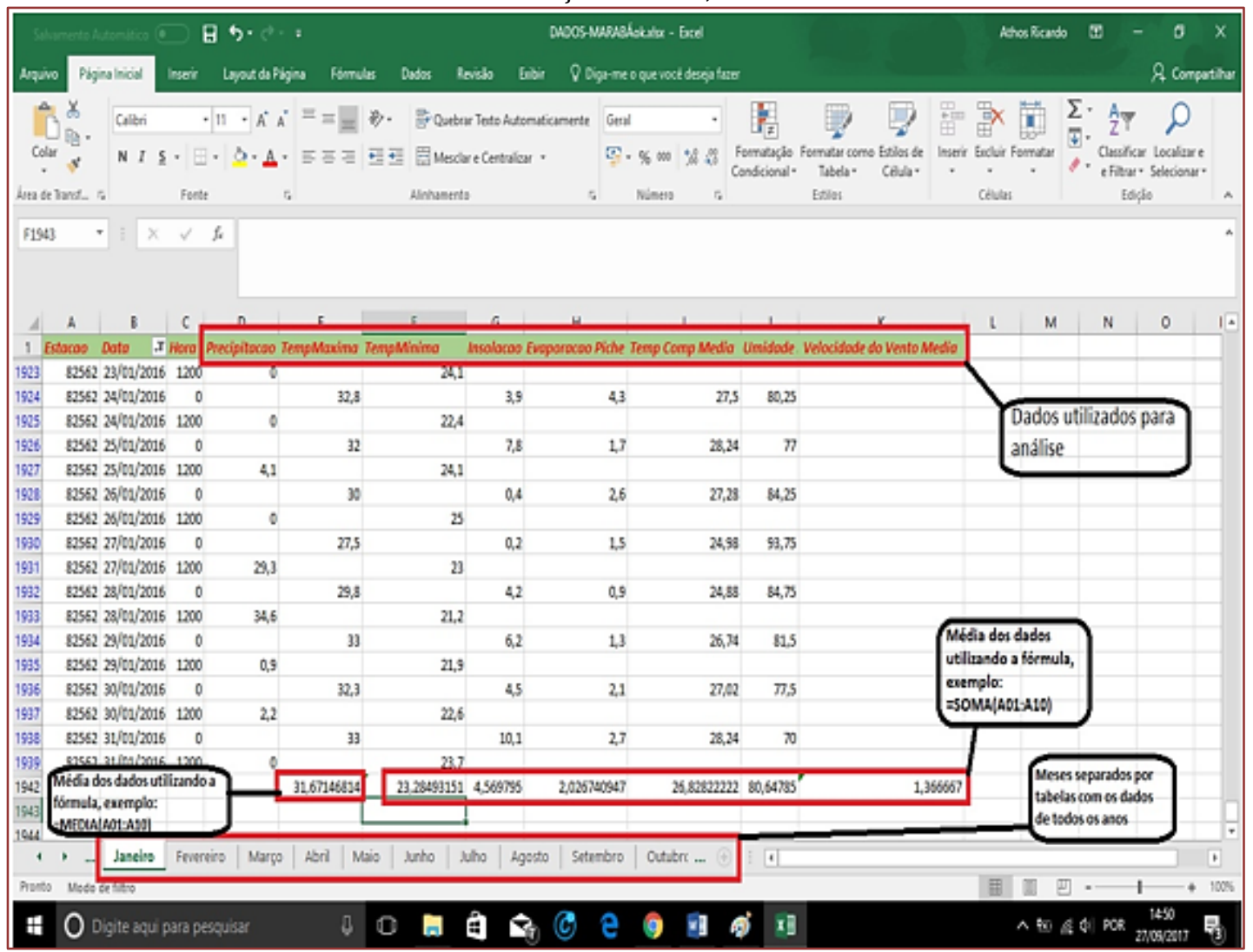


Esta formula irá selecionar todas os dados referentes a precipitação. Para os dados de temperatura máxima, temperatura média, insolação, evaporação, umidade relativa do ar e velocidade do vento foi utilizado a fórmula de média (=MEDIA), que tem o mesmo padrão da fórmula anterior, porém, esta agora irá calcular a média dos dados selecionados. Após a formatação dos dados climáticos foram feitos gráficos com as somas e as médias adquiridas com as fórmulas.

Para a confecção dos mapas foi utilizado o Software QGIS 2.18.12, e para a formatação das planilhas e dos gráficos foi utilizado o software Office Excel.

\section{RESULTADOS E DISCUSSÕES}

Durante vários anos a população vem enfrentando inundações extremas ocasionando em pessoas desabrigadas e até mortes. Mesmo sabendo desse risco os moradores estavam "predispostos à luta que sabiam ser difícil, em mutirões reconstruíram suas casas bem melhores nos mesmos locais ainda umedecidos pelas águas que por ali fizeram caminho, deixando rasto lamacento e pútrido" (MONTEIRO, 2002: 44). Dessa forma, o presente estudo busca apresentar os dados pluviométricos dos anos de 2006 a 2017 e relacionar com os casos de proliferação do mosquito da dengue através de análise de dados epidemiológicos da cidade de Marabá-PA.

A partir da análise dos dados, temos os resultados de precipitação anual do município. Como apresentando nos gráficos seguintes:

Figura 02: Meses com dados de precipitação do ano de 2007.

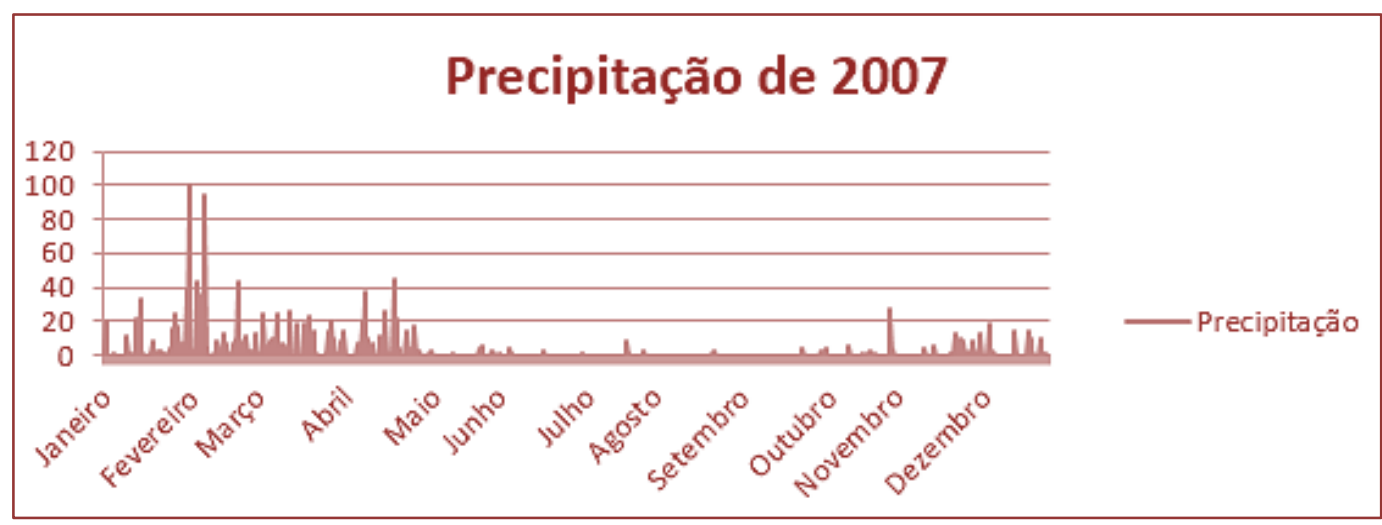

Fonte: INMET.

No ano de 2007 os meses de maior precipitação foram fevereiro e março, no qual fevereiro chegou a marcar $100 \mathrm{~mm} /$ dia.

Figura 03: Meses com dados de precipitação do ano de 2008.

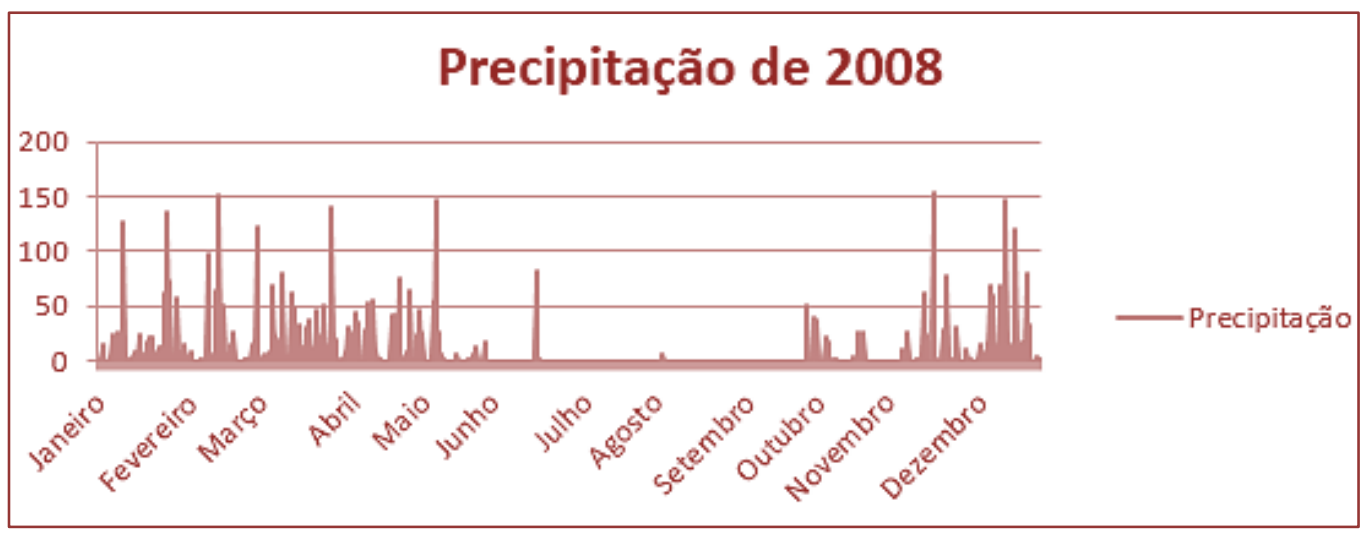

Fonte: INMET. 
Em 2008 os índices de precipitação de todo o período chuvoso da cidade marcaram acima de 100 $\mathrm{mm} /$ dia, e os meses com maior quantidade de chuvas foram os de fevereiro e novembro, chegando até $153 \mathrm{~mm} /$ dia.

Figura 04: Meses com dados de precipitação do ano de 2009.

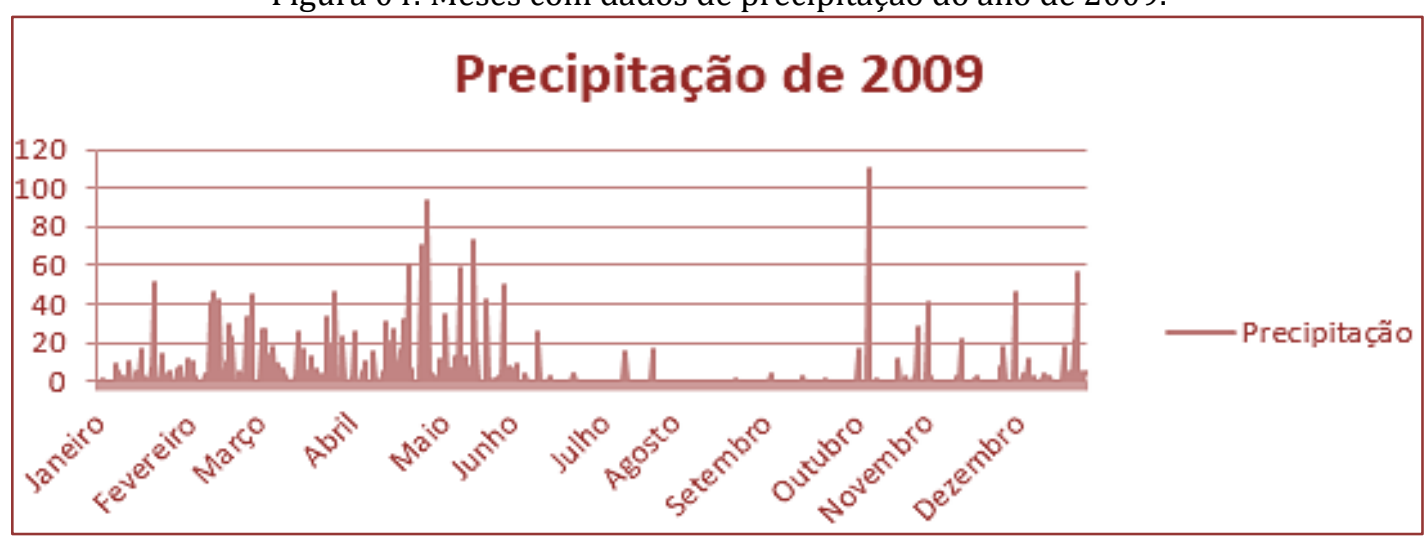

Fonte: INMET.

Em 2009 a precipitação média ficou entre 60 e $80 \mathrm{~mm} /$ dia, e o período de maior precipitação foram os meses de abril e outubro, com 95 e $110 \mathrm{~mm} /$ dia, respectivamente.

Figura 05: Meses com dados de precipitação do ano de 2010.

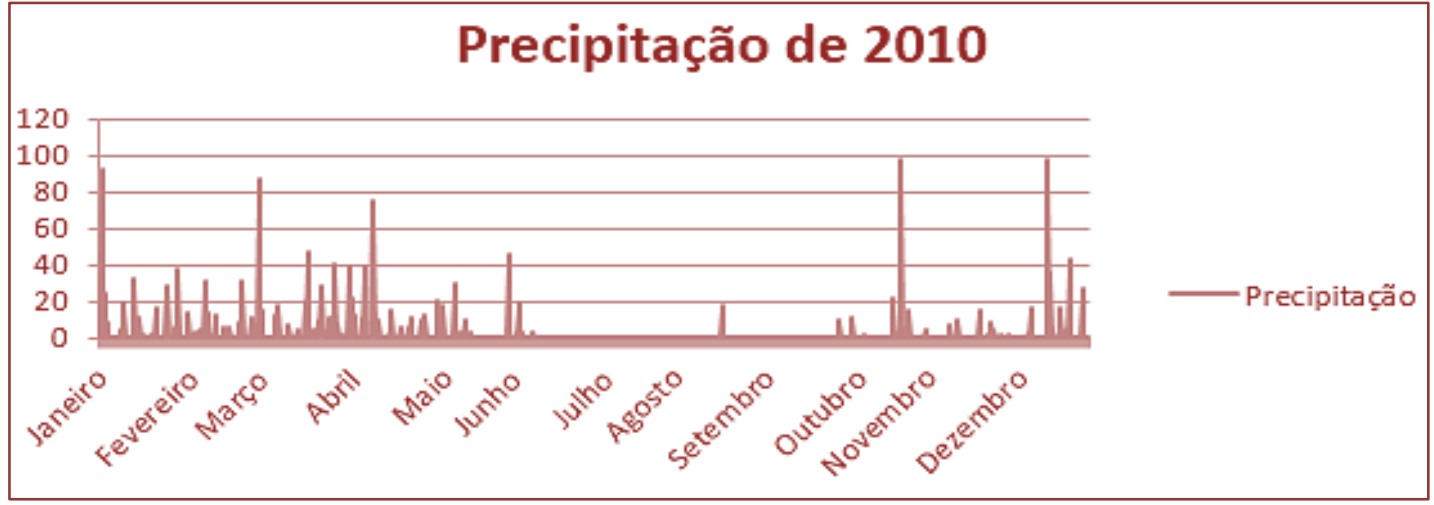

Fonte: INMET.

Em 2010 os índices pluviométricos foram bem dispersos, ficando os meses de novembro com 96 $\mathrm{mm} /$ dia e de dezembro com $98 \mathrm{~mm} /$ dia.

Figura 06: Meses com dados de precipitação do ano de 2011.

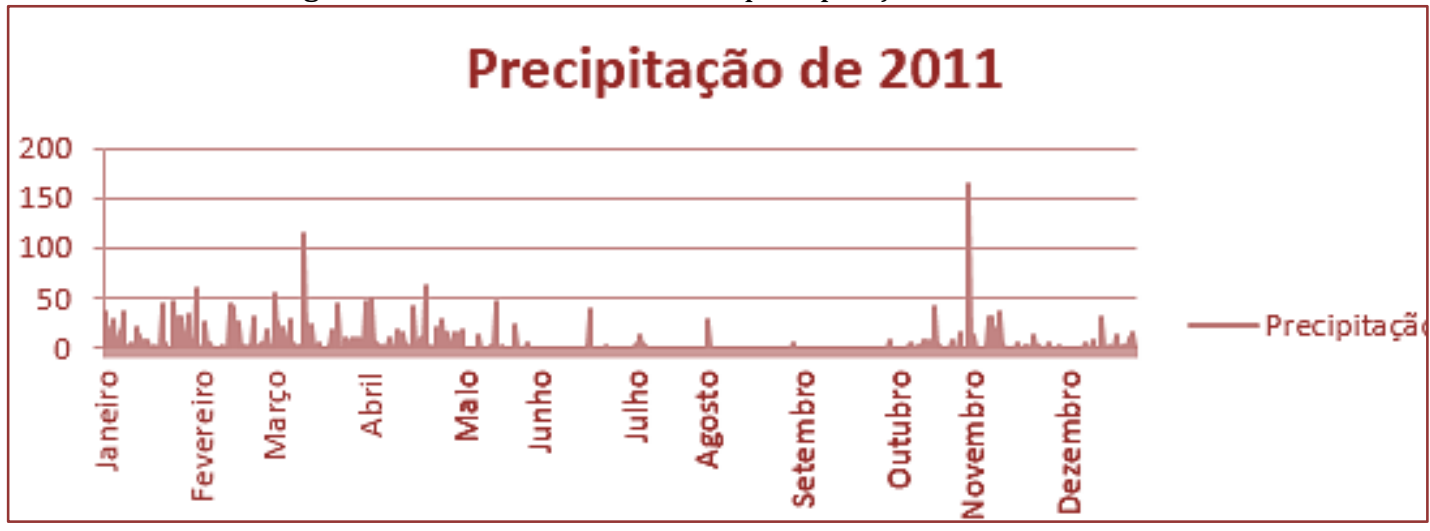

Fonte: INMET. 
Em 2011 a média de precipitação ficou entre 50 e $60 \mathrm{~mm} /$ dia, ficando os meses de março, com 70 $\mathrm{mm} /$ dia, e novembro com $160 \mathrm{~mm} /$ dia, com os maiores índices de precipitação.

Figura 07: Meses com dados de precipitação do ano de 2012.

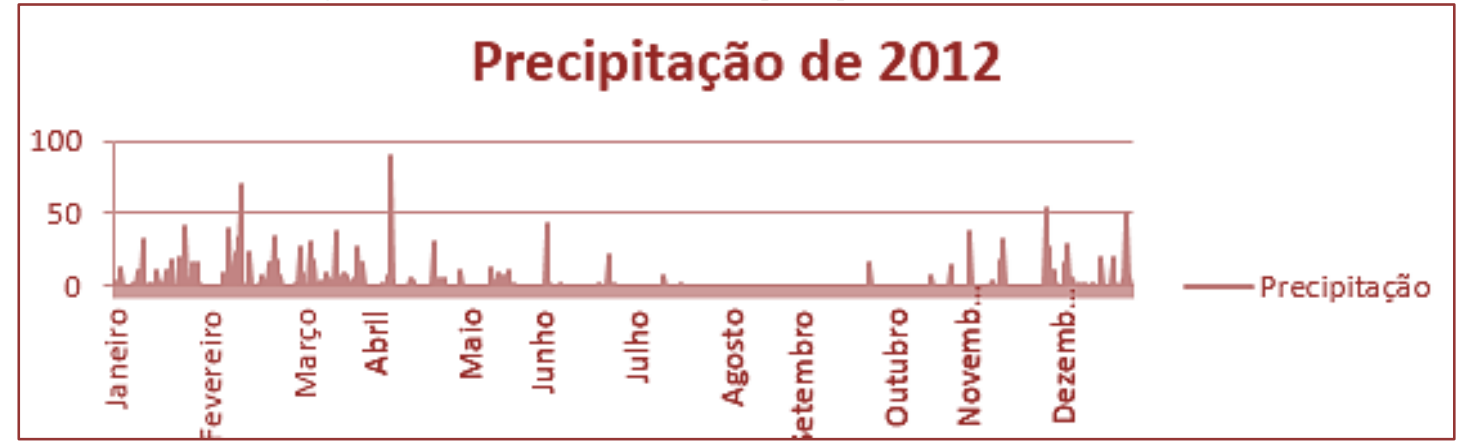

Fonte: INMET.

Em 2012 as maiores médias ficaram com os meses de fevereiro e abril, ficando com 81 e 94 $\mathrm{mm} / \mathrm{dia}$, respectivamente.

Figura 08: Meses com dados de precipitação do ano de 2013.

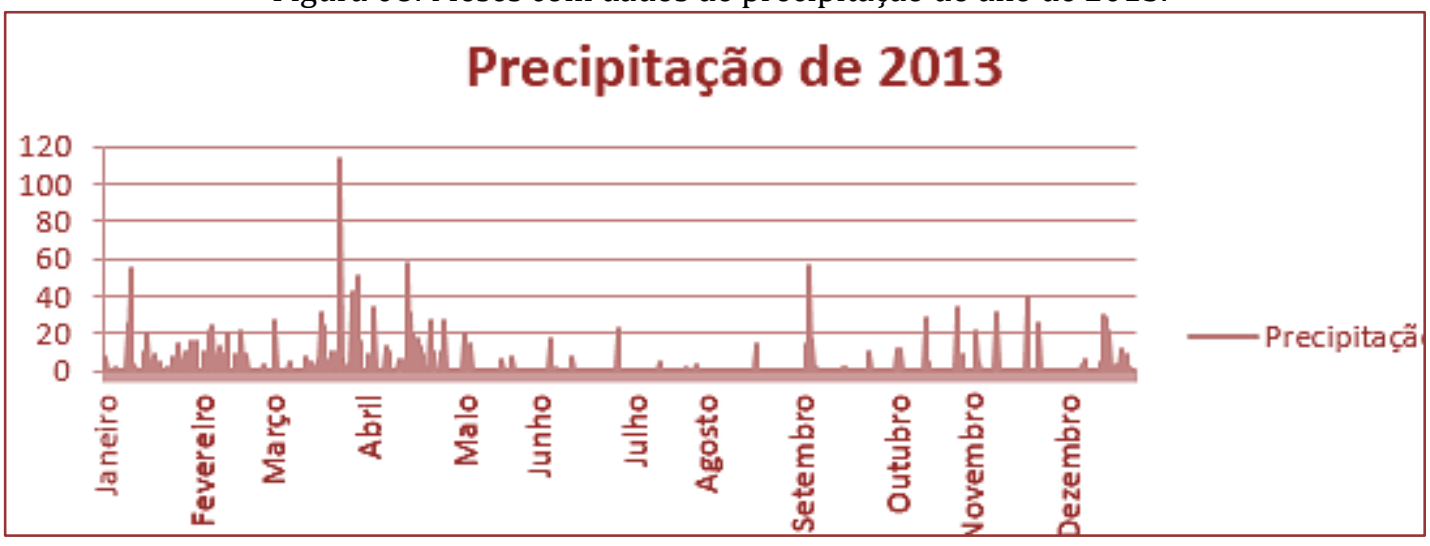

Fonte: INMET.

Em 2013 a média ficou entre 30 e 40mm/dia, somente no mês de abril que a precipitação chegou a $117 \mathrm{~mm} /$ dia.

Figura 09: Meses com dados de precipitação do ano de 2014.

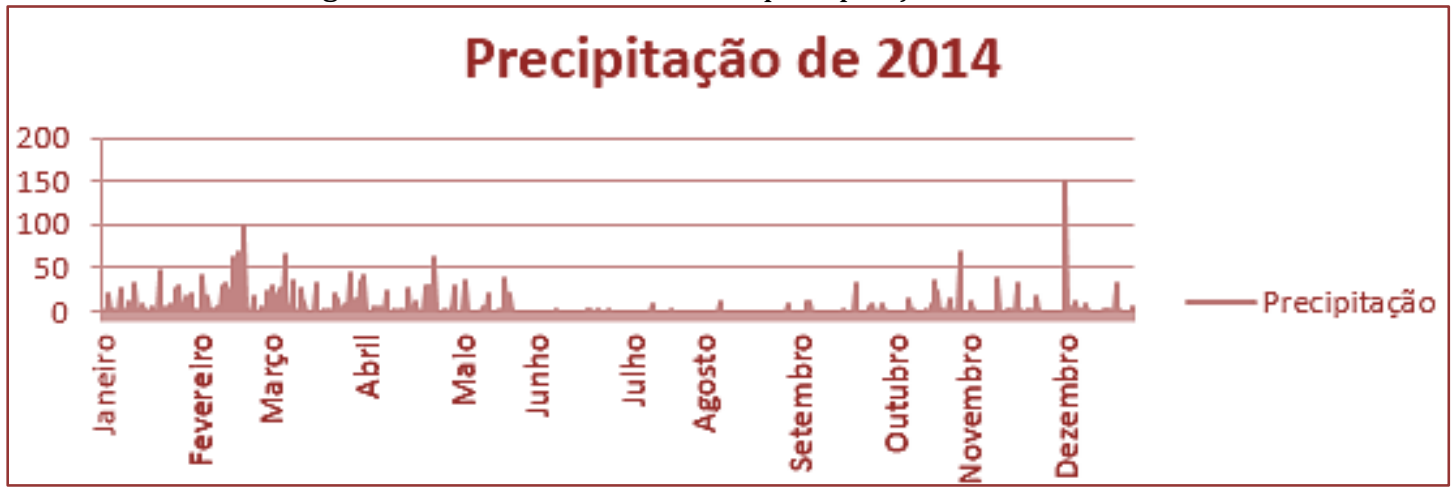

Fonte: INMET. 
Em 2014, a precipitação média ficou na casa dos 50 e $60 \mathrm{~mm} /$ dia, chegando a $150 \mathrm{~mm} /$ dia somente em dezembro.

Figura 10: Meses com dados de precipitação do ano de 2015.

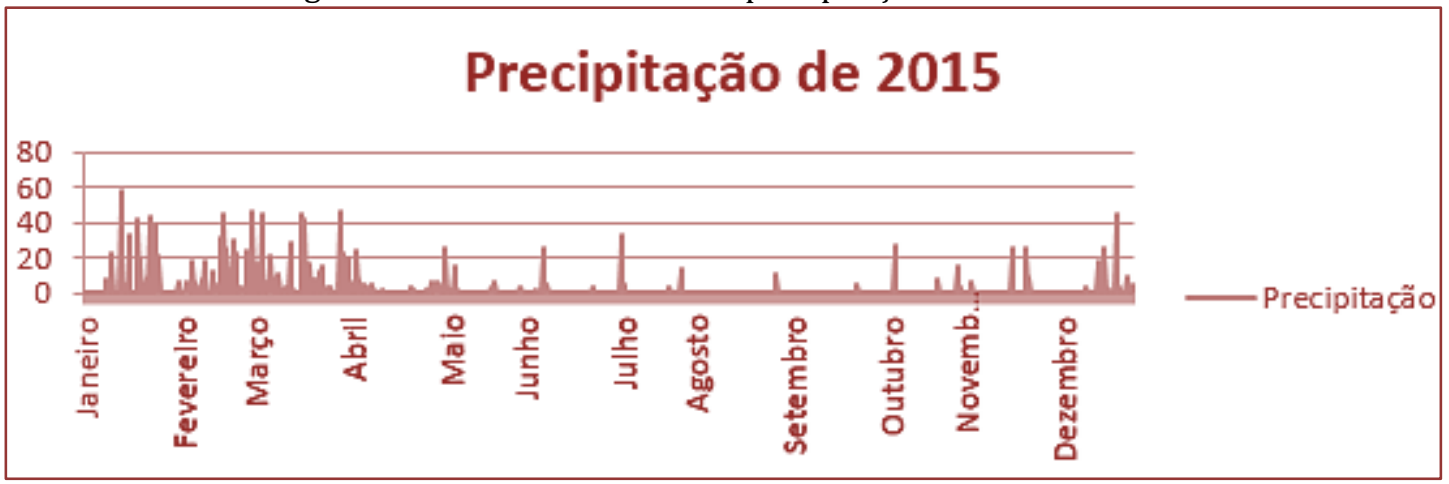

Fonte: INMET.

Em 2015, as médias ficarem entre 40 e $50 \mathrm{~mm} / \mathrm{dia}$, chegando a $60 \mathrm{~mm} / \mathrm{dia}$ somente no mês de janeiro.

Figura 11: Meses com dados de precipitação do ano de 2016.

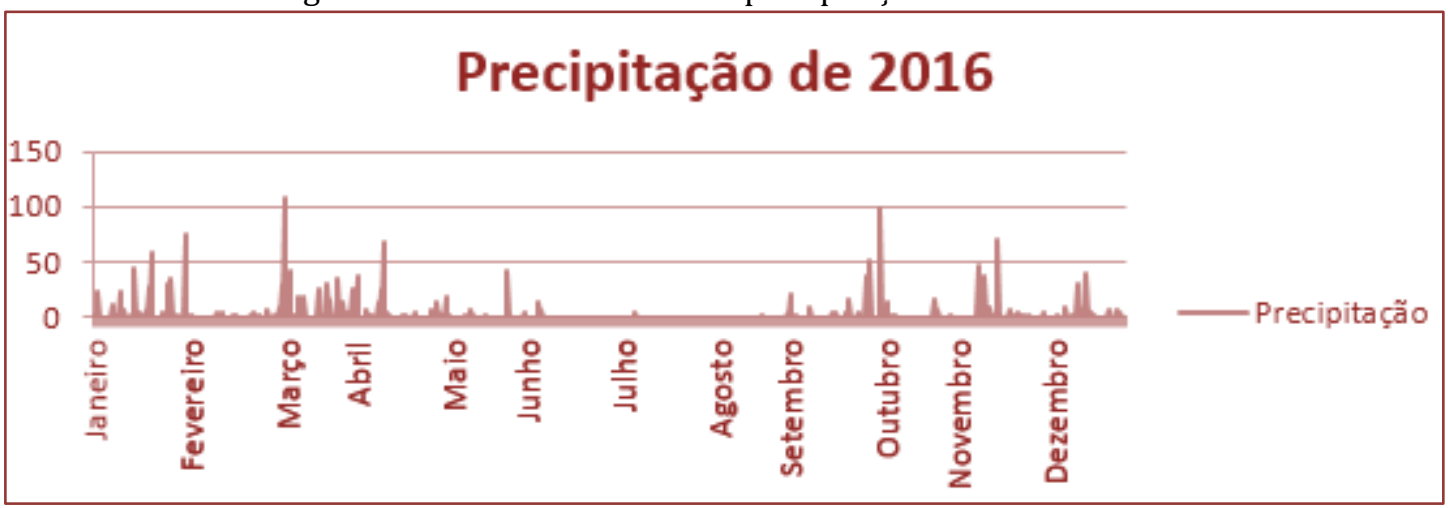

Fonte: INMET.

Em 2016, a média ficou na base dos $50 \mathrm{~mm} /$ dia, ficando o mês de março com $110 \mathrm{~mm} /$ dia, e o mês de outubro com $100 \mathrm{~mm} /$ dia, com os maiores índices de precipitação.

Figura 12: Meses com dados de precipitação do ano de 2017.

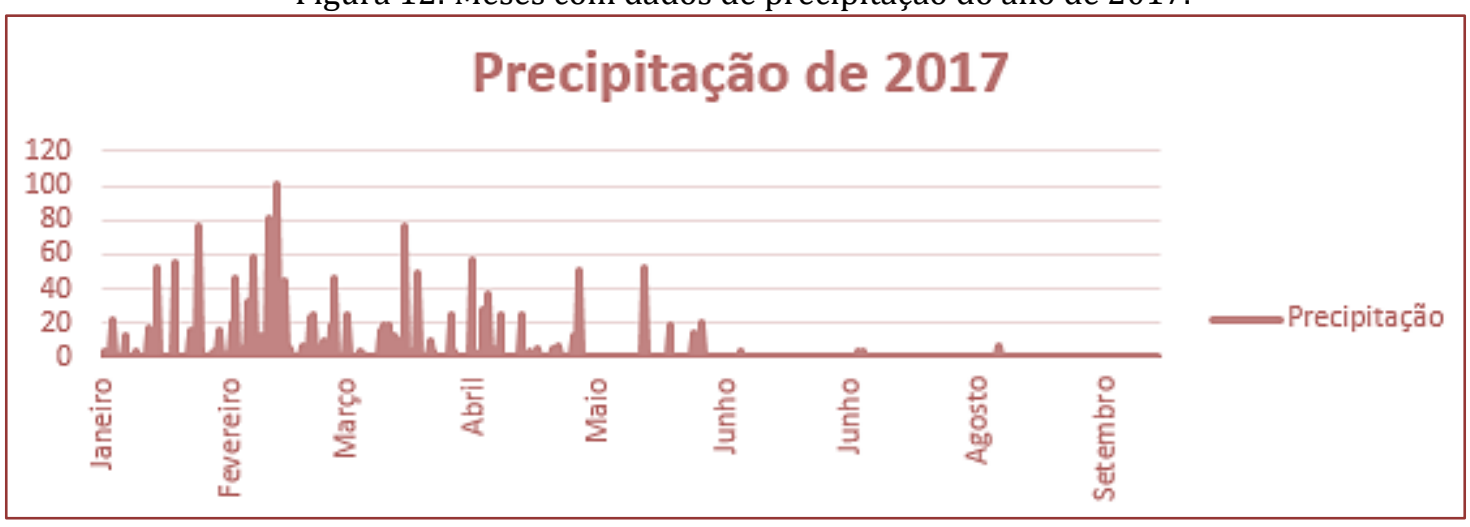

Fonte: INMET

Em 2017, até o presente momento, a média está entre 40 e $60 \mathrm{~mm} /$ dia, ficando janeiro com 80 $\mathrm{mm} /$ dia, e fevereiro com $103 \mathrm{~mm} /$ dia, como os meses de maior precipitação. 
Conforme mostrado nos gráficos, os maiores índices de precipitação estão nos anos de 2008 e 2011. O qual no ano de 2008 houve a maior cheia desse período, com a precipitação média chegando a 153 mm no mês de fevereiro. Os mapas pluviométricos a seguir mostram essa dispersão das chuvas no perímetro urbano de Marabá-PA, levando em consideração esses dois principais anos, 2008 e 2011.

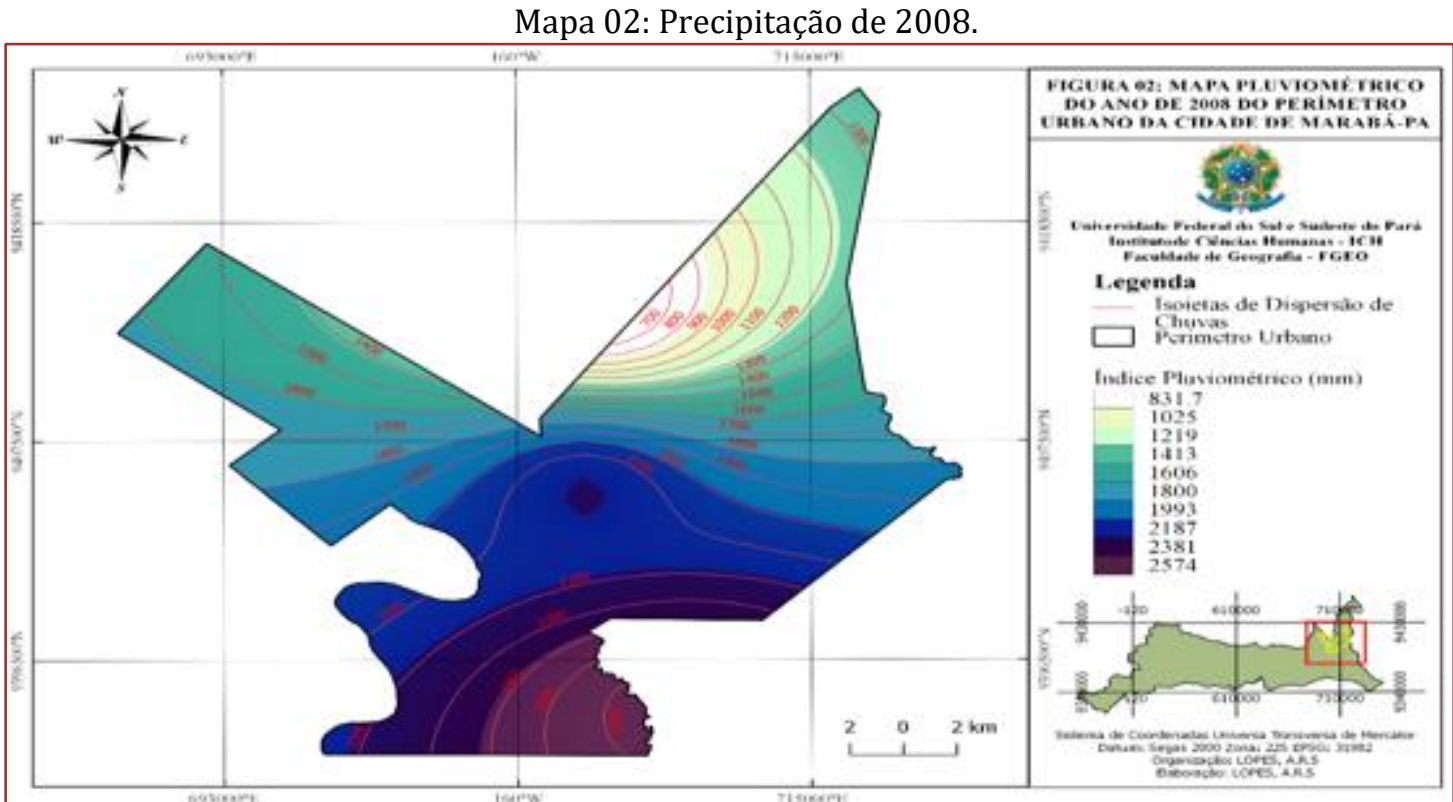

Fonte: IBGE (2010) - Instituto Nacional de Meteorologia (INMET, 2008) - Agência Nacional de Águas (ANA, 2008). Elaboração: LOPES, A.R.S.

Mapa 03: Precipitação de 2011.

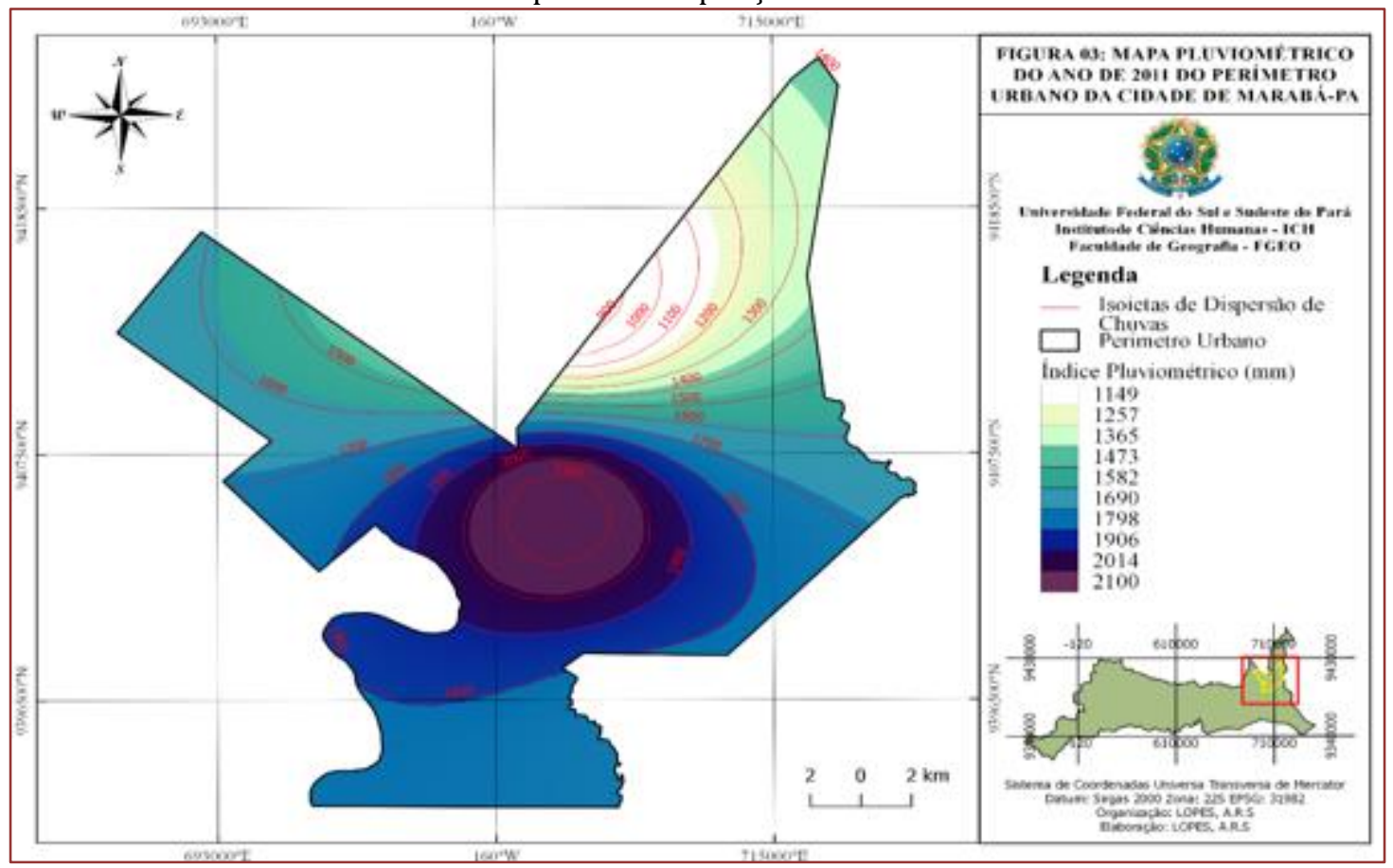

Fonte: IBGE (2010) - Instituto Nacional de Meteorologia (INMET, 2011) - Agência Nacional de Águas (ANA, 2011). Elaboração: LOPES, A.R.S.

No ano de 2008, o rio atingiu a cota de 11,5 metros, considerada crítica, tanto que a Defesa Civil informou que poderia declarar estado de emergência caso o rio aumentasse mais $10 \mathrm{~cm}$. A 
Prefeitura solicitou o apoio do Exército Brasileiro, e em conjunto com a Defesa Civil e Corpo de Bombeiros, organizaram uma força tarefa para o remanejo da população.

Como presente nos gráficos, os meses de maior ocorrência de chuvas estão entre dezembro e abril, e levando em consideração os dados de temperatura máxima e umidade relativa do ar dos mesmos meses citados, podemos fazer uma comparação com relação a proliferação da dengue.

Como já é de conhecimento das autoridades de saúde, o mosquito do dengue (Aedes aegypti), tem uma maior incidência de proliferação quando há água e sol em abundância. Nessas condições o ciclo evolutivo do mosquito diminui para até 8 dias, e no período mais frio esse ciclo é de 22 dias (FIOCRUZ, 2013). Dessa forma, podemos analisar um gráfico comparativo, a fim de verificar em quais meses do ano os índices pluviométricos e a temperatura máxima estarão em alta.

Figura 13: Dados comparativos de temperatura máxima e precipitação.

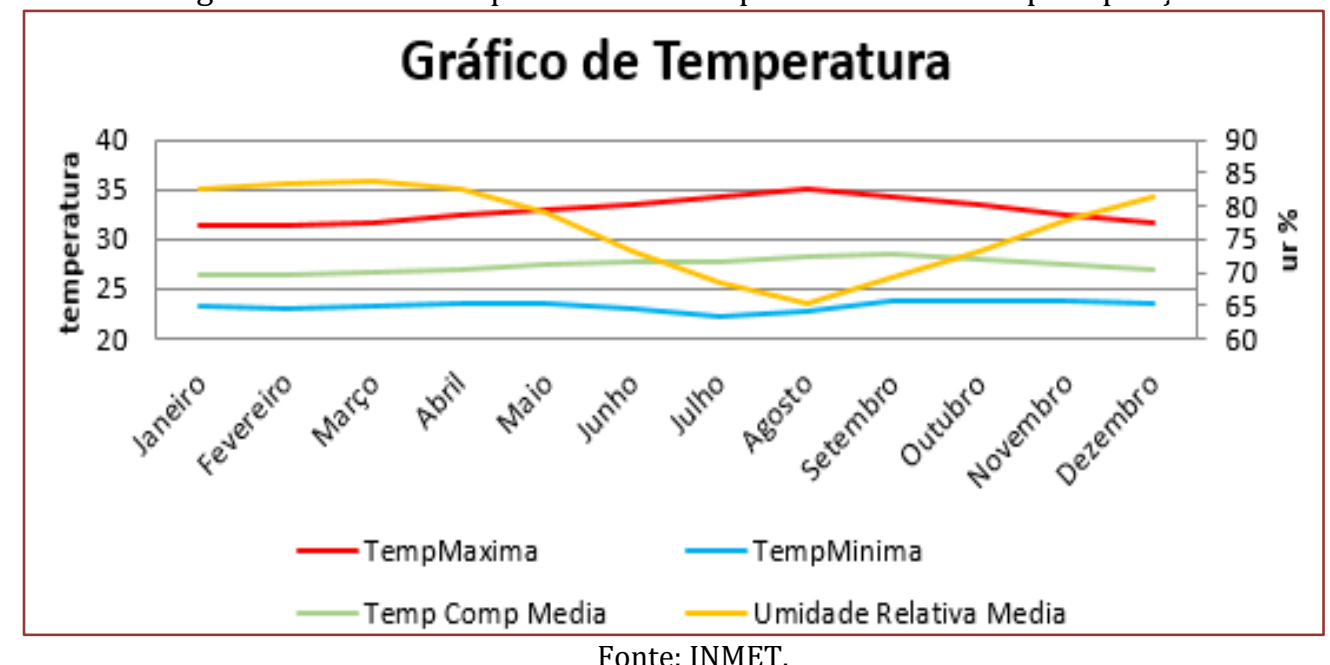

Pode-se perceber que o período em que a temperatura máxima e a umidade relativa do ar estão praticamente equiparadas são os mesmos meses de maior ocorrência de chuvas, e posteriormente, os meses de maior incidência de casos de dengue, como mostrado no gráfico a seguir.

Figura 14: Tabela de casos registrados no município no período de 2007 a 2012.

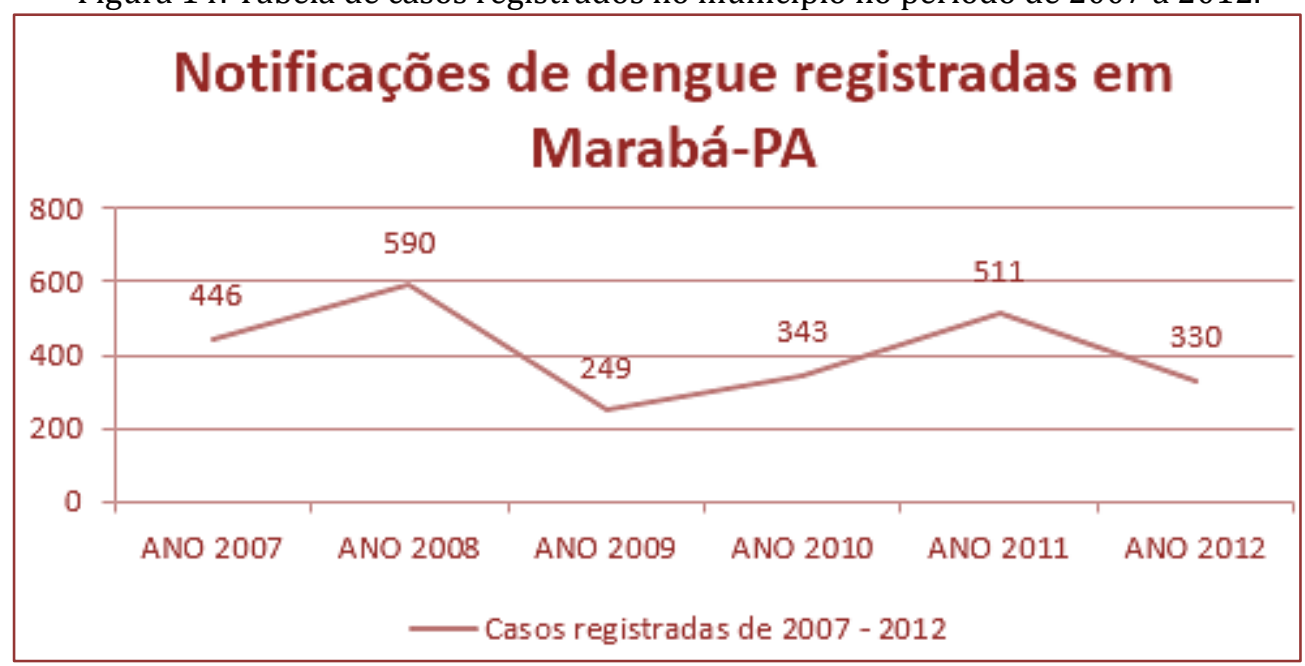

Fonte: Prefeitura de Marabá-PA - IBGE Cidades.

A partir desse gráfico podemos ter uma compreensão de que nos anos em que houve as cheias mais severas, 2008 e 2011, são os mesmos em que a ocorrência de dengue registradas foram maiores. 
Ou seja, isso faz com que o clima seja um contribuinte fundamental para o aumento da endemia. Sabe-se que o fator climático é um dos fenômenos que contribuem para essa proliferação, porém há outros como desmatamento, falta de saneamento básico, impossibilidade de acesso aos serviços públicos de saúde, resíduos sólidos, falta de informação da população, efetivo reduzido de profissionais de combate a endemia, entre outros fatores.

\section{CONCLUSÕES}

Conclui-se que, a proliferação do mosquito Aedes aegypti está diretamente ligado com o clima, pois, como mostrados nos gráficos, nos meses de maior ocorrência que são de dezembro a abril, é o mesmo período em que o número de notificações de casos de dengue registradas também cresce. A prefeitura faz mutirões de combate ao mosquito com agentes de endemias visitando as casas, propagandas televisivas a fim de conscientizar a população, e em alguns bairros mais endêmicos utilizam o carro de fumaça, ou seja, nesse período há um grande aparato para que essa endemia não se alastre.

Contudo, há dificuldades no combate à doença devido as problemáticas relacionadas a habitações, tais como, limitado acesso aos serviços urbanos básicos de abastecimento de água, tratamento de esgoto, coleta de resíduos sólidos e drenagem de águas pluviais (SEGURADO et al., 2016). Entendese assim que o combate a essa endemia é de extrema necessidade, devido ser de fácil proliferação e alto grau de contaminação. E, mesmo com todos esses fatores exógenos que favorecem ainda mais a proliferação dessa endemia, o clima continua sendo um forte agente propulsor para o surgimento do mosquito, e consequentemente, da doença.

\section{REFERÊNCIAS}

[1] — Instituto Brasileiro de Geografia e Estatística (IBGE) - Dados municipais de endemias. http://www.cidades.ibge.gov.br/painel/saude.

[2] _— Ministério da Saúde (MS) - http://portalsaude.saude.gov.br/:

[3] — Instituto Nacional de Meteorologia (INMET). Dados meteorológicos municipais http://www.inmet.gov.br/portal/index.php?r=bdmep/bdmep. [4] Ministério da Saúde, Departamento de Informática do Sistema Único de Saúde - Datasus 2011.
em: Disponível <https://cidades.ibge.gov.br/brasil/pa/maraba/pesquisa/42/30280?tipo=cartograma\&ano=2011>.

[5] Almeida, J.J: OS Riscos Naturais e a História: O Caso Das enchentes em Marabá (PA). Tempos Históricos, Volume 15 - 2o Semestre - 2011 - p. 205 - 238 ISSN 1517-4689.

[6] Júnior, A.P; Oliveira, G.P; Maia, J.O - Fatores Ambientais (LIXO), Climáticos (Chuva) e a Evolução da dengue E malária: o Caso da Praça São Francisco, Cidade Nova, Marabá - PA. Enciclopédia Biosfera, Centro Científico Conhecer - Goiânia, Doi: 10.18677/EnciBio_2017A128, 2017.

[7] Câmara, F.P; Gomes, A.F; Santos, G.T e Câmara, D.C.P - Clima e epidemias de dengue no Estado do Rio de Janeiro, Revista da Sociedade Brasileira de Medicina Tropical 42(2):137-140, mar-abr, 2009.

[8] Ribeiro, Laércio. Águas Amargas - Revista Foco, Marabá-PA, Ano I, maio/jun no 5, 2009. P. 36 - 41.

[9] Jornal Correio do Tocantins - https://www.reporterdiario.com.br/noticia/15592/chuva-deixa-10mil-moradores-desalojados-no-para/.

[10] Seguraro, A. C.; Cassenote, A. J.; Luna, E. A. Saúde nas metrópoles -doenças infecciosas. Estudos Avançados, v. 30, n. 86, p. 29-49, 2016. Disponívelem: <http://dx.doi.org/10.1590/S010340142016.00100003>. DOI: 10.1590/S0103-40142016.00100003. 


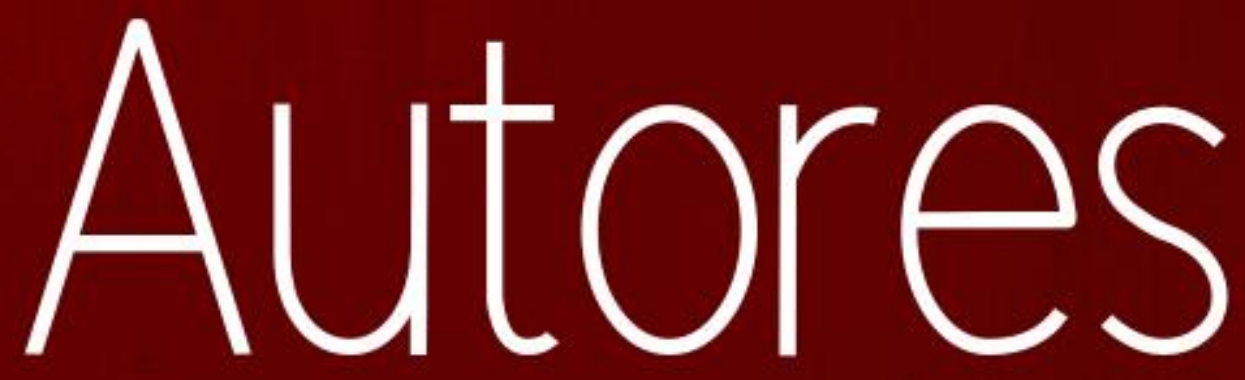




\section{FABIANE DOS SANTOS TOLEDO (Organizadora)}

Mestre em geografia pela Universidade Federal de Uberlândia, na área de planejamento ambiental, atuante em geociências, com ênfase em ambiental - áreas verdes, índice de áreas verdes, espaços públicos livres e parques urbanos. Possui graduação em Geografia (Licenciatura e Bacharelado) pela Universidade Federal de Uberlândia, mestrado em geografia pela Universidade Federal de Uberlândia. Tem experiência na área de Geociências, com ênfase em Geografia ambiental, atuando principalmente nos seguintes temas: áreas verdes, índice de áreas verdes, espaços públicos livres e parques urbanos.

\section{ADEILDO CABRAL DA SILVA}

Professor do Instituto Federal do Ceará, Campus Fortaleza. Geografo pela Universidade Federal da Paraíba (UFPB), Mestre e doutor em Ciências da Engenharia Ambiental pela Escola de Engenharia de São Carlos - Universidade de São Paulo (USP) e Pós-doutorado (2015) na Faculdade de Engenharia da Universidade do Porto (FEUP). Coordenador do Laboratório de Energias Renováveis e Conforto Ambiental - IFCE Fortaleza.

\section{ALESSANDRA OLIVEIRA TELES}

Possui licenciatura em Geografia pela Universidade Estadual de Feira de Santana, mestrado em Geografia pela Universidade Federal da Bahia . Doutorado em Geografia pela Universidade Federal de Sergipe (2017). Professora Adjunto do Departamento de Ciências Humanas e Filosofia da Universidade Estadual de Feira de Santana. Participa do Grupo de Estudos e Pesquisa em Economia Popular e Solidária e Desenvolvimento Local (GEPOSDEL) e da Incubadora de Iniciativas da Economia Popular e Solidária (IEPS/UEFS).

\section{ALINE SOARES DA SILVA}

Bacharelanda em Geografia pela Universidade Federal do Rio Grande do Norte, campus Caicó. Bolsista de Apoio Administrativo e Técnico do Núcleo de Prática Jurídica - NPJ do CERES/UFRN.

\section{ANTONIO JORGE BARBOSA DA SILVA}

Possui Bacharelado em Direito pelo Centro Universitário do Norte (2005). Pós-graduação em Direito Penal e Processual pela Universidade federal do Amazonas (2007). Pós-graduação em Segurança Pública e Inteligência Policial pela Universidade de Cuiabá (2012). Mestrado em Gestão de Áreas Protegidas na Amazônia pelo Instituto Nacional de Pesquisas da Amazônia(2018). Policial Militar do Amazonas. Exerceu atividades de Professor de Direito Ambiental e Legislação (2006). Diretor Geral do Complexo Penitenciário Anísio Jobim (2000). Diretor da Guarda Civil Metropolitana de Manaus (2006). Consultor e Instrutor Credenciado do SEBRAE na área de Legislação, Licitação e Contratos Administrativos (2007). Gerente de Administração e Finanças da Secretaria Municipal de Meio Ambiente e Sustentabilidade (2008). Comandante da Guarda Municipal de Itacoatiara/Am (2011).

\section{ARTUR ISMAEL VIANA DE MEDEIROS}

Licenciado em Geografia pela Universidade Federal do Rio Grande do Norte (UFRN) - Centro de Ensino Superior do Seridó (CERES - Caicó). Possui experiência na área de Geografia, com ênfase no Ensino de Geografia e em Climatologia.

\section{ATHOS RICARDO SOUZA LOPES}

Graduando do Curso de Geografia Bacharelado pela Universidade Federal do Sul e Sudeste do Pará - UNIFESSPA. Conhecimento técnico na área de Cartografia Básica, Cartografia Temática e Sensoriamento Remoto, no qual foi monitor em todas estas disciplinas. Assíduo nas pesquisas voltadas para o geoprocessamento com ênfase em análise do solo, delimitação de bacias hidrográficas, processamento de imagens de satélite, análise de dados quantitativos e qualitativos 
e dados primários e secundários e análise de poços e água superficial, tendo como foco a Geociência e suas aplicabilidades.

\section{CRISTIAN ORLANDO AVILA QUIÑONES}

Doutorando em Desenvolvimento Regional pela Universidade Federal do Tocantins, Mestre em Ciências Econômicas pela Universidade Nacional de Colômbia - UNAL, Economista pela Universidade Pedagógica e Tecnológica de Colômbia - UPTC. Professor dos cursos de Administração e Economia (ECACEN/UNAD) Universidade Nacional Aberta e a Distancia-UNAD. Área de Pesquisa: Desenvolvimento Regional, Desenvolvimento Econômico; Corrupção; Análise Regional e, Economia do Tocantins.

\section{CRISTIANO SAULO DE MORAIS}

Técnico Agrícola-EAJ(UFRN), Graduando em Geografia - Bacharelado. Pela Universidade Federal do Rio Grande do Norte, campus Caicó. Bolsista de extensão FAEX. Vinculado ao Laboratório de Hidrografia, Climatologia e Cartografia (LAHICC), com afinidade voltada para hidrografia e climatologia.

\section{CRISTOVÃO GOMES}

Graduado em Tecnologia em Gestão Ambiental pelo Instituto Federal do Ceará (IFCE). Cursando Técnico em Edificações pelo IFCE Fortaleza. Pesquisador do Laboratório de Energias Renováveis e Conforto Ambiental (LERCA -IFCE).

\section{DUARTE,ISADORA}

Graduando no Instituto Federal do Rio Grande do Norte

\section{GUILHERMINO,SIBELE}

Graduanda na Universidade Estadual da Paraíba

\section{GUSTAVO DA SILVA}

Possui graduação Bacharelado em Geografia pela Universidade Federal de Mato Grosso do Sul (2005) e mestrado em Geografia pela Universidade Federal de Mato Grosso do Sul (2007). Foi Diretor do Departamento de Meio Ambiente e Coordenador Municipal de planejamento Urbano, Rural e Meio Ambiente da Prefeitura Municipal de Anastácio-MS. Trabalhou no Departamento de Projetos da empresa \&quot;COESO\&quot; ? Cooperativa de Energia e Desenvolvimento Rural do Sudoeste Sulmatogrossense. Atualmente é professor efetivo da Universidade Federal do Sul e Sudeste do Pará do Curso de Geografia.Tem experiência na área de Geociências, com ênfase em Geografia Física, atuando principalmente nos seguintes temas: Cartografia, Sensoriamento Remoto, Topografia e Análise de Bacias Hidrográficas.

\section{JAMILLY LEITE DIAS}

Possui título de Bacharel em Meteorologia pela Universidade Federal do Pará - UFPA, Mestrado em Meteorologia pela Universidade Federal de Campina Grande - UFCG, Graduanda no curso de Licenciatura em Geografia pela Universidade Estadual da Paraíba (em andamento). Tem experiência na área de Geociências, com ênfase em Meteorologia, Agrometeorologia, Climatologia e Extremos Meteorológicos de Tempo e Clima. Atualmente está atuando no seguinte tema: Monitoramento da Zona de Convergência Intertropical sobre o Oceano Atlântico tropical. 


\section{JANIEL LOPES DE OLIVEIRA}

Possui graduação em Geografia pela Universidade Federal do Triângulo Mineiro (2014), Pósgraduado em Saneamento Ambiental pelo Instituto Federal de Educação, Ciência e Tecnologia do Triângulo Mineiro (2016). Mestrando em Geografia pela Universidade Federal de Uberlândia, área de concentração: Geografia e Gestão do Território, linha de pesquisa: Análise, Planejamento e Gestão Ambiental/Geoprocessamento. Trabalhou como Analista Ambiental em Empresa do setor sucroenergético, tem experiência na área de Geografia com ênfase em Gestão, Análise e Planejamento Ambiental.

\section{JOSÉ IVALDO BARBOSA DE BRITO}

Possui graduação em Meteorologia pela Universidade Federal da Paraíba, mestrado em Meteorologia pelo Instituto Nacional de Pesquisas Espaciais e doutorado em Recursos Naturais pela Universidade Federal da Paraíba. Atualmente é Professor Associado da Universidade Federal de Campina Grande. Tem experiência nas áreas de Ciências Ambientais e Geociências, com ênfase em Meteorologia e Climatologia. Atuando principalmente nos seguintes temas: Desertificação; Variabilidade climática; Recursos hídricos, Índices de detecção e monitoramento de mudanças climáticas regionais e globais, Oscilações climáticas interanuais e interdecenais; Estudos climáticos das regiões Norte, Nordeste, Centro-Oeste, Sudeste e Sul do Brasil.

\section{JULIANO MOREIRA DO NASCIMENTO}

Professor de Geografia do Ensino Fundamental II / Médio no Ação Colégio e Curso e na Escola José de Paiva Gadelha/SESI/EBEP; Atuou como professor na Faculdade de Desenvolvimento e Integração Regional/Pós-Graduação - FADIRE e na Faculdade São Francisco - FSM; Mestre em Geografia pelo Programa de Pós-Graduação em Geografia da Universidade Federal da Paraíba; Graduado em Licenciatura Plena em Geografia, pela Universidade Federal de Campina Grande; Atividades anteriores: Coordenador/Professor Comunitário na EMEIEF José Antonio Dias (2011); Membro da Secretaria Executiva do Meio Ambiente de Cajazeiras/SEMAC, na função de técnico ambiental (2011); Bolsista pelo Programa de Bolsas da CAPES, 2009.2; Membro do Conselho Editorial da revista OKARA: Geografia em debate, do Programa de Pós-graduação em Geografia da Universidade Federal da Paraíba. URL:www.okara.ufpb.br; Conselheiro do Conselho Pleno da UFCG; Experiência na área de Geografia, atuando principalmente nos seguintes campos: ensino de geografia, geografia agrária, movimentos sociais no campo, educação do/no campo, meio ambiente, cidadania, sustentabilidade, agricultura familiar, políticas públicas e educação popular.

\section{MARCELE LIMA DE OLIVEIRA}

Graduada no Curso de Licenciatura Plena em Geografia pela Universidade Estadual de Paraíba, Campus III - localizado em Guarabira. Tem experiência na área de Geografia, com ênfase em Geografia Cultural e Geografia Política/Geopolítica. Atualmente, faz parte do Grupo de Pesquisa Olhares Geográficos - Grupo de Pesquisa em Geografia Cultural e da Percepção, nas linhas de pesquisa: Geografia, Território e paisagens e Geografia Cultural e da Percepção.

\section{MARIA ALETHEIA STEDILE BELIZÁRIO}

Licenciada e Bacharel em Geografia pela Universidade Estadual do Ceará (1997 e 1999) e Mestre em Geografia pela Universidade Estadual do Ceará (2002). Professora efetiva do Departamento de Geografia da Universidade Estadual da Paraíba. Na graduação ministra as disciplinas Região e Regionalização e Geografia Cultural, na pós-graduação leciona a disciplina de Geografia, Turismo e Desenvolvimento Local Sustentável no curso de Especialização em Geografia e Território da Universidade Estadual da Paraíba. Tem experiência na área de Geografia, com ênfase em Geografia Cultural, atuando principalmente nos seguintes temas: geografia urbana e regional, geografia da religião. Presidente do Núcleo Docente Estruturante - NDE do Curso de Geografia da Universidade Estadual da Paraíba-UEPB. 


\section{MARIA CRISTINA CAMPOS RIBEIRO}

Mestre em Ciências Sociais e Humanidades - TECCER/UEG, Professora de Artes na Educação Básica da Secretaria de Educação e Cultura de Goiás

\section{MARIA IDELMA VIEIRA D' ABADIA}

Doutora em Geografia-UFG, Professora de Geografia e do Programa de Mestrado em Territórios e Expressões Culturais no Cerrado - TECCER da Universidade Estadual de Goiás/ UEG

\section{MARLEY TRAJANO LIMA}

Graduando do Curso de Geografia em Licenciatura pela Universidade Federal do Sul e Sudeste do Pará - UNIFESSPA. Bolsista do projeto de pesquisa PAPIM, intitulado: Proposta Pedagógica aos Modelos Geográficos Projetados pelo SARNDBOX. Atuante nas pesquisas de planejamento ambiental com foco no processo Geossitêmico, e com especialidade em Geoprocessamento. Professor voluntário do projeto social cursinho popular Avante, promovido pela Universidade do Estado do Pará, Campus VIII/Marabá.

\section{MICHAEL LIMA SILVA}

Graduado em Tecnologia em Gestão Ambiental pelo Instituto Federal do Ceará (IFCE). Cursando Técnico em Edificações pelo IFCE Fortaleza. Pesquisador do Laboratório de Energias Renováveis e Conforto Ambiental (LERCA -IFCE). Servidor do Instituto Brasileiro de Geografia e Estatística (IBGE), Unidade Estadual Ceará - Gerência de Geodésia e Cartografia (GGC).

\section{NILTON MARQUES DE OLIVEIRA}

Doutor em Desenvolvimento Regional e Agronegócio pela Universidade Estadual do Oeste do Paraná - UNIOESTE, Toledo - PR. Mestre em Economia Aplicada pela Universidade Federal de Viçosa - UFV, Economista pela Universidade Estadual de Maringá - UEM. Professor do Programa de Pós-graduação em Desenvolvimento Regional (PGDR/UFT) e do curso de Ciências Econômica da Universidade Federal do Tocantins . Vice-presidente do Instituto Territorial do Centro Norte Brasileiro (IT Centro Norte/ PGDR-UFT). Membro do comitê técnico científico (PIBIC - CNPq/UFT). Integrante do Banco de Avaliadores do Sistema Nacional de Avaliação da Educação Superior BASis-Inep/Mec. Tutor do Grupo PET de Ciências Econômicas da UFT. Líder do Grupo de pesquisa em Desenvolvimento Regional e Territorial do Centro Norte do Brasil - DRT Centro Norte ( $\mathrm{CNPq}$ /UFT). Área de Pesquisa: Desenvolvimento Regional, Territorial e Local; Economia Regional e Urbana; Análise Regional e, Economia do Tocantins.

\section{PAULO DANIEL CURTI DE ALMEIDA}

Possui graduação (Licenciatura Plena e Bacharelado) em Geografia pela Universidade Federal de Mato Grosso (2009) e mestrado em Geografia pela Universidade Federal de Mato Grosso (2011). Atua na área de Geografia, com ênfase em ensino de Geografia e Geografia Urbana, atuando principalmente nos seguintes temas: produção do espaço urbano, reestruturação urbana e especulação imobiliária. É professor de Educação Básica, Técnica e Tecnológica do Instituto Federal de Educação, Ciência e Tecnologia de Mato Grosso - campus Pontes e Lacerda/Fronteira Oeste.

\section{RAILA MARIZ FARIA}

Possui graduação em Geografia-Licenciatura pela Universidade Federal do Rio Grande do Norte (2018). Atualmente graduanda do Bacharelado em Geografia pela Universidade Federal do Rio Grande do Norte. Bolsista de extensão FAEX . Vinculada ao Laboratório de Hidrografia, Climatologia e Cartografia (LAHICC). Tem experiência na área de Geografia, com ênfase em Ensino, Cartografia e Geoprocessamento. 


\section{RAIMUNDO WILSON PEREIRA DOS SANTOS}

Possui doutorado em Geografia pela Universidade Federal de Minas Gerais - UFMG / Instituto de Geociências - IGC (2013), mestrado em Desenvolvimento e Meio Ambiente pela Universidade Federal do Piauí (2005), especialização em Ciências Ambientais pela UFPI (2001) e graduação em Licenciatura Plena em Geografia pela Universidade Federal do Piauí (2000). Possui os cursos técnicos de Administração (1984) e Contabilidade (1986) pelo Instituto Federal de Educação, Ciência e Tecnologia do Piauí. Atualmente é professor da Universidade Federal do Piauí no curso de Geografia, coordena o curso de licenciatura em Geografia à Distância (EaD/UFPI). Tem experiência na área de educação e pesquisa, atuando principalmente nos seguintes temas: Geografia Agrária, Desenvolvimento Territorial Rural Sustentável, Agricultura Familiar e Camponesa, Meio Ambiente e Educação Ambiental.

\section{REBECCA LUNA LUCENA}

Geógrafa, com graduação pela Universidade Federal da Paraíba, Bacharelado e Licenciatura (UFPB 2006). Mestre em Desenvolvimento e Meio Ambiente pelo Prodema (UFPB/UEPB 2008) e Doutora em Geografia pela Universidade de Brasília, com especialidade na área de estudos teóricos e aplicados em Climatologia Geográfica (UnB 2016). Professora de Geografia Física da Universidade Federal do Rio Grande do Norte CERES/UFRN. Coordenadora do Laboratório de Hidrografia, Climatologia e Cartografia (LAHICC) da UFRN.

\section{SHARLENE BERNARDINO DA SILVA}

Licenciada em Geografia pela Universidade Estadual da Paraíba-UEPB, (2009). Mestre em Geografia pela Universidade Federal da Paraíba-UFPB, (2015). Atuou como Professora substituta do departamento de Geografia, (UEPB) 2016-2018. Tem trabalhos publicados e orientação de TCC, nas seguintes áreas: geografia cultural, educação geográfica e geografia urbana. É professora efetiva do estado do Rio Grande do Norte, desde 2015.

\section{SILVANA ARAÚJO MACIEL}

Possui graduação em Licenciatura Plena em Geografia pela Universidade Estadual do Piauí (2008). Especialização em Docência no Ensino Superior - UESPI e Gerenciamento em Recursos Ambientais - IFPI. Foi professora do quadro provisório da Universidade Estadual do Piauí (UESPI) e professora formadora do Plano Nacional de Educação Básica -PARFOR-UESPI. Atualmente é professora do quadro permanente da Prefeitura Municipal de Piripiri, Piauí, professora do quadro provisório da Secretária de Educação do Estado do Piauí - SEDUC e mestranda do Programa de Pós-Graduação em Geografia - PPGGEO da Universidade Federal do Piauí -UFPI. Possui experiência nas áreas de Geografia e Ensino e Geografia e Meio Ambiente.

\section{SIMONE DA SILVA COSTA}

Possui graduação em Ciências Econômicas pela Universidade Federal do Rio Grande do Norte, Mestrado em Economia pela Universidade Federal da Paraíba e Doutorado em Arquitetura e Urbanismo pela Universidade Federal do Rio Grande do Norte na área de concentração: urbanização, projetos e política físico - territoriais. Atou 5 anos como tutora no Curso de Administração Pública à distância da Universidade Federal do Rio Grande do Norte (2011 - 2015) e 5 anos como professora substituta (presencial) na referida universidade. Tem experiência na área de Economia aplicada. Políticas públicas e Avaliação de Políticas Públicas, com ênfase nas políticas de habitação e políticas de desenvolvimento regional.

\section{THIAGO RAFAEL DA COSTA SANTOS}

Mestre em História pela UFMT e doutorando em Estética e História da Arte pela USP. Docente do IFMT, campus Pontes e Lacerda/Fronteira Oeste, atuando nas áreas de história, história da arte, história e filosofia da ciência. É autor de "O Brasil pitoresco de J.B. Debret ou Debret, artistaviajante" (RJ, 2016). 


\section{WAINESTEN CAMARGO}

Mestrando em Desenvolvimento Regional pela Universidade Federal do Tocantins e Bacharel em Direito por essa mesma instituição. Advogado inscrito na OAB. Compôs a equipe técnica da Comissão Especial de Estudos para o Novo Ordenamento Econômico, Administrativo, Social e Político do Tocantins (CENOVO), da Assembleia Legislativa do Tocantins. Participou do programa Jovens Talentos Para a Ciência, promovido pelo CNPq, e esteve vinculado durante toda a graduação ao PIBIC e à atividades de extensão. Em 2018, em atividade junto ao projeto de extensão Nós Propomos, teve projeto autoral de desenvolvimento social materializado, assim, foi concebido o Centro Comunitário Viver com Alegria, que atende população idosa na região sul de Palmas/TO. Atualmente é Professor Convidado dos cursos de Direito e Ciências Econômicas da Universidade Federal do Tocantins, onde desenvolve trabalhos interdisciplinares de pesquisa e extensão nas áreas de Direito e Economia.

\section{YGOR FELIPE TÁVORA DA SILVA}

Professor Efetivo do Instituto Federal de Ciência e Tecnologia do Amazonas; Professor Efetivo da Universidade do Estado do Amazonas - UEA; Doutor em Geografia pela Universidade Federal de Goiás - UFG; Mestre em Direito Ambiental pela Universidade do Estado do Amazonas - UEA; Mestre em Gestão de Áreas Protegidas da Amazônia - INPA; Graduado em Direito pela Universidade do Estado do Amazonas - UEA e em Administração pela Universidade Federal do Amazonas - UFAM. 


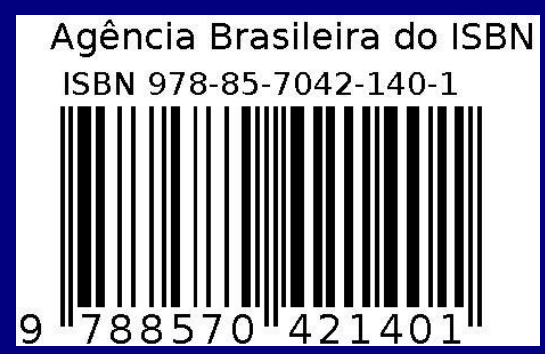

